\title{
DESENVOLVIMENTO DE UM EQUIPAMENTO PARA EXECUÇÃO DE ESTACAS HÉLICE SEGMENTADA
}

Dissertação apresentada à Escola de Engenharia de São Carlos, da Universidade de São Paulo, como parte dos requisitos para obtenção do título de Mestre em Engenharia Civil: Geotecnia.

ORIENTADOR: Prof. Dr. José Carlos A. Cintra

São Carlos

2005 
"OH! Quão bom e quão suave é que os irmãos vivam em união!

É como o óleo precioso sobre a cabeça, que desce sobre a barba, a barba de Aarão, e que desce à orla dos seus vestidos.

Como o orvalho de Hermom, que desce sobre os montes de Sião: porque ali o Senhor ordena a bênção e a vida para sempre," 
À minha esposa Cilze e aos filhos Leonardo e Maria Eduarda. 


\section{AGRADECIMENTOS}

Ao Grande Arquiteto do Universo pelo amor incondicional.

À minha esposa Cilze pela paciência e aos filhos Leonardo e Maria Eduarda pela compreensão.

Aos meus pais Flávio e Aurora.

Ao Professor Dr. José Carlos A. Cintra pela amizade, orientação e incentivo.

Aos Professores e funcionários do departamento de Geotecnia pela seriedade no trabalho e pela amizade e apoio.

A todos os colegas do curso de pós-graduação pela amizade e apoio, em especial à Angelita Martins da Silva e à Nelci Helena Gutierrez, pela ajuda desinteressada em diversos momentos que tive dificuldades.

Ao colega, Engenheiro Paulo Augustini, da empresa ENGESTRAUSS - Engenharia e fundações, que abriu suas portas para que eu pudesse conhecer um pouco mais sobre os equipamentos de hélice contínua monitorada e de hélice segmentada monitorada.

A todas as empresas construtoras de máquinas e executoras de fundações que me forneceram catálogos, em especial ao amigo, Engenheiro Newton Locali da empresa ESTATEC - Engenharia de fundações, com sede na cidade de Americana-SP que de forma despojada disponibilizou todo o seu material técnico, conseguido em mais de 25 anos de profissão.

A todos os funcionários da empresa E.G.Barreto da qual sou diretor, que de várias formas, colaboraram para que a perfuratriz fosse construída.

Aos amigos que me apoiaram nesta jornada.

A todos, muito obrigado! 


\section{SUMÁRIO}

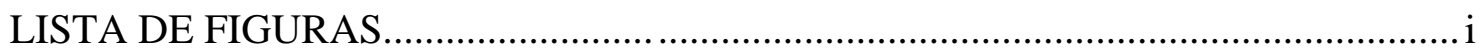

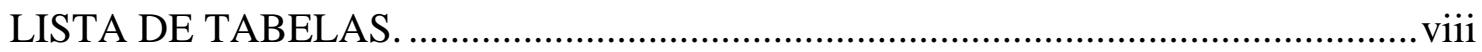

LISTA DE ABREVIATURAS E SIGLAS.............................................................. ix

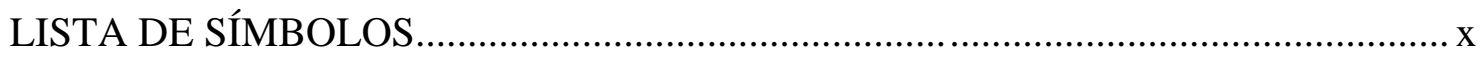

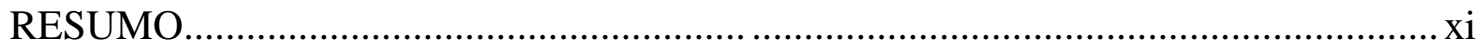

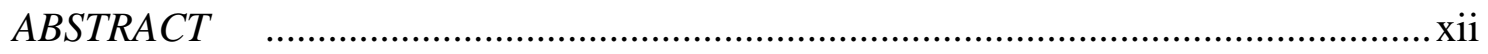

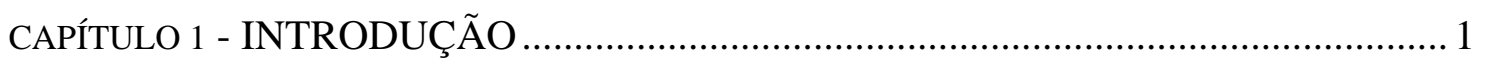

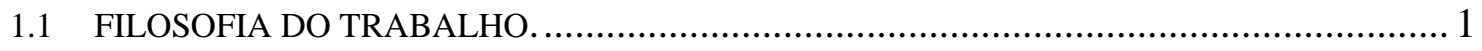

1.2 DESCRIÇÃO RESUMIDA DA ESTACA PRODUZIDA PELO EQUIPAMENTO.................... 1

1.3 PROPOSTA PARA DESENVOLVIMENTO DE PROJETO E CONSTRUÇÃO DO

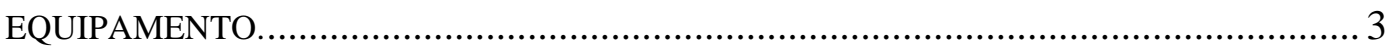

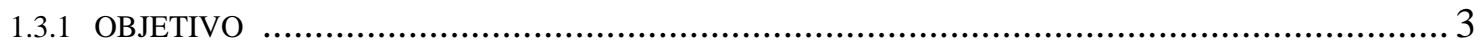

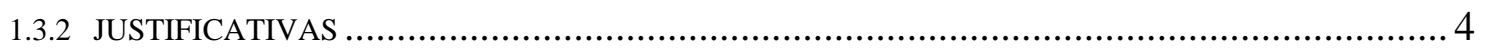

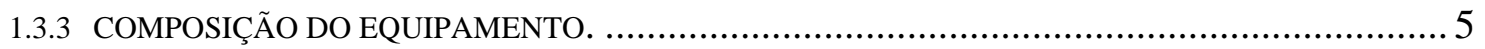

CAPÍTULO 2 - REVISÃO BIBLIOGRÁFICA......................................................... 6

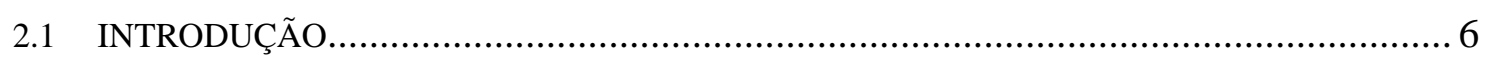

2.2 CONTRIBUIÇÃO BRASILEIRA AO DESENVOLVIMENTO DE PERFURATRIZES ROTATIVAS PARA EXECUÇÃO DE ESTACAS ESCAVADAS EM SOLOS NÃO

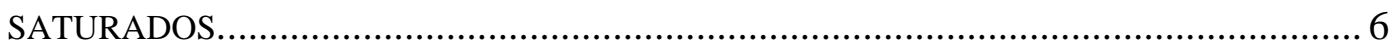

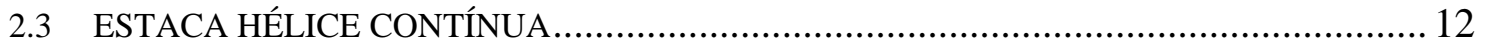

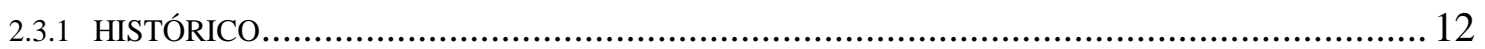

2.3.2 COMPARAÇÃO COM OS TIPOS TRADICIONAIS DE FUNDAÇÕES PROFUNDAS E EVOLUÇÃO

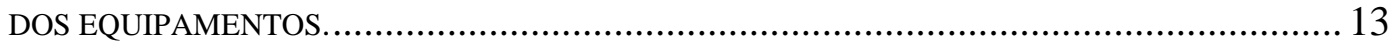

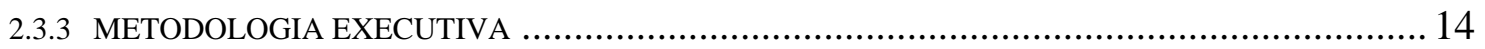

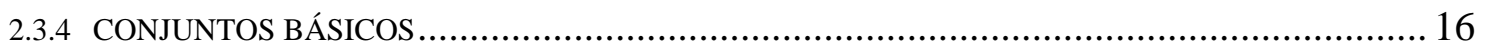

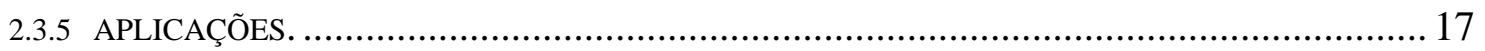

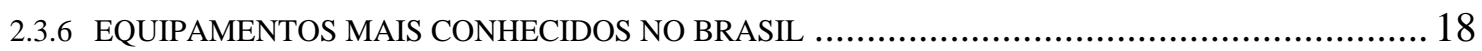

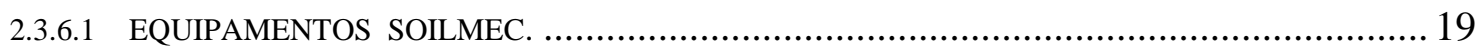


2.3.6.1.1 EQUIPAMENTO R - 208

2.3.6.1.2 EQUIPAMENTO CM - 48

2.3.6.1.3 EQUIPAMENTO R - 622

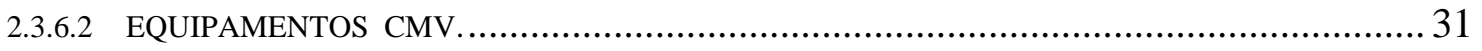

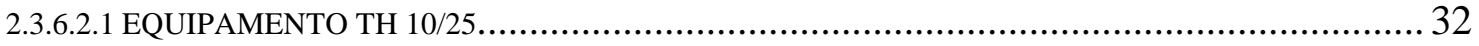

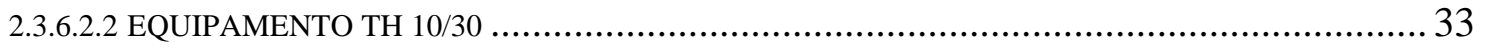

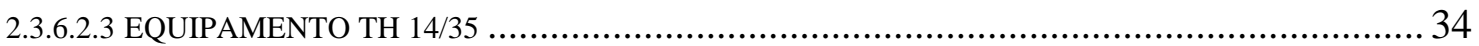

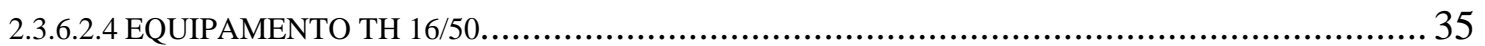

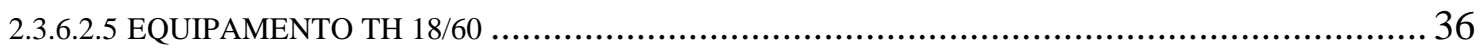

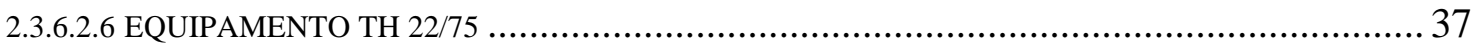

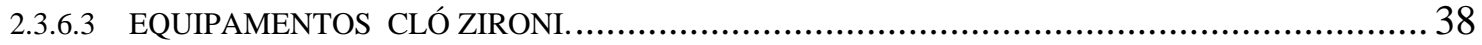

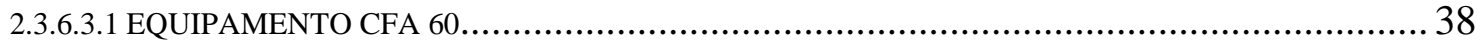

2.3.6.3.2 EQUIPAMENTO CD 30 - CFA................................................................... 40

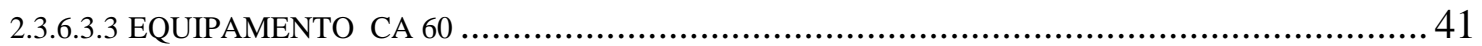

2.3.6.4 EQUIPAMENTOS MAIT. ................................................................... 43

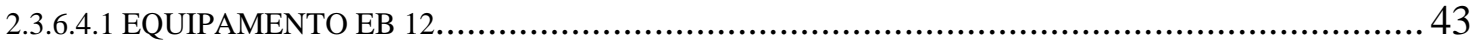

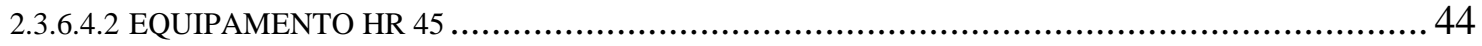

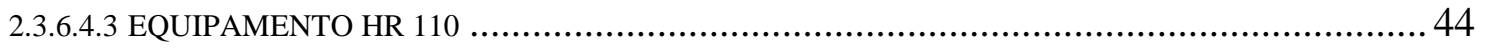

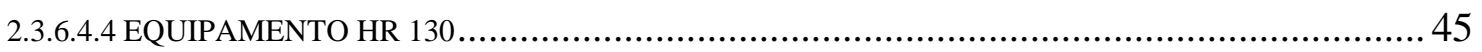

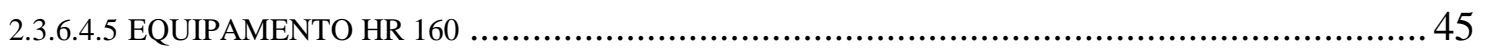

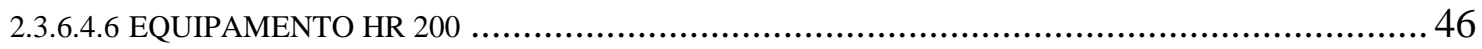

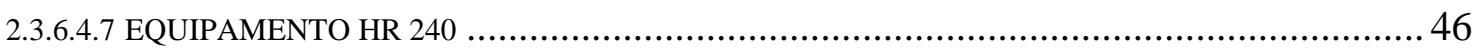

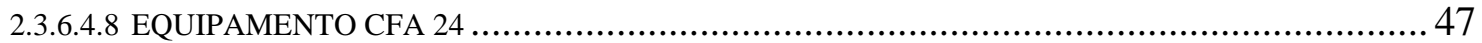

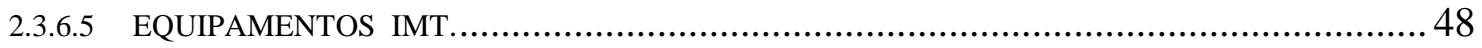

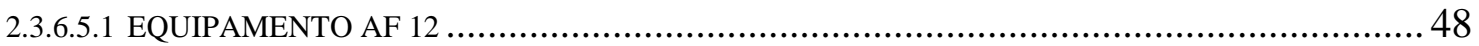

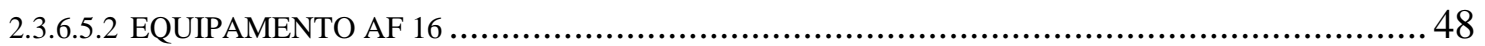

2.4 ESCAVAÇÃO COM TRADOS TUBULARES (HOLLOW-AUGER) ..............................49

2.5 ESTACAS ESCAVADAS DE GRANDE DIÂMETRO ........................................... 51

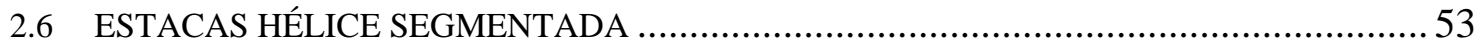

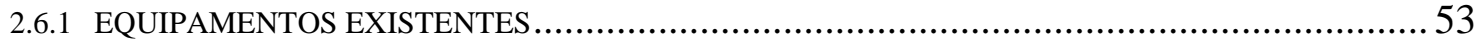

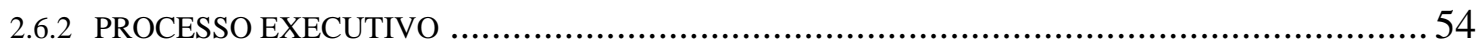




\section{CAPÍTULO 3 - CONSIDERAÇÕES GERAIS SOBRE O EQUIPAMENTO}

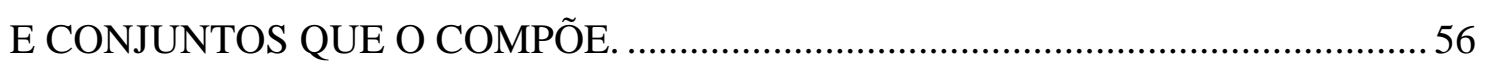

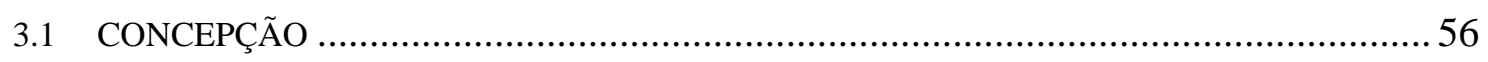

3.2 CONSIDERAÇÕES SOBRE AS CARACTERÍSTICAS TÉCNICAS DO EQUIPAMENTO .... 58

3.3 PRINCIPAIS CONJUNTOS QUE COMPÕE O EQUIPAMENTO ............................................... 59

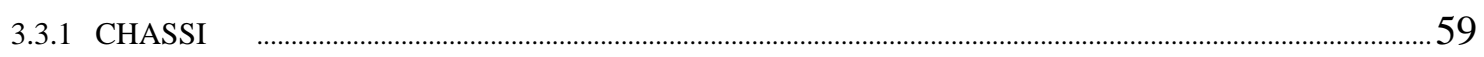

3.3.2 DIREÇÃO E MESA COMPENSADORA ............................................................................................................. 60

3.3.3 SISTEMA DE TRAÇÃO ................................................................................................................................. 62

3.3.4 SISTEMA DE NIVELAMENTO E AUTOCARREGAMENTO ……...........................................................63

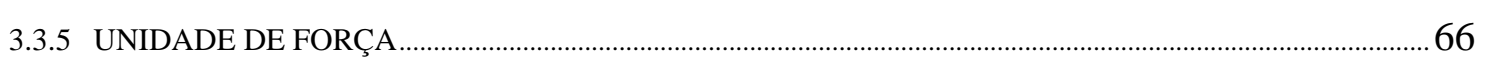

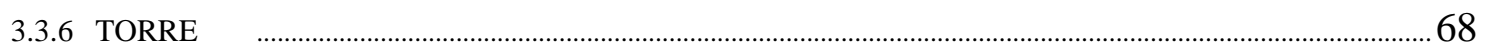

3.3.7 CABEÇOTE ROTATIVO................................................................................................................................. 71

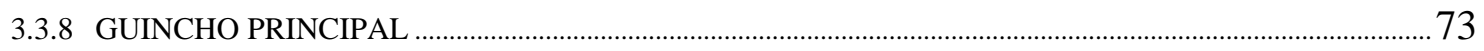

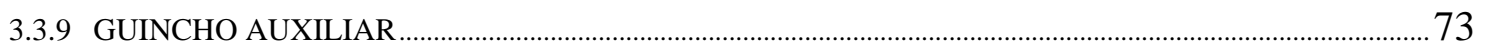

3.3.10 CILINDRO DE EMPUXO AXIAL ……………………………………………………………………………... 74

3.3.11 ALIMENTADOR DE HÉLICES SEGMENTADAS....................................................................................... 77

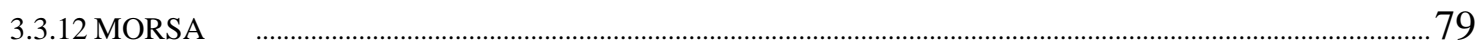

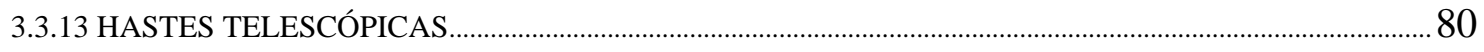

3.3.14 DISPOSITIVO DE INJEÇÃO DE ARGAMASSA.................................................................................................. 82

3.3.15 SISTEMA DE MONITORAMENTO DAS PRESSÕES DE INJEÇÃO................................................................

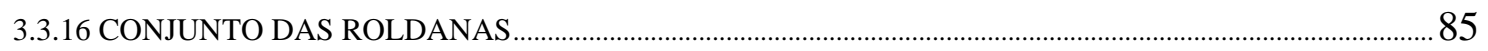

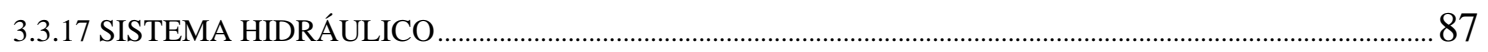

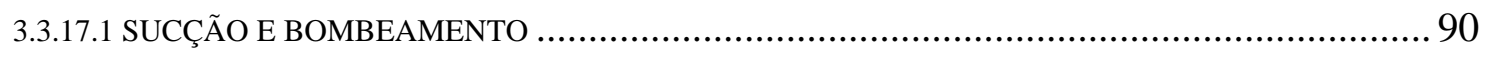

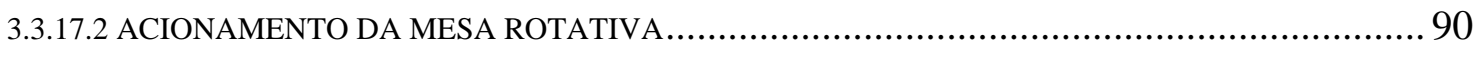

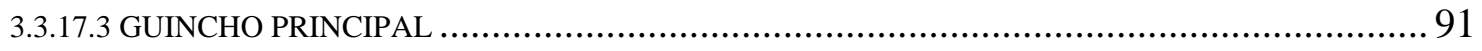

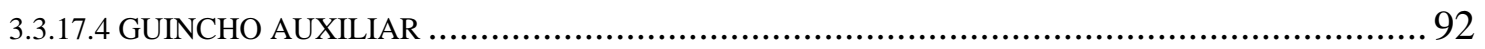

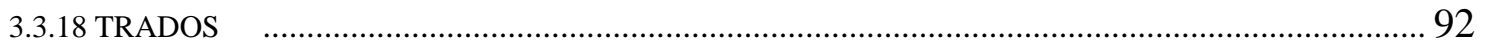

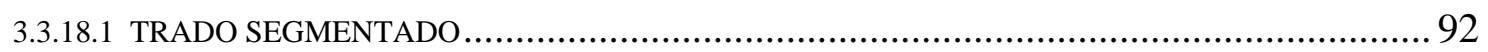

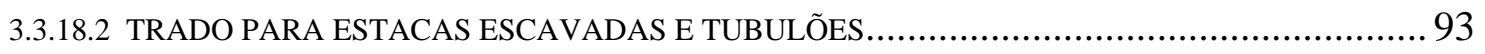

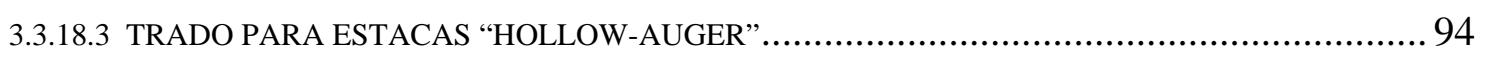

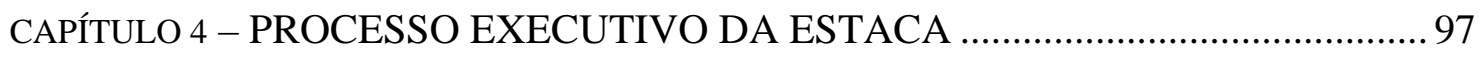

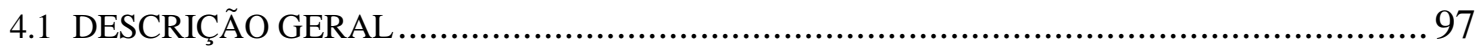




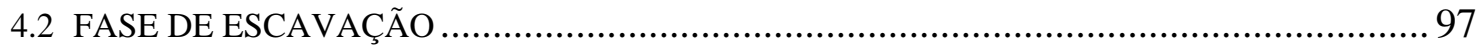

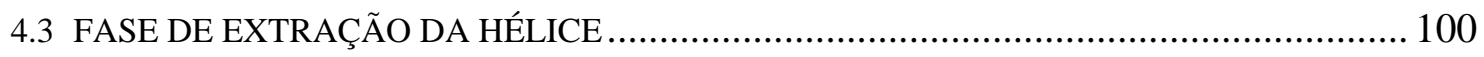

CAPÍTULO 5 - EQUIPE DE COLABORADORES E EQUIPAMENTOS

DE APOIO UTILIZADOS NA EXECUÇÃO DAS ESTACAS ................................... 104

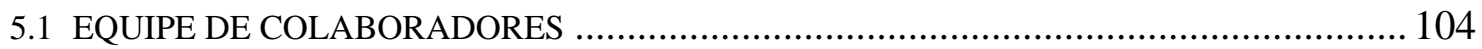

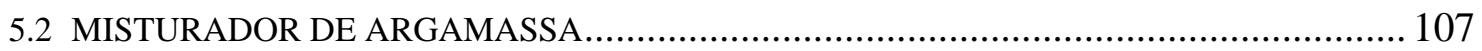

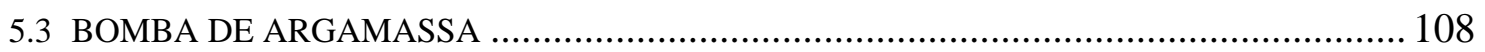

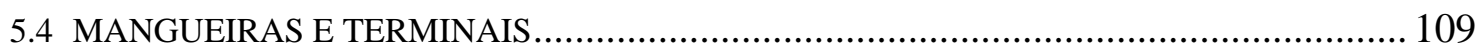

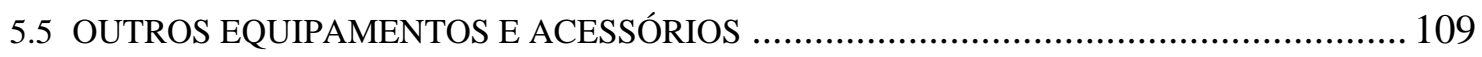

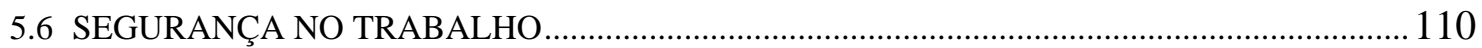

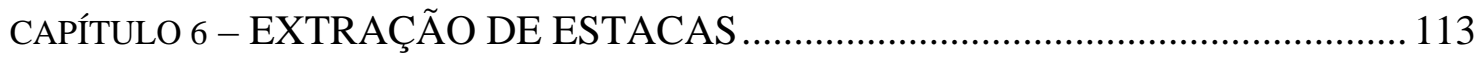

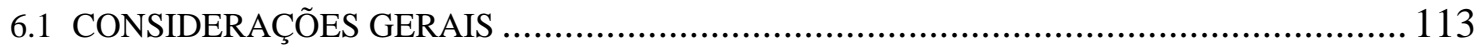

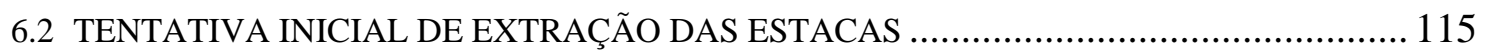

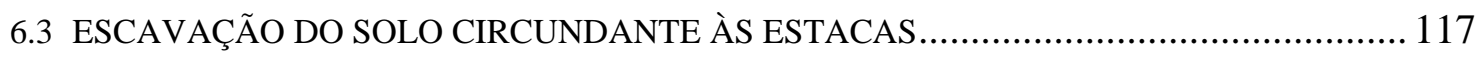

CAPÍTULO 7 - CONCLUSÕES E SUGESTÕES PARA OUTRAS PESQUISAS ....... 123

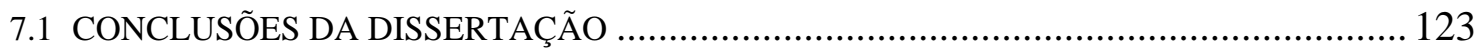

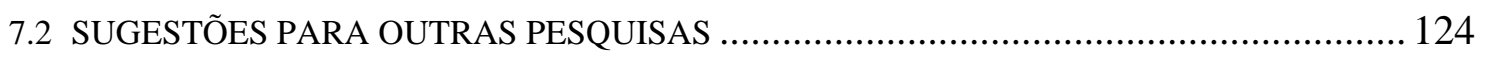

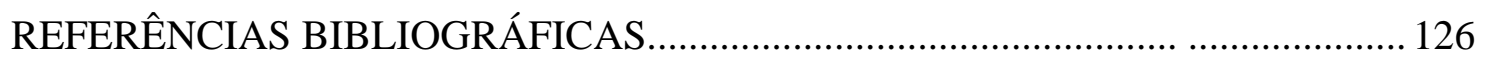




\section{LISTA DE FIGURAS}

Figura 1.1 - Perfuratriz VD 500 CFA - EGTECHNOLOGY (200_?).........................3

Figura 1.2 - Equipamento AF 16 na posição de transporte (IMT, 1995)..................... 4

Figura 2.1 - Perfuratriz M 500 (E.G.Barreto, 1987)................................................. 7

Figura 2.2 - Perfuratriz CD 27 (Cló Zironi, 198-?).................................................... 8

Figura 2.3 - Perfuratriz CD 17 (Cló Zironi, 199-?)..................................................... 8

Figura 2.4 - Equipamento H 800 (E.G.Barreto, 1993) _............................................ 9

Figura 2.5 - Perfuratriz H 800 - Posição de transporte (E.G.Barreto, 1994) ............... 9

Figura 2.6 - H 1000 - Implantação em obra com utilização de guindaste

(E.G.Barreto, 199-?).

Figura 2.7 - Obra “KAISER ARARAQUARA” Utilização de Perfuratrizes

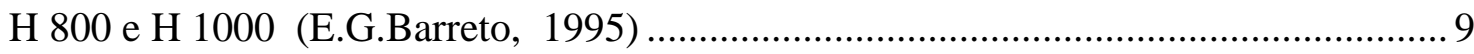

Figura 2.8 - Cervejaria KAISER ARARAQUARA. Obra concluída

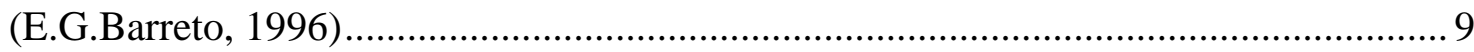

Figura 2.9 - Perfuratriz CL-07 (Cló-Zironi, 199-?).................................................. 9

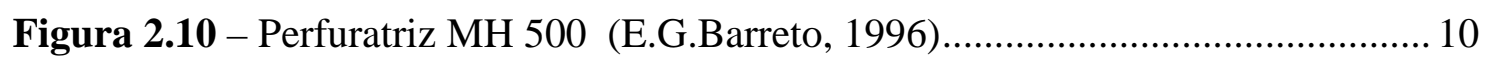

Figura 2.11 - Perfuratriz HT 710 (E.G.Barreto, 1997) .............................................. 10

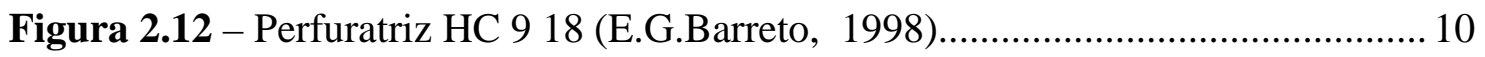

Figura 2.13 - Perfuratriz HC 920 (E.G.Barreto, 1999).............................................. 10

Figura 2.14 - Perfuratriz HT 916 (E.G.Barreto, 1999)............................................... 10

Figura 2.15 - Perfuratriz HC 916 (E.G.Barreto, 2001).............................................. 11

Figura 2.16 - Perfuratriz CD 20 P/PR (Cló Zironi, 2002)........................................... 11

Figura 2.17 - Perfuratriz CD 12 (Cló Zironi, 2002)..................................................... 11

Figura 2.18 - Perfuratriz BS 1000 (BS Tubos \& Bombas, 200-?). ............................... 12

Figura 2.19 - Perfuratriz BS 1200 (BS Tubos, 200-?). ............................................... 12

Figura 2.20 - Hélice montada em guindaste (FUNDESP, 2001). …............................. 14

Figura 2.21 - Equipamento para estacas escavadas de grande diâmetro

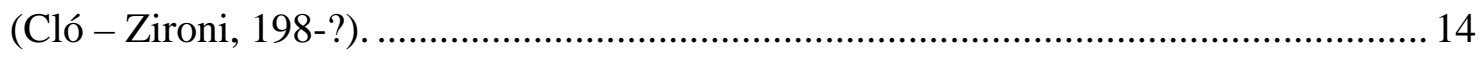

Figura 2.22 - Fases da execução da estaca hélice contínua (Brasfond - 2001). ......... 15

Figura 2.23 - Parte do equipamento eletrônico de monitoramento

(JEAN LUTZ, 199_?).

Figura 2.24 - Relatório final de monitoramento de uma estaca.

(FUNDESP, 2001) 
Figura 2.25 - Detalhe da tampa de proteção da ponta da hélice (ENGESTRAUSS, 200-?).

Figura 2.26 - Perfuratriz R -622 (SOILMEC, 199-?) .............................................. 17

Figura 2.27 - Perfuratriz CFA-24 (MAIT, 199-?)........................................................ 17

Figura 2.28 - Perfuratriz R-208 (SOILMEC, 1995). ................................................. 19

Figura 2.29 - Vista lateral da perfuratriz R 208 (SOILMEC, 1995)............................. 20

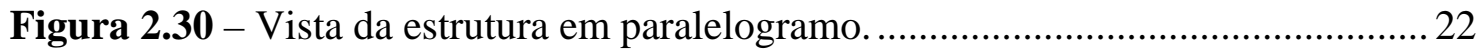

Figura 2.31 - Vista dos cilindros superiores da torre. ............................................. 22

Figura 2.32 - Perfuratriz R 208 - Vista da mesa rotativa. ........................................... 22

Figura 2.33 - Vista das condições do terreno e concreto envolvendo

a hélice, após a concretagem

Figura 2.34 - Perfuratriz CM-48 - vista da mesa rotativa

(SOILMEC, 199-?) 25

Figura 2.35 - CM-48 - Vista da cabine de operação - (SOILMEC, 199-?) .................. 25

Figura 2.36 - CM-48 Vista geral do equipamento (SOILMEC, 199-?) ....................... 25

Figura 2.37 - CM-48 - Dimensões principais (SOILMEC, 199-?)............................... 25

Figura 2.38 - CM-48 - Execução de estaca tubada......................................................26

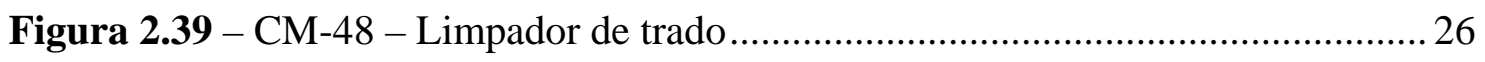

Figura 2.40 - R-622 - Execução de estacas hélice contínua .......................................... 27

Figura 2.41 - R 622 - Dimensões principais. Montagem para estacas hélice contínua. SOILMEC (199-?). 28

Figura 2.42 - R 622 - Dimensões principais. Montagem para estacas escavadas de grande diâmetro. SOILMEC (199-?) 29

Figura 2.43 - R 622 - Montagem para execução de paredes diafragma ....................... 30

Figura 2.44 - R 622 - Montagem para estacas tubadas e concretadas in loco.............. 30

Figura 2.45 - TH 10/25 - Dimensões principais (CMV, 2000).................................... 32

Figura 2.46 - TH 10/25 - Vista de escavação com utilização de balde

(CMV, 2000) 32

Figura 2.47 - TH 10/30 - Vista executando estaca hélice (CMV, 2000) ..................... 33

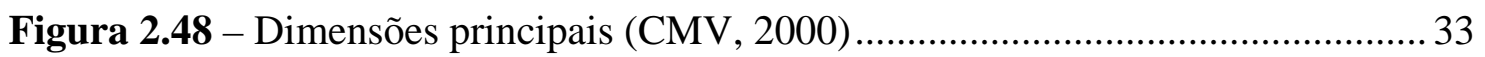

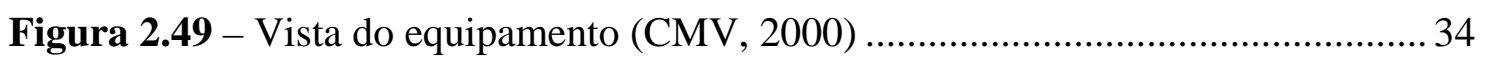

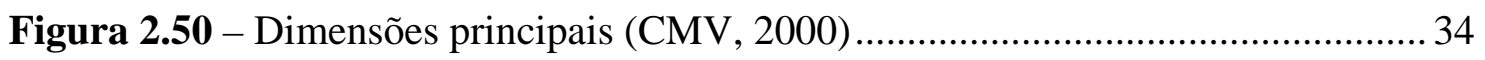

Figura 2.51 - TH 16/50 - Vista do equipamento (CMV, 2000) .................................... 35

Figura 2.52 - TH 16/50-Dimensões principais (CMV, 2000) …................................... 35 
Figura 2.53 - TH 18/60 - Vista do equipamento (CMV, 2000)...................................36

Figura 2.54 - TH 1860 - Dimensões principais (CMV, 2000) ................................... 36

Figura 2.55 - TH 22/75 - Vista do equipamento (CMV, 2000)................................. 37

Figura 2.56 - TH 22/75 - Dimensões principais (CMV, 2000) …............................... 37

Figura 2.57 - Equipamento CFA 60 (Cló Zironi, 200-?) ............................................. 39

Figura 2.58 - CFA 60 - Dimensões principais (Cló Zironi, 200-?) ............................. 39

Figura 2.59 - CFA 60 - Posição de transporte (Cló Zironi, 200-?).............................. 39

Figura 2.60 - Articulação da torre (Cló Zironi, 2001).................................................. 40

Figura 2.61 - Vista geral - CD 30 - CFA (Cló Zironi, 2001) .................................... 40

Figura 2.62 - Vista do mecanismo transmissor de torque no sistema "bottom drive”. 41

Figura 2.63 - Vista do equipamento CA 60, caminhão betoneira e bomba de concreto (Cló Zironi, 2001)

Figura 2.64 - Equipamento CA 60 - Vista mesa rotativa e esteira (Cló Zironi, 2001) 42

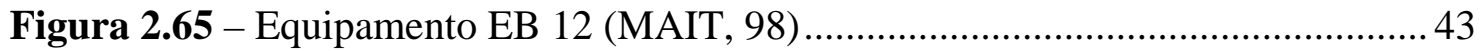

Figura 2.66 - EB 12 - Dimensões principais (MAIT, 98).........................................43

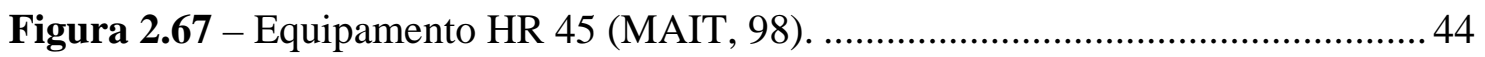

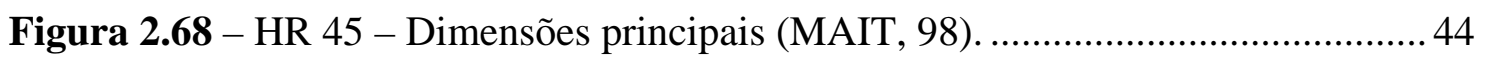

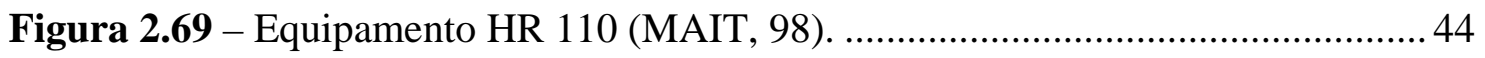

Figura 2.70 - HR 110 - Dimensões principais (MAIT, 98)......................................... 44

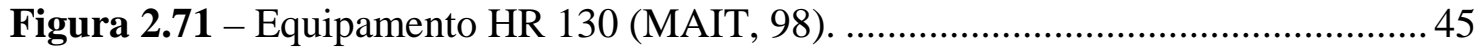

Figura 2.72 - HR 130 - Dimensões principais (MAIT, 98) ….................................... 45

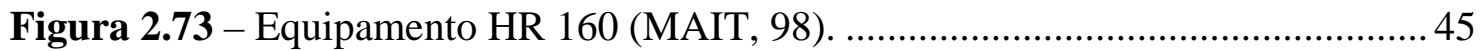

Figura 2.74 - HR 160 Dimensões principais (MAIT, 98).......................................... 45

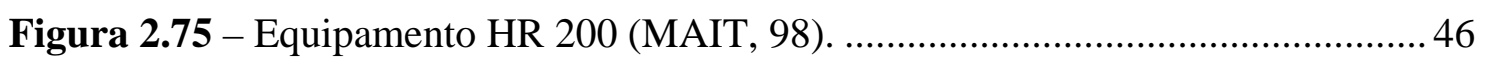

Figura 2.76 - HR 200 - Dimensões principais (MAIT, 98) ....................................... 46

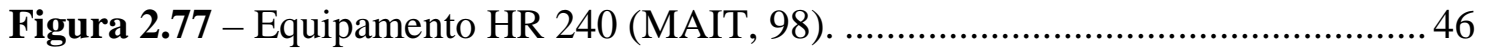

Figura 2.78 - HR 240 - Dimensões principais (MAIT, 98) ........................................ 46

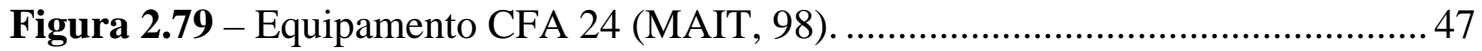

Figura 2.80 - CFA 24 - Dimensões principais (MAIT, 98)....................................... 47

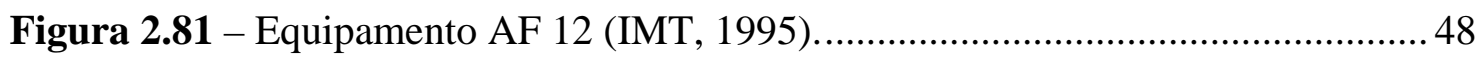

Figura 2.82 - AF 12 - Dimensões principais (IMT, 1995). .......................................... 48

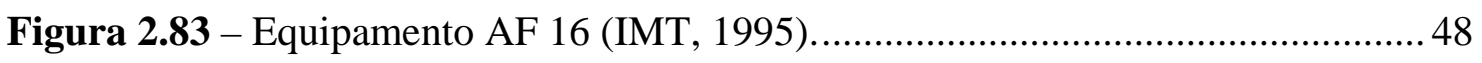

Figura 2.84 - AF 16 - Dimensões principais (IMT, 1995). ........................................ 48

Figura 2.85 - Estaca com Trado Oco (Wirth, 19--?), ....................................................50 
Figura 2.86 -Equipamento com trado "hollow-auger” (Cló Zironi,199-?) ...................50

Figura 2.87 - Perfuratriz HT 710 -Execução de sondagens em aterro sanitário, na cidade de Leme - SP (E.G.Barreto, 2004). 50

Figura 2.88 - Sonda CME 55 - Utiliza trados ocos Cortesia Alphageos (2000).......... 51

Figura 2.89 - Trado do tipo “Hollow Auger”. Detalhe da tampa de proteção da ponta (E.G.Barreto, 2003). 51

Figura 2.90 - Esquema de execução de estacas de Grande diâmetro com utilização de lama bentonítica (FUNDESP, 2001). 52

Figura 2.91 - Esquema de execução de estacas de grande diâmetro com utilização de camisa metálica (FUNDESP, 2001). 52

Figura 2.92 - Perfuratriz MD-3000 (EGTECHNOLOGY, 2002)............................... 53

Figura 2.93 - MD 3000 - Mecanismo alimentador (EGTECHNOLOGY, 2002)........ 54

Figura 3.1 - Esquema da perfuratriz com torre na posição de manobra.....................59

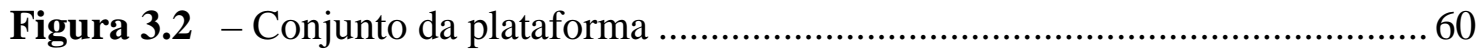

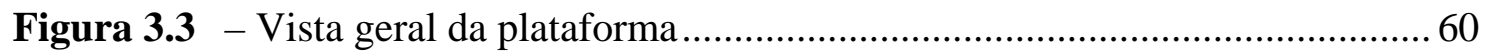

Figura 3.4 - Conjunto da mesa compensadora (balança)............................................ 62

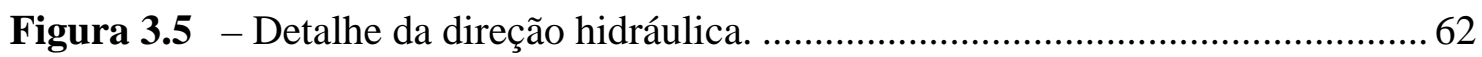

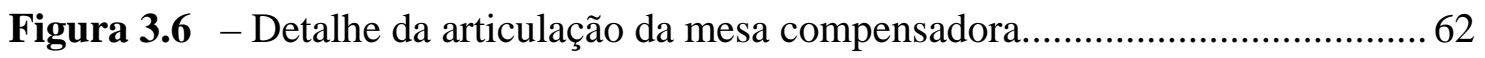

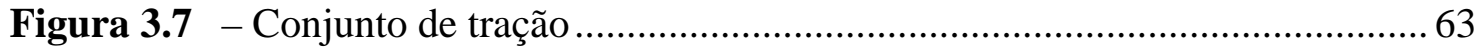

Figura 3.8 - Sistema de nivelamento e autocarregamento......................................... 64

Figura 3.9 - Equipamento com os quatro apoiados cilindros apoiados no solo. .........64

Figura 3.10 - Detalhe de um cilindro de nivelamento e autocarregamento. ................. 64

Figura 3.11 - Vista da perfuratriz durante a operação de autocarregamento. ...............65

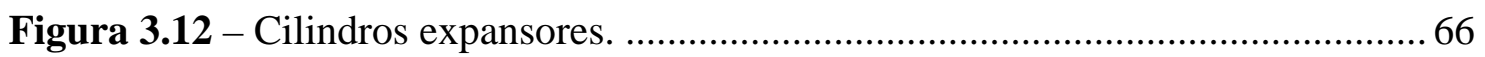

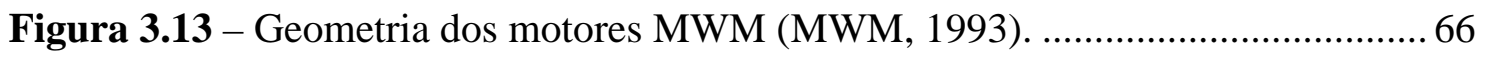

Figura 3.14 - Curva de desempenho do motor MWM modelo

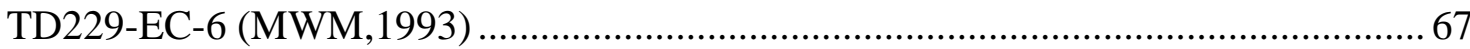

Figura 3.15 - Unidade de força instalada na plataforma. ............................................. 68

Figura 3.16 - Montagem dos conjuntos sobre a torre.................................................69

Figura 3.17 - Vista da torre com haste para estacas escavadas e tubulões.................... 70

Figura 3.18 - Torre na posição de trabalho com montagem para estaca hélice

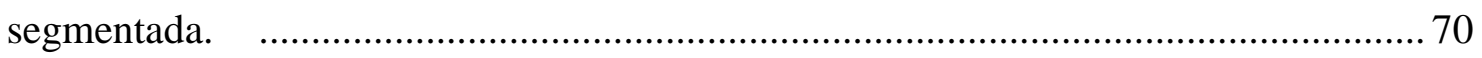

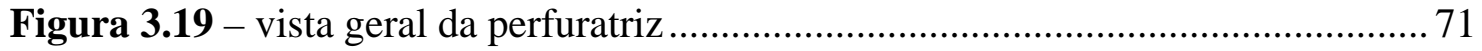

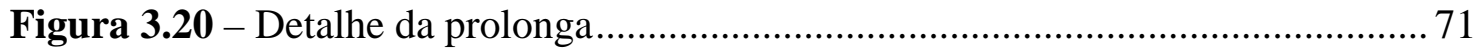




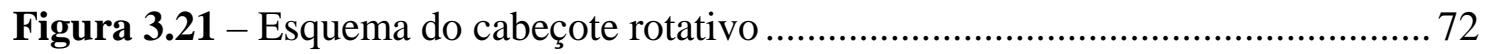

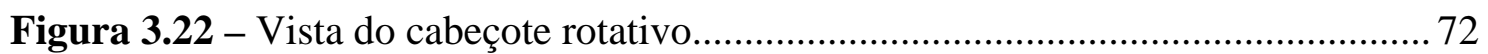

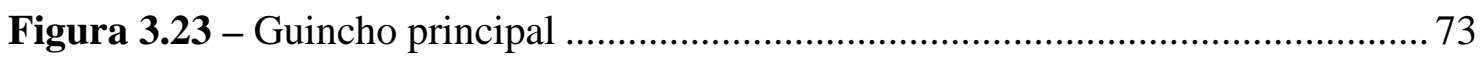

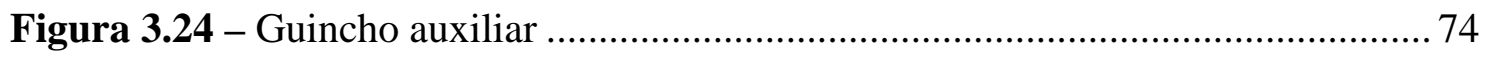

Figura 3.25 - Cilindro de simples efeito com retorno por mola (Palmieri, 1985)....... 74

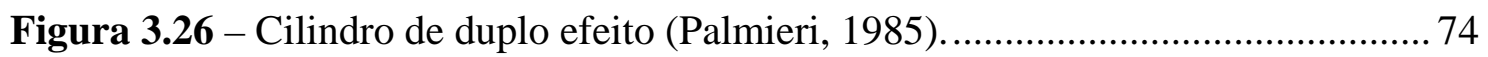

Figura 3.27 - Aplicações para cilindros (Palmieri, 1985)........................................... 75

Figura 3.28 - Cilindro de haste simples e dupla ação (REXROTH, 1988). .................. 76

Figura 3.29 - Cilindro de haste dupla (REXROTH, 1985)........................................ 76

Figura 3.30 - Cilindro com hastes telescópicas (Palmieri, 1985)............................... 76

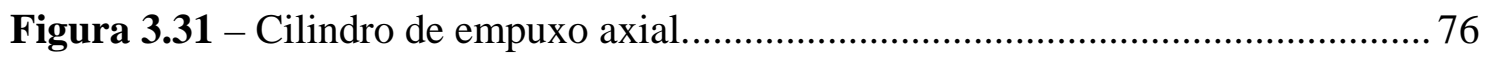

Figura 3.32 - Esquema de montagem do cilindro de empuxo axial. .......................... 77

Figura 3.33 - Vista do cilindro de empuxo axial montado na torre............................. 77

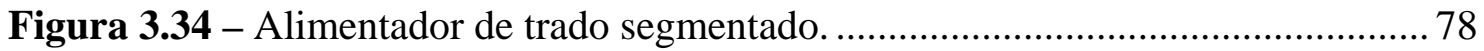

Figura 3.35- Vista do alimentador de segmentos de hélice........................................ 78

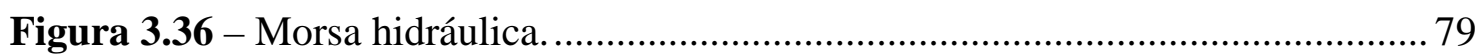

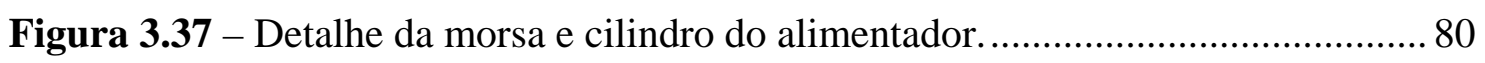

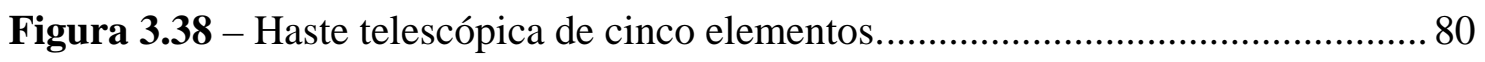

Figura 3.39 - Haste telescópica de dois elementos...................................................... 81

Figura 3.40 - Vista do equipamento com conjunto telescópico de cinco elementos.... 82

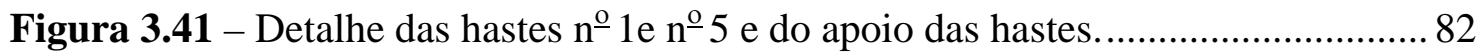

Figura 3.42 - Vista da haste $\mathrm{n}^{\mathrm{o}} 5$ (circular), $\mathrm{n}^{\mathrm{o}} 4$ (tubo quadrado), $\mathrm{n}^{\mathrm{o}} 1$

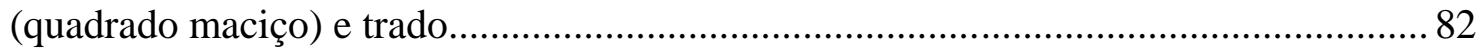

Figura 3.43 - Vista da parte superior do conjunto de hastes telescópicas. .................... 82

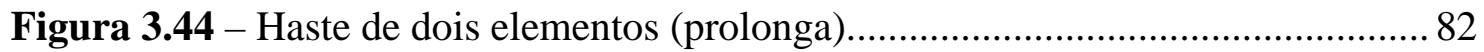

Figura 3.45 - Haste de dois elementos (detalhe das ranhuras na haste interna)........... 82

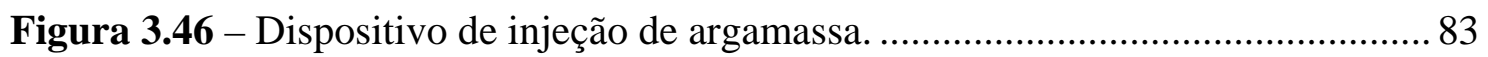

Figura 3.47 - Vista do swivel com manômetro analógico instalado

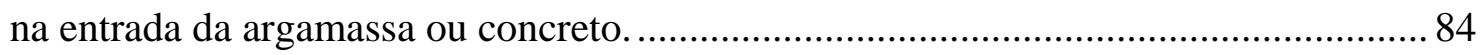

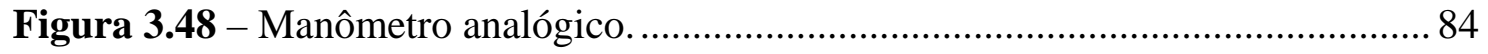

Figura 3.49 - Manômetro digital composto e um transmissor e um receptor. ............. 85

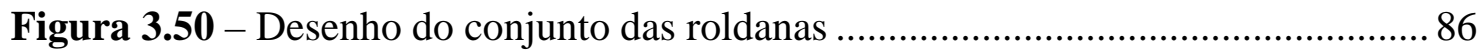

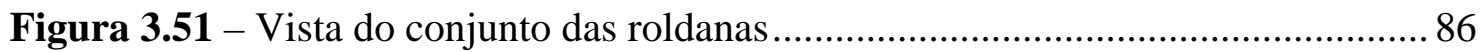


Figura 3.52 - Circuito hidráulico do sistema de sucção e recalque ..............................90

Figura 3.53 - Circuito hidráulico da mesa rotativa....................................................90

Figura 3.54 - Circuito hidráulico do guincho principal .......................................... 91

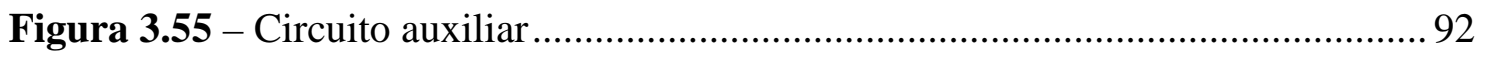

Figura 3.56 - Trados para a execução de estaca hélice segmentada.............................. 92

Figura 3.57 - Fase de início da emenda de um segmento de hélice.............................93

Figura 3.58 - Fase final da emenda de um segmento de hélice.................................. 93

Figura 3.59 - Vista das ferramentas de corte e da hélice de um trado curto. ................93

Figura 3.60 - Parte superior de um trado curto. ......................................................... 93

Figura 3.61 - Vista do equipamento escavando um tubulão. .....................................94

Figura 3.62 - Segmento de trado tipo “Hollow-Auger”. ............................................. 95

Figura 3.63 - Detalhe do acoplamento do Trado "Hallow-Auger". ............................ 95

Figura 3.64 - Vista do lançamento de concreto em uma estaca do tipo

"Hollow - Auger". 95

Figura 3.65 - Execução de estaca “hollow-auger” com o equipamento na posição de trabalho.

Figura 3.66 - Execução de estacas "hollow-auger” com abaixamento

da torre para a posição horizontal (posição de manobra).............................................96

Figura 4.1 - Posição de início da escavação da estaca. ...............................................98

Figura 4.2 - Fase de escavação com instalação da ponteira e

parte do trado segmentado.

Figura 4.3 - Fase de instalação da hélice com a colocação de um segmento de trado do alimentador para a posição de trabalho.

Figura 4.4 - Fase de extração do primeiro segmento de hélice. ............................... 100

Figura 4.5 - Fase de extração com término da estaca.............................................. 101

Figura 4.6 - Fase de escavação de uma estaca............................................................ 101

Figura 4.7 - Fase de extração da hélice com vista do confinamento do solo. ........... 102

Figura 4.8 - Vista da expulsão de argamassa no final da extração da hélice............. 102

Figura 4.9 - Torre sendo posicionada na horizontal para a manobra do equipamento para outra estaca.

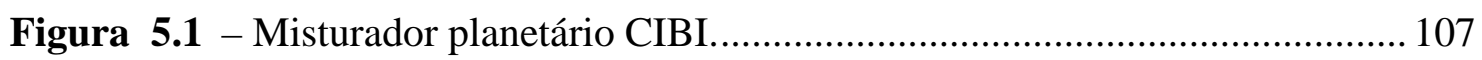

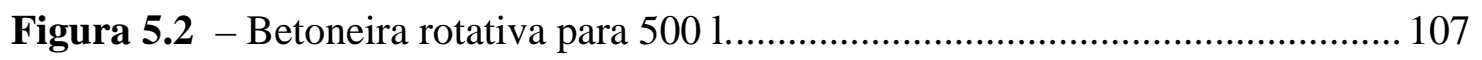

Figura 5.3 - Vista do sistema planetário no interior da caçamba do misturador marca CIBI 
Figura 5.4 - Vista de uma pá do misturador planetário CIBI. 107

Figura 5.5 - Misturador com eixo de giro das pás concêntrico em relação à caçamba do misturador...

Figura 5.6 - Vista da bomba de argamassa e betoneira

utilizadas nas estacas executadas, para posterior extração 108

Figura 6.1 - Relatório de um furo de sondagem (SPT). 114

Figura 6.2 - Locação do furo de sondagem e das estacas $E_{1}$ e $E_{2}$. 115

Figura 6.3 - Tentativa de extração de uma estaca com utilização de um cilindro hidráulico.

Figura 6.4 - Unidade hidráulica utilizada para acionamento do cilindro. 116

Figura 6.5 - Fase inicial da escavação mecanizada do solo circundante à estaca. ... 117

Figura 6.6 - Fase intermediária da escavação mecanizada do solo circundante à estaca.

Figura 6.7 - Fase final da escavação mecanizada do solo circundante à estaca.

Figura 6.8 - Seqüência da extração da estaca $E_{1}$ com utilização de um guincho, após a escavação do solo circundante. 119

Figura 6.9 - Seqüência da extração da estaca $E_{2}$. 120

Figura 6.10 - Estaca $E_{2}$ extraída e sendo colocada na carroceria do caminhão. 121

Figura 6.11 - Detalhe da ruptura ocorrida na ponta da estaca $E_{1}$

Figura 6.12 - Detalhe da ruptura ocorrida na ponta da estaca $E_{2}$ 121 


\section{LISTA DE TABELAS}

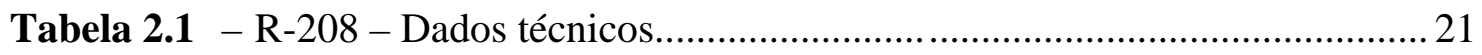

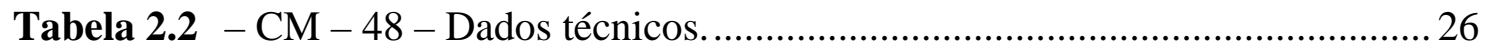

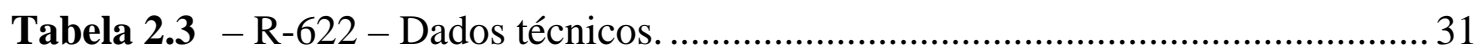

Tabela 2.4 - Dados técnicos dos equipamentos CMV - Série TH.............................38

Tabela 2.5 - Dados técnicos dos equipamentos CLÓZIRONI.................................... 43

Tabela 2.6 - Dados técnicos dos equipamentos MAIT ........................................... 47

Tabela 3.1 - Dimensões principais dos motores MWM (MWM, 1993) ...................... 66 


\section{LISTA DE ABREVIATURAS E SIGLAS}

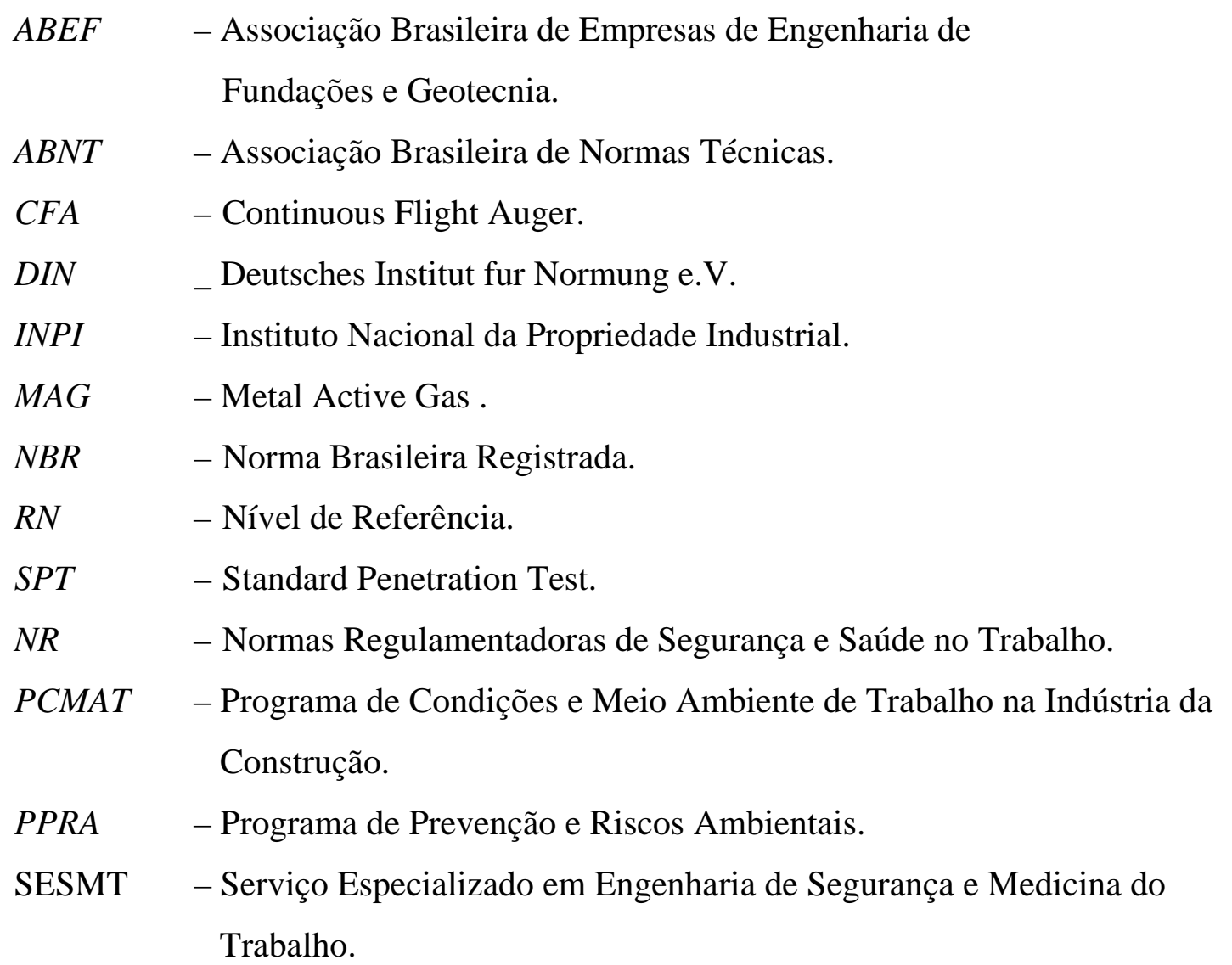




\section{LISTA DE SÍMBOLOS}

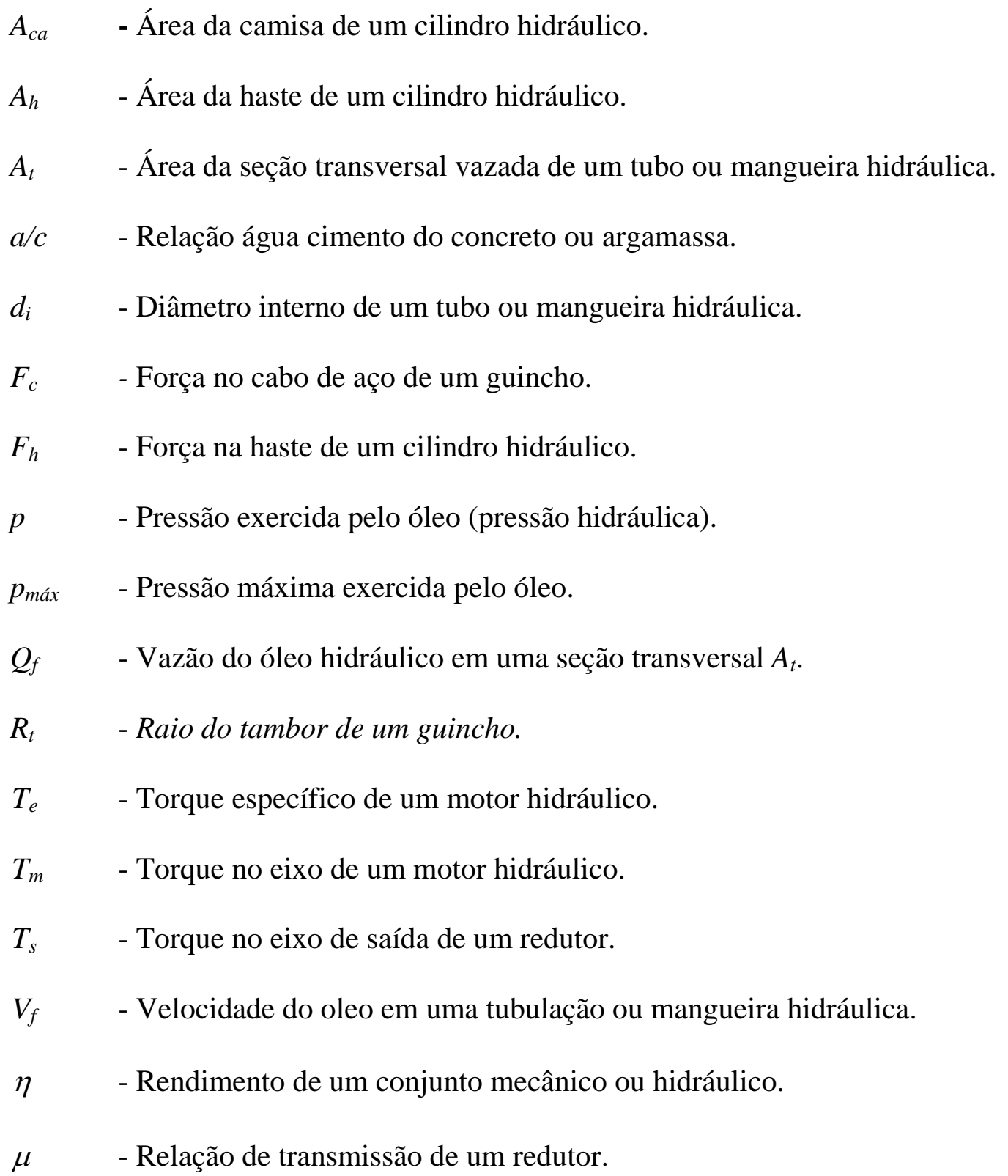




\section{RESUMO}

BARRETO, G.W. Desenvolvimento de um equipamento para a execução de estacas hélice segmentada. São Carlos, 2004. 131 p. Dissertação (Mestrado)- Escola de Engenharia de São Carlos, Universidade de São Paulo.

Esta dissertação apresenta o desenvolvimento de um equipamento para a execução de estacas escavadas com injeção sob pressão, logo após a fase de escavação, de argamassa de cimento e areia. O processo utiliza segmentos de trados que são introduzidos no solo através da combinação de rotação e empuxo axial de compressão. A extração dá-se simultaneamente à injeção de argamassa, e o monitoramento das pressões de injeção é feito através de um manômetro, com o objetivo de garantir a integridade do fuste. Um motor a diesel fornece até $92 \mathrm{~kW}$ a $1800 \mathrm{rpm}$ e é responsável pelo acionamento dos diversos conjuntos hidráulicos. O equipamento, montado numa plataforma sobre pneus, é autopropelido e autocarregável podendo ser transportado em caminhões comuns com dois eixos traseiros. Esse tipo de estaca, denominado estaca hélice segmentada, poderá representar uma alternativa interessante às estacas tradicionais, principalmente em locais onde as construções vizinhas possam sofrer danos devido à utilização de estacas de deslocamento ou onde os custos envolvidos na utilização de equipamento mais pesado e sofisticado possam inviabilizar a sua aplicação.

Palavras-chave: Estaca; hélice segmentada; estaca injetada. 


\begin{abstract}
BARRETO, G.W. Development of equipment for execution of segmented auger piles. São Carlos, 2004. 131 p. Dissertação (Mestrado) - Escola de Engenharia de São Carlos, Universidade de São Paulo.

This work presents the development of equipment for execution of segmented auger piles with injection of cement mortar under pressure, soon after the excavation phase. The process uses segmented augers that are installed in the ground through the rotation and pull-down combination. The extraction is made at the same time as the cement mortar injection and the injection pressures are monitored by a manometer, to assure the shaft integrity. A diesel motor offers up $92 \mathrm{~kW}$ at $1800 \mathrm{rpm}$ and is responsible for the movement of several hydraulic units. The equipment mounted on a tire platform, is selfpropelling and can raise itself to be loaded onto common trucks. This kind of pile, called segmented pile, will be an interesting alternative for the traditional piles, mainly at sites where the neighboring constructions will be damage by the utilization of the displacement pile, or where the costs involved in the utilization of heavier and sophisticated equipment can make its application unfeasible.
\end{abstract}

Keywords: Pile; segmented pile; inject pile. 


\section{CAPÍTULO 1}

\section{INTRODUÇÃO}

\subsection{FILOSOFIA DO TRABALHO}

As estacas Franki, as escavadas com ou sem fluido de contenção do fuste, as prémoldadas de concreto, as estacas metálicas, as do tipo raiz, e mais recentemente as estacas denominadas “Omega”, após instaladas no maciço de solo ou rocha, constituemse em elementos de fundações profundas conhecidos e utilizados no Brasil.

Os processos executivos dos diversos tipos de estacas não aparentam ser complicados, no entanto, os equipamentos utilizados nesses processos estão se tornando cada vez mais potentes, pesados, complexos e caros. Quando se trata de grandes obras, a utilização desses equipamentos se justifica tanto do ponto de vista técnico quanto econômico. No entanto, nas pequenas obras de fundações, as quais representam uma parcela significativa em relação ao total das obras executadas em nosso país, são nítidas as dificuldades que se tem em acompanhar a evolução tecnológica, que sem dúvida muito contribui para a aplicação da boa técnica da engenharia.

A evolução da engenharia geotécnica é dependente dos avanços nas tecnologias dos equipamentos envolvidos nas soluções dos problemas de solos e rochas. O presente trabalho de desenvolvimento e construção de um equipamento para a execução de estacas aqui denominadas "Hélice segmentada”, trará uma importante contribuição à engenharia de fundações, pelo menos no que diz respeito às pequenas obras.

\subsection{DESCRIÇÃO RESUMIDA DA ESTACA PRODUZIDA PELO EQUIPAMENTO}

O equipamento objeto da presente dissertação produz estacas moldadas in loco, utilizando um conjunto de trados segmentados que penetram no solo através de rotação combinada com um empuxo axial de compressão nas hélices segmentadas. A extração 
dos segmentos de hélice é feita simultaneamente à injeção de argamassa de cimento e areia, sob pressões que são monitoradas por um manômetro analógico ou digital. $\mathrm{O}$ equipamento permite executar estacas com diâmetros de $0,20 \mathrm{~m} \mathrm{0,25} \mathrm{m}$ e 0,30 m com comprimento máximo de $14 \mathrm{~m}$. Para diâmetros maiores como por exemplo $40 \mathrm{~cm}$, o equipamento não foi testado mas serão possíveis de ser executadas estacas com menores comprimentos ou com o mesmo comprimento, porém em terrenos menos resistentes. Com relação à resistência estrutural da estaca, para que numa eventual prova de carga possa ser aplicada o dobro da carga de trabalho da estaca e admitindo-se que durante o ensaio seja esgotada 90\% da resistência da argamassa (Alonso, 1993), para uma estaca injetada, comprimida, pode-se escrever:

$$
2 N=0,9\left(0,85 A_{c} f_{c k}+A_{s}^{\prime} f_{y k}\right)
$$

Para $\mathrm{A}_{\mathrm{s}}^{\prime}=0$ (estaca considerada sem armadura), tem-se:

$$
2 N=0,9.0,85 A_{c} f_{c k}
$$

logo, tem-se:

$$
\sigma_{c}=\frac{N}{A}=0,383 f_{c k}
$$

onde: $f_{c k} \leq 20 M P a$

Adotando-se $f c k=20 \mathrm{MPa}$ tem-se:

$$
\sigma_{c} \cong 7,6 \mathrm{MPa}
$$

Há poucos anos, na Itália, a empresa EGTECHNOLOGY iniciou o desenvolvimento de equipamentos leves e dotados de torres com alturas reduzidas, quando comparados com os equipamentos convencionais de hélice contínua (Figura 1.1). O objetivo inicial do projeto foi viabilizar a aplicação do equipamento em áreas confinadas onde as máquinas convencionais de estacas hélice contínua não tinham acesso. Os construtores desses equipamentos continuaram com a sigla CFA (Continuous Flight Auger). No 
Brasil, existem poucas máquinas desse tipo em operação e muitos engenheiros ainda não as conhece, sendo que entre os profissionais que já tiveram a oportunidade de utilizá-las, parece que o nome "Estaca hélice segmentada” está se tornando comum.
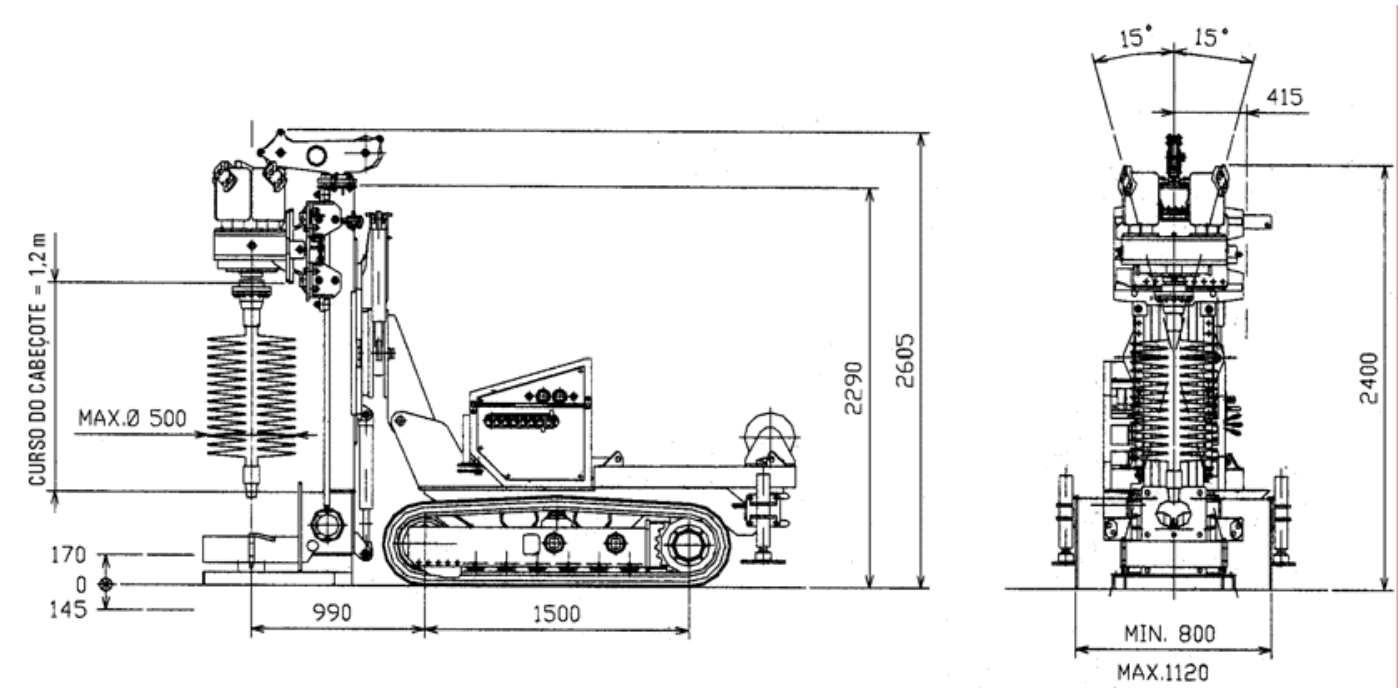

Figura 1.1 - Perfuratriz VD 500 CFA - EGTECHNOLOGY (200_?).

\subsection{PROPOSTA PARA DESENVOLVIMENTO DE PROJETO \\ E CONSTRUÇÃO DO EQUIPAMENTO}

\subsubsection{OBJETIVO}

O objetivo da dissertação de mestrado é o desenvolvimento do projeto e construção de um equipamento para a execução de estacas hélice segmentada que possa satisfazer os seguintes requisitos:

- Ser um equipamento multifunção, para executar estacas escavadas, tubulões, estacas com trado oco (hollow-auger) e estacas hélice com trado segmentado.

- Ser mais leve e dotado de torre mais curta que aquelas normalmente utilizadas nos equipamentos existentes de hélice contínua convencional.

- Utilizar chassi sobre rodas de pneus com sistema autopropelido que resulte em custo menor que o mecanismo sobre esteiras.

- Viabilizar a utilização do equipamento em obras menores que aquelas que atualmente estão sendo implantados os equipamentos de hélice contínua.

- Viabilizar a utilização das estacas hélice segmentada em obras onde são comuns a utilização de outros tipos de fundações profundas.

- Dotar o equipamento de sistema autocarregável, para viabilizar o transporte do mesmo em caminhões comuns, evitando a utilização de carretas. 
- Utilizar sistema de monitoramento das pressões de injeção, mais simples que os utilizados atualmente no processo da hélice contínua, de custo mais baixo, mas que garanta a integridade do fuste da estaca.

- Utilizar argamassa injetada através de bomba apropriada ao invés de concreto.

\subsubsection{JUSTIFICATIVAS}

Entende-se que as vantagens na utilização do sistema proposto em relação às hélices contínuas convencionais serão as seguintes:

- Dimensões reduzidas do equipamento tanto em projeção horizontal quanto com relação à altura da torre, permitindo o trabalho em terrenos pequenos e até no interior de galpões.

- Menor peso do equipamento e sistema autocarregável, possibilitando o transporte em caminhões comuns.

- Valores menores das taxas de mobilização de equipamento e pessoal mesmo em obras pequenas. No sistema convencional os equipamentos normalmente pesam entre 300 e 750 kN, o que exige a utilização de veículos especiais para transporte (Figura 1.2). Esse fato faz com que os custos para instalação do equipamento sejam elevados e na maioria das vezes, inviabiliza esse tipo de solução. Pretende-se reduzir os custos com mobilizações em até cinco vezes em relação aos apropriados para as hélices contínuas.

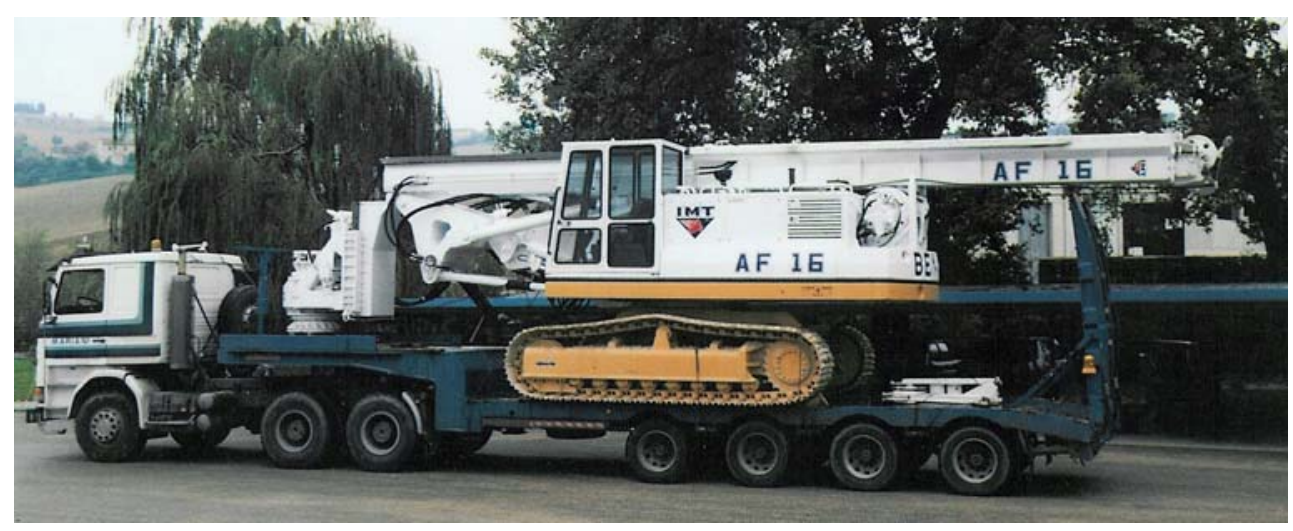

Figura 1.2 - Equipamento AF 16 na posição de transporte (IMT, 1995).

Podem ser considerados como desvantagens os seguintes itens:

- Ausência de equipamento que monitore diversos dados simultaneamente.

- Maior dificuldade de manobras em períodos chuvosos, devido à utilização de sistema de tração com utilização de pneus ao invés de esteiras. 
- Maior limitação nos diâmetros e profundidades das estacas devido aos menores torques disponíveis no cabeçote rotativo e no guincho.

- Menor produção.

\subsubsection{COMPOSIÇÃO DO EQUIPAMENTO}

O equipamento em desenvolvimento será composto basicamente dos seguintes subconjuntos:

- Plataforma.

- Motor a diesel turbo aspirado com $97 \mathrm{~kW}$.

- Torre.

- Sistema de tração.

- Direção.

- Cilindros hidráulicos de nivelamento e carregamento do equipamento.

- Hastes telescópicas

- Guinchos (principal e auxiliar).

- Sistema de empuxo axial (pull-down e pull-back).

- Cabeçote de perfuração com três velocidades.

- Sistema hidráulico.

- Alimentador de trados.

- Conjunto girador (SWIVEL) equipado com manômetro para controle das pressões de injeção de argamassa. 


\section{CAPÍTULO 2}

\section{REVISÃO BIBLIOGRÁFICA}

\subsection{INTRODUÇÃO}

Este trabalho deverá resultar no desenvolvimento de um equipamento para a execução de fundações profundas com utilização de hélices segmentadas. Esse tipo de estaca, ainda sem um nome perfeitamente definido, começa a ser reconhecido no meio geotécnico como estaca hélice segmentada.

$\mathrm{Na}$ década de 80 a empresa Wirth Latina, fabricava diversos equipamentos para fundações profundas, na cidade de São Carlos, no interior do estado de São Paulo. Embora a qualidade dos mesmos fosse inquestionável, a empresa parece ter tido dificuldades em permanecer no Brasil. É provável que os equipamentos de grande porte fabricados naquela época, não encontraram um mercado importante em nosso país.

Na década de 90, as estacas escavadas de pequenos diâmetros e os tubulões escavados mecanicamente, passaram a ser comuns nos projetos de fundações profundas, em solos não saturados, devido ao significativo desenvolvimento ocorrido nos equipamentos brasileiros, necessários à execução desses tipos de fundações.

Nessa época iniciou-se no Brasil, o desenvolvimento de equipamentos leves que fizeram muito sucesso, inicialmente no interior do estado de São Paulo e posteriormente nas capitais e em muitas cidades brasileiras.

\subsection{CONTRIBUIÇÃO BRASILEIRA AO DESENVOLVIMENTO DE PERFURATRIZES ROTATIVAS PARA EXECUÇÃO DE ESTACAS ESCAVADAS EM SOLOS NÃO SATURADOS}

Em 1983 o autor deste trabalho, iniciou o desenvolvimento de um equipamento simples para a execução de estacas escavadas de pequeno diâmetro. Esse trabalho 
resultou em patente do modelo, junto ao Instituto Nacional da Propriedade Intelectual (INPI).

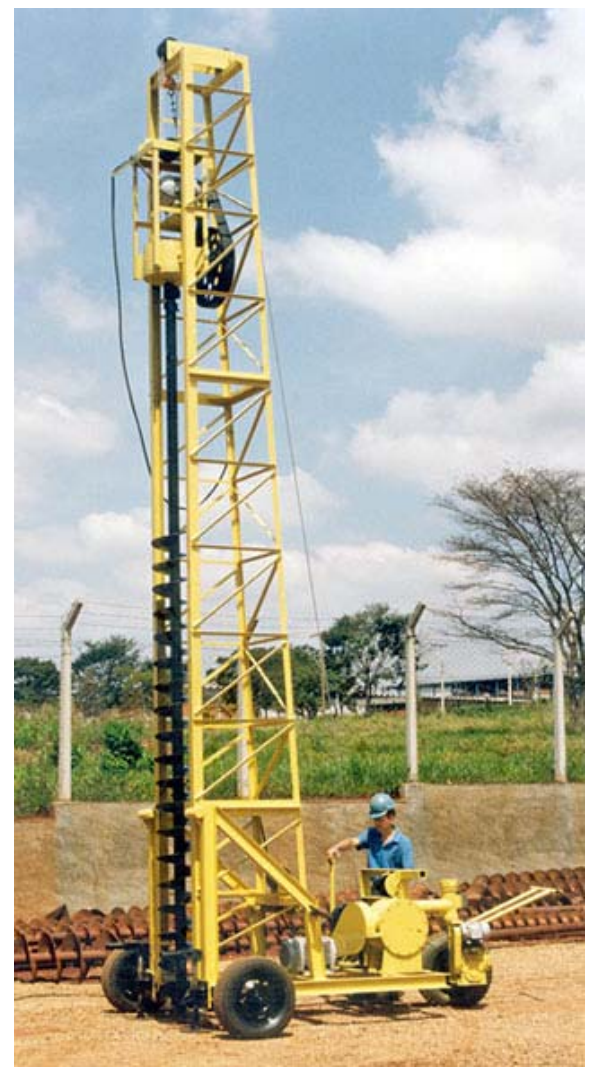

Figura 2.1 - Perfuratriz M 500

(E.G.Barreto, 1987).

O produto passou a ser fabricado e comercializado pela empresa E.G.Barreto Ltda. A perfuratriz denominada M 300, perfurava estacas com diâmetros de 20 a $30 \mathrm{~cm}$ e profundidades de até 10 metros. Posteriormente os projetos foram modificados, tornando-se possível a execução de estacas com diâmetros de até $50 \mathrm{~cm}$ e profundidades de até $12 \mathrm{~m}$. Esse novo modelo foi batizado de $\mathbf{M} 500$ (Figura 2.1), sendo líder no mercado de perfuratrizes de pequeno porte com acionamentos através de motores elétricos, até os dias de hoje. A rapidez na execução e o baixo custo de escavação das estacas, fizeram com que os trados manuais fossem praticamente abolidos das obras residenciais. Por algum tempo essas estacas foram chamadas de "estacas brocas”.

A empresa brasileira Cló Zironi, fundada em 1976, que iniciou com a comercialização de um equipamento para estacões, enveredou para o desenvolvimento de equipamentos mais leves, para a execução de estacas e tubulões.

A perfuratriz CD 27 montada sobre caminhão, pode escavar fustes com diâmetros entre 0,25 m e 1,20 m e profundidade máxima de 17 m (Figura 2). O sucesso nas vendas, deu 
grande impulso à empresa, possibilitando o desenvolvimento de uma série de outros equipamentos que até hoje estão contribuindo para a execução de fundações profundas em nosso país e até no exterior. Posteriormente, e empresa desenvolveu um modelo mais leve (Figura 2.3), para estacas e tubulões com diâmetros de até 0,80 m e profundidades de até $15 \mathrm{~m}$.

No final da década de 80 a empresa E.G.Barreto Ltda desenvolveu a linha "H" de perfuratrizes hidráulicas.

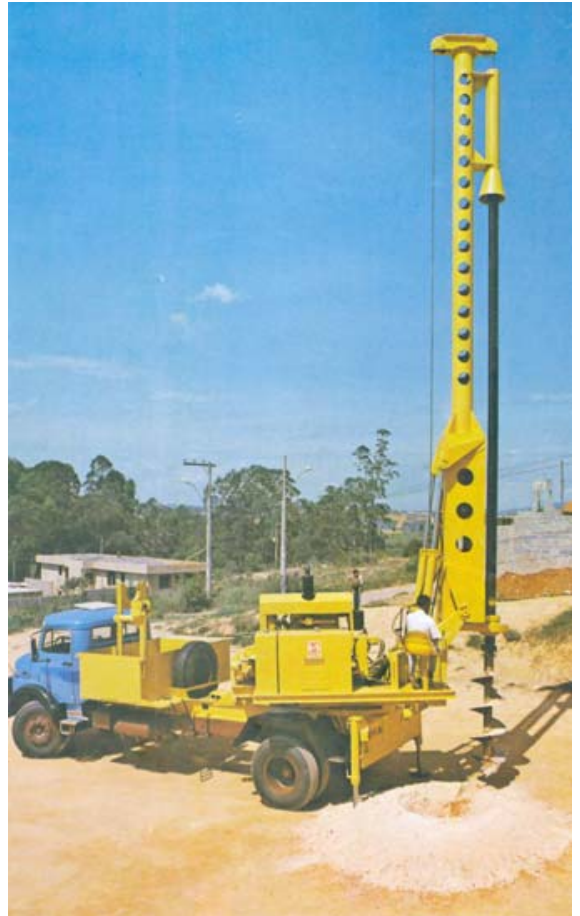

Figura 2.2 - Perfuratriz CD 27 (Cló Zironi, 198-?).

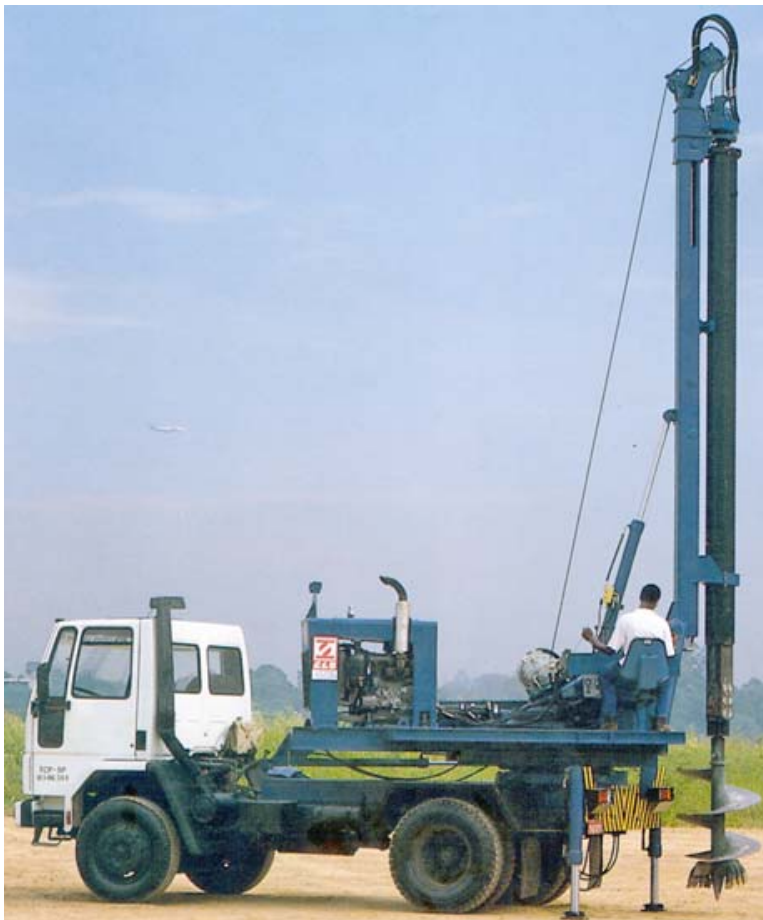

Figura 2.3 - Perfuratriz CD 17 (Cló Zironi, 199-?).

Tratava-se de equipamentos autopropelidos e sobre rodas de pneus. Foram desenvolvidos os equipamentos H 800 e H 1000 que escavavam estacas e tubulões de até $0,80 \mathrm{~m}$ e 1,00 m, respectivamente. A torre padrão permitia a escavação de até $12 \mathrm{~m}$ de profundidade, podendo ser prolongada para possibilitar a perfuração de fustes de estacas e tubulões de até no máximo 17 m (Figuras 2.4 e 2.5). Esses modelos foram muito utilizados em obras onde o acesso era praticamente impossível com equipamentos sobre caminhões (Figura 2.6). Diversas empresas de fundações tiveram a oportunidade de adquirir essas máquinas. Além de milhares de obras pequenas e médias, algumas de vulto, foram executadas com estas perfuratrizes, como, por exemplo, as fundações da cervejaria KAISER na cidade de Araraquara (Figuras 2.7 e 2.8). Esses equipamentos pesavam aproximadamente $40 \mathrm{kN}$. 


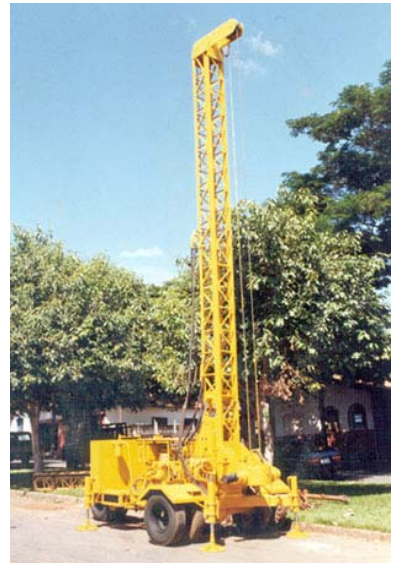

Figura 2.4 - Equipamento H 800 (E.G.Barreto, 1993).

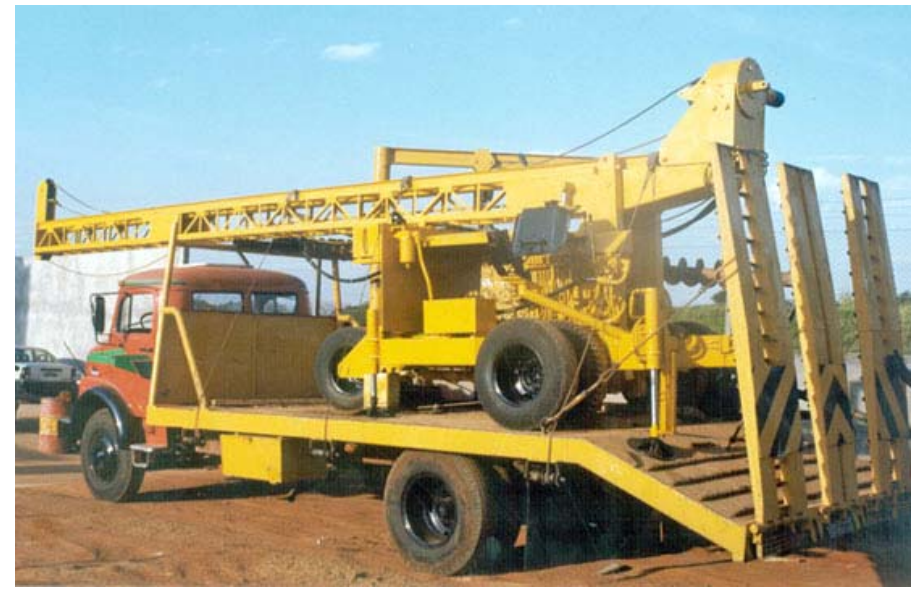

Figura 2. 5 - Perfuratriz H 800 - Posição de transporte (E.G.Barreto, 1994).

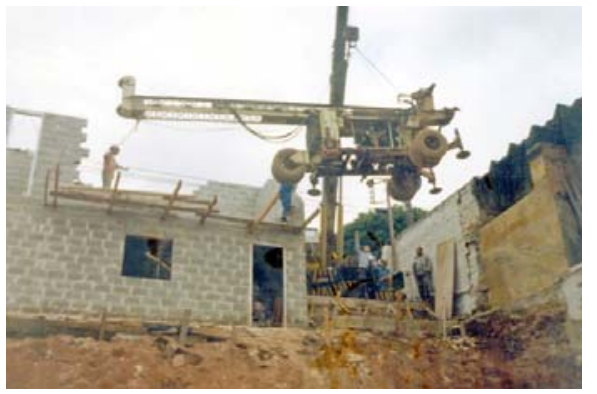

Figura2.6 - H 1000 - Implantação em obra com utilização de guindaste (E.G.Barreto, 199-?).

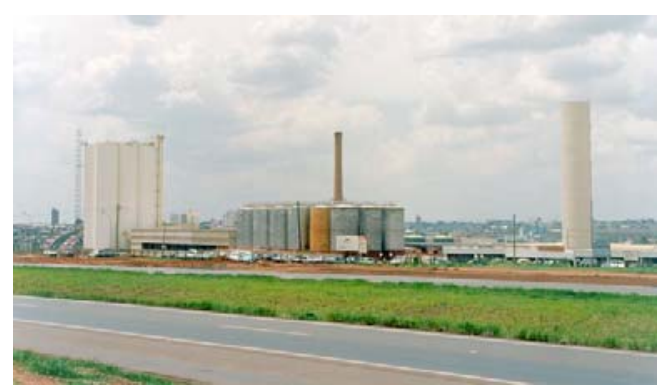

Figura 2.8 - Cervejaria KAISER ARARAQUARA Obra concluída (E.G.Barreto, 1996).

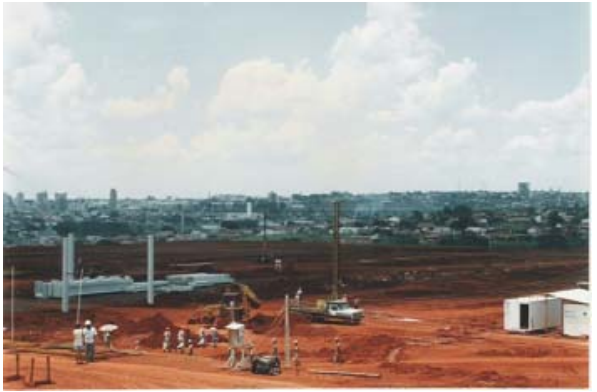

Figura 2.7 - Obra "KAISER ARARAQUARA" Utilização de perfuratrizes H 800 e H 1000 (E.G.Barreto, 1995).

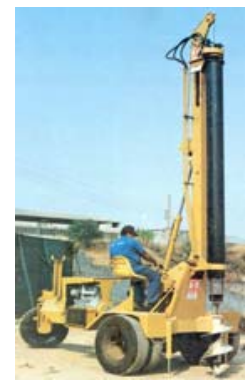

Figura 2.9 - Perfuratriz CL-07 1996). (Cló-Zironi, 199-?).

A empresa Cló Zironi também lançou um modelo de perfuratriz autopropelida, sobre rodas de pneus. O modelo batizado de CL 07 pesa aproximadamente $35 \mathrm{kN}$. Escava estacas e tubulões com diâmetros de $0,25 \mathrm{~m}$ a 0,80 $\mathrm{m}$ e profundidade máxima de $15 \mathrm{~m}$ (Figura 2.9). Em seguida, os lançamentos da E.G.Barreto para a execução de estacas e tubulões em solos não saturados foram as perfuratrizes MH 500 (Figura 2.10), $\quad$ HT 7 10 (Figura 2.11), HC 918 (Figura 2.12), HC 920 (Figura 2.13), HT 916 (Figura 2.14) e HC 916 (Figura 2.15). O equipamento MH 500 diferenciou-se dos demais por ser bastante leve $(27 \mathrm{kN})$, e pelo fato de ser uma perfuratriz composta de alguns 
acionamentos hidráulicos e outros mecânicos. Esse desenvolvimento deveu-se à forte recessão experimentada pelas empresas de fundações, no final da década de 90 e no início do novo século.

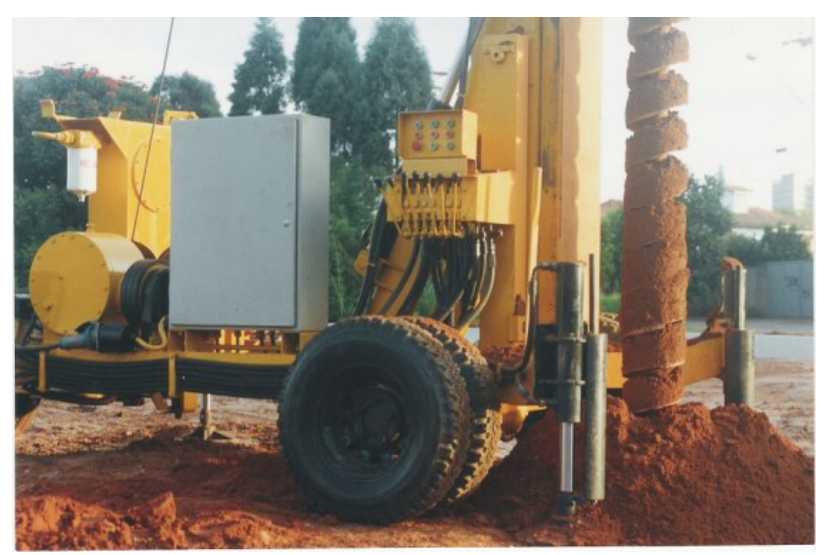

Figura 2.10 - Perfuratriz MH 500 (E.G.Barreto, 1996).

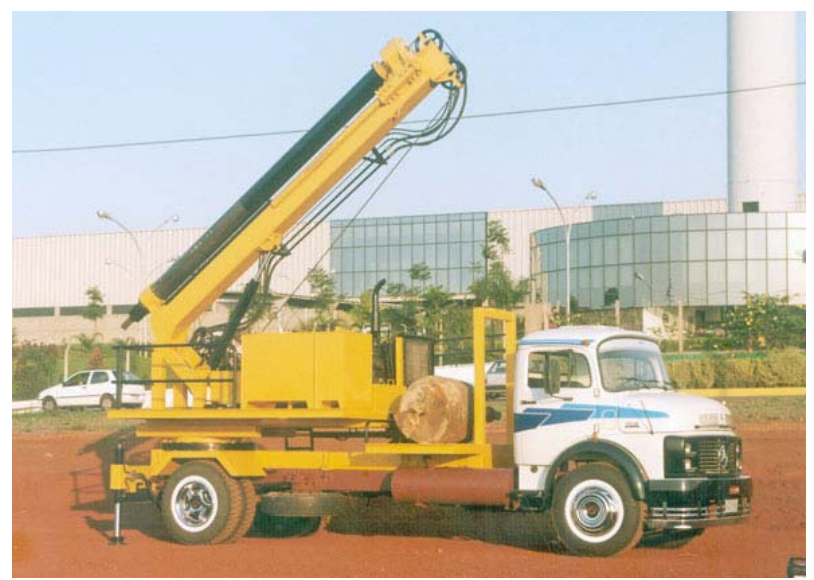

Figura 2.12 - Perfuratriz HC 918 (E.G.Barreto, 1998).
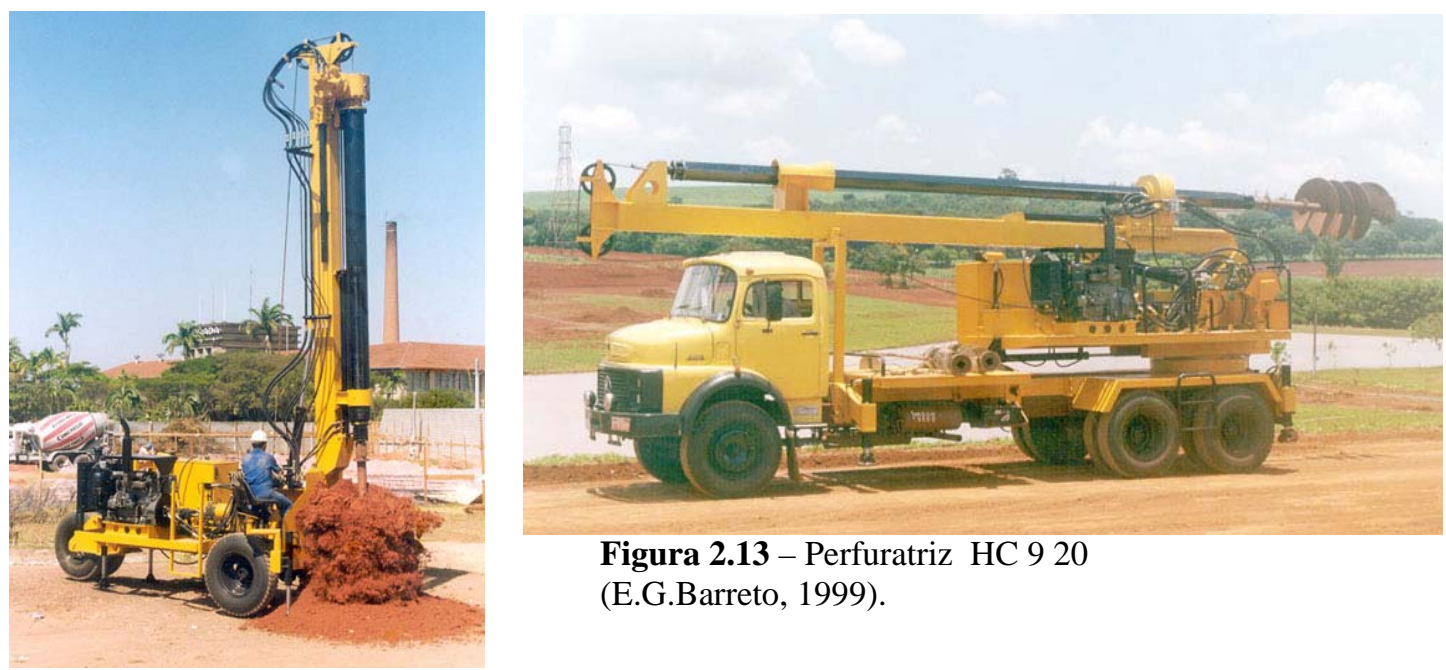

Figura 2.13 - Perfuratriz HC 920

(E.G.Barreto, 1999).

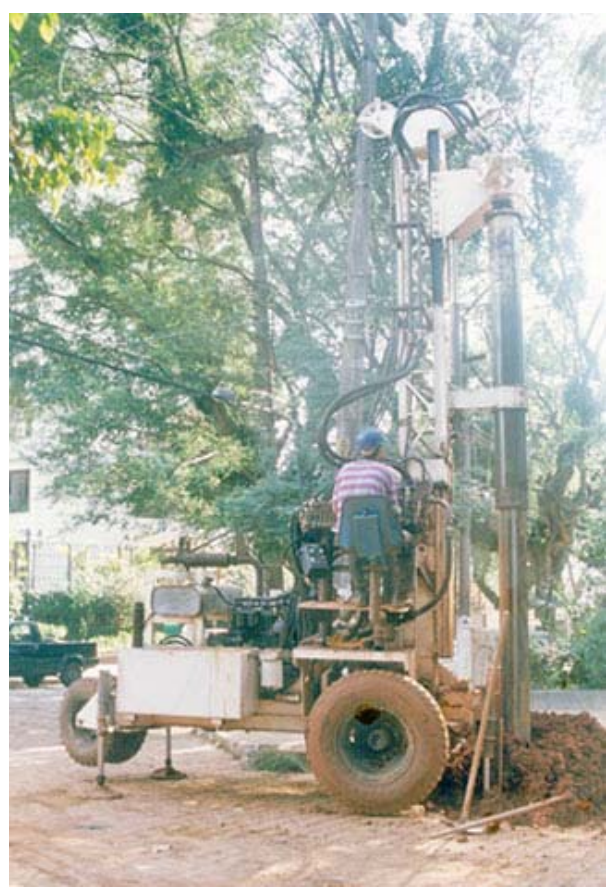

Figura 2.11 - Perfuratriz HT 710 (E.G.Bareto, 1997).

Figura 2.14 - Perfuratriz HT 916 (E.G.Barreto, 1999). 


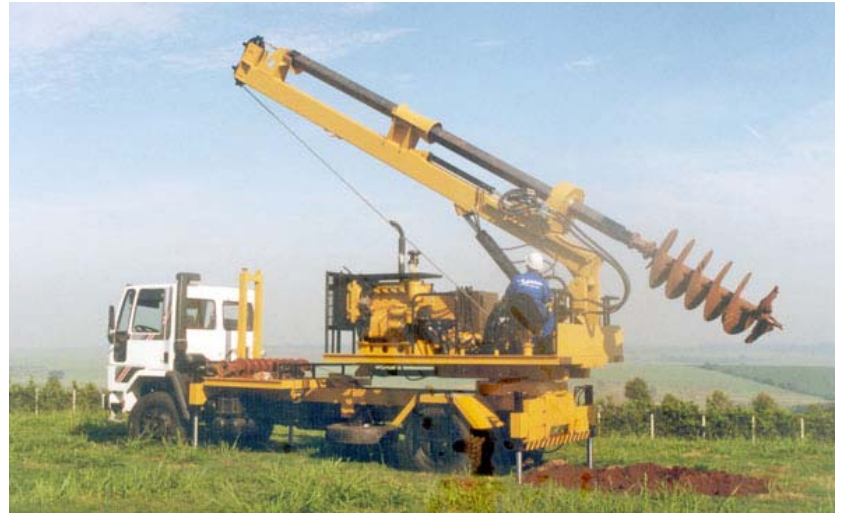

Figura 2.15 - Perfuratriz HC 916 (E.G.Barreto, 2001).

Em 2002 a empresa Cló Zironi lançou a perfuratriz modelo CD 20 com haste telescópica guiada em sua parte superior e sistema de empuxo axial que permite a perfuração de estacas inclinadas (Figura 2.16). Esse modelo permite a escavação de estacas e tubulões com diâmetros de 0,25 m a 1,00 m e profundidades de até $20 \mathrm{~m}$.

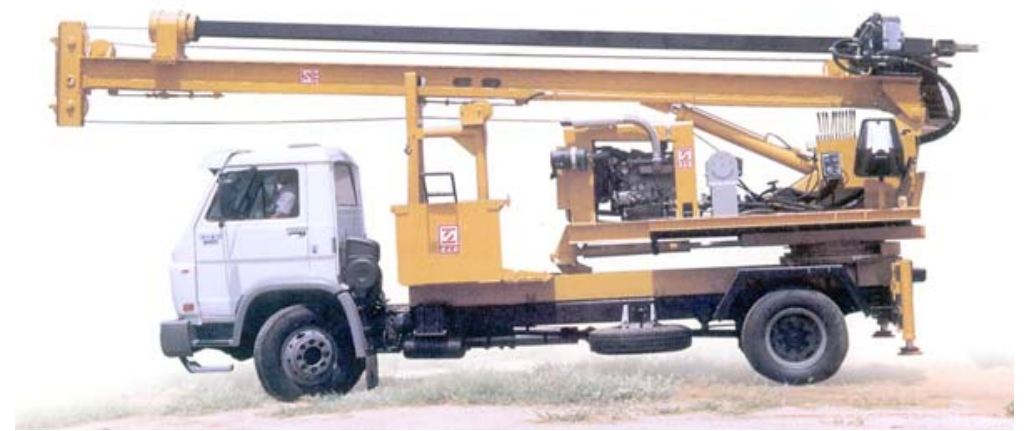

Figura 2.16 - Perfuratriz CD 20 P/PR (Cló Zironi, 2002).

Provavelmente, também devido às dificuldades econômicas das empresas pequenas e médias, a Cló Zironi desenvolveu uma perfuratriz de pequeno porte, sobre caminhão (Figura 2.17).

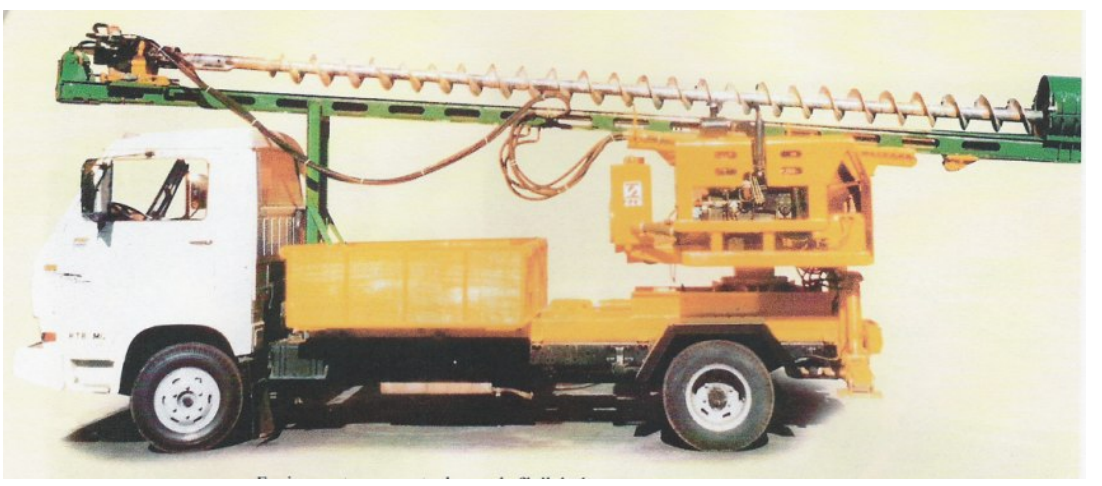

Figura 2.17 - Perfuratriz CD 12 (Cló Zironi, 2002). 
Há alguns anos a empresa BS Tubos \& Bombas Ltda iniciou a fabricação de equipamentos para fundações. A empresa, situada na cidade de Belo Horizonte, está fabricando e comercializando dois modelos de perfuratrizes hidráulicas para estacas escavadas e tubulões, em solos.

O modelo BS 1000 perfura estacas entre 0,25 m e 1,00 m de diâmetro e com comprimentos de até 20 m (Figura 2.18) e o modelo BS 1200 escava até $20 \mathrm{~m}$ de profundidade e até 1,20 m de diâmetro (Figura 2.19).

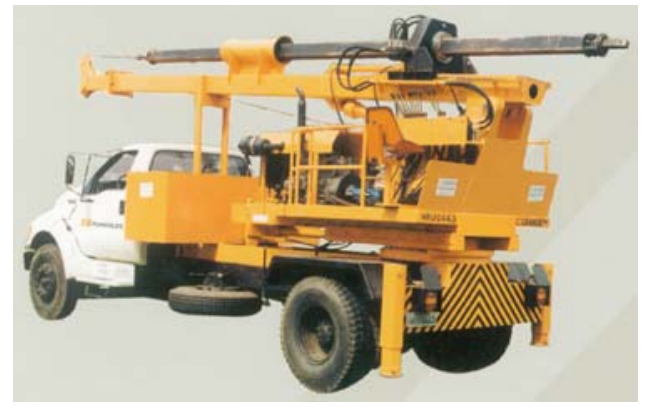

Figura 2.18 - Perfuratriz BS 1000 (BS Tubos \& Bombas, 200-?).

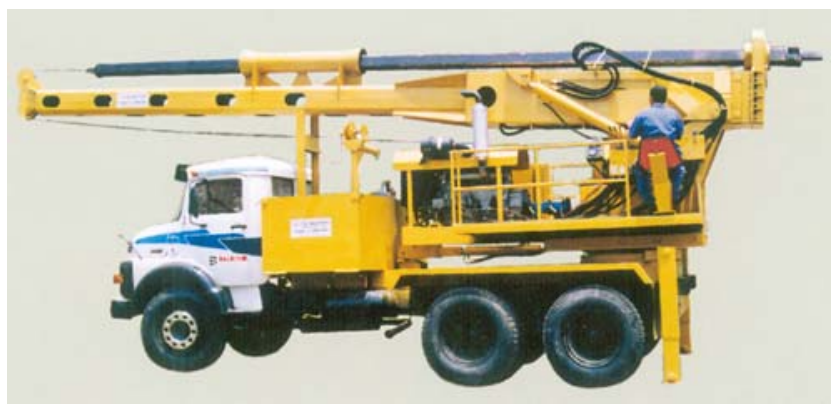

Figura 2.19 - Perfuratriz BS 1200 (BS Tubos, 200-?).

Observa-se que os equipamentos nacionais apresentados foram desenvolvidos nas duas últimas décadas. Nota-se um importante avanço tecnológico em termos de equipamentos para estacas e tubulões escavados mecanicamente em solos não saturados. Entretanto, excetuando-se os equipamentos para estacas do tipo "Raiz", o desenvolvimento de equipamentos nacionais para execução de fundações profundas através de sistema rotativo e abaixo do nível do lençol freático é muito recente.

\subsection{ESTACAS HÉLICE CONTÍNUA}

\subsubsection{HISTÓRICO}

O emprego de estacas executadas com trado contínuo (CFA: continuous flight auger) iniciou-se nos Estados Unidos na década de 50 (Penna et al., 1999). Uma mesa rotativa era adaptada a um guindaste com torre acoplada e as estacas eram executadas com diâmetros de 27,5, 30 e $40 \mathrm{~cm}$. No início da década de 70 a idéia foi introduzida na Europa e posteriormente no Japão. No Brasil as primeiras obras que utilizaram esse tipo de estaca foram realizadas em 1987. Em 1993, provavelmente devido às facilidades de importação promovidas pelo governo brasileiro, algumas empresas nacionais 
adquiriram equipamentos que possibilitaram a execução de estacas de até 1,0 m de diâmetro e comprimentos de até 25 metros (Albuquerque et al., 2001).

Os estudos realizados por Van Impe na Europa, concluíram sobre a tendência na diminuição da utilização de estacas escavadas com utilização de fluido de contenção do fuste com aumento da utilização das estacas hélice contínua (Hartikainen \& Gambini, 1991).

\subsubsection{COMPARAÇÃO COM OS TIPOS TRADICIONAIS DE FUNDAÇÕES PROFUNDAS E EVOLUÇÃO DOS EQUIPAMENTOS}

As estacas do tipo hélice contínua, apresentam as seguintes vantagens em relação às estacas mais tradicionais:

- Maior rapidez na execução resultando em elevada produtividade

- Maior facilidade de manuseio do equipamento na obra

- Ausência quase total de vibrações no terreno, comum nos equipamentos à percussão

- Menor descompressão do terreno quando comparado com as estacas escavadas

- Ausência de detritos provenientes do uso de lama bentonítica

São conhecidas e aceitas as seguintes desvantagens:

- Necessidade de terreno plano

- Central de concreto próxima à obra

- Necessidade de remoção do material escavado

- Elevada taxa de mobilização de equipamento, necessitando de quantidade importante de estacas para viabilizar a implantação do equipamento

- Limitação do comprimento da estaca, dada pelas características dos equipamentos

- Limitação do comprimento da armadura longitudinal

Os primeiros equipamentos de hélice contínua utilizavam cabeçotes de perfuração com torques que variavam entre 10 e $30 \mathrm{kNm}$. O cabeçote rotativo, mesa rotativa ou cabeçote de perfuração, são denominações diferentes para o mesmo conjunto. No início da utilização das estacas hélice contínua, o trado contínuo era adaptado no mesmo equipamento que executava estacas escavadas com uso de lama bentonítica. (Figuras 2.20 e 2.21). Atualmente utilizam-se cabeçotes rotativos que apresentam torques entre 100 e 450 kNm combinados a guinchos com capacidades de extração da hélice que variam de 50 a $500 \mathrm{kN}$. 


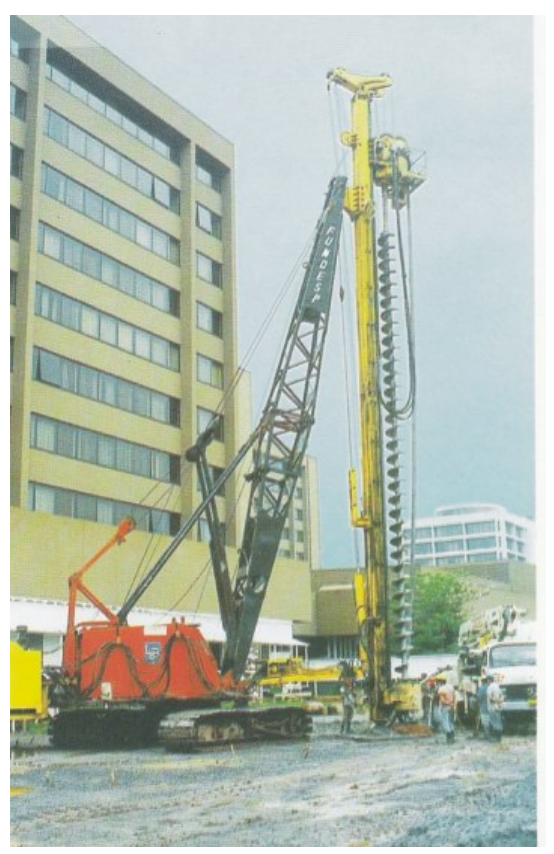

Figura 2.20 - Hélice montada em guindaste (FUNDESP, 2001).

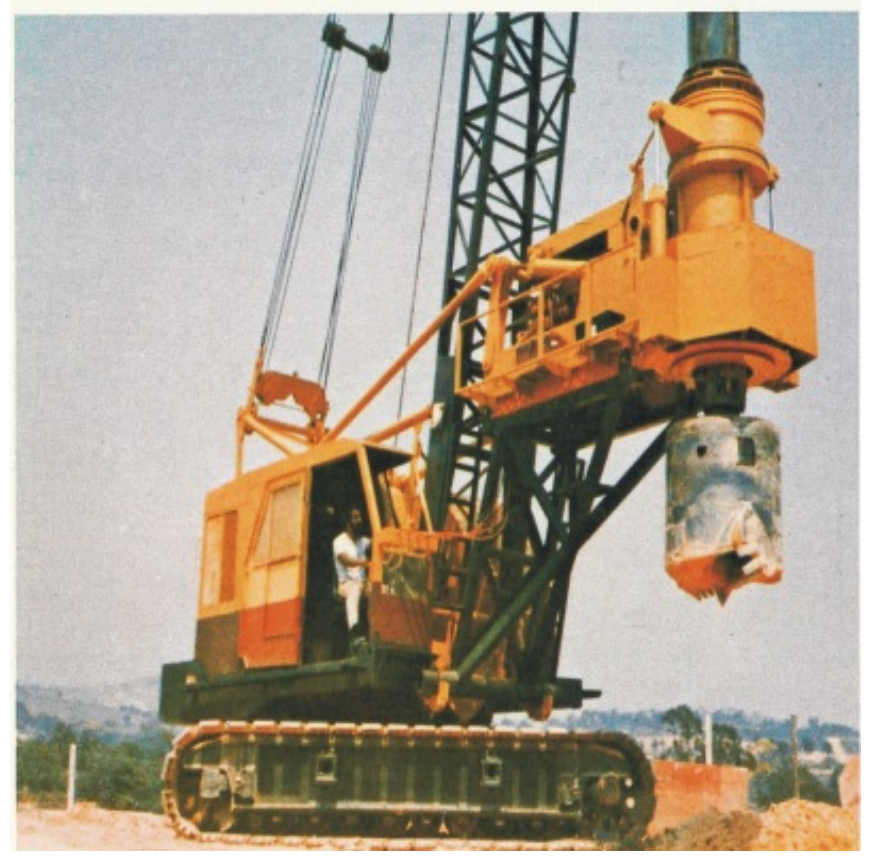

Figura 2.21 - Equipamento para estacas escavadas de grande diâmetro (Cló - Zironi, 198-?).

\subsubsection{METODOLOGIA EXECUTIVA}

A estaca hélice contínua é um tipo de estaca moldada in loco, que utiliza um trado contínuo, o qual penetra no solo através de rotação combinada com carga vertical constituída pelo peso próprio do conjunto (trado mais cabeçote rotativo). O equipamento pode ser dotado de sistema de empuxo axial; para baixo (pull-down) e para cima (pull-back). Atingida a cota de parada da estaca, a concretagem é feita através do tubo central do trado contínuo, utilizando-se uma bomba adequada. A extração do trado é feita em conjunto com a concretagem (Figura 2.22). Os equipamentos modernos são dotados de um sistema de monitoramento que registra, durante a escavação: a posição da ponta do trado em relação a um referencial adotado (superfície do terreno), a rotação, a pressão hidráulica no cabeçote rotativo e a inclinação da torre da perfuratriz, e durante a concretagem: a pressão do concreto na parte superior do tubo central, a vazão de concreto e a posição da ponta do trado em relação ao referencial adotado. A empresa JEAN LUTZ S.A. é uma das mais conhecidas no mundo, na área de instrumentação para a engenharia civil.

A Figura 2.23 mostra o instrumento, conhecido como "TARALOG”, muito utilizado nos equipamentos de hélice contínua. 


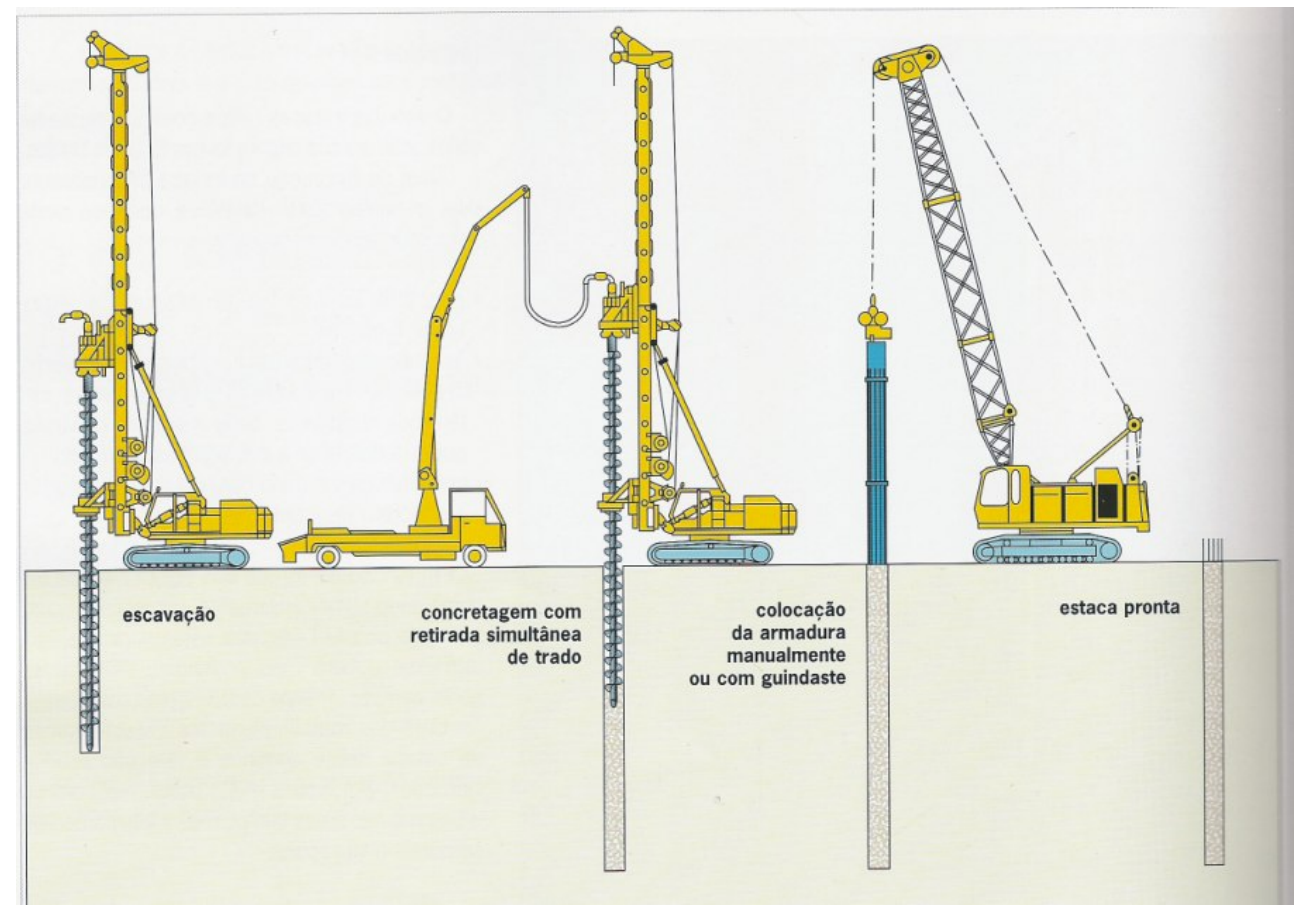

Figura 2.22 - Fases da execução da estaca hélice contínua (Brasfond - 2001).

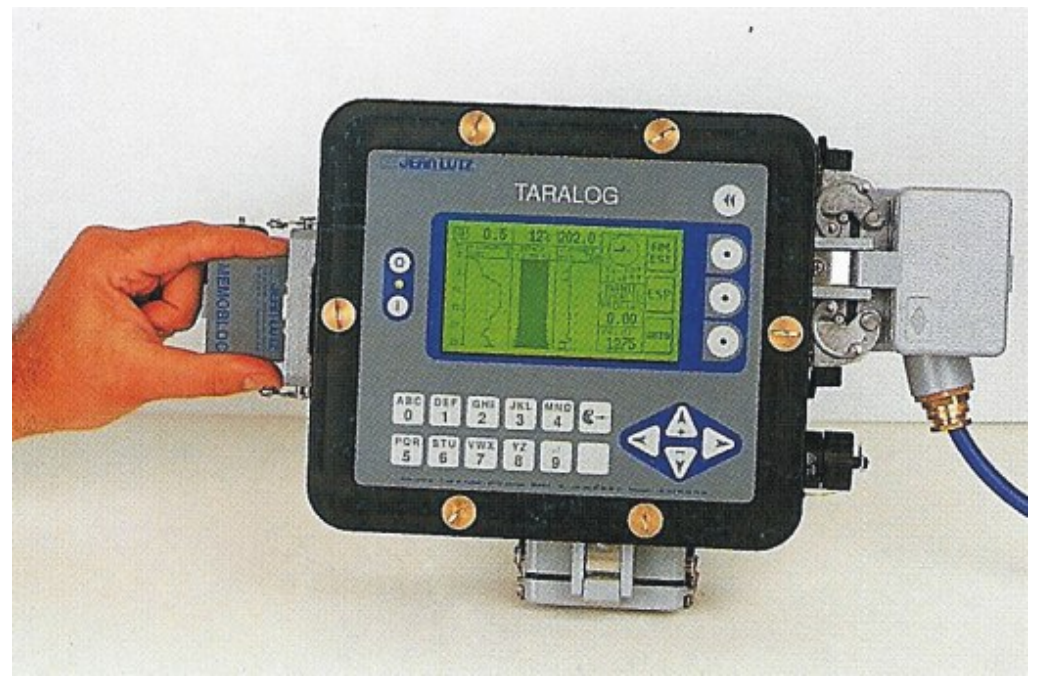

Figura 2. 23 - Parte do equipamento eletrônico de monitoramento. (JEAN LUTZ, 199_?).

Um software apropriado permite obter a partir dos dados obtidos: a velocidade de avanço e de extração do trado, o perfil teórico do fuste da estaca e o torque no trado.

(Figura 2.24).

O processo permite a execução de estacas em terrenos coesivos ou arenosos, acima ou abaixo do nível do lençol freático, já que a entrada de solo ou água é impedida por uma tampa de proteção instalada na ponta do trado. (Figura 2.25). 


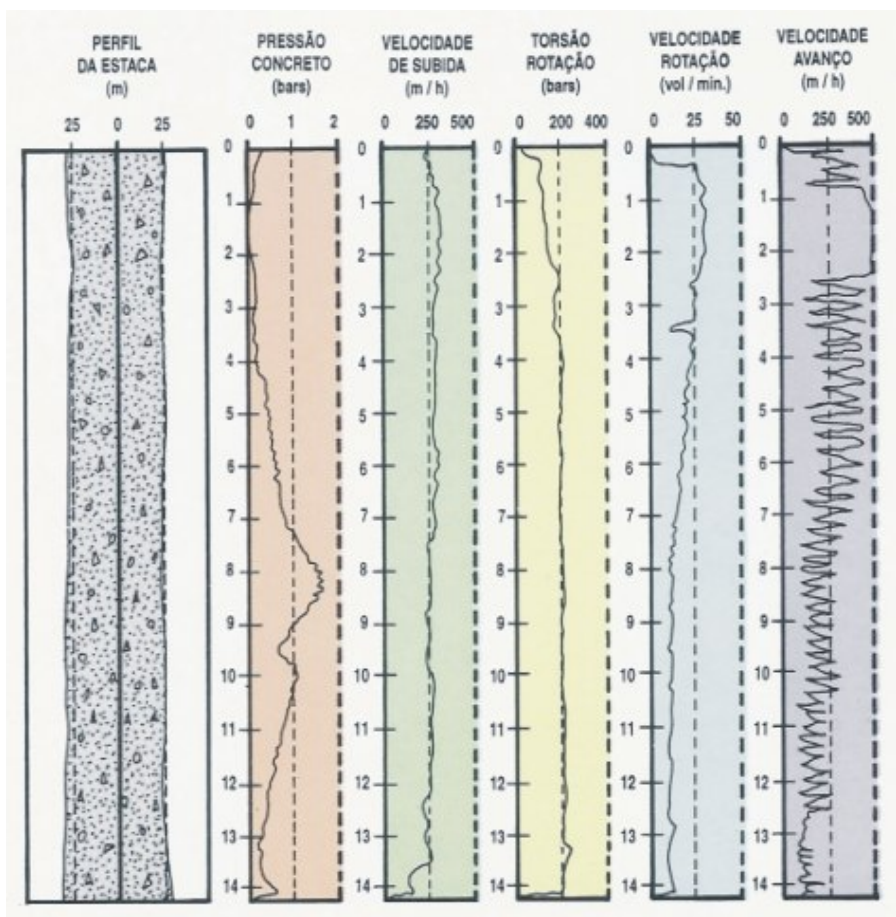

Figura 2.24 - Relatório final de monitoramento de uma estaca. (FUNDESP, 2001).

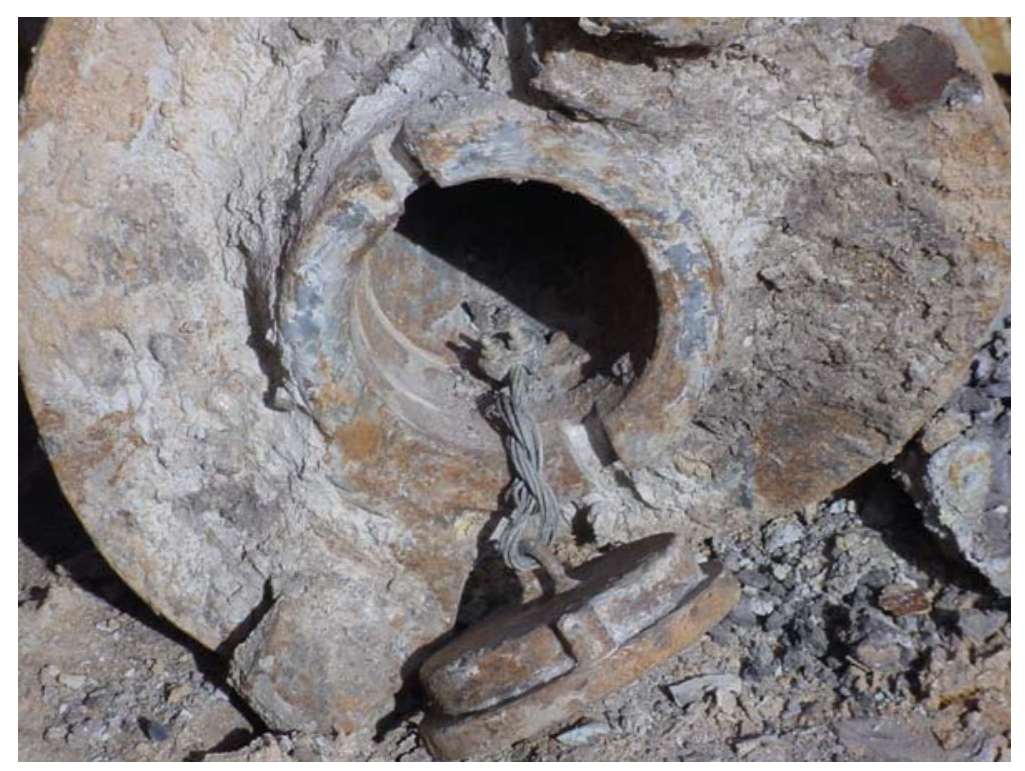

Figura 2. 25 - Detalhe da tampa de proteção da ponta da hélice (ENGESTRAUSS, 200-?).

\subsubsection{CONJUNTOS BÁSICOS}

Os primeiros equipamentos foram construídos utilizando-se guindastes sobre esteiras. A torre, cabeçote rotativo e a hélice contínua (trado) formavam um conjunto adaptado na lança do guindaste. Atualmente são projetados especificamente para a 
execução de estacas hélice contínua e basicamente são compostos dos seguintes subconjuntos:

- Esteira

- Estrutura de Suporte da torre equipada com cilindros hidráulicos

- Torre

- Unidade de força (motor a diesel)

- Sistema hidráulico

- Cabeçote de Perfuração

- Guincho Principal

- Guincho auxiliar (utilizado para manobras diversas e para colocação das armaduras)

- Cilindros hidráulicos de nivelamento

- Segmentos de trados que formam o trado contínuo

- Sistema de monitoramento eletrônico

- Sistema de limpeza da hélice (opcional)

As figuras 2.26 e 2.27, mostram equipamentos modernos

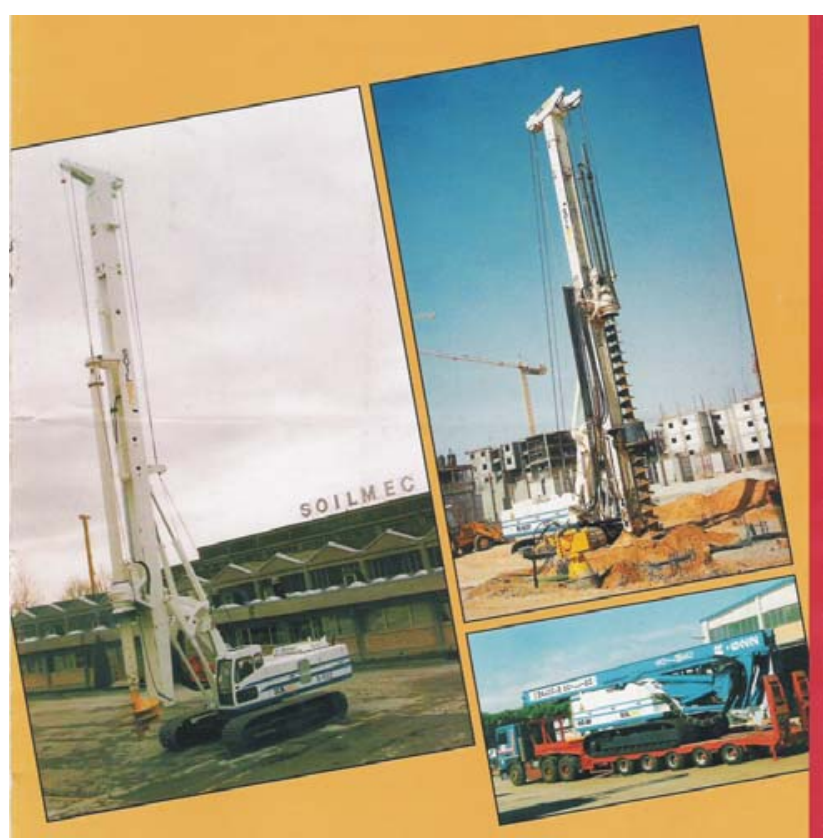

Figura 2.26 - Perfuratriz R -622 (SOILMEC, 199-?)

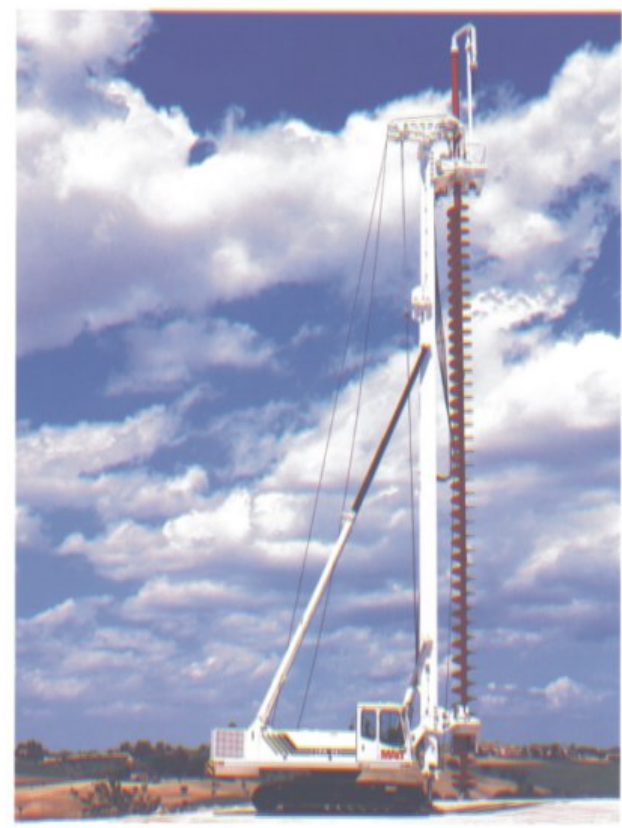

Figura 2.27 - Perfuratriz CFA-24 (MAIT, 199-?)

\subsubsection{APLICAÇÕES}

As estacas hélice contínua estão sendo aplicadas, principalmente, nos seguintes casos: 
- Nos centros urbanos, próximos de edifícios antigos, hospitais, escolas e outras edificações onde seria desaconselhável a utilização de equipamentos que viessem a produzir vibrações, ruídos excessivos ou desconfinamento do terreno.

- Em obras com quantidade elevada de estacas de mesmo diâmetro tais como indústrias de grande porte e conjuntos habitacionais. Nesses casos a elevada produtividade alcançada pelo processo, torna a aplicação muito atrativa.

- Em estruturas de contenção, principalmente em divisas com prédios existentes, quando o projeto exige estacas de grandes diâmetros, já que o cabeçote de perfuração disponibiliza escavações a distâncias a partir de $40 \mathrm{~cm}$, medidas da parede de divisa até o eixo da estaca.

\subsubsection{EQUIPAMENTOS MAIS CONHECIDOS NO BRASIL}

Existe uma variedade muito grande de equipamentos para execução de estacas hélice contínua, no mercado internacional. Os italianos parecem ser os mais arrojados nesse segmento. No Brasil, entre os fabricantes de equipamentos para fundações, o autor só tem conhecimento de um deles, que oferece equipamentos para esse tipo de estaca. Trata-se da empresa Cló Zironi, com sede em Belo Horizonte-MG.

A seguir, apresentam-se os equipamentos para a execução de estacas hélice contínua mais conhecidos no meio geotécnico brasileiro. Muitos desses equipamentos executam mais de um tipo de fundação. São os equipamentos conhecidos como multifunção. A figuras 2.28 a 2.84 mostram equipamentos cuja maioria utilizam trados curtos para a escavação de estacas ou tubulões, caçambas para a escavação de estacas de grandes diâmetros (estacões), que normalmente utilizam lama bentonítica e também trado em hélice contínua para a execução de estacas do tipo hélice contínua monitorada. Talvez o termo “monitorada” seja desnecessário já que é muito difícil executar uma estaca hélice contínua sem algum tipo de monitoramento que garanta a integridade do fuste da mesma. Esse fato deve-se à elevada relação entre a área da seção transversal da estaca e a área da seção transversal interna do tubo central do trado contínuo, por onde é feita a concretagem. É comum a utilização de tubo central com diâmetro interno de $10 \mathrm{~cm}$ para trado com diâmetro externo mínimo de $30 \mathrm{~cm}$. Nesse caso, a relação de área mencionada acima é sempre maior ou igual a nove. Para estacas com $40 \mathrm{~cm}$ de diâmetro essa relação sobe para 16 e para estacas com diâmetro de $50 \mathrm{~cm}$ o valor é de 25. Como exemplo, para uma estaca com diâmetro de $40 \mathrm{~cm}$ e 8 metros de 
profundidade, se a coluna de concreto no interior do tubo central for de $8 \mathrm{~m}$, esse volume será consumido com a extração de apenas $40 \mathrm{~cm}$ da hélice. Portanto, é fácil observar que é fundamental a existência de um sistema que controle o preenchimento integral do fuste da estaca na medida em que a hélice é extraída.

Cabe ressaltar que os trados normalmente utilizados nas perfuratrizes, não são contínuos, mas sim compostos por diversos segmentos, normalmente de 6 metros de comprimento e um de $1,50 \mathrm{~m}$ em cuja extremidade inferior ficam instalados as ferramentas de corte e a tampa de proteção. É comum o termo trado contínuo devido ao processo ser contínuo, ou seja, após a montagem inicial dos segmentos, uma hélice contínua é formada e mantida até o final da obra. É evidente que para cada diâmetro de estaca, uma nova composição deve ser montada. Em obra cujo projeto de fundações em estacas hélice contínua especifica vários diâmetros de estacas, o tempo gasto para a troca das hélices torna-se importante na produtividade e no custo do serviço.

\subsubsection{EQUIPAMENTOS SOILMEC}

\subsection{EQUIPAMENTO R - 208}

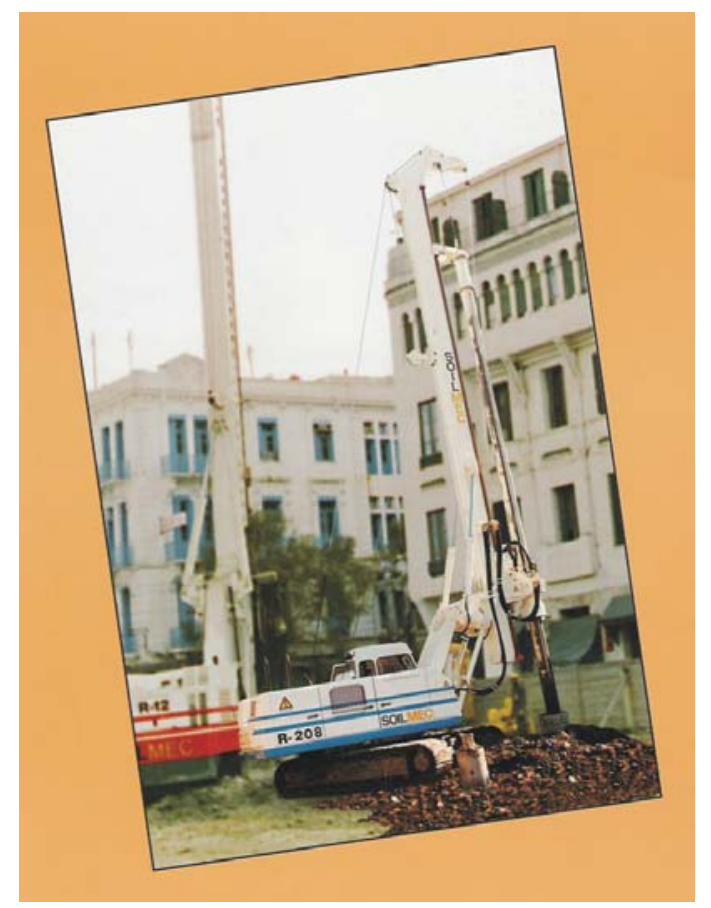

Figura 2.28 - Perfuratriz R-208 (SOILMEC, 1995).

Deve-se considerar que todos os equipamentos apresentados neste trabalho, possuem acionamentos hidráulicos, exceto a perfuratriz M 500 que é totalmente mecânica. 
Apresentam-se a seguir, fotos, desenhos e especificações técnicas dos principais produtos da empresa italiana, SOILMEC.

Esse equipamento (Figura 2.28) foi desenvolvido, com o conceito de equipamento para trabalhos em locais com pouco espaço físico (SOILMEC, 1995). Trata-se de perfuratriz montada sobre esteiras que pesa $250 \mathrm{kN}$ e disponibiliza na mesa rotativa o torque máximo de $80 \mathrm{kNm}$, possibilitando a escavação de fustes de estacas ou tubulões com até 1,20 m de diâmetro. Essas informações são válidas para escavação com utilização de trado curto. Para o Brasil, não se trata de equipamento pequeno e leve quando comparado com os equipamentos normalmente aqui utilizados nas obras com o espaço físico reduzido.

A figura 2.29 apresenta as dimensões principais da perfuratriz R 208.

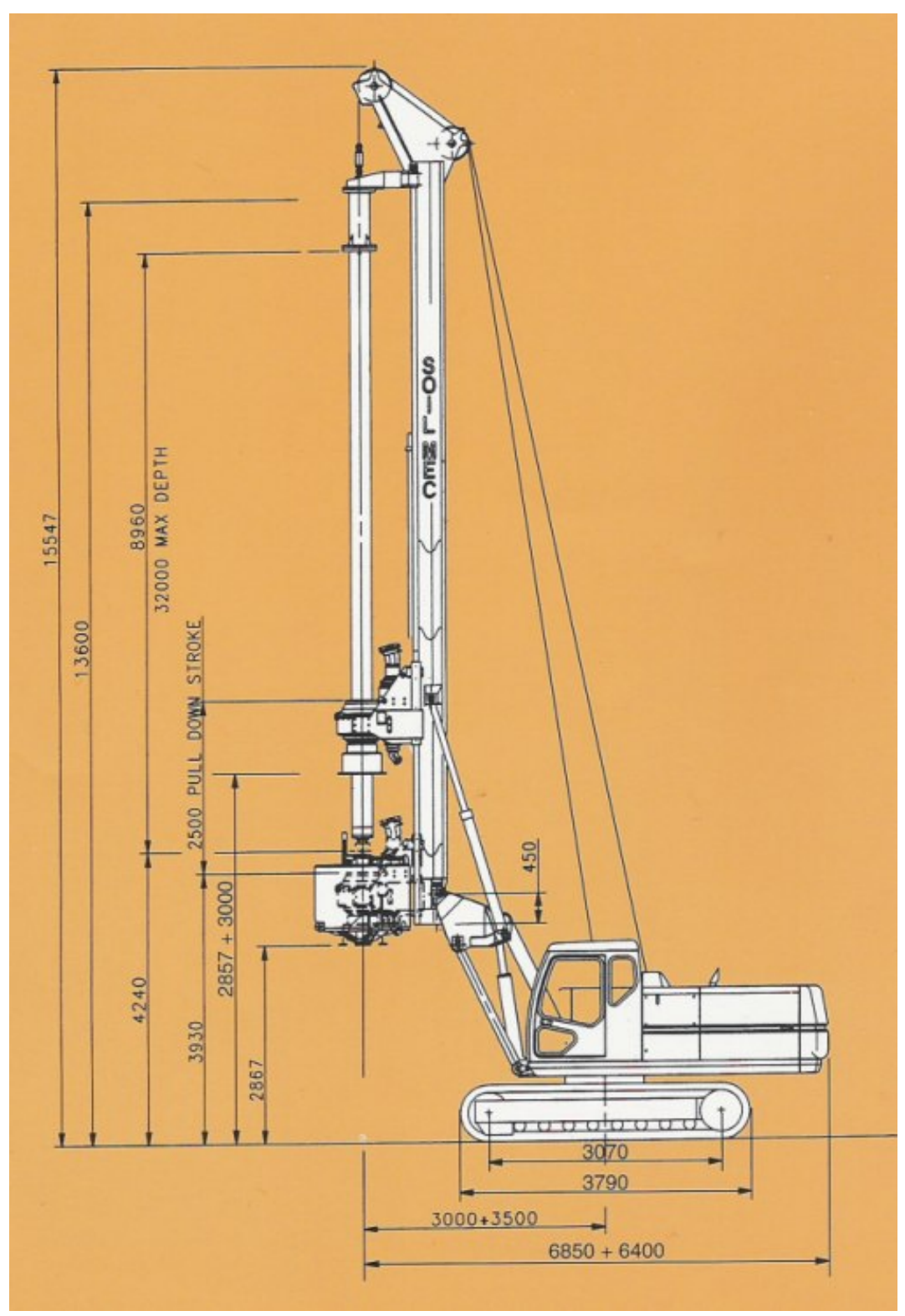

Figura 2.29 - Vista lateral da perfuratriz R 208 (SOILMEC, 1995). 
Na posição de trabalho o equipamento tem aproximadamente 15,5 m de altura e 6,85 m de comprimento e na posição de transporte seu comprimento é de 12,35 m e sua altura atinge 4,0 m quando carregado numa carreta com prancha de 0,90 m de altura (distância medida na vertical, do solo até a face superior da prancha).

A tabela 2.1 apresenta as especificações técnicas do equipamento.

Tabela 2.1 R- 208 DADOS TÉCNICOS

\begin{tabular}{|c|c|c|c|c|c|}
\hline Descrição & un & \multicolumn{3}{|c|}{ Escavada } & Hélice contínua \\
\hline Motor a diesel DEUTZ & $\mathrm{kW}$ & \multicolumn{3}{|c|}{94} & 94 \\
\hline Peso do equipamento & $\mathrm{kN}$ & \multicolumn{3}{|c|}{250} & 250 \\
\hline Diâmetro máximo da estaca & $\mathrm{m}$ & \multicolumn{3}{|c|}{1,20} & 0,70 \\
\hline Profundidade máxima de escavação & $\mathrm{m}$ & \multicolumn{3}{|c|}{40,00} & 15,00 \\
\hline Torque nominal na mesa rotativa & $\mathrm{kNm}$ & \multicolumn{3}{|c|}{80,0} & 80,0 \\
\hline Velocidade de descarga & rpm & \multicolumn{3}{|c|}{150} & \#\#\# \\
\hline Rotações no eixo de saída da mesa de giro & rpm & \multicolumn{3}{|c|}{7,6} & $* * *$ \\
\hline Tração em uma linha do guincho principal & $\mathrm{kN}$ & \multicolumn{3}{|c|}{80} & 80 \\
\hline Tração em quatro linhas do guincho princ. & $\mathrm{kN}$ & \multicolumn{3}{|c|}{320} & 320 \\
\hline Tração em uma linha do guincho auxiliar & $\mathrm{kN}$ & \multicolumn{3}{|c|}{35} & 35 \\
\hline Velocidade de extração & $\mathrm{m} / \mathrm{min}$ & \multicolumn{3}{|c|}{$* * *$} & $* * *$ \\
\hline \multirow{2}{*}{ Dimensões durante o transporte } & \multirow[t]{2}{*}{$\mathrm{m}$} & Comp & Larg. & Alt. & $* * *$ \\
\hline & & 12,35 & 2,50 & 4,00 & $* * *$ \\
\hline
\end{tabular}

*** Valores não informados no catálogo do fabricante \#\#\# Item inválido para a aplicação

A perfuratriz R-208 dispõe de sistema expansivo nas esteiras rodantes, que é utilizado apenas na obra, para garantir maior estabilidade ao conjunto.

No caso de aplicação para estacas escavadas o equipamento dispõe de um cilindro de empuxo axial (pull-down), com curso de $3 \mathrm{~m}$.

As Figuras 2.30 e 2.31 mostram o sistema que permite o avanço ou o recuo da torre, sem movimentação da esteira. Esse mecanismo é conhecido como "sistema paralelograma” e é movimentado por três cilindros hidráulicos sendo dois superiores e um inferior. O cilindro inferior é responsável pela movimentação da torre e os dois 
cilindros superiores, além de garantir a estabilidade da torre, são acionados automaticamente por um sistema eletrônico de forma a manter a torre na vertical. Esse recurso é extremamente interessante em termos de funcionalidade.

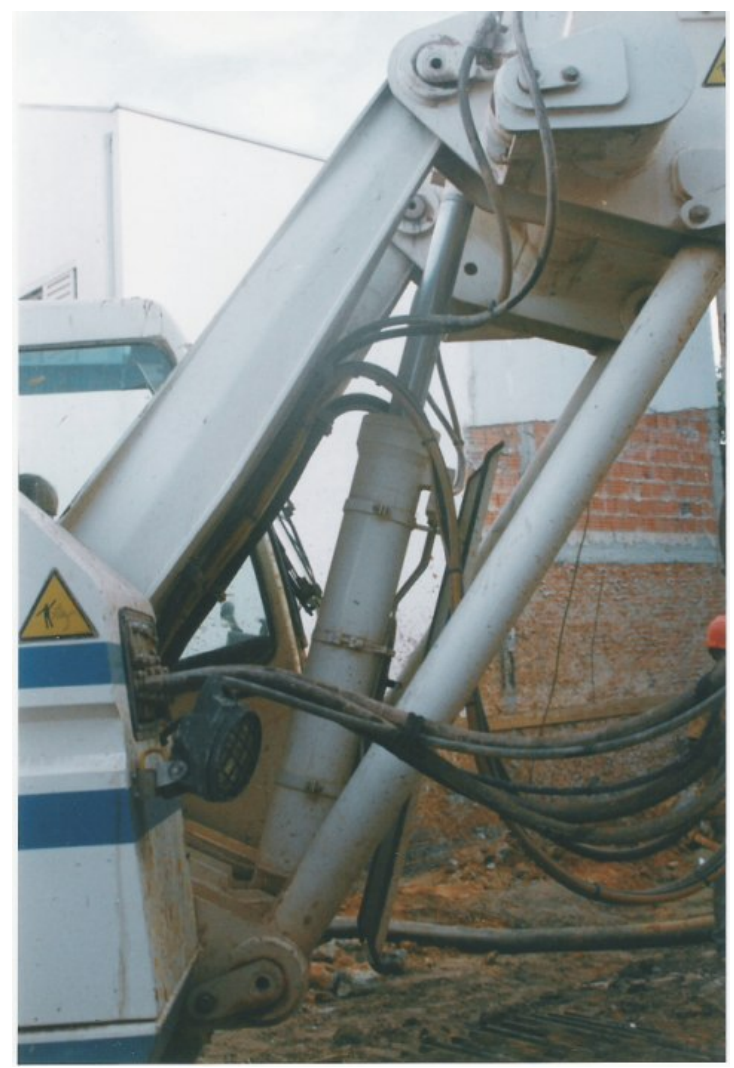

Figura 2.30 - Vista da estrutura em paralelograma.

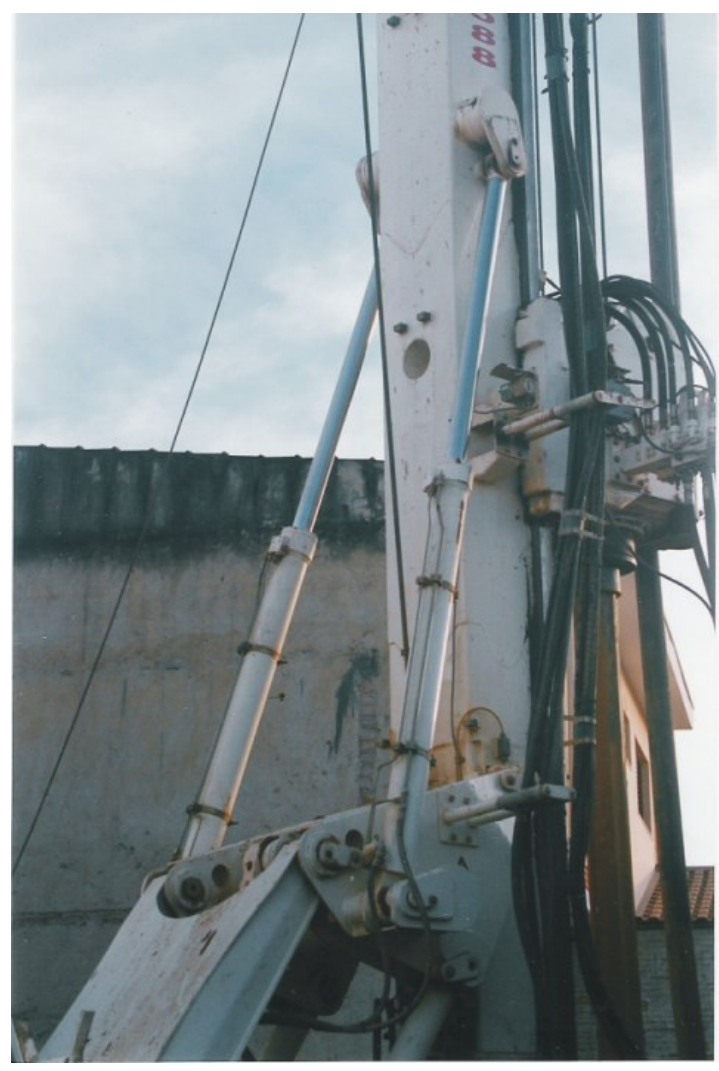

Figura 2.31 - Vista dos cilindros superiores da torre.

A Figura 2.32 mostra a mesa rotativa em operação, em posição próxima à parte inferior da torre. Nessa condição, a ponta da hélice está praticamente na cota de apoio da estaca e o caminhão betoneira já deve estar preparado para iniciar o bombeamento de concreto.

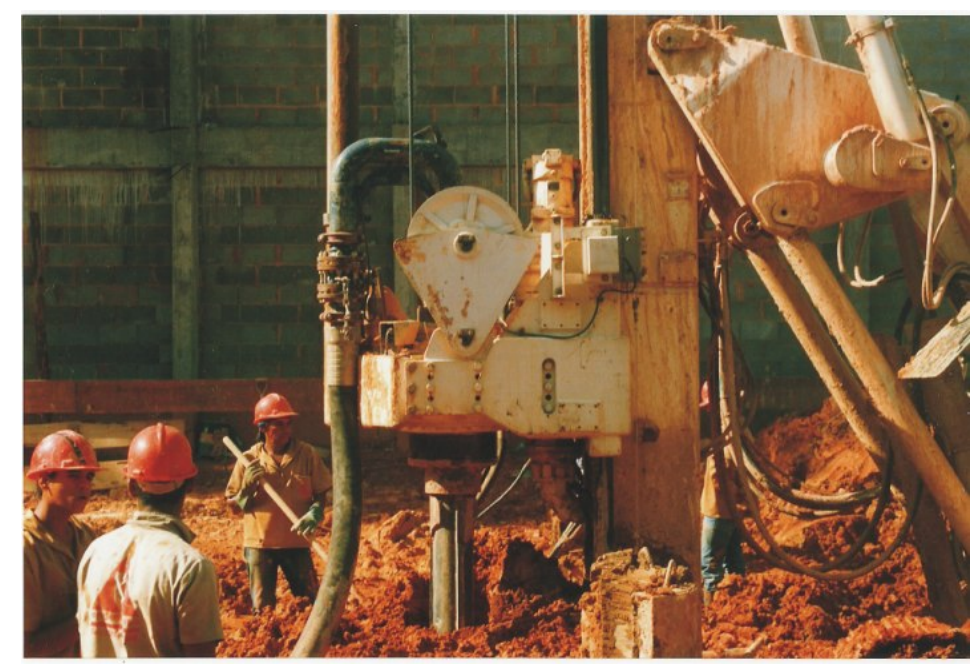

Figura 2.32 - Perfuratriz R 208 - Vista da mesa rotativa. 
$\mathrm{Na}$ linha de concretagem, entre a mangueira e o tubo curvo que é acoplado ao dispositivo girador (swivel), pode-se visualizar o dispositivo medidor da vazão de concreto.

O equipamento montado sobre esteiras é muito eficiente, principalmente em períodos chuvosos (Figura 2.33), embora o custo das esteiras rodantes seja elevado.

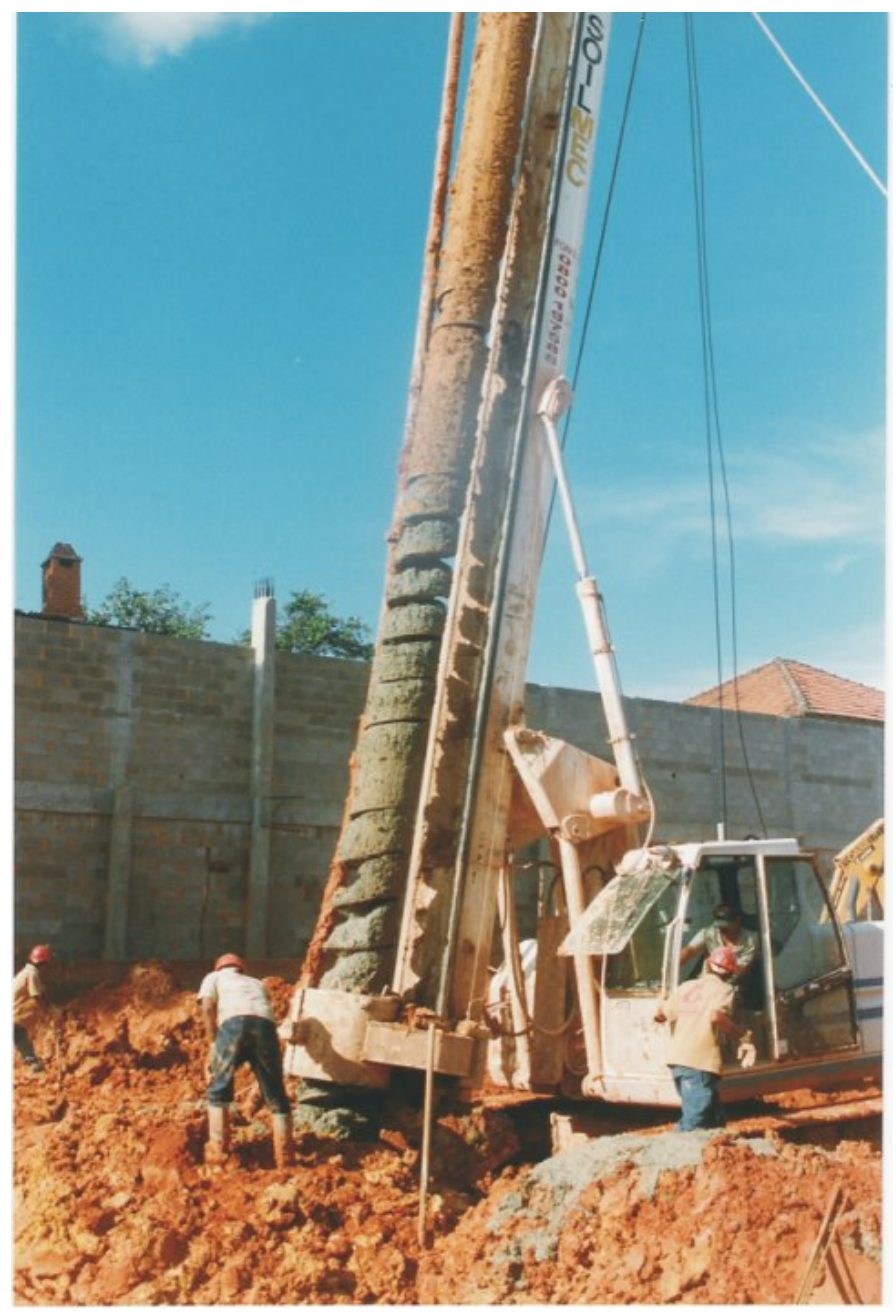

Figura 2.33 - Vista das condições do terreno e concreto envolvendo a hélice, após a concretagem.

Na Figura 2.33 pode-se notar também que o concreto que ficou envolvido na parte inferior da hélice, no término da concretagem. Esse fato ocorre devido às pressões de injeção durante a concretagem, que embora aumente o consumo de concreto na medida em que são mais elevadas, deve ser encarado de forma positiva, já que é mais um indicador de que não deve ter havido contaminação do concreto pelo solo da ponta da estaca. É evidente que esse indicador de maneira alguma substitui o monitoramento que é feito ao longo do fuste da estaca. 


\subsection{EQUIPAMENTO $\mathrm{CM}-48$}

A perfuratriz CM-48 não necessita de guindaste, como equipamento auxiliar para sua montagem. Após a saída do equipamento da carreta, o tempo para que o mesmo fique pronto para operar é de aproximadamente 25 minutos. O conceito básico do equipamento está no seu desenho, que permite as seguintes opções:

- Estacas hélice contínua

- Estacas cravadas

- Drenos

- Estacas vibradas

- Jet-Grouting

- Estacas tubadas por vibração

A torre de seção quadrada é provida de guias nas quatro faces, possibilitando as combinações acima descritas.

O conjunto rodante de esteiras tem largura variável de 2,50 m a 4,00 m. Essa característica confere ao equipamento a vantagem de aliar a facilidade de transporte em carreta comum (sem excesso lateral), com o importante acréscimo na estabilidade, durante as fases de execução dos serviços. Esse sistema rodante, sob o equipamento, pode assumir larguras variáveis entre $2,50 \mathrm{~m}$ e 4,00 m, acionando-se os cilindros hidráulicos de um ou de ambos os lados, permitindo que o equipamento opere em espaços limitados, próximo a edifícios existentes e em obras com considerável congestionamento de materiais e outros equipamentos (SOILMEC, catálogo, 199-?).

A Figura 2.34 mostra a mesa rotativa do equipamento e a Figura 2.35, o interior da cabine de operação. Nas Figuras 2.36 e 2.37 são apresentadas, respectivamente, a perfuratriz com o trado contínuo e as dimensões principais para a opção em hélice contínua e a Figura 2.38 mostra o equipamento executando uma estaca tubada. A torre tem seção transversal de 0,50 x $0,50 \mathrm{~m}$, com enrijecimento interno. A haste de prolongamento, também chamada de prolonga, aumenta em $4675 \mathrm{~mm}$ a altura do equipamento, no entanto, a vantagem desse sistema é que o cabeçote de perfuração permanece em posição mais baixa, o que tem uma importante contribuição na estabilidade do equipamento.

Na Figura 2.39 vê-se um acessório bastante eficiente durante o processo de execução das estacas hélice continua, que é o limpador de trado. 
Esse conjunto é composto de uma parte estrutural metálica e outra hidráulica.

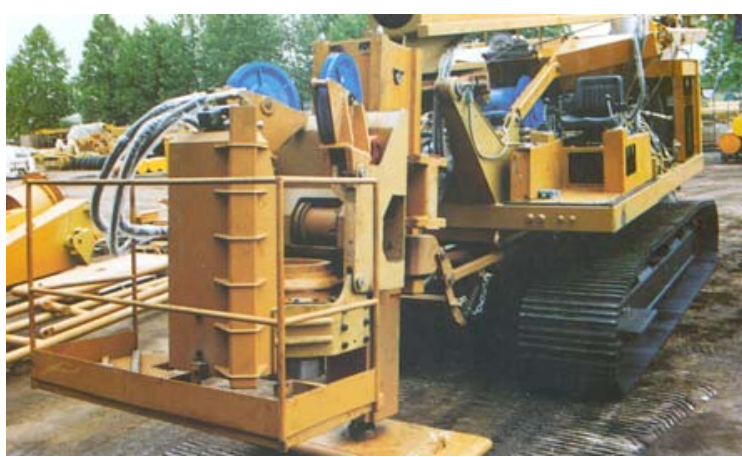

Figura 2.34 - Perfuratriz CM-48 - vista da mesa rotativa (SOILMEC, 199-?).

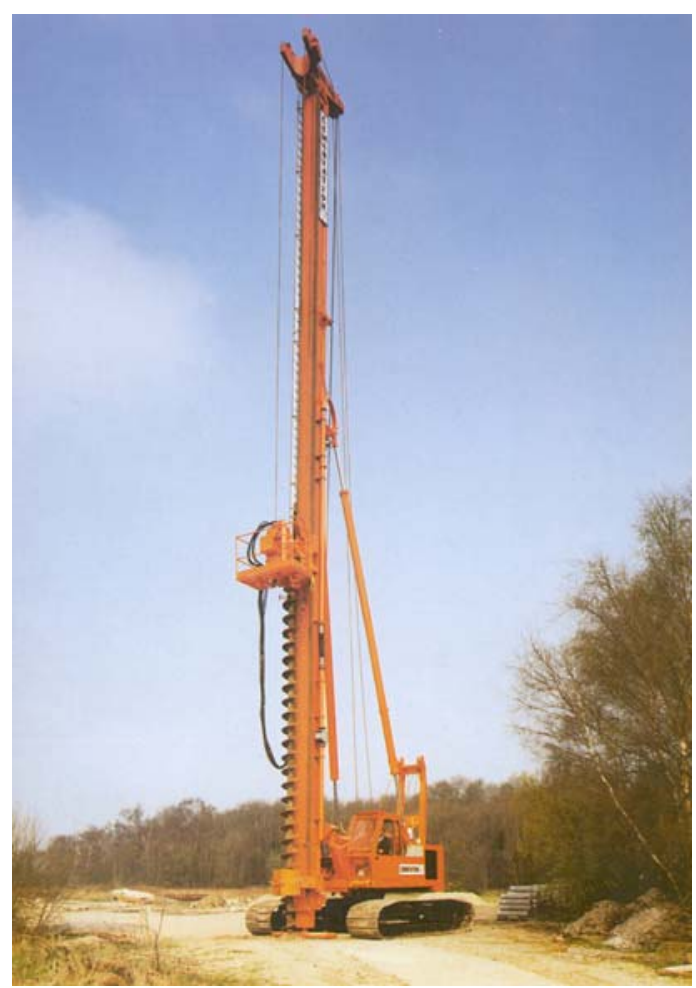

Figura 2.36 - CM-48 Vista geral do equipamento (SOILMEC, 199-?).

Na fase de extração da hélice em conjunto com a concretagem, o motor hidráulico do limpador é acionado de forma que uma lâmina de aço promove a limpeza do solo que

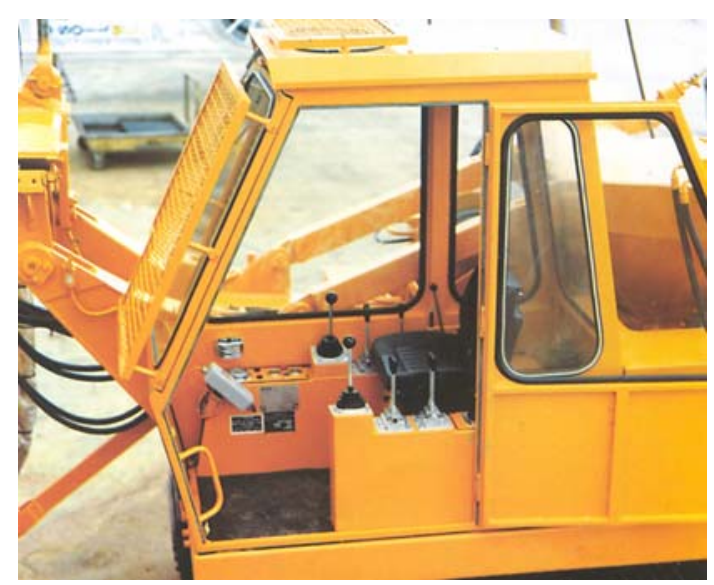

Figura 2.35 - CM-48 - Vista da cabine de operação - (SOILMEC, 199-?).

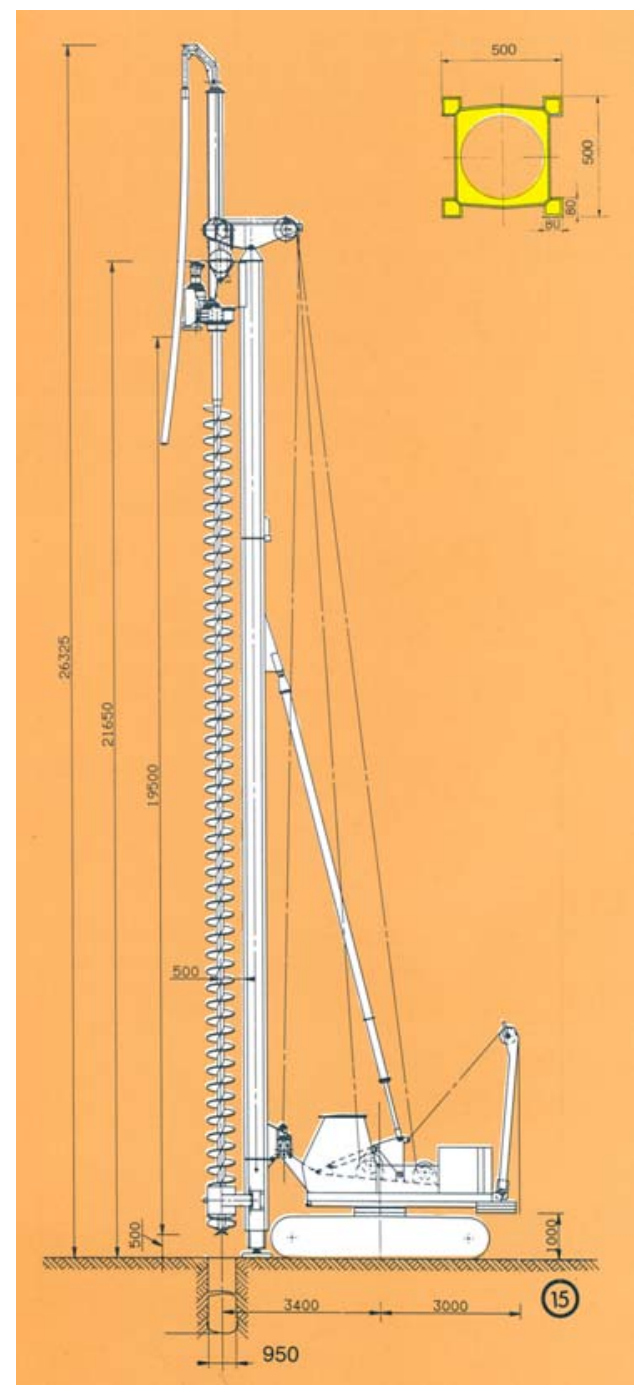

Figura 2.37- CM-48 - Dimensões principais (SOILMEC, 199-?). 
envolve o tubo central, ao girar e se deslocar na direção vertical.

Tabela 2.2 CM-48 DADOS TÉCNICOS

\begin{tabular}{|c|c|c|c|c|}
\hline Descrição & un & \multicolumn{2}{|r|}{ Escavada } & Hélice contínua \\
\hline Motor a diesel GM-4/53 TURBO & $\mathrm{kW}$ & \multicolumn{2}{|r|}{136} & 136 \\
\hline Peso do equipamento & $\mathrm{kN}$ & \multicolumn{2}{|r|}{350} & 350 \\
\hline Diâmetro máximo da estaca & $\mathrm{m}$ & \multicolumn{2}{|r|}{$* * *$} & 0,90 \\
\hline Profundidade máxima de escavação & $\mathrm{m}$ & \multicolumn{2}{|r|}{$* * *$} & $19,5+4,0$ \\
\hline Torque nominal na mesa rotativa & $\mathrm{kNm}$ & \multicolumn{2}{|r|}{88,5} & 88,5 \\
\hline Velocidade de descarga & rpm & \multicolumn{2}{|r|}{$* * *$} & \#\#\# \\
\hline Rotações no eixo de saída da mesa de giro & rpm & \multicolumn{2}{|r|}{$8-30$} & $8-30$ \\
\hline Tração em uma linha do guincho principal & $\mathrm{kN}$ & \multicolumn{2}{|r|}{80} & 80 \\
\hline Tração em quatro linhas do guincho princ. & $\mathrm{kN}$ & \multicolumn{2}{|r|}{320} & 320 \\
\hline Tração em uma linha do guincho auxiliar & $\mathrm{kN}$ & \multicolumn{2}{|r|}{33} & 33 \\
\hline Velocidade de extração & $\mathrm{m} / \mathrm{min}$ & \multicolumn{2}{|r|}{$43-85$} & 110 \\
\hline \multirow{2}{*}{ Dimensões durante o transporte } & \multirow[t]{2}{*}{$\mathrm{m}$} & Comp & Larg. & $* * *$ \\
\hline & & 16 & 3,1 & $* * *$ \\
\hline
\end{tabular}

*** Valores não informados no catálogo do fabricante

\#\#\# Item inválido para a aplicação

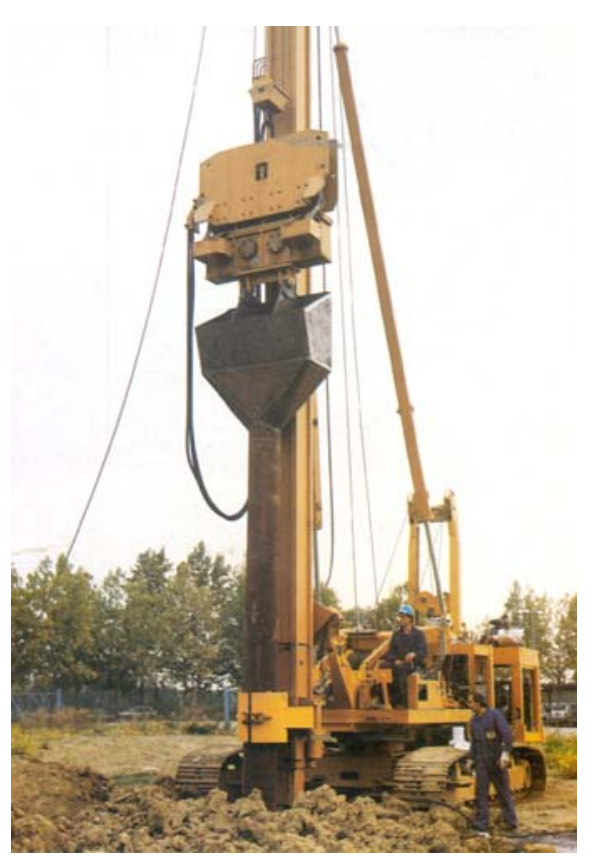

Figura 2.38 - CM-48 - Execução de estaca tubada

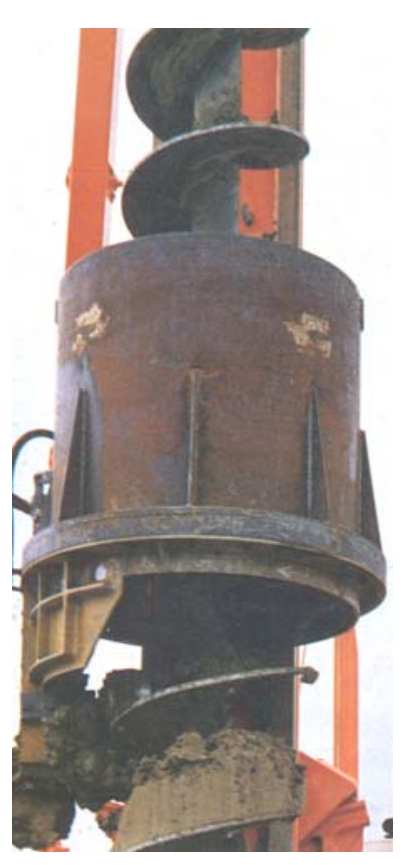

Figura 2.39 - CM-48 - Limpador de trado 


\subsection{EQUIPAMENTO R-622}

A perfuratriz R-622, assim como a $\mathbf{C M - 4 8 , ~ n a ̃ o ~ n e c e s s i t a ~ d e ~ g u i n d a s t e , ~ c o m o ~}$ equipamento auxiliar para sua montagem.

Permite as seguintes opções de serviços:

- Estacas hélice contínua

- Paredes diafragma

- Estacas escavadas com revestimento recuperável

- Estacas tubadas por vibração

- Estacas escavadas de grande diâmetro a seco ou com utilização de lama bentonítica

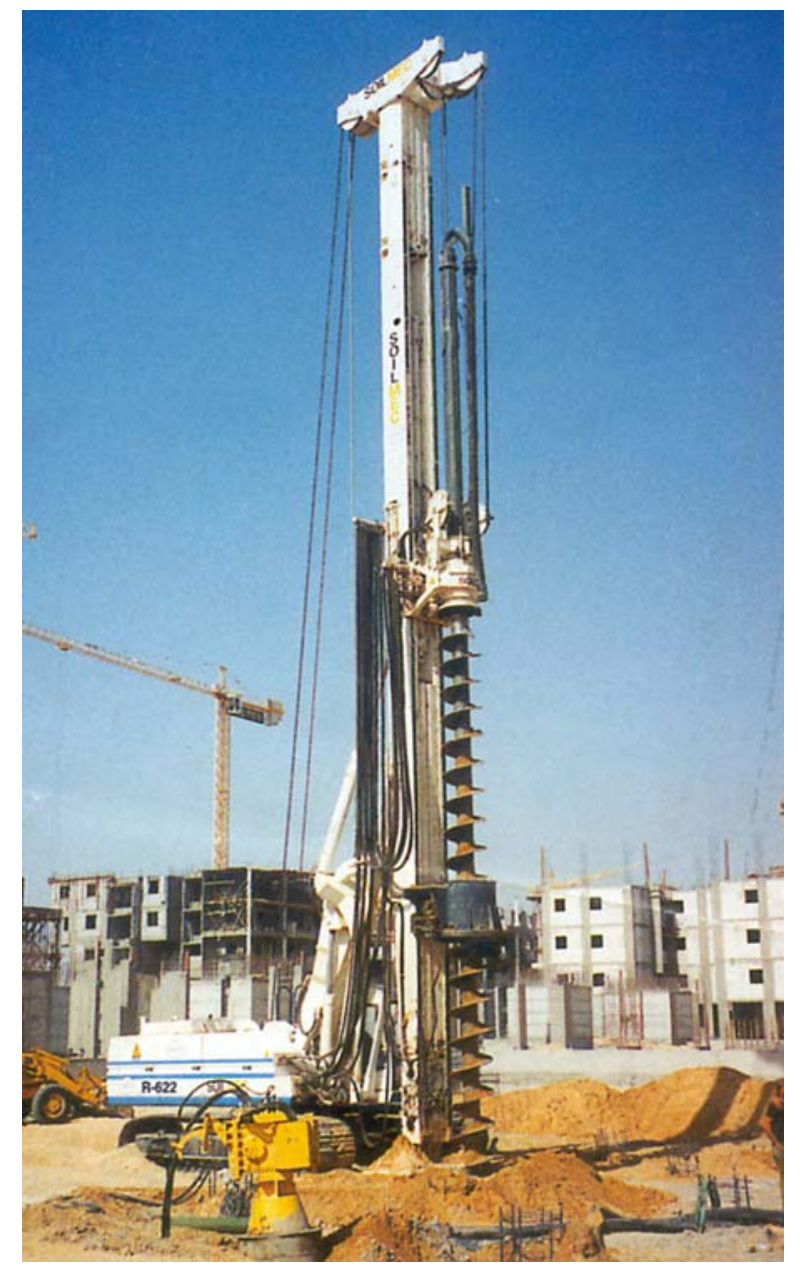

Figura 2.40 - R-622 - Execução de estacas hélice contínua.

O conjunto rodante de esteiras é classe D7 e tem largura variável. O fabricante não informa em seu catálogo, as dimensões, mínima e máxima. Como já mencionado, essa característica é bastante interessante. O sistema paralelogramo de avanço da torre, também está presente na R-622. A mesa de giro movimenta-se no sentido horário e anti- 
horário, $360^{\circ}$. Trata-se de mais um equipamento seguro e confiável, da renomada empresa SOILMEC.

A Figura 2.40 mostra uma vista genérica do equipamento, executando estacas hélice contínua monitorada. As Figuras 2.41, 2.42, 2.43 e 2.44 são vistas laterais do mesmo equipamento, porém com aplicações diferentes.

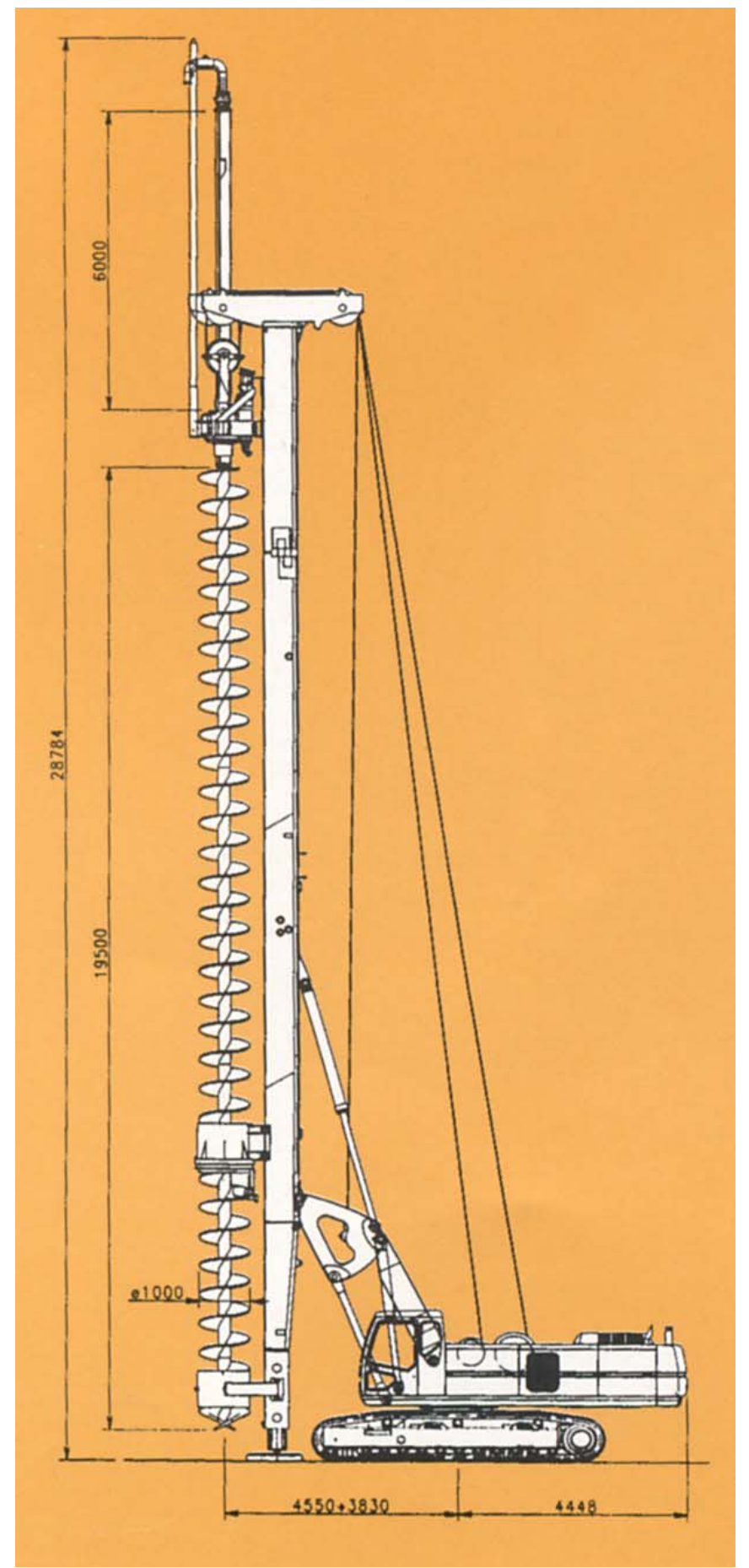

Figura 2.41 - R 622 - Dimensões principais montagem para estacas hélice contínua. 


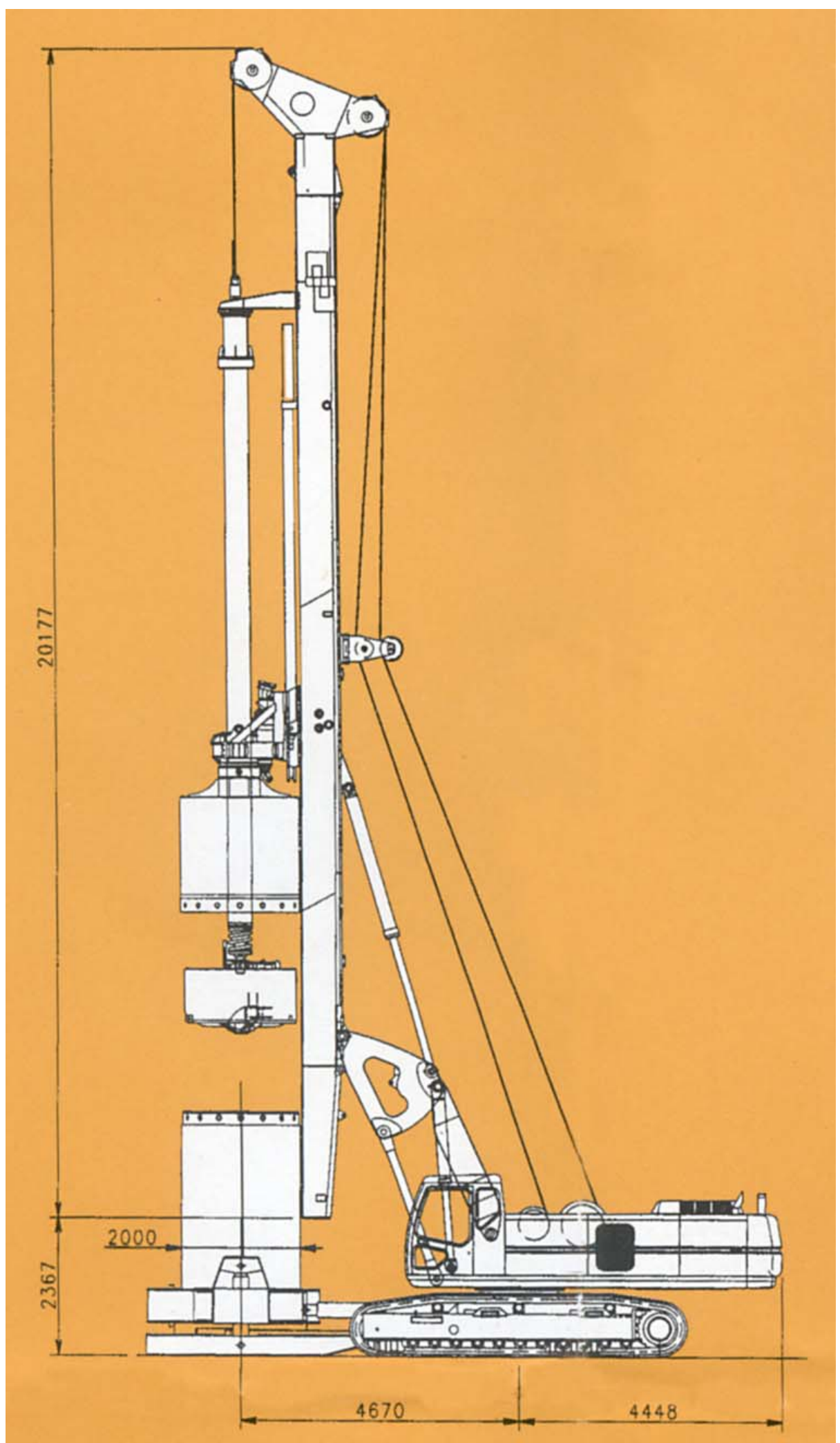

Figura 2.42 - Dimensões principais. Montagem para estacas escavadas de grande diâmetro. 


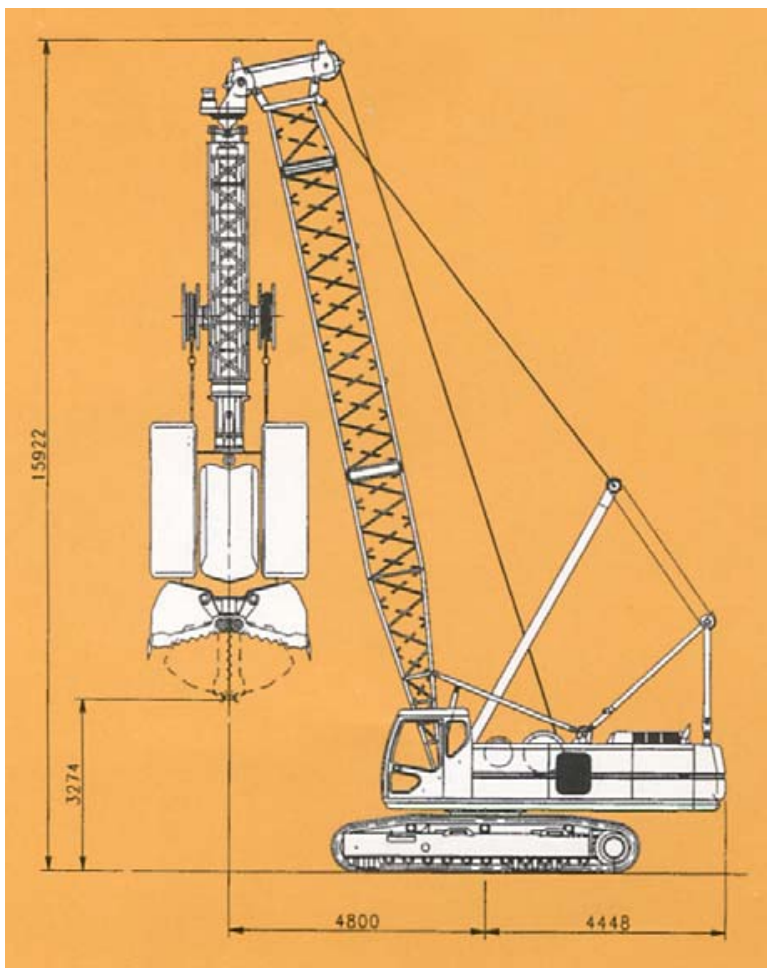

Figura 2.43 - R 622 - Montagem para execução de paredes diafragma.

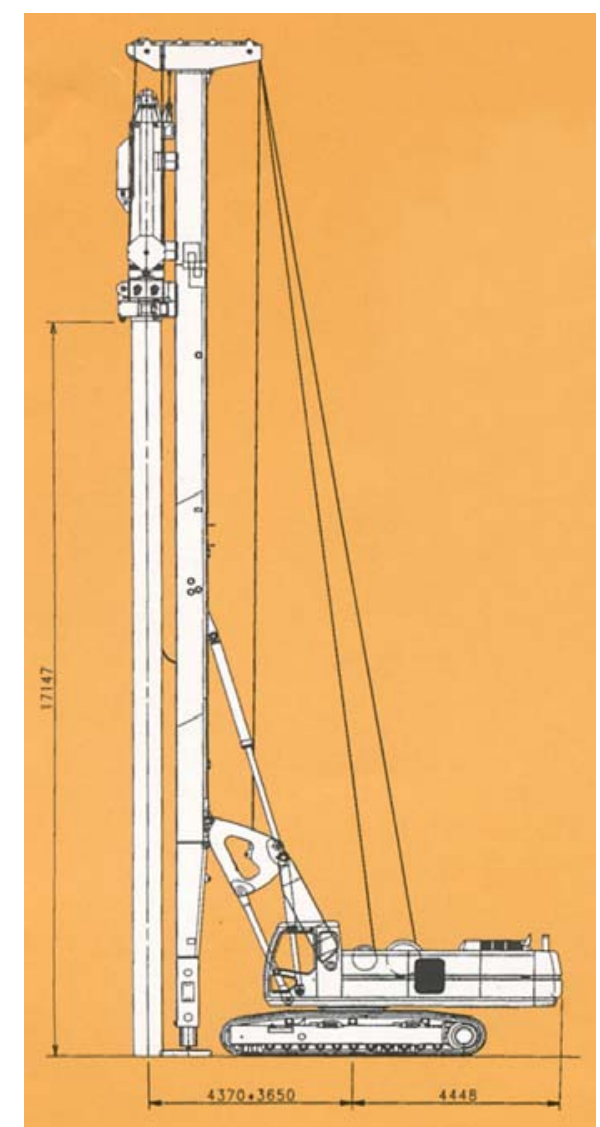

Figura 2.44 - R 622 - Montagem para estacas tubadas e concretadas in loco. 
A Tabela 2.3 apresenta as especificações técnicas da perfuratriz R-622.

Tabela 2.3 R-622 DADOS TÉCNICOS

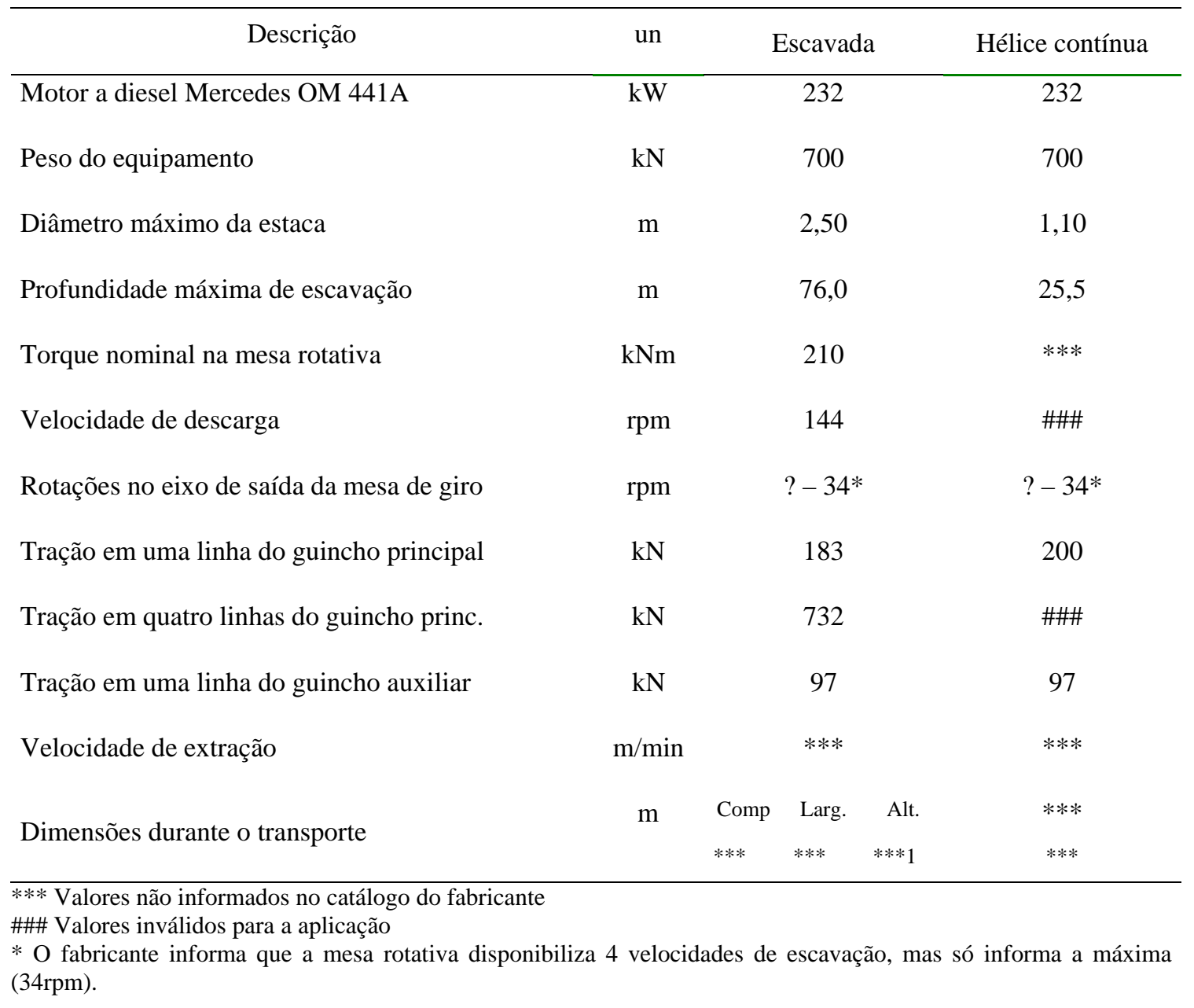

\subsubsection{EQUIPAMENTOS CMV}

A empresa CMV é italiana. Em seu país de origem, o grupo é composto por três empresas; a CMV S.P.A Geomeccanica s.r.l, a CMV - PUNTEL s.r.l e a CMV - NBC. No entanto, em vários países, ela fabrica equipamentos para fundações, em parceria (joint-venture) com outras empresas do ramo. No Brasil, a parceria foi feita com a empresa CLÓ ZIRONI, nos Estados Unidos e Canadá é representada pela CMV GROUP USA, e em Singapura pela CMV FAR EAST PTE LTDA.

A empresa tem aproximadamente 33 anos, e sua filosofia é projetar e fabricar equipamentos práticos, versáteis, simples e robustos (CMV, 2000).

Basicamente, os equipamentos fabricados pela empresa são montados sobre esteiras.

Para escavação de estacas e tubulões, as barras telescópicas (Kelly bars), podem ser fornecidas com sistema fixação por atrito ou com sistema de travamento. No sistema de 
friç̧ão, o empuxo axial máximo que se consegue durante a penetração da ferramenta de escavação é limitado pelo atrito entre os elementos que compõem o sistema de hastes telescópicas. Já no sistema interconectado, o empuxo axial (pull-down) é chamado de efetivo, ou seja, não depende do atrito entre as partes mas somente do acionador hidráulico responsável pelo esforço. Esse sistema é comum , para praticamente todos os fabricantes de equipamentos para fundações.

As características genéricas tais como: sistema de avanço e giro da torre, larguras variáveis da esteira entre outras, são muito semelhantes àquelas já descritas para os equipamentos SOILMEC. Apresentam-se a seguir, fotos dos equipamentos e desenhos contendo as dimensões principais dos mesmos. A Tabela 2.4 fornece os dados técnicos das principais máquinas produzidas pela empresa. As fotos, desenhos e especificações técnicas foram obtidos nos catálogos do fabricante (CMV, 2000).

\subsection{EQUIPAMENTO TH 10/25}

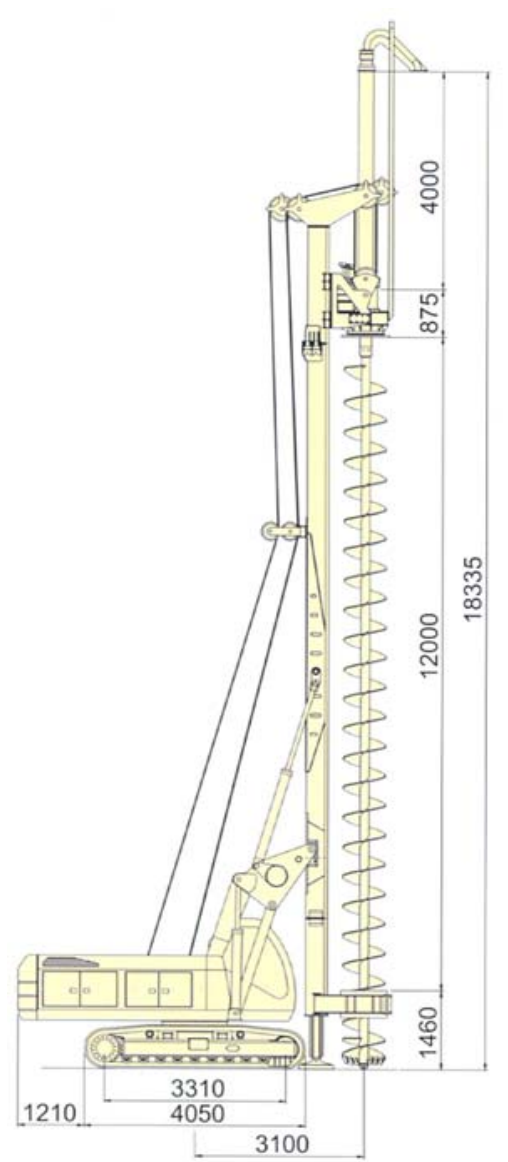

Figura 2.45 TH 10/25 - Dimensões principais (CMV, 2000).

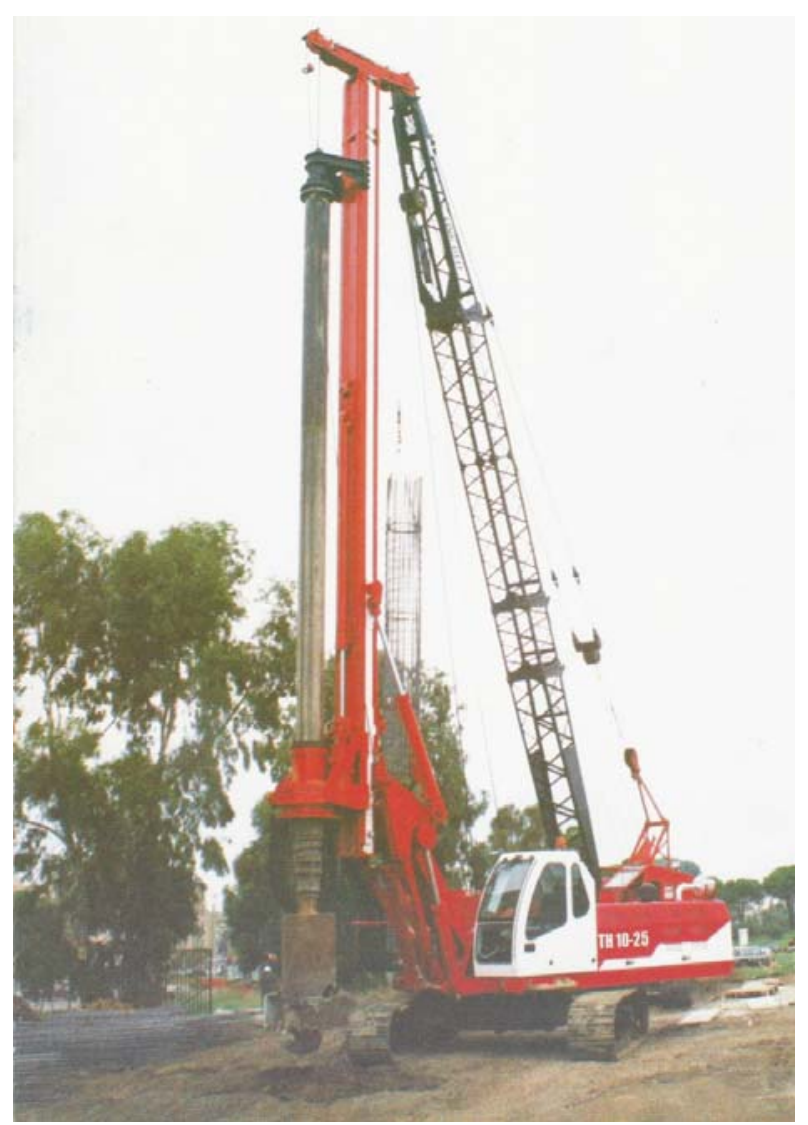

Figura 2.46 - TH 10/25 - Vista de escavação com utilização de balde (CMV, 2000). 
2.3.6.2.2. EQUIPAMENTO TH 10/30

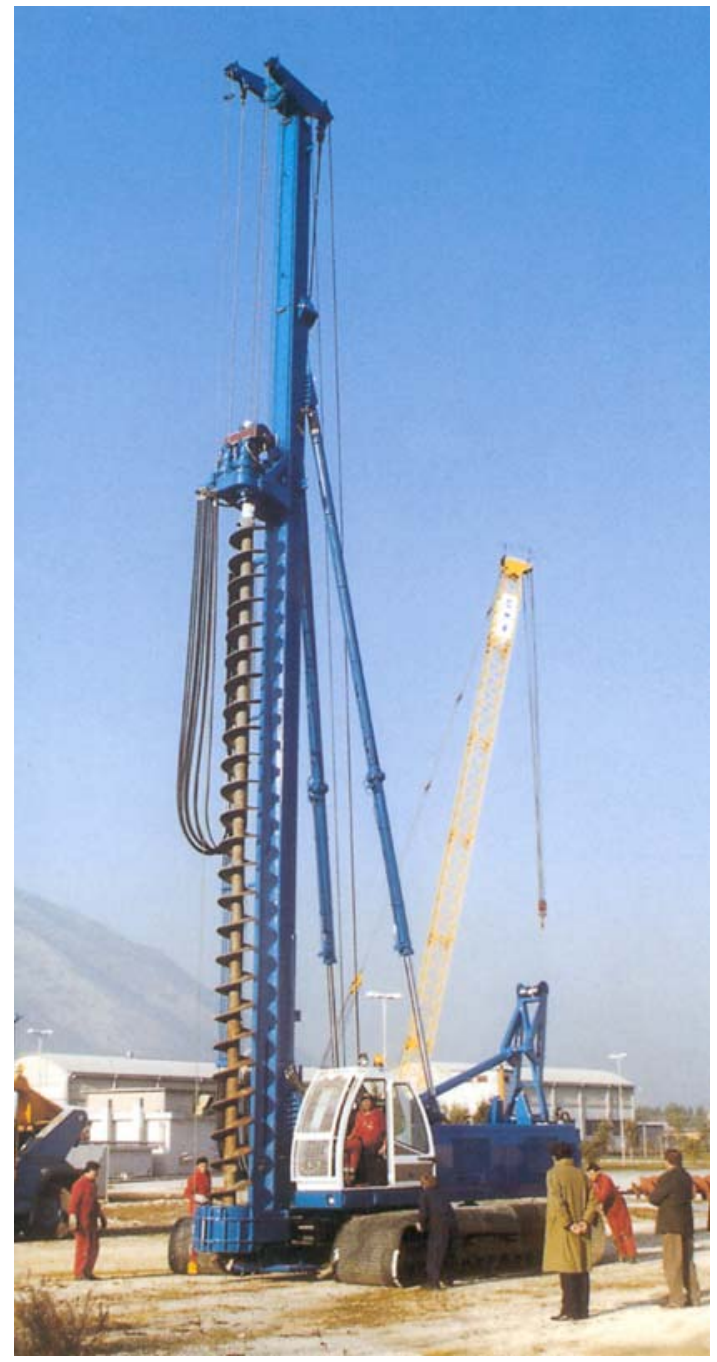

Figura 2.47 TH 10/30 - Vista executando estaca hélice (CMV, 2000).

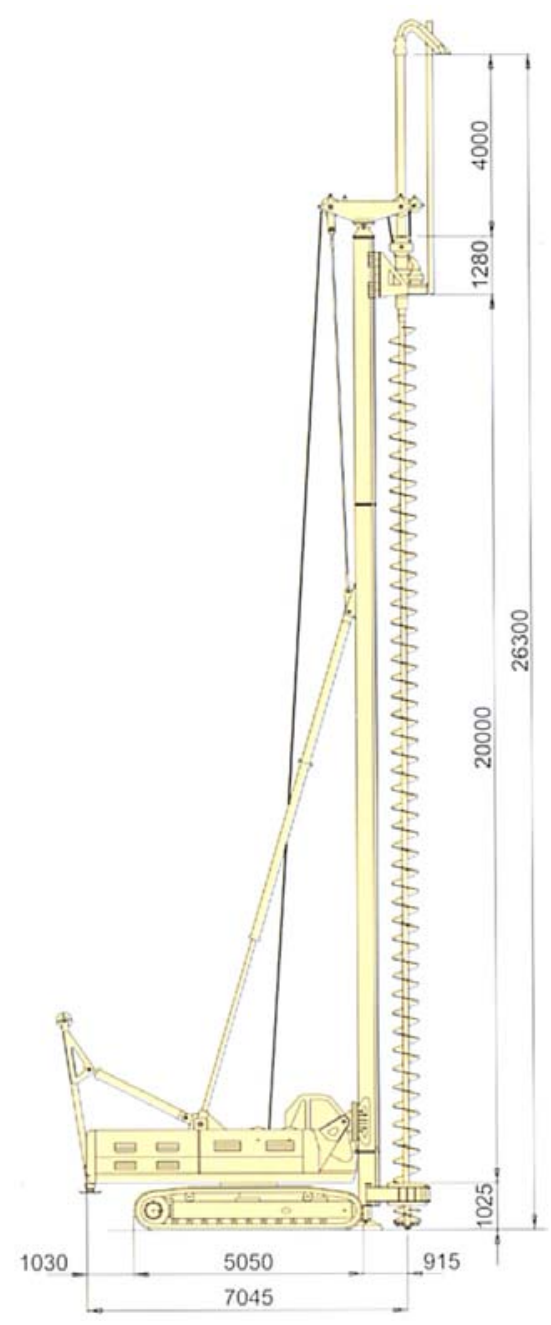

Figura 2.48 - Dimensões principais (CMV, 2000). 
2.3.6.2.3. EQUIPAMENTO TH 14/35

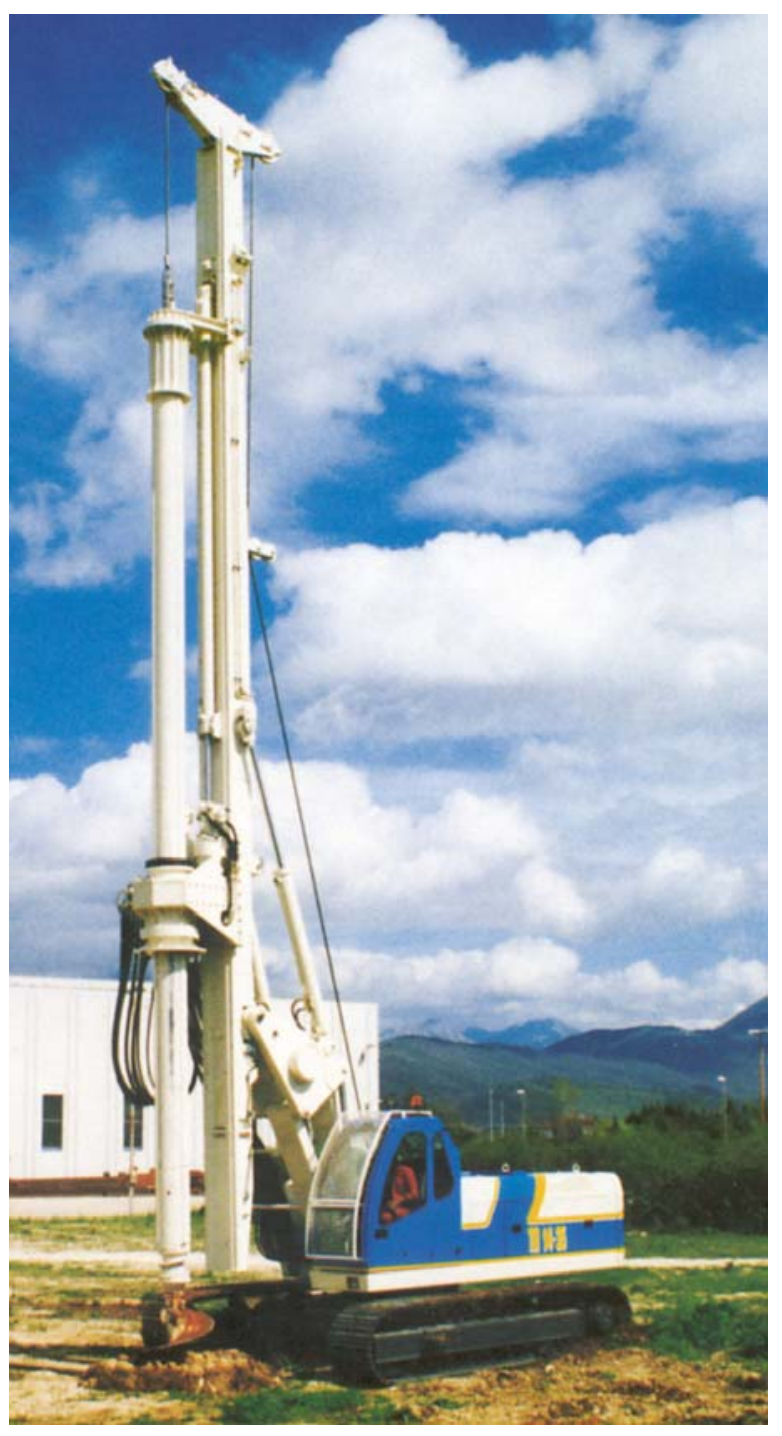

Figura 2.49 - Vista do equipamento (CMV, 2000).

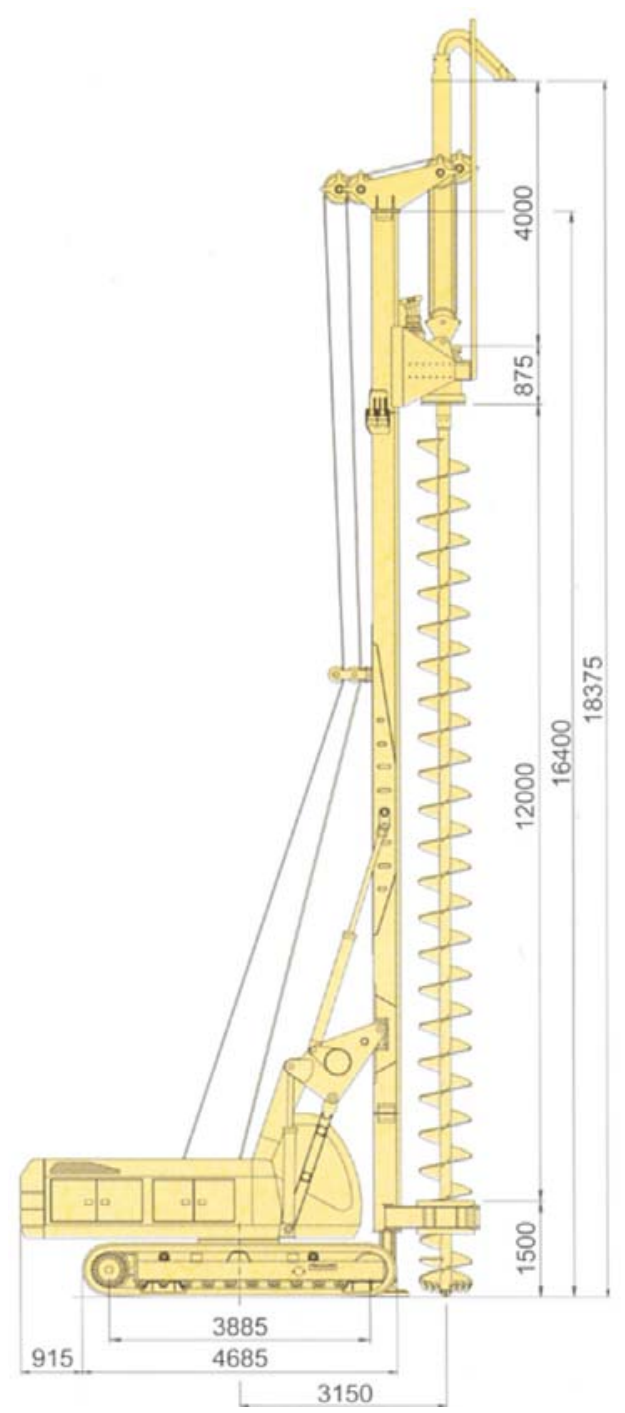

Figura 2.50 - Dimensões principais (CMV, 2000). 


\subsection{EQUIPAMENTO TH 16/50}

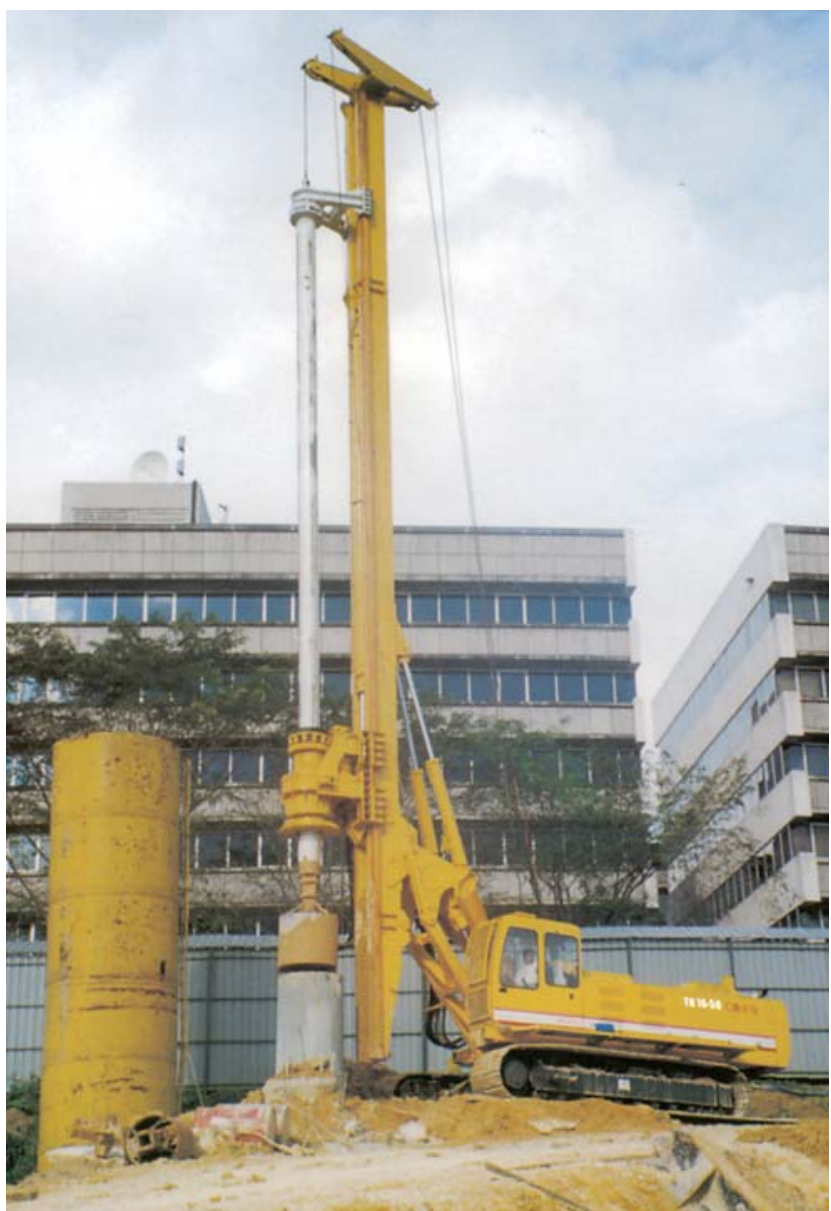

Figura 2.51 TH 16/50 - Vista do equipamento (CMV, 2000).

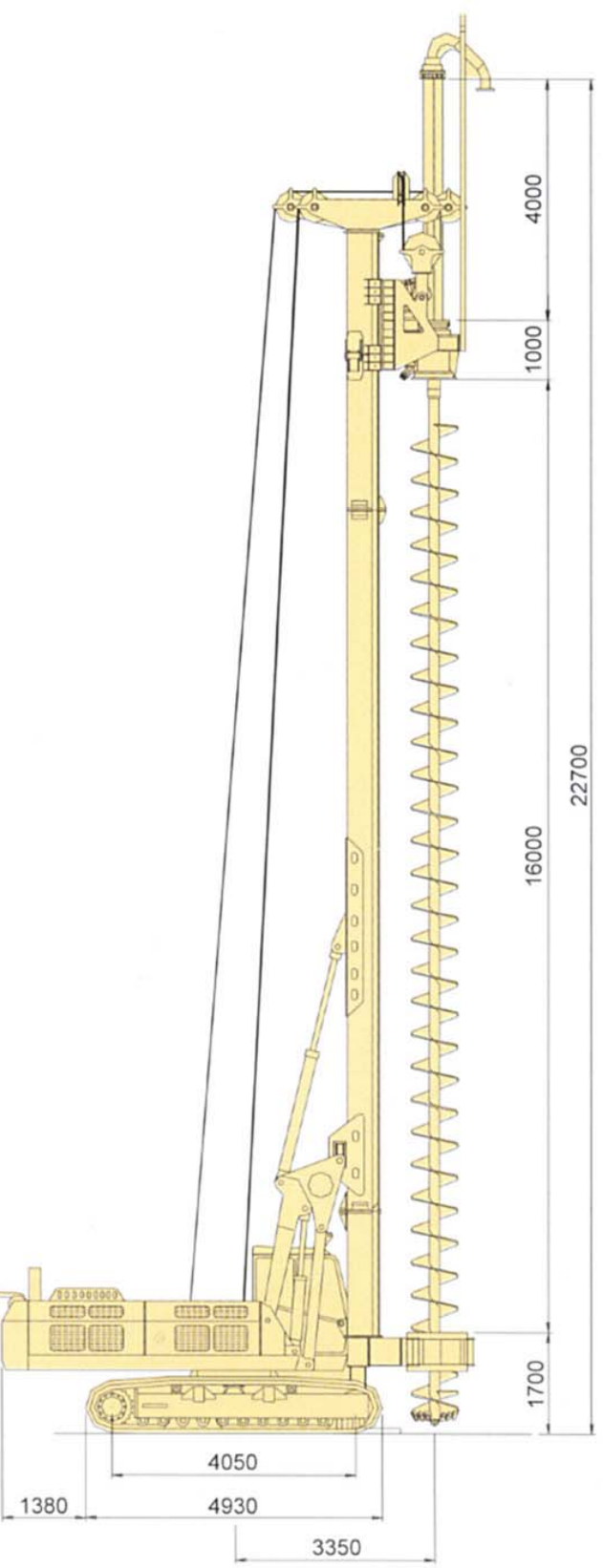

Figura2.52 - TH 16/50-Dimensões principais (CMV, 2000). 


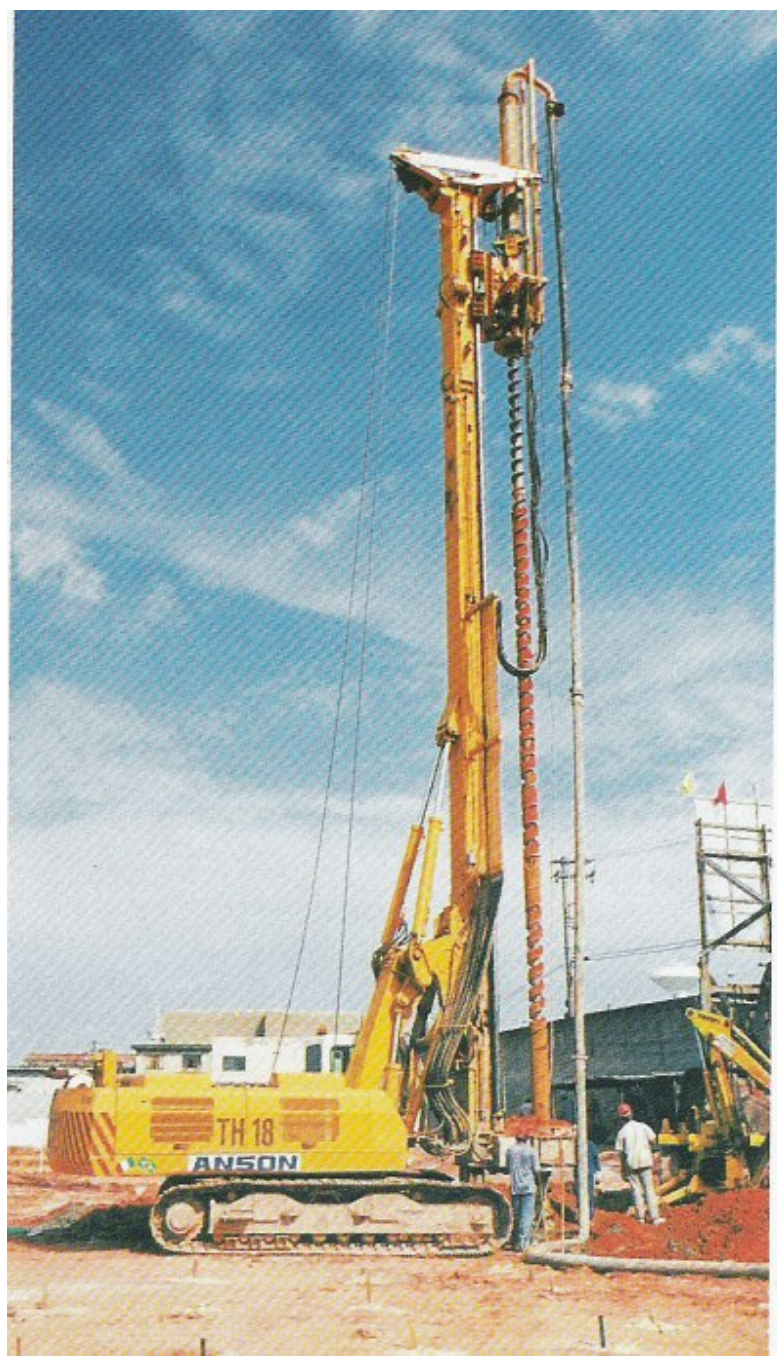

Figura 2.53 - TH 18/60 - Vista do equipamento (CMV, 2000).

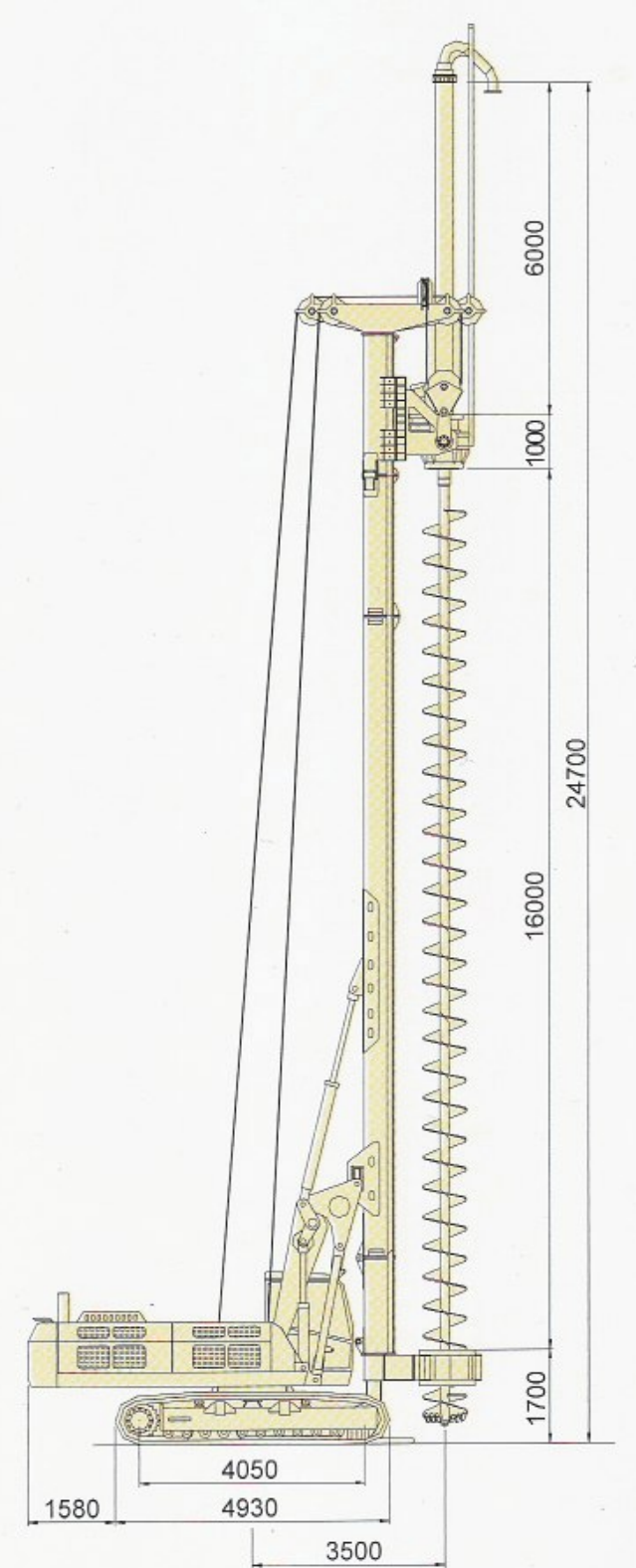

Figura 2.54 - TH 1860 - Dimensões principais (CMV, 2000). 


\subsection{EQUIPAMENTO TH 22/75}

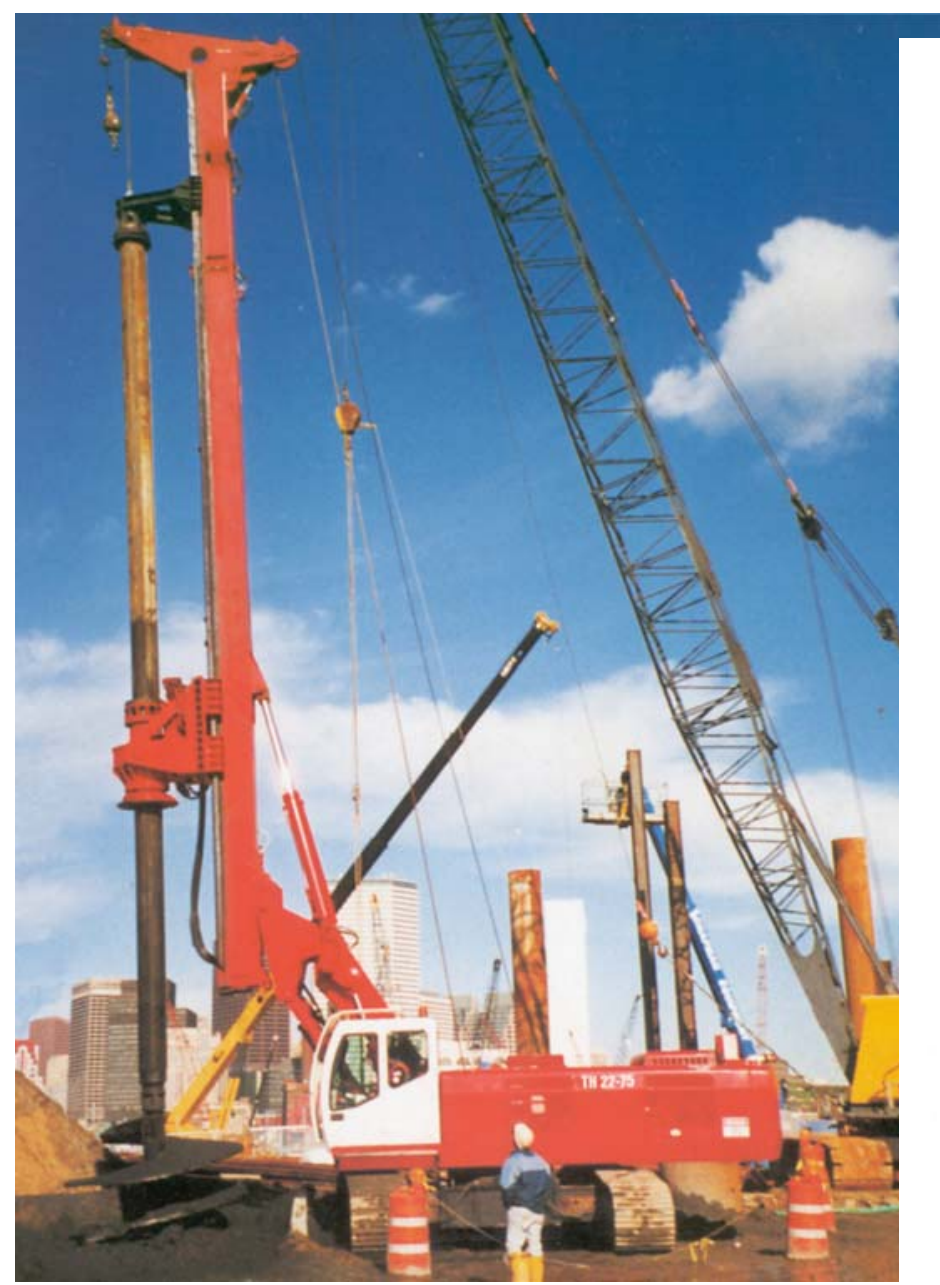

Figura 2.55 - TH 22/75 - Vista do equipamento (CMV, 2000).

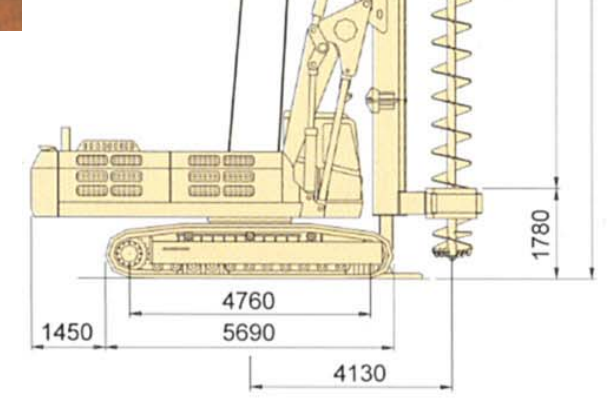

Figura 2.56 - TH 22/75 - Dimensões principais (CMV, 2000).

As empresas procuram utilizar o máximo possível de componentes padronizados para equipar os diversos modelos. Dessa forma, há redução de custos, a produtividade aumenta, o fornecimento de peças de reposição é facilitado e os preços de venda ficam mais baixos.

Visto que as características principais de um equipamento de hélice contínua, não sofrem diferenças significativas quando da utilização na execução de outro tipo de 
fundação, as figuras contendo as dimensões principais dos equipamentos da empresa CMV, foram apresentadas somente para a aplicação em hélice contínua. Assim, faz-se da mesma forma com as tabelas que se seguem para apresentação dos dados técnicos desses equipamentos.

Tabela 2.4 - DADOS TÉCNICOS DOS EQUIPAMENTOS CMV- Série TH

\begin{tabular}{llllllll}
\hline \multicolumn{1}{c}{ Descrição } & un & $10 / 25$ & $10 / 30$ & $14 / 35$ & $16 / 50$ & $18 / 60$ & $22 / 75$ \\
\hline Motor a diesel & $\mathrm{kW}$ & 115 & 160 & 170 & 224 & 224 & 300 \\
Peso do equipamento & $\mathrm{kN}$ & 280 & 400 & 325 & 500 & 600 & 750 \\
Diâmetro máximo da estaca & $\mathrm{m}$ & 0,60 & 0,80 & 1,00 & 0,80 & 1,00 & 1,00 \\
Profundidade máxima de escavação & $\mathrm{m}$ & 16,00 & 24,00 & 16,00 & 20,00 & 22,00 & 25,00 \\
Torque nominal na mesa rotativa & $\mathrm{kNm}$ & 100,0 & 100,0 & 140,0 & 160,0 & 180,0 & 220,0 \\
Rotações na saída da mesa rotativa & $\mathrm{Rpm}$ & $8-22$ & 25 & $9-22$ & $9-22$ & $8-22$ & $9-22$ \\
Tração no guincho principal (uma linha) & $\mathrm{kN}$ & 100,0 & 100,0 & 140,0 & 160,0 & 180,0 & 180,0 \\
Tração na hélice durante a extração & $\mathrm{kN}$ & 400,0 & 400,0 & 560,0 & 520,0 & 520,0 & 640,0 \\
Velocidade no guincho (linha simples) & $\mathrm{m} / \mathrm{s}$ & $* * *$ & $* * *$ & $* * *$ & $* * *$ & $* * *$ & $* * *$ \\
Velocidade máxima de extração da hélice & $\mathrm{m} / \mathrm{s}$ & $* * *$ & $* * *$ & $* * *$ & $* * *$ & $* * *$ & $* * *$ \\
Tração no guincho auxiliar & $\mathrm{kN}$ & 50,0 & 50,0 & 55,0 & 80,0 & 80,0 & 100,0 \\
Velocidade do guincho auxiliar & $\mathrm{m} / \mathrm{s}$ & $* * *$ & $* * *$ & $* * *$ & $* * *$ & $* * *$ & $* * *$ \\
\hline
\end{tabular}

*** Valores não informados pelo fabricante

\subsubsection{EQUIPAMENTOS CLÓ ZIRONI}

A Cló Zironi é uma empresa nacional, fundada em 1976. Desenvolve e fabrica uma grande variedade de equipamentos para geotecnia e fundações. Sua sede localiza-se na cidade de Belo Horizonte - MG.

Os equipamentos para estacas hélice contínua fabricados pela empresa, são mostrados a seguir.

\subsection{EQUIPAMENTO CFA 60}

Utiliza uma escavadeira CAT 320 BL, como chassi básico. Foi projetada para escavar com trado contínuo de até 0,60 m de diâmetro e profundidade de até 13,5 m sem a haste de prolongamento e 18 m com a inclusão dessa haste (prolonga).

A Figura 2.57 mostra uma vista geral do equipamento 


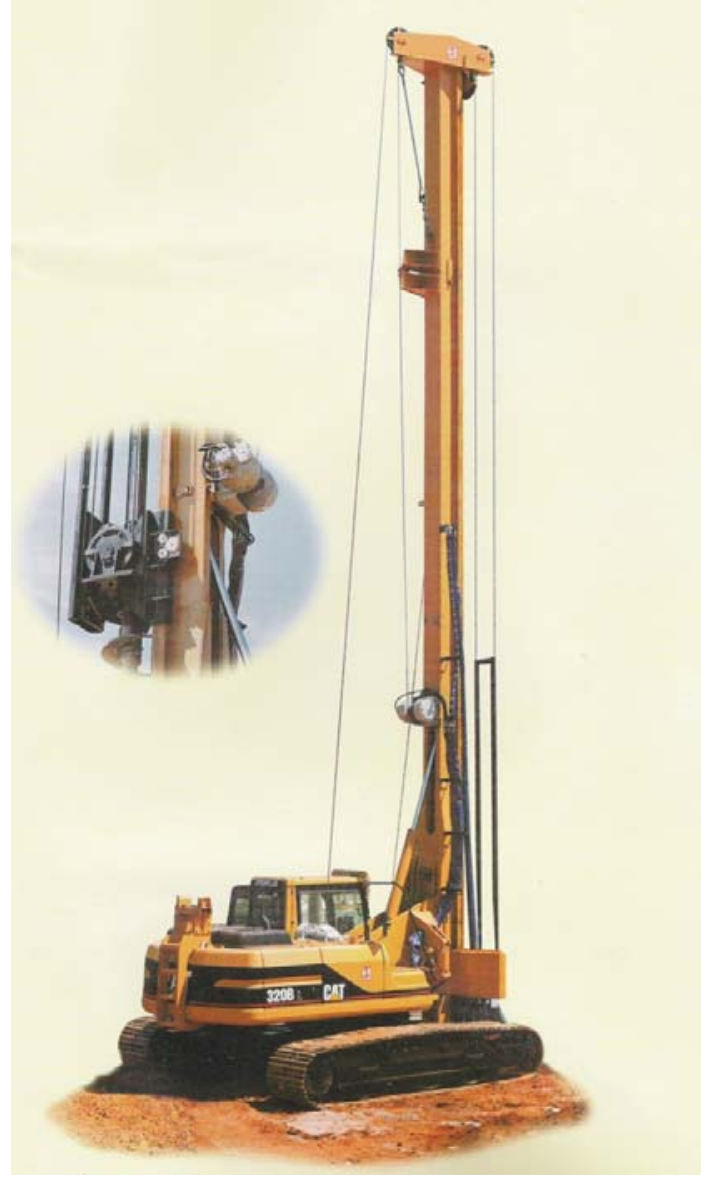

Figura 2.57 - Equipamento CFA 60 (Cló Zironi, 200-?).

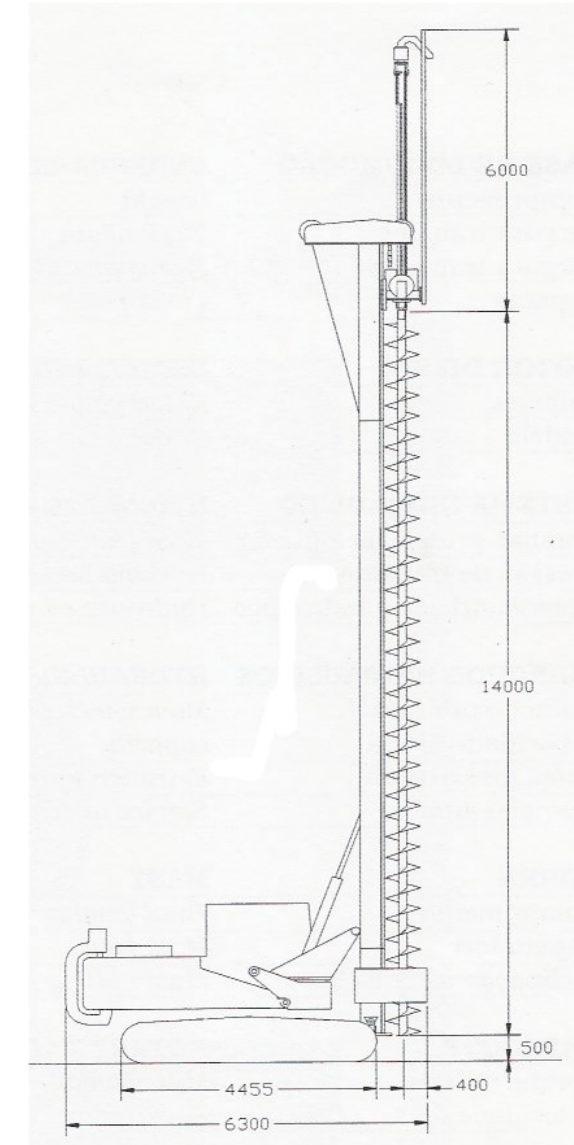

Figura 2.58 - CFA 60 - Dimensões principais (Cló Zironi, 200-?).

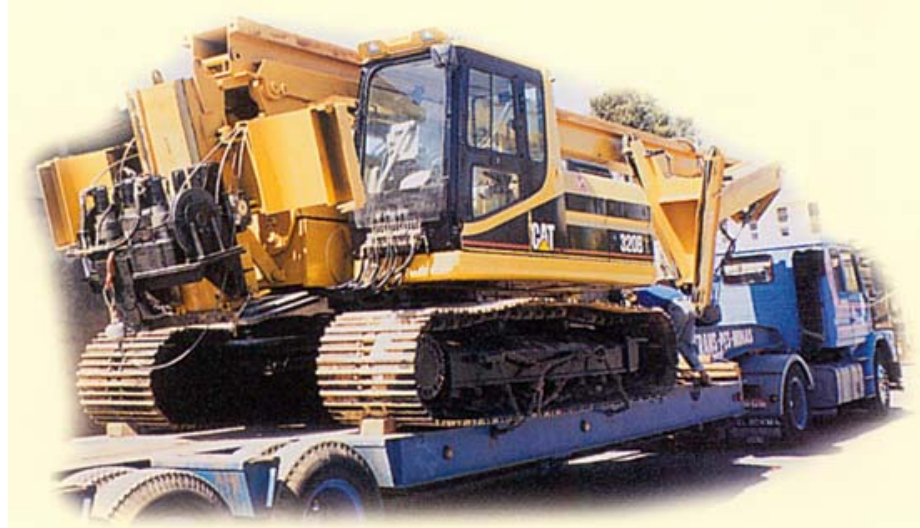

Figura 2.59 - CFA 60 - Posição de transporte (Cló Zironi, 200-?).

Na Figura 2.59 vê-se que a torre é dotada de um segmento articulado, localizado na parte superior. Na posição de transporte, esse segmento é rotacionado de $180^{\circ}$, resultando numa diminuição do comprimento da máquina. Esse recurso é interessante, já que possibilita a utilização de um veículo (carreta) de menor comprimento. 


\subsection{EQUIPAMENTO CD 30 - CFA}
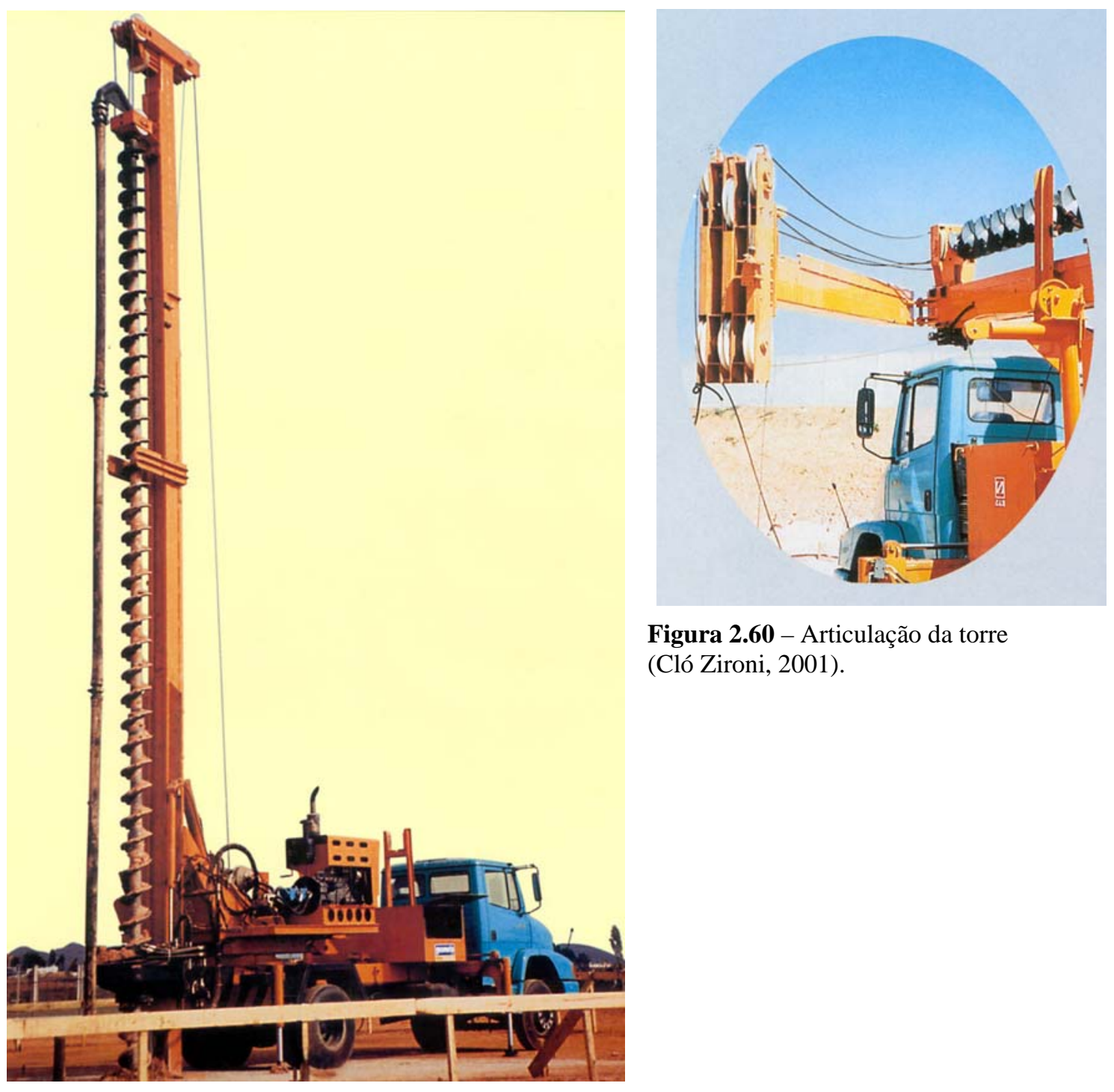

Figura 2.60 - Articulação da torre (Cló Zironi, 2001).

Figura 2.61 - Vista geral - CD 30 - CFA (Cló Zironi, 2001).

Esse equipamento utiliza o cabeçote rotativo na parte inferior da torre, batizado de sistema "bottom drive CFA". Segundo o fabricante, esse sistema é patenteado e tem as seguintes vantagens em relação ao sistema tradicional:

- Abaixa o centro de gravidade do equipamento, melhorando sua estabilidade.

- Pode tornar possível o dimensionamento de estruturas mais leves já que o torque do cabeçote rotativo é transmitido apenas na parte inferior da torre.

Embora o sistema seja muito interessante, cabe ressaltar que ele apresenta a seguinte desvantagem em relação aos equipamentos convencionais: 
- Existe limitação do diâmetro máximo de escavação, já que a hélice passa pelo centro do cabeçote rotativo. Mesmo aumentando-se o torque, a partir de um determinado diâmetro da hélice, as dimensões da mesa rotativa tornam o sistema inviável.

Todo o conjunto pode ser equipado com um sistema eletrônico de monitoramento.

A Figura 2.62 mostra uma vista do sistema de transmissão de torque, com o trado passando por dentro da mesa rotativa.

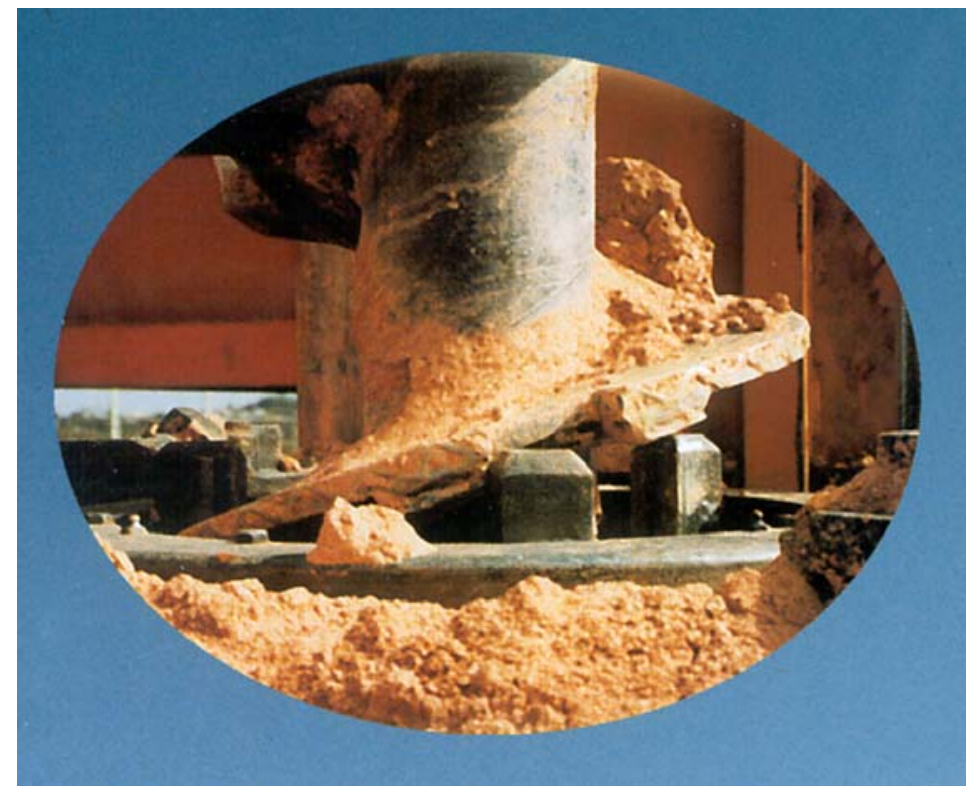

Figura 2.62 - Vista do mecanismo transmissor de torque no sistema "bottom drive".

\subsection{EQUIPAMENTO CA 60}

Os modelos CA 60 e CA 80 da Cló Zironi, são instalados sobre plataforma de escavadeira modelo 320 CL, da empresa Caterpillar. Nas versões para hélice contínua é utilizado o sistema de cabeçote rotativo na parte inferior da torre "bottom drive CFA". Para os dois modelos, o empuxo axial (pull-down) é dado por um cilindro hidráulico instalado sobre a mesa rotativa. No modelo CA 80 a esteira pode ser estendida lateralmente por um sistema hidráulico, resultando em maior estabilidade do conjunto. O sistema de monitoramento eletrônico é opcional.

As Figuras 2.63 e 2.64 mostram algumas vistas do equipamento. 

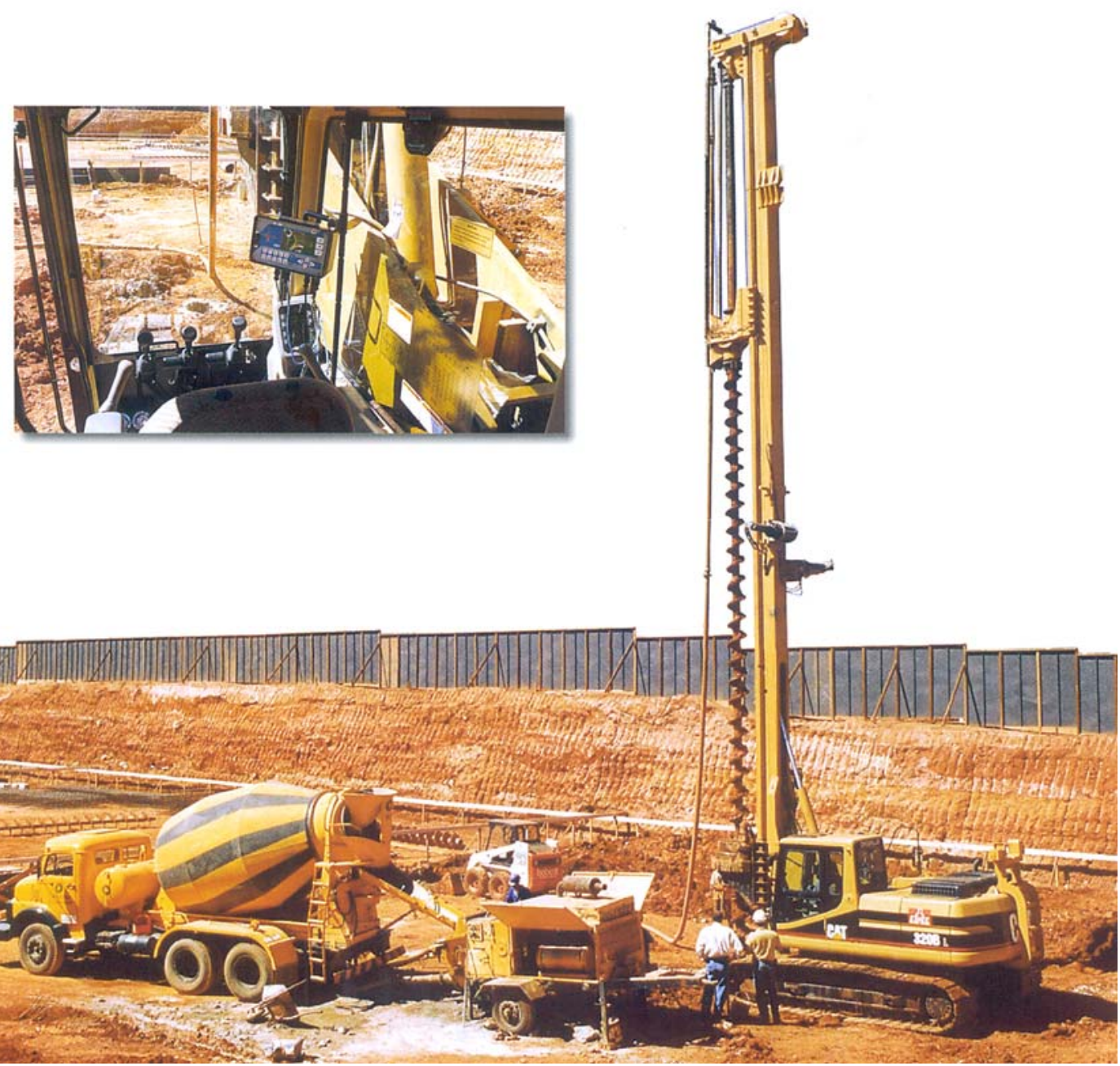

Figura 2.63 - Vista do equipamento CA 60, caminhão betoneira e bomba de concreto (Cló Zironi, 2001).

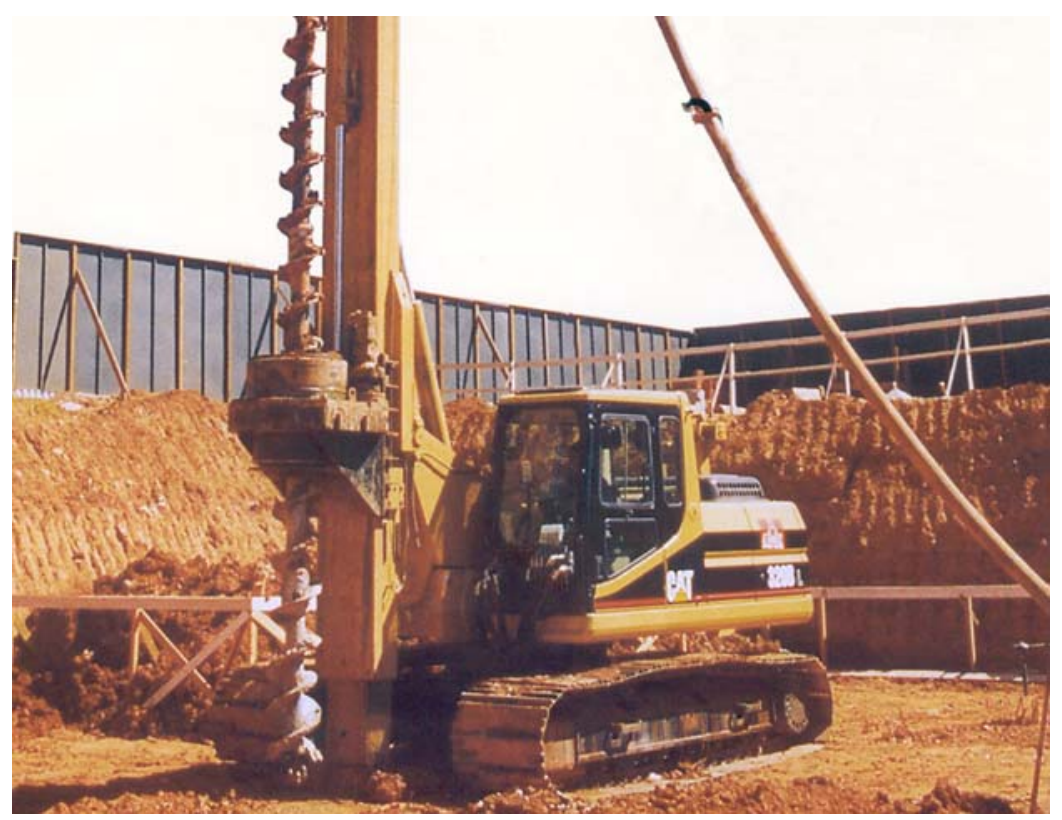

Figura 2.64 - Equipamento CA 60 - Vista mesa rotativa e esteira (Cló Zironi, 2001). 
Tabela 2.5 - DADOS TÉCNICOS DOS EQUIPAMENTOS CLÓ ZIRONI

\begin{tabular}{lcc|c|c|c|}
\hline \multicolumn{1}{c}{ Descrição } & un & CFA 60 & CD 30-CFA & CA 60 & CA 80 \\
\hline Motor a diesel & $\mathrm{kW}$ & 100,0 & 82,0 & 101,0 & $* * *$ \\
Peso do equipamento & $\mathrm{kN}$ & 280,0 & 110,0 & 280,0 & 300,0 \\
Diâmetro máximo da estaca & $\mathrm{m}$ & 0,60 & 0,50 & 0,60 & 0,80 \\
Profundidade máxima de escavação & $\mathrm{m}$ & 18,0 & 13,0 & 20,0 & 20,0 \\
Torque nominal na mesa rotativa & $\mathrm{kNm}$ & 80,0 & 45,0 & 100,0 & 120,0 \\
Rotações na saída da mesa rotativa & $\mathrm{rpm}$ & $10-25$ & $15-30$ & $* * *$ & $* * *$ \\
Tração no guincho principal (uma linha) & $\mathrm{kN}$ & 90,0 & 50,0 & $* * *$ & $* * *$ \\
Tração na hélice durante a extração & $\mathrm{kN}$ & 360,0 & 200,0 & $* * *$ & $* * *$ \\
Velocidade no guincho (linha simples) & $\mathrm{m} / \mathrm{s}$ & $* * *$ & $* * *$ & $* * *$ & $* * *$ \\
Velocidade máxima de extração da hélice & $\mathrm{m} / \mathrm{s}$ & $* * *$ & $* * *$ & $* * *$ & $* * *$ \\
Tração no guincho auxiliar & $\mathrm{kN}$ & 50,0 & 50,0 & 50,0 & $* * *$ \\
Velocidade do guincho auxiliar & $\mathrm{m} / \mathrm{s}$ & $* * *$ & $* * *$ & $* * *$ & $* * *$
\end{tabular}

*** Valores não informados pelo fabricante

\subsubsection{EQUIPAMENTOS MAIT}

É uma empresa com mais de 50 anos de atividade. Atua nas áreas de equipamentos para fundações, geotecnia e exploração de água no subsolo. A seguir apresentam-se alguns dos equipamentos fabricados pela empresa.

\subsubsection{EQUIPAMENTO EB 12}

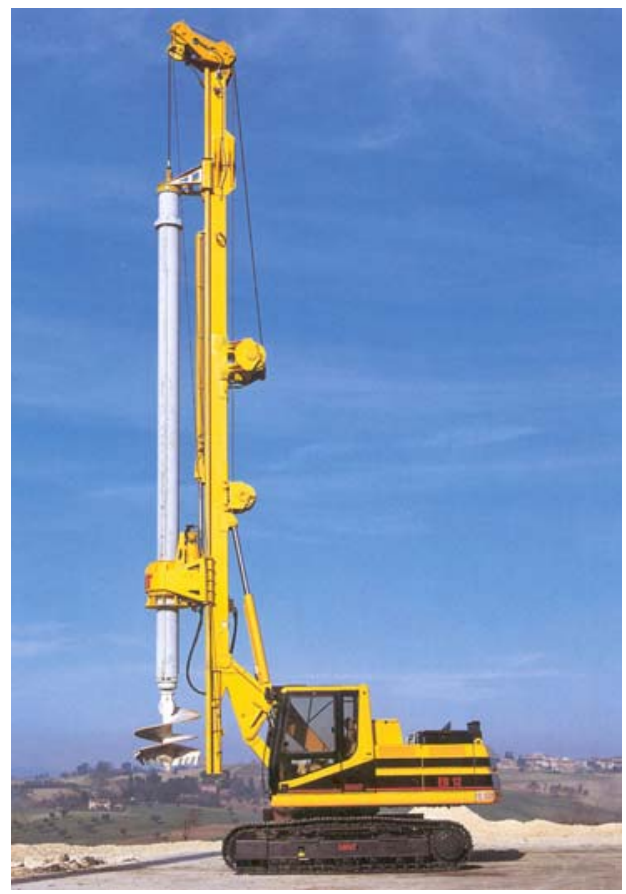

Figura 2.65 - Equipamento EB 12 (MAIT, 98).

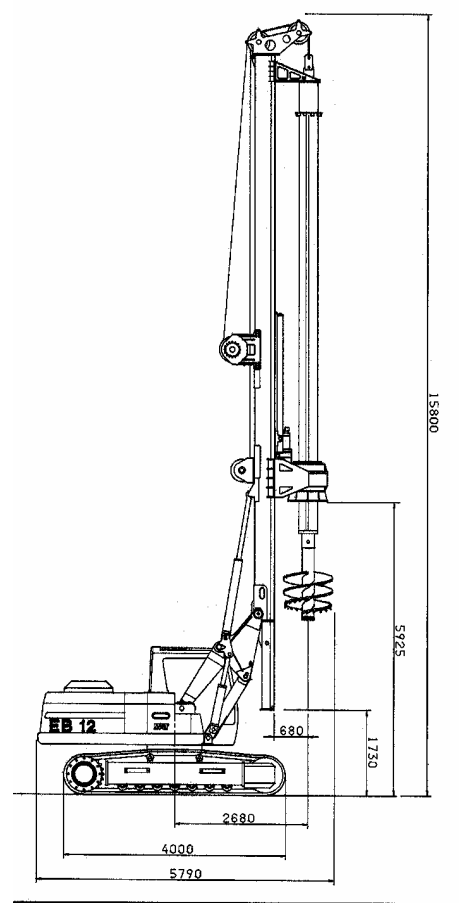

Figura 2.66 - EB 12 - Dimensões principais (MAIT, 98). 
2.3.6.4.2. EQUIPAMENTO HR 45

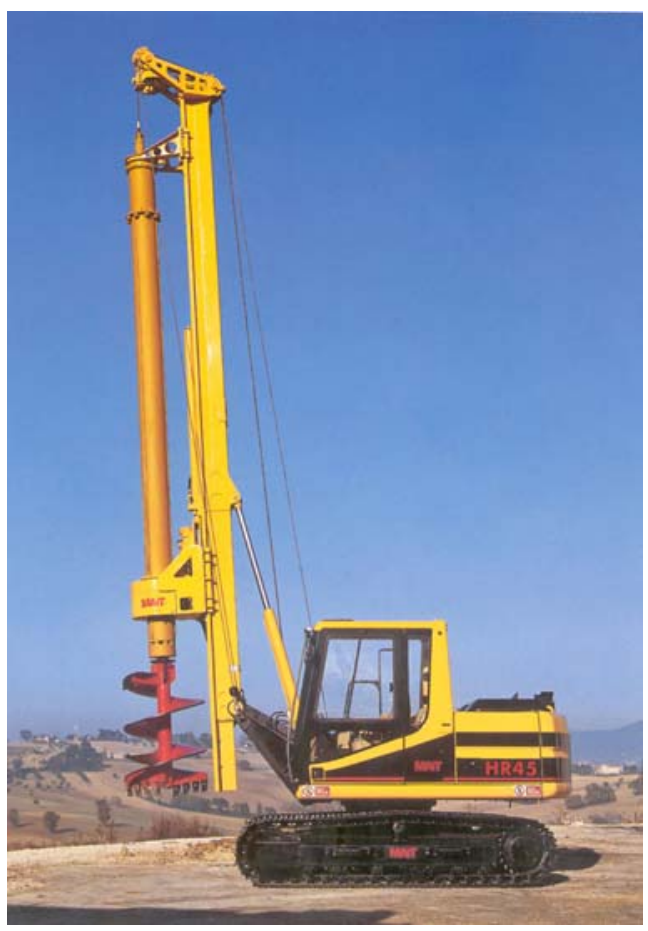

Figura 2.67 - Equipamento HR 45 (MAIT, 98).

\subsection{EQUIPAMENTO HR 110}

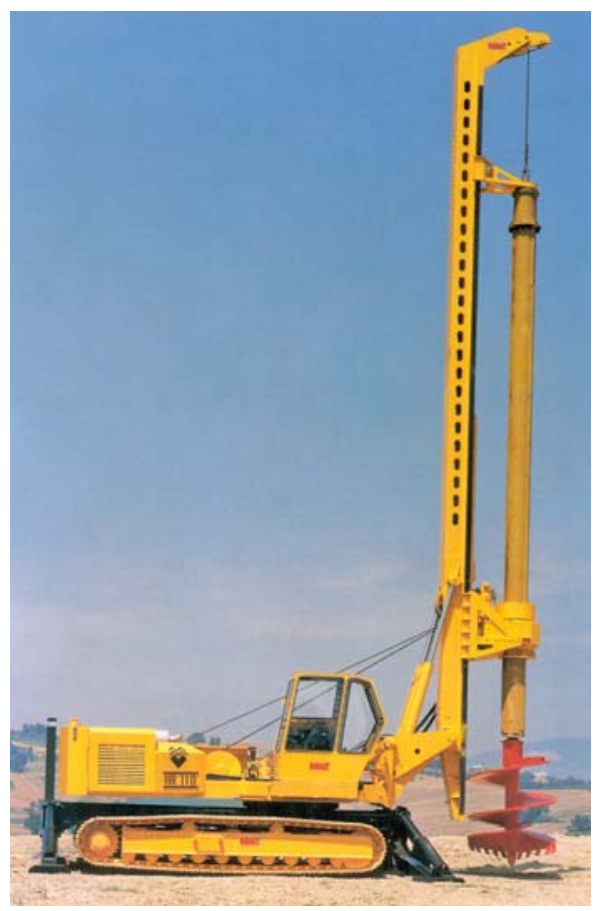

Figura 2.69 - Equipamento HR 110 (MAIT, 98).

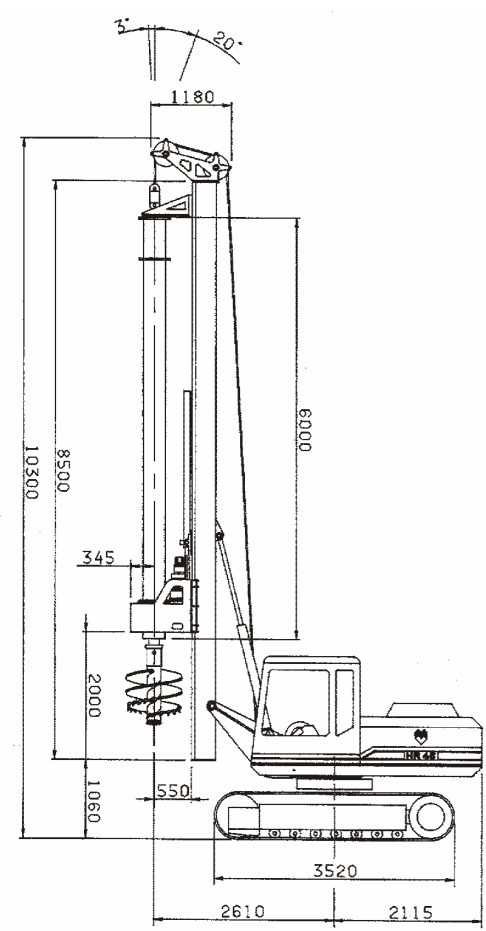

Figura 2.68 - HR 45 - Dimensões principais (MAIT, 98).

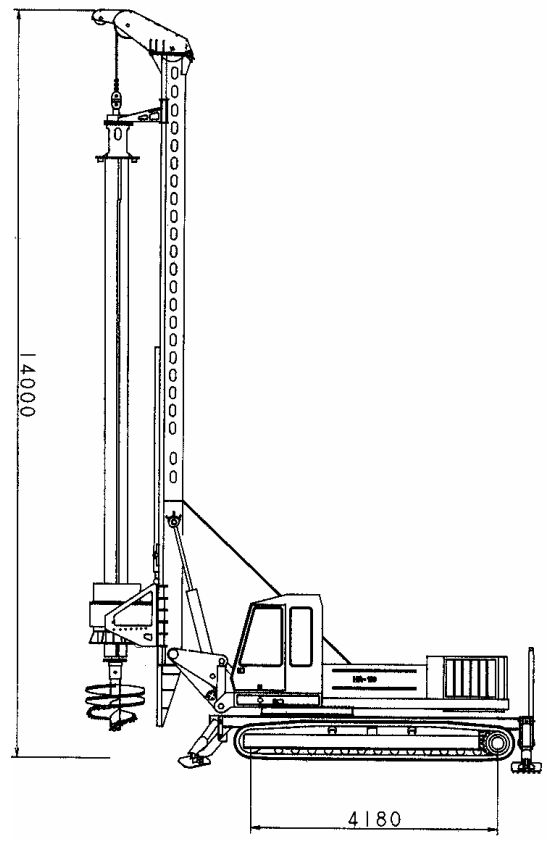

Figura 2.70 - HR 110 - Dimensões principais (MAIT, 98). 
2.3.6.4.4. EQUIPAMENTO HR 130

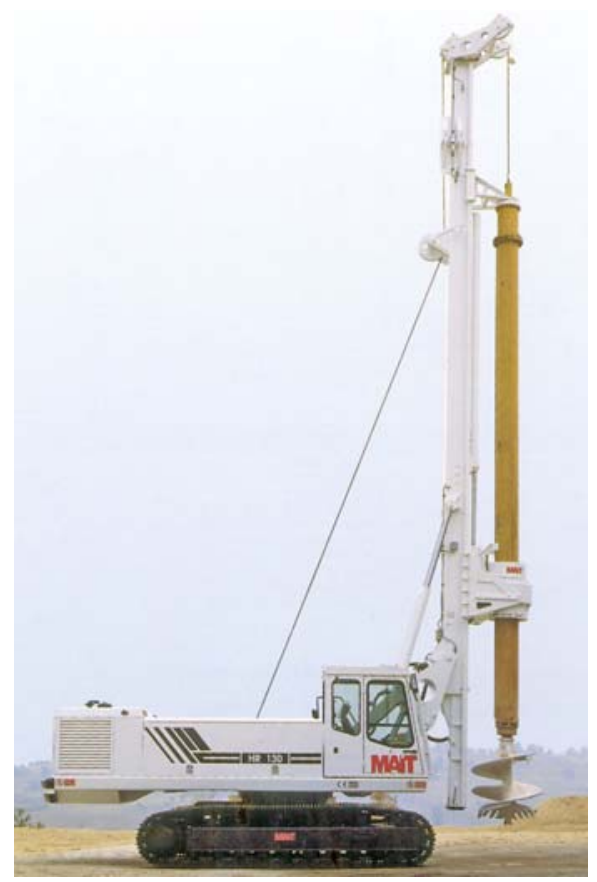

Figura 2.71 - Equipamento HR 130 (MAIT, 98).

\subsection{EQUIPAMENTO HR 160}

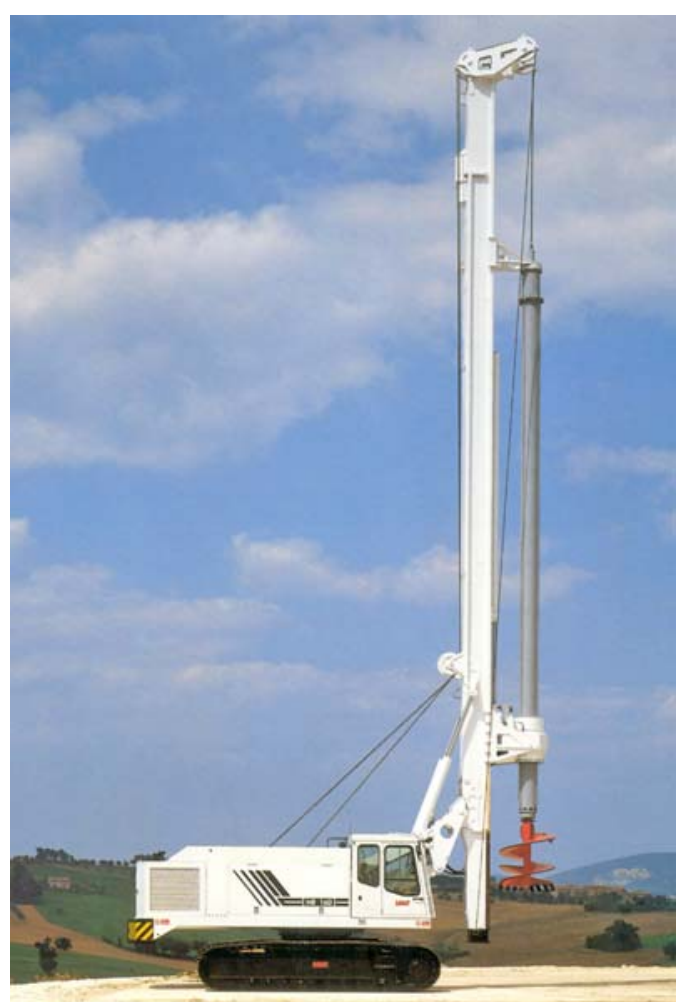

Figura 2.73 - Equipamento HR 160 (MAIT, 98).

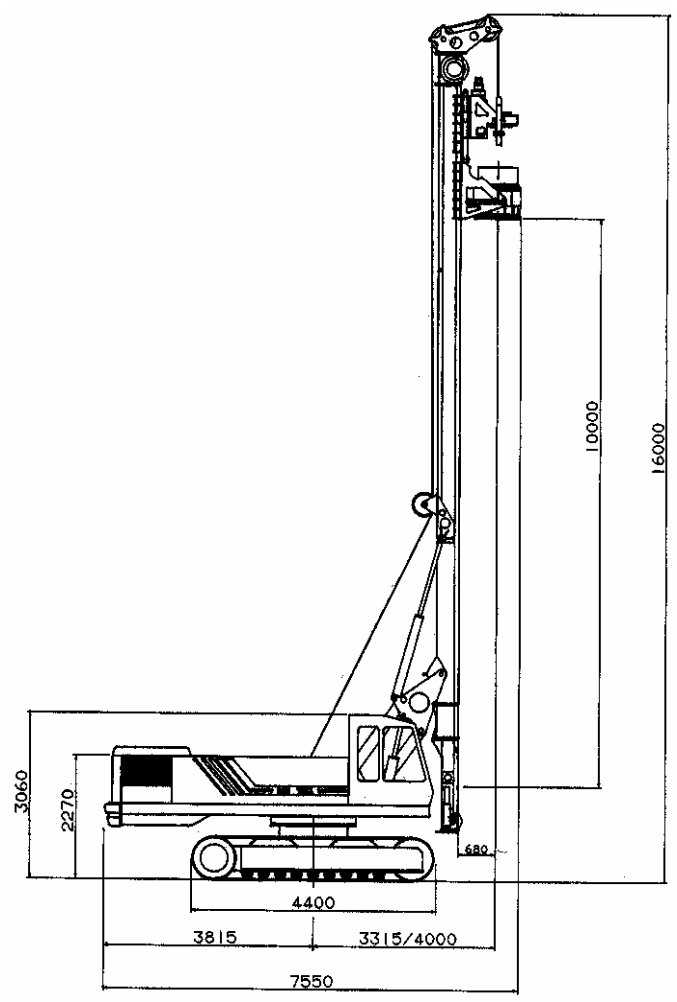

Figura 2.72 - HR 130 - Dimensões principais (MAIT, 98).

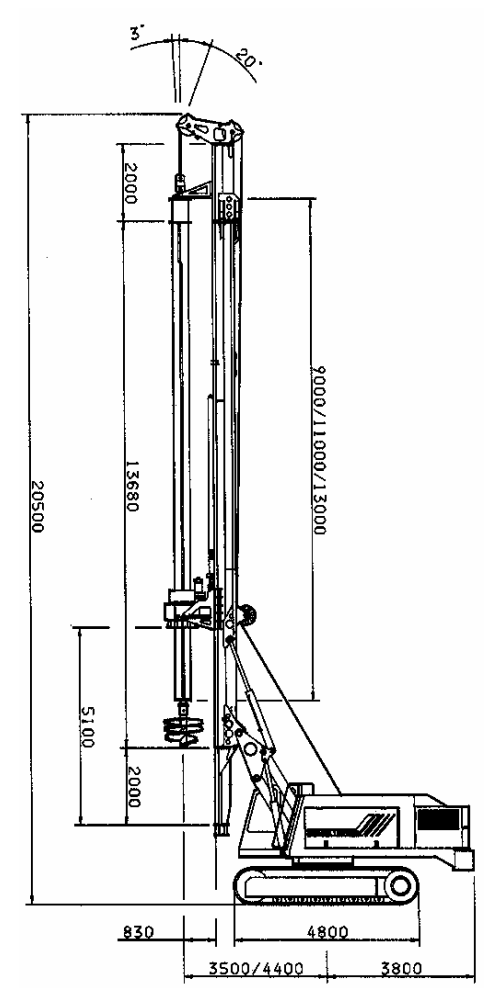

Figura 2.74 - HR 160 Dimensões principais (MAIT, 98). 
2.3.6.4.6. EQUIPAMENTO HR 200

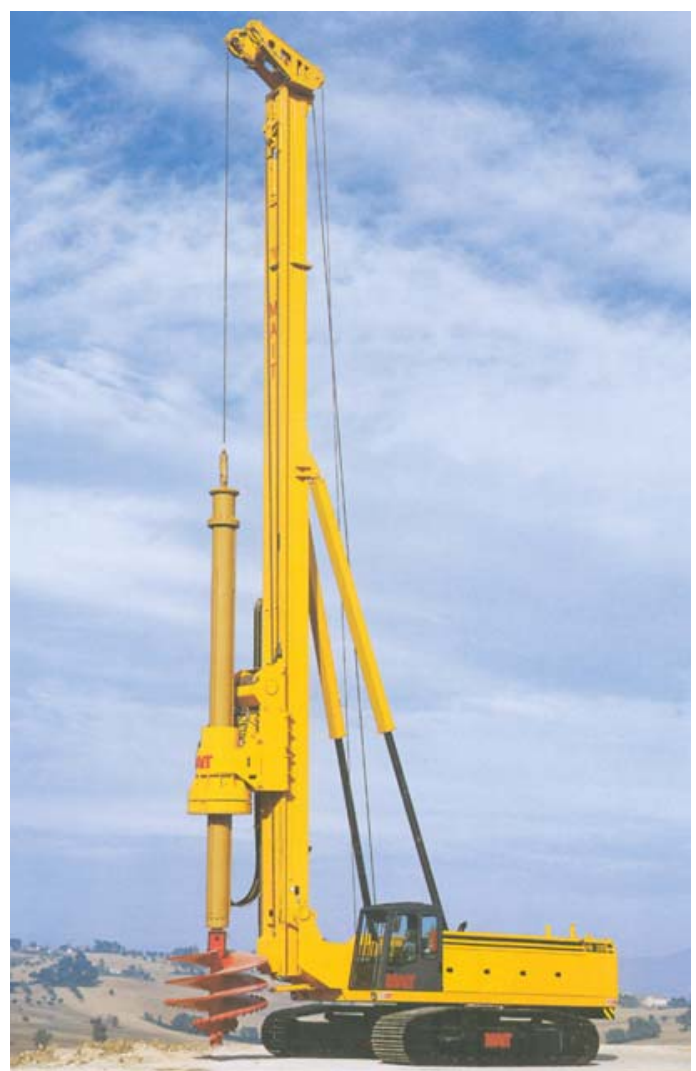

Figura 2.75 - Equipamento HR 200 (MAIT, 98).

\subsection{EQUIPAMENTO HR 240}

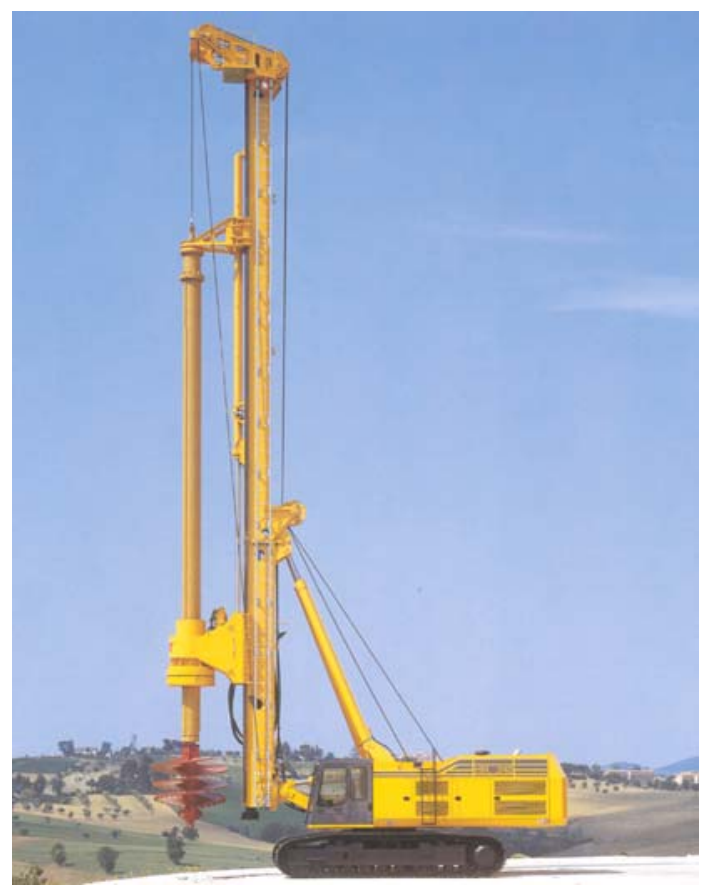

Figura 2.77 - Equipamento HR 240 (MAIT, 98).

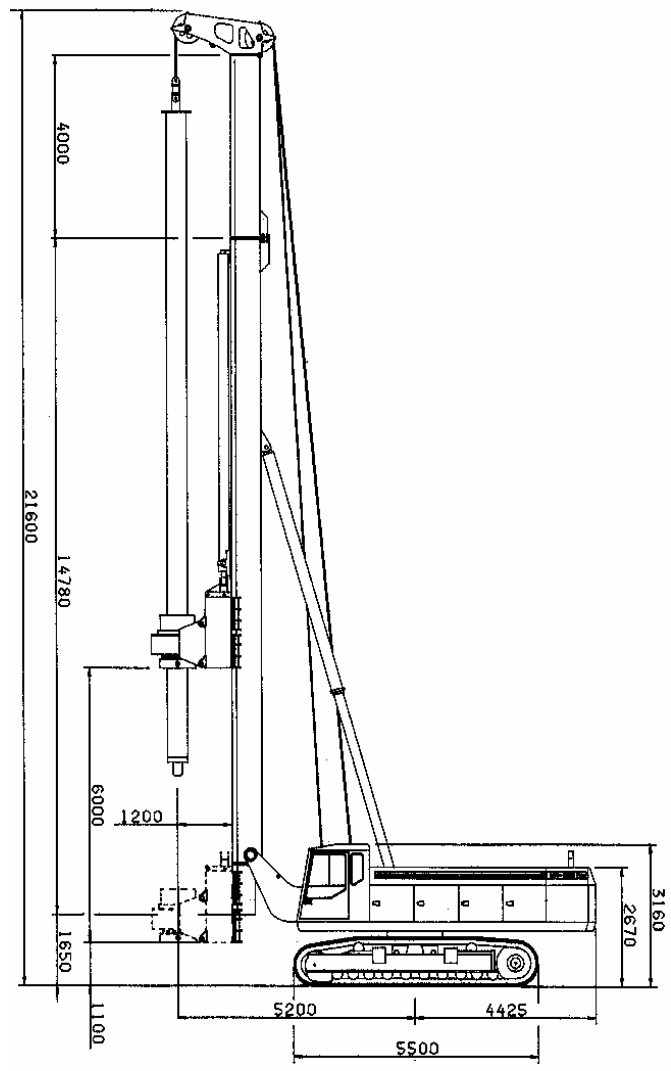

Figura 2.76 - HR 200 - Dimensões principais (MAIT, 98).

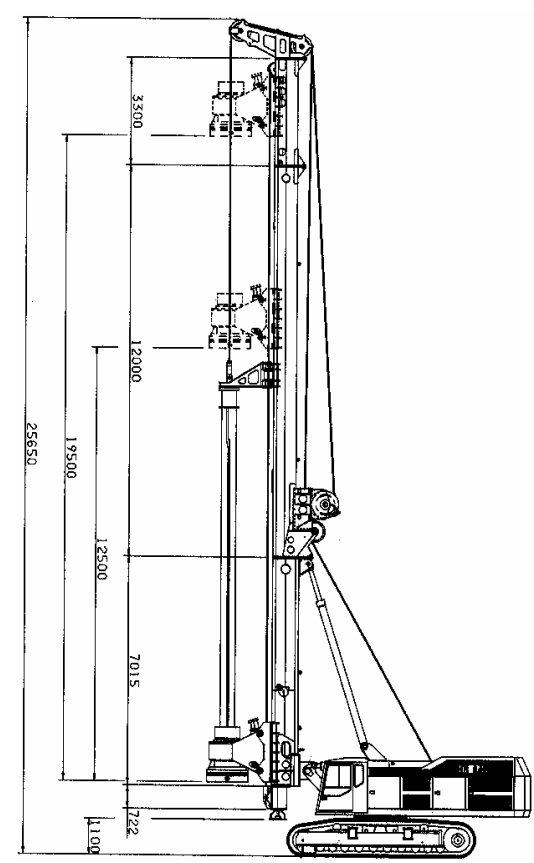

Figura 2.78 - HR 240 - Dimensões principais (MAIT, 98). 


\subsection{EQUIPMENTO CFA 24}

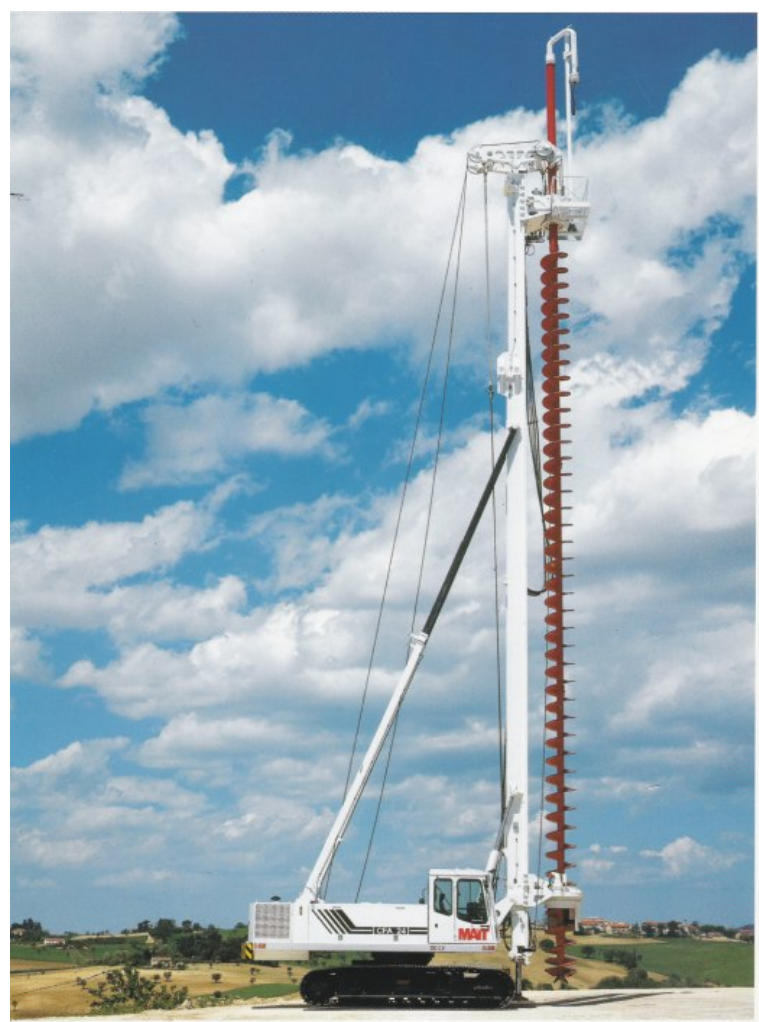

Figura 2.79 - Equipamento CFA 24 (MAIT, 98).

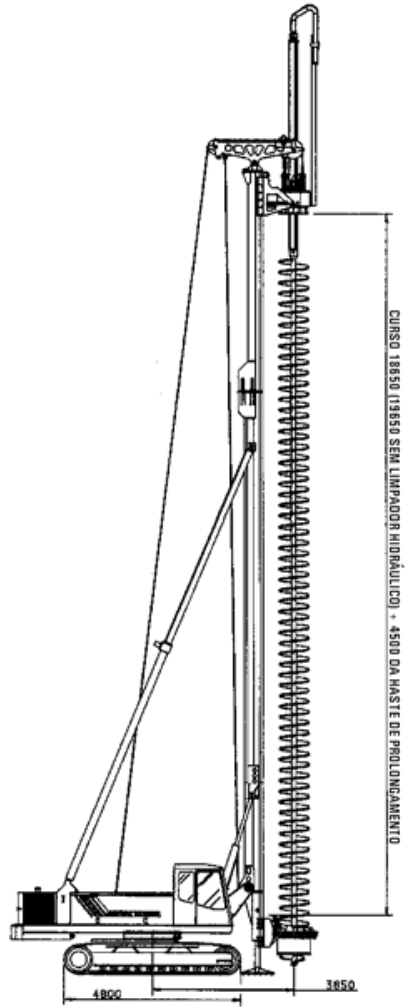

Figura 2.80 - CFA 24 - Dimensões principais (MAIT, 98).

Apresentam-se na Tabela 2.6 os dados técnicos dos equipamentos MAIT

Tabela 2.6 - DADOS TÉCNICOS DOS EQUIPAMENTOS MAIT

\begin{tabular}{llllllllll}
\hline \multicolumn{1}{c}{ Descrição } & $\mathrm{un}$ & $\mathrm{EB}$ & $\mathrm{HR}$ & $\mathrm{HR}$ & $\mathrm{HR}$ & $\mathrm{HR}$ & $\mathrm{HR}$ & $\mathrm{HR}$ & CFA \\
& & 12 & 45 & 110 & 130 & 160 & 200 & 240 & 24 \\
\hline Motor a diesel & $\mathrm{kW}$ & 94 & 62 & 137 & 170 & 246 & 289 & 333 & 170 \\
Peso do equipamento & $\mathrm{kN}$ & $* * *$ & 160 & $300 *$ & 350 & $* * *$ & $1200 *$ & $1350 *$ & 390 \\
Diâmetro máximo da estaca & $\mathrm{m}$ & 0,80 & 0,25 & 0,80 & 0,80 & 1,20 & 1,20 & 1,50 & 0,80 \\
Profundidade máxima de escavação & $\mathrm{m}$ & 14,0 & 12,0 & 10,5 & 18,0 & 24,0 & 32,0 & 35,0 & 19,5 \\
Torque nominal na mesa rotativa & $\mathrm{kNm}$ & 120 & 46 & 130 & 131 & 180 & 220 & 242 & 131 \\
Rotações na saída da mesa rotativa & $\mathrm{Rpm}$ & $* * *$ & $* * *$ & $* * *$ & $11-35$ & $* * *$ & $* * *$ & $11-32$ & $11-34$ \\
Tração no cabo do guincho principal & $\mathrm{kN}$ & 105 & 70 & 140 & 140 & 164 & 200 & 200 & 120 \\
Tração na hélice durante a extração & $\mathrm{kN}$ & 420 & 280 & 560 & 560 & 656 & 800 & 800 & 480 \\
Velocidade no guincho (linha simples) & $\mathrm{m} / \mathrm{s}$ & $* * *$ & $* * *$ & $* * *$ & $* * *$ & $* * *$ & $* * *$ & $* * *$ & $* * *$ \\
Velocidade max. de extração da hélice & $\mathrm{m} / \mathrm{s}$ & $* * *$ & $* * *$ & $* * *$ & $* * *$ & $* * *$ & $* * *$ & $* * *$ & $* * *$ \\
Tração no guincho auxiliar & $\mathrm{kN}$ & $* * *$ & $* * *$ & $* * *$ & $* * *$ & $* * *$ & $* * *$ & $* * *$ & $* * *$ \\
Velocidade do guincho auxiliar & $\mathrm{m} / \mathrm{s}$ & $* * *$ & $* * *$ & $* * *$ & $* * *$ & $* * *$ & $* * *$ & $* * *$ & $* * *$ \\
\hline
\end{tabular}

*** Valores não informados pelo fabricante

* Valores aproximados 


\subsubsection{EQUIPAMENTOS IMT}

IMT é a sigla da empresa italiana Industria Mecânica Trivelle, fundada em 1974. Seu fundador, Giulio Accorroni estuda o setor de perfuratrizes desde 1954 quando sua primeira perfuratriz foi construída. A seguir são apresentadas as principais perfuratrizes produzidas pela empresa.

\subsection{EQUIPAMENTO AF 12}

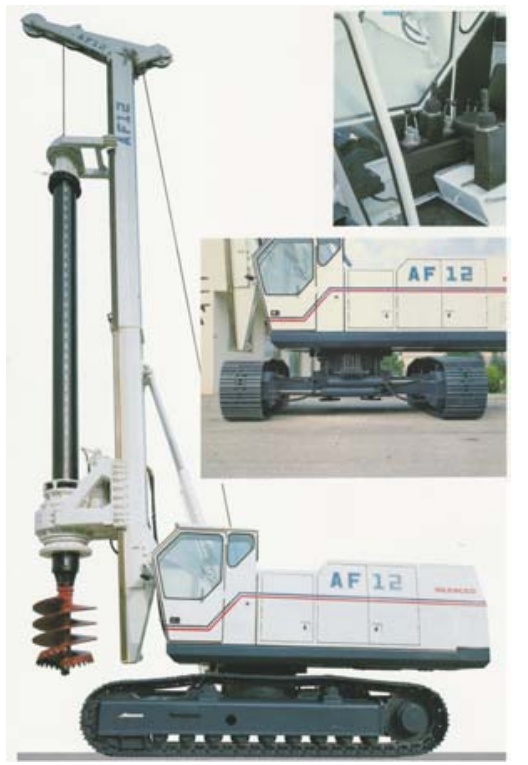

Figura 2.81 - Equipamento AF 12 (IMT, 1995).

\subsection{EQUIPAMENTO AF 16}

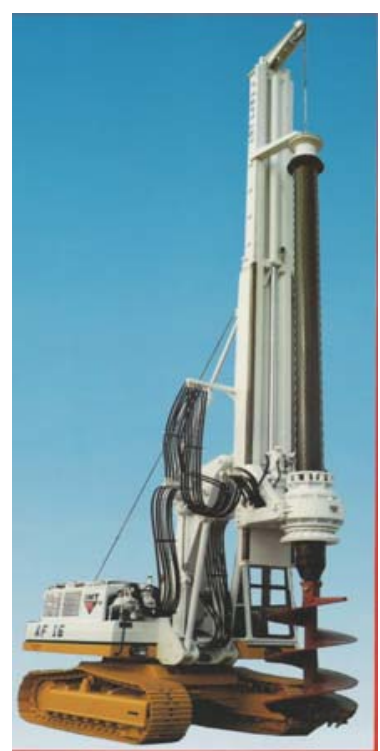

Figura 2.83 - Equipamento AF 16 (IMT, 1995).

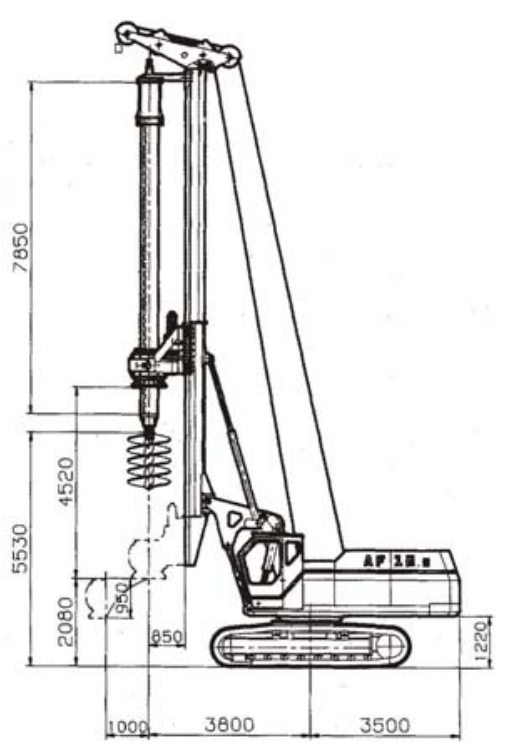

Figura 2.82 - AF 12 - Dimensões principais (IMT, 1995).

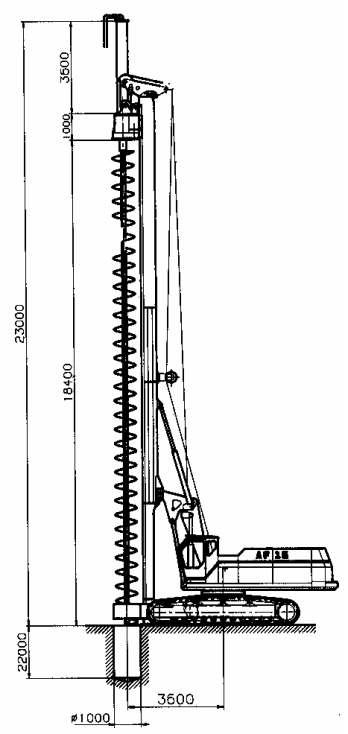

Figura 2.84 - AF 16 - Dimensões principais (IMT, 1995). 


\subsection{ESCAVAÇÃO COM TRADOS TUBULARES (HOLLOW-AUGER)}

Segundo Tomlinson (1994), uma estaca concretada no local após ter sido escavada por um processo qualquer de perfuração, é chamada de estaca escavada. De acordo com esse conceito, as estacas “Hollow Auger” nada mais são que estacas escavadas. Embora este tipo de estaca seja pouco mencionado na literatura, interessa ser aqui comentado, pelo fato de existir alguma semelhança com a estaca hélice segmentada.

Parece então, razoável definir a estaca do tipo “Hollow Auger” como um tipo de estaca escavada, moldada in loco, que consiste na introdução no terreno, de pequenos segmentos de trados até que o primeiro segmento introduzido no solo, o qual é provido de uma tampa de proteção em sua extremidade, atinja a cota de apoio da estaca.

Esses segmentos normalmente possuem comprimentos variáveis de 1,0 a 2,0 m. O processo difere da estaca tipo hélice contínua no seguinte:

- O trado é segmentado, sendo que as emendas dos segmentos são feitas durante a fase de escavação e o retorno à condição de segmentos isolados ocorre durante a fase de concretagem.

- O tubo central possui diâmetro interno maior que o usado para a estaca hélice contínua.

- A altura da hélice, que corresponde à diferença entre o raio da estaca e o raio externo do tubo central, é menor que no trado da estaca hélice contínua.

- O concreto é lançado do nível do terreno, com auxílio de um funil, para o interior do tubo central.

- O concreto lançado não é pressurizado.

- Não é utilizado nenhum monitoramento durante o processo.

A Figura 85 mostra a perfuratriz modelo B1F da empresa WIRTH Latina S.A., operando com trados ocos. Observa-se que a lâmina da hélice tem altura reduzida e que o diâmetro interno do tubo central tem uma importante dimensão. Essa geometrica é utilizada para que a relação entre a área da seção transversal da estaca e a área da seção transversal do furo central seja a menor possível. Com isso torna-se possível a extração do trado sem necessidade de monitoramento. Essa metodologia de execução de estacas é muito pouco utilizada pelo fato do processo ser extremamente lento. A aplicação é concretizada em locais de difícil acesso e onde há necessidade de execução da perfuração sem introdução de água. 


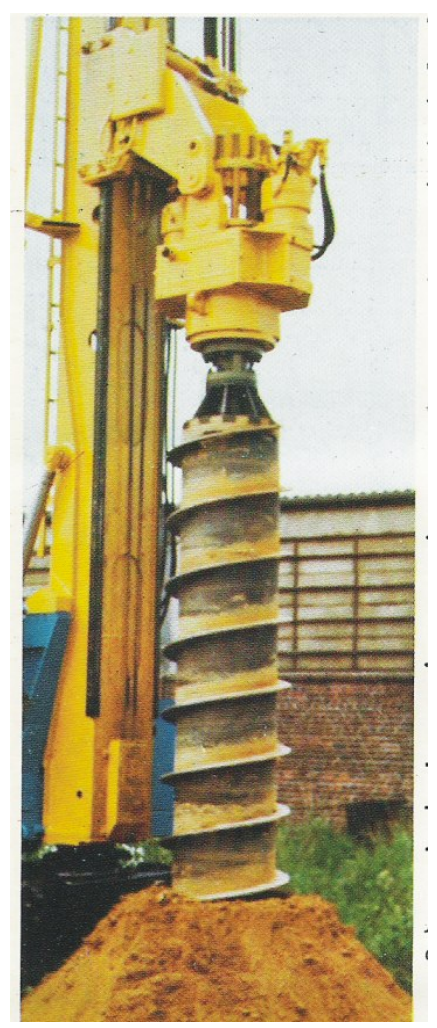

A empresa Cló Zironi disponibiliza a seus clientes a utilização do sistema "Hollow Auger” em seus equipamentos CR 12, CR 14 e CR 18 que são fabricados com a função principal de executar estacas do tipo "Raiz” (Figura 2.86). As empresas BS tubos, a MAC-SONDA e a Metalúrgica Wolf também fabricam, no Brasil, equipamentos semelhantes.

As empresas BS tubos, a MAC-SONDA e a Metalúrgica Wolf também fabricam, no Brasil, equipamentos semelhantes. A empresa E.G.Barreto oferece dois tipos de equipamentos, sobre rodas de pneus, que executam estacas escavadas, tubulões e estacas do tipo "Hollow Auger”. Os trados ocos são muito utilizados para a realização de ensaios de campo.

Figura 2.85 - Estaca com Trado Oco (Wirth, 19--?).

A Figura 2.87 mostra o equipamento HT 710 da E.G.Barreto, executando sondagens em um aterro sanitário na cidade de Leme-SP.

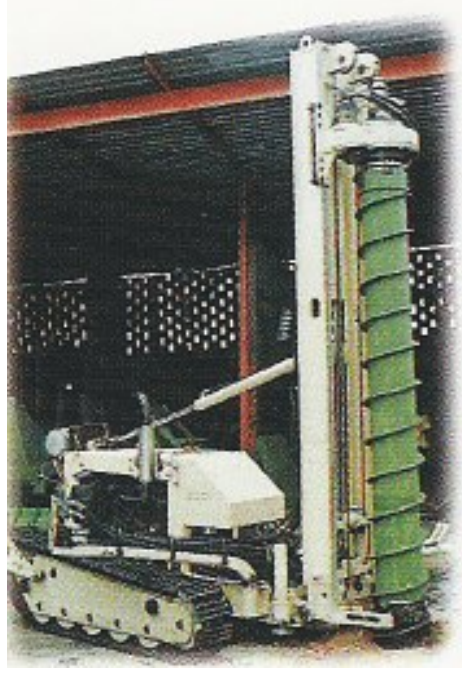

Figura 2.86 -Equipamento sobre esteiras com trado "hollow-auger" (Cló Zironi, 199-?).

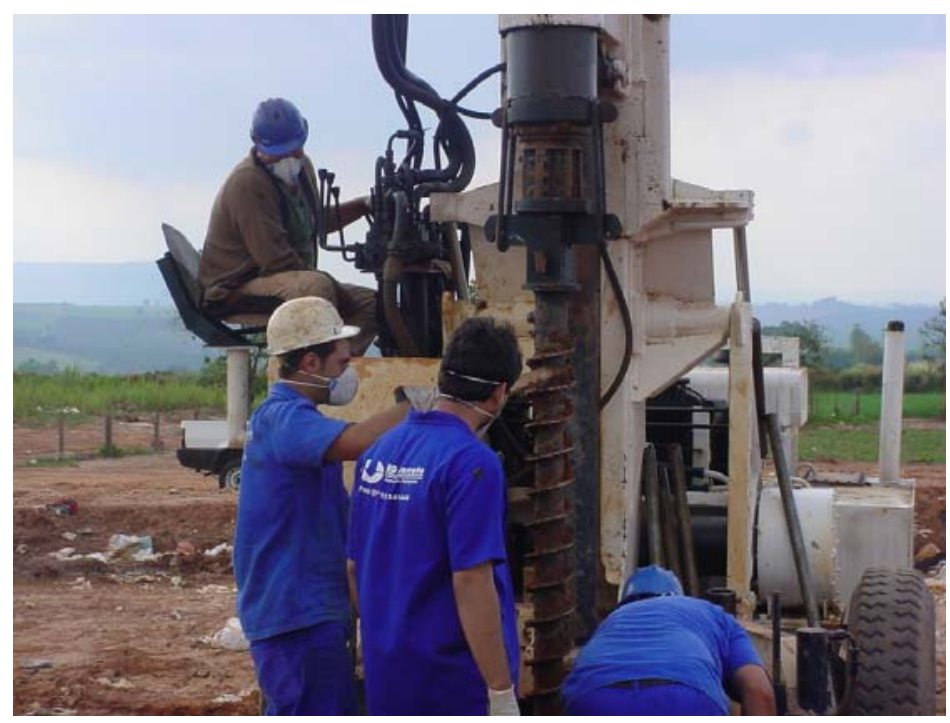

Figura 2.87 - Perfuratriz HT 710 -Execução de sondagens em aterro sanitário, na cidade de Leme - SP (E.G.Barreto, 2004). 
A empresa Alphageos, situada na cidade de Barueri-SP, especializada em geotecnia e geologia de engenharia possui dois equipamentos adquiridos da empresa americana CME (Figura 2.88). Esses equipamentos, executam sondagens SPT e rotativas, poços de monitoramento do lençol freático e outros ensaios.

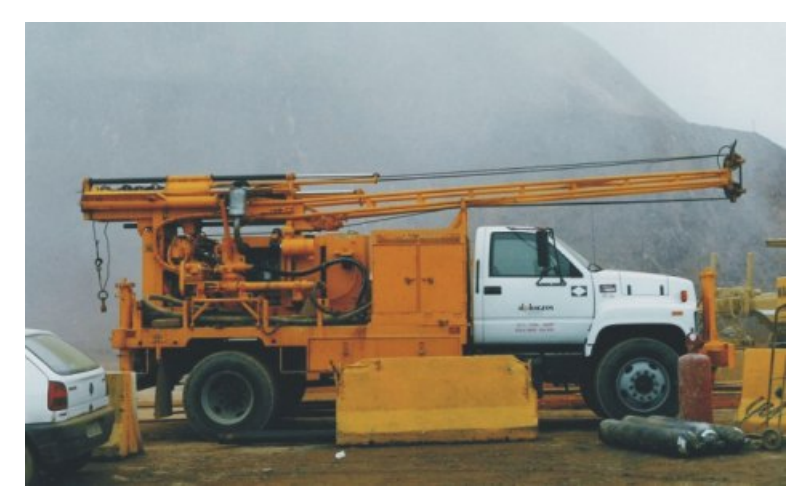

Figura 2.88 - Sonda CME 55 - Utiliza trados ocos Cortesia Alphageos (2000).

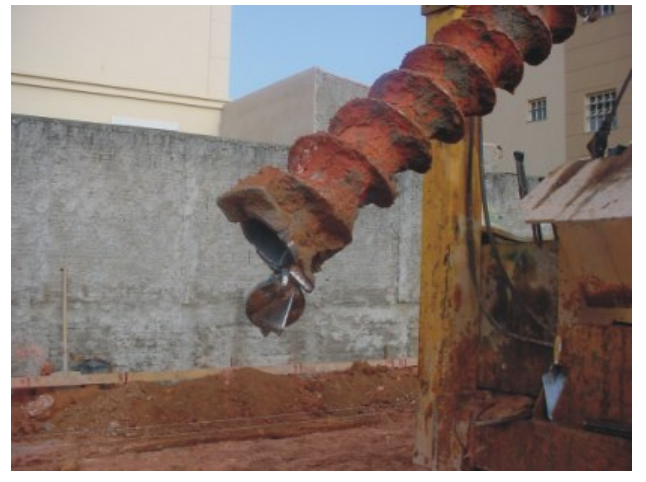

Figura 2.89 - Trado do tipo "Hollow Auger" Detalhe da tampa de proteção da ponta (E.G.Barreto, 2003).

Na Figura 2.89 vê-se o detalhe da tampa de proteção da ponta do trado. Essa tampa é semelhante às utilizadas nos trados para estacas hélice contínua, diferenciando-se apenas nas suas dimensões que são maiores devido ao diâmetro interno do tubo central.

\subsection{ESTACAS ESCAVADAS DE GRANDE DIÂMETRO}

Geralmente estacas escavadas com diâmetros maiores ou iguais a $0,60 \mathrm{~m}$ são consideradas de grande diâmetro. Elas podem atingir diâmetro de até $3 \mathrm{~m}$ e profundidades da ordem de $70 \mathrm{~m}$. Normalmente são utilizadas em obras civis e industriais nas quais as cargas nos elementos de fundações são bastante elevadas.

A substituição das mesas rotativas antigas, acopladas a guindastes de manuseio difícil, por equipamentos mais modernos e compactos, principalmente aqueles que permitem a execução de estacas escavadas inclinadas, a cravação por rotação de camisas metálicas perdidas ou recuperáveis e a possibilidade de engastamento em rocha, possibilita em muitos casos a substituição técnica e economicamente viável em estacas cravadas pré-moldadas, metálicas e tubulões a ar comprimido (FUNDESP, 2001).

São comuns escavações profundas e com cotas de apoio da estaca bem abaixo do lençol freático, para que as cargas da estrutura possam ser transferidas para o maciço, com a segurança requerida. Quando não é utilizado tubo de revestimento, emprega-se lama bentonítica que tem a função de garantir a estabilidade do furo além de manter em suspensão os detritos provenientes da desagregação do terreno. Se a opção de projeto for 
não utilizar lama bentonítica, os tubos metálicos de revestimento devem ser utilizados. As Figuras 2.90 e 2.91 mostram, respectivamente, os esquemas de execução de estacas de grande diâmetro sem e com a utilização de camisa metálica (revestimento).

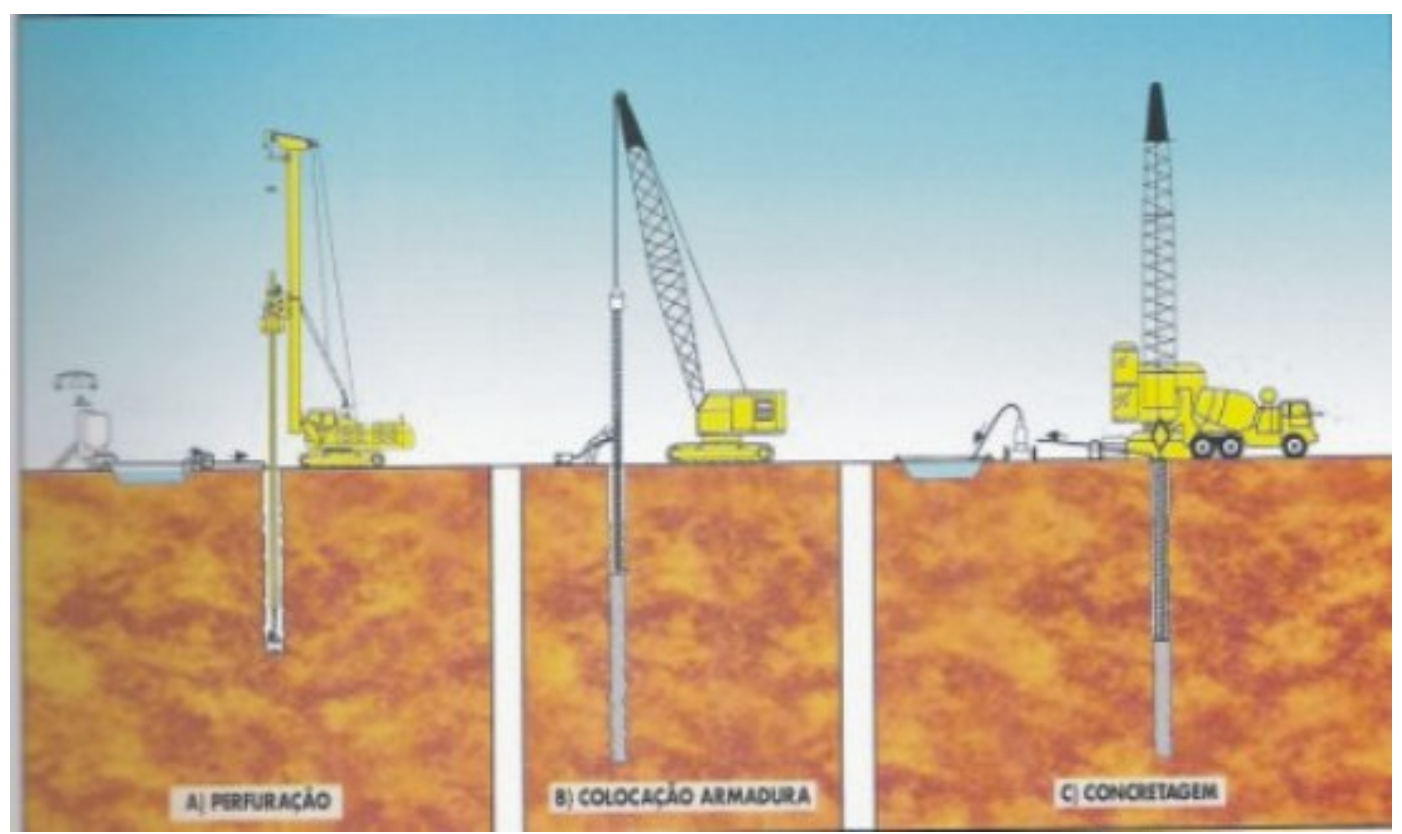

Figura 2.90 - Esquema de execução de estacas de grande diâmetro Com utilização de lama bentonítica (FUNDESP, 2001).

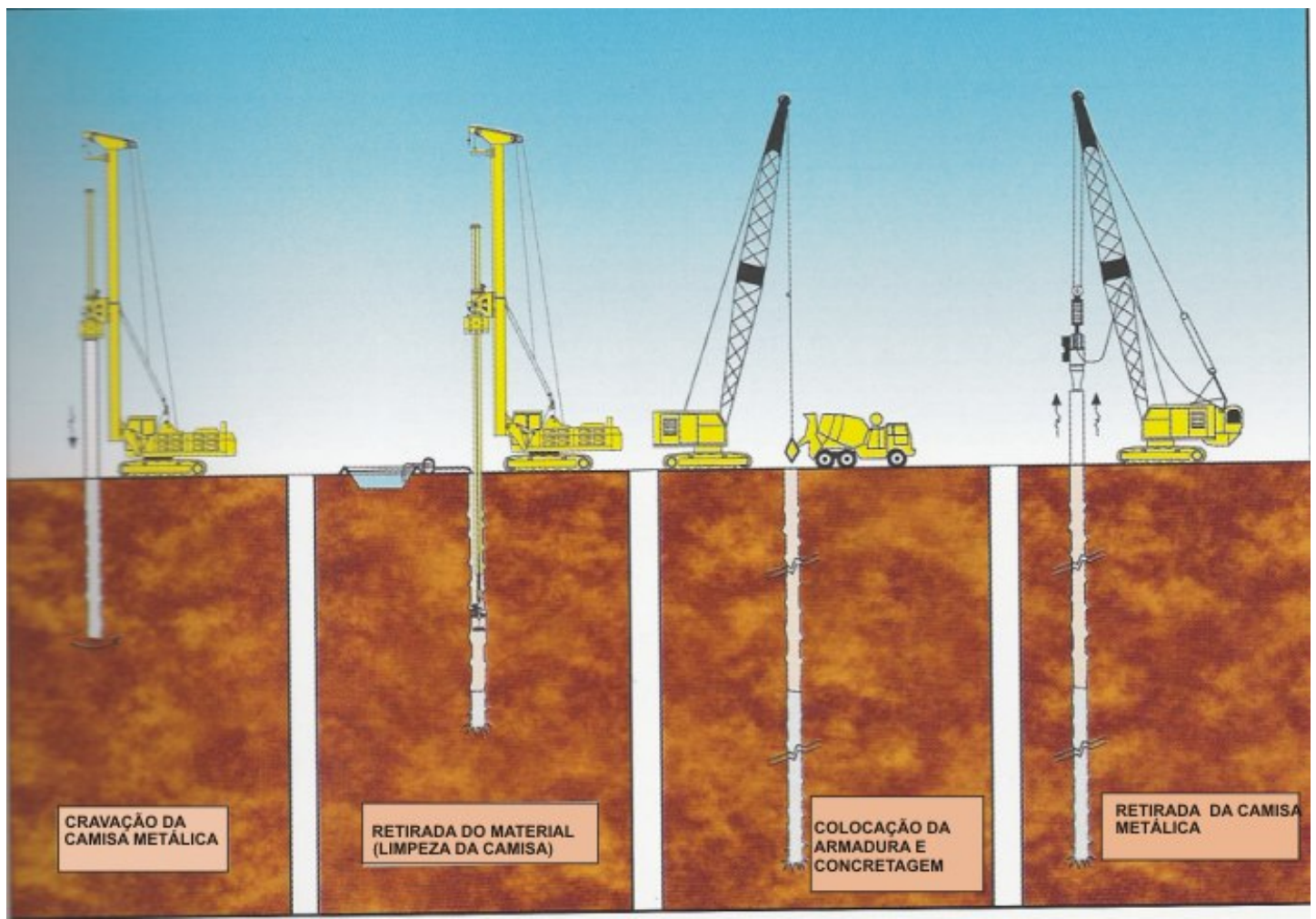

Figura 2.91 - Esquema de execução de estacas de grande diâmetro com utilização de camisa metálica (FUNDESP, 2001). 


\subsection{ESTACAS HÉLICE SEGMENTADA}

\subsubsection{EQUIPAMENTOS EXISTENTES}

Diversos modelos de equipamentos para execução de estacas do tipo "hélice segmentada” estão começando a ser produzidos na Itália pela empresa EGTECHNOLOGY. A linha “MD” é formada pelos modelos MD 700_3; MD 700_4; MD 3000_1 e MD 7000_1. Esses equipamentos foram inicialmente projetados para executar estacas tipo raiz, injeções, drenos verticais e horizontais, tirantes etc., e há apenas poucos anos estão sendo adaptados para a execução de estacas hélice segmentada.

No Brasil, a empresa ENGESTRAUSS situada na cidade de Santo André foi a primeira a importar um dos modelos fabricados (Figura 2.92). Esse modelo (MD 3000) opera com um segmento sempre acoplado ao cabeçote de perfuração e até outros dois, em um mecanismo denominado alimentador, responsável pelas emendas necessárias para que o trado vá se tornando contínuo da superfície do solo para baixo. A Figura 2.93 mostra o equipamento operando com um segmento de $6 \mathrm{~m}$ na mesa rotativa (cabeçote de perfuração) e apenas um no alimentador, também de $6 \mathrm{~m}$.

Essa condição é possível em obras onde os comprimentos das estacas não ultrapassam $12 \mathrm{~m}$.

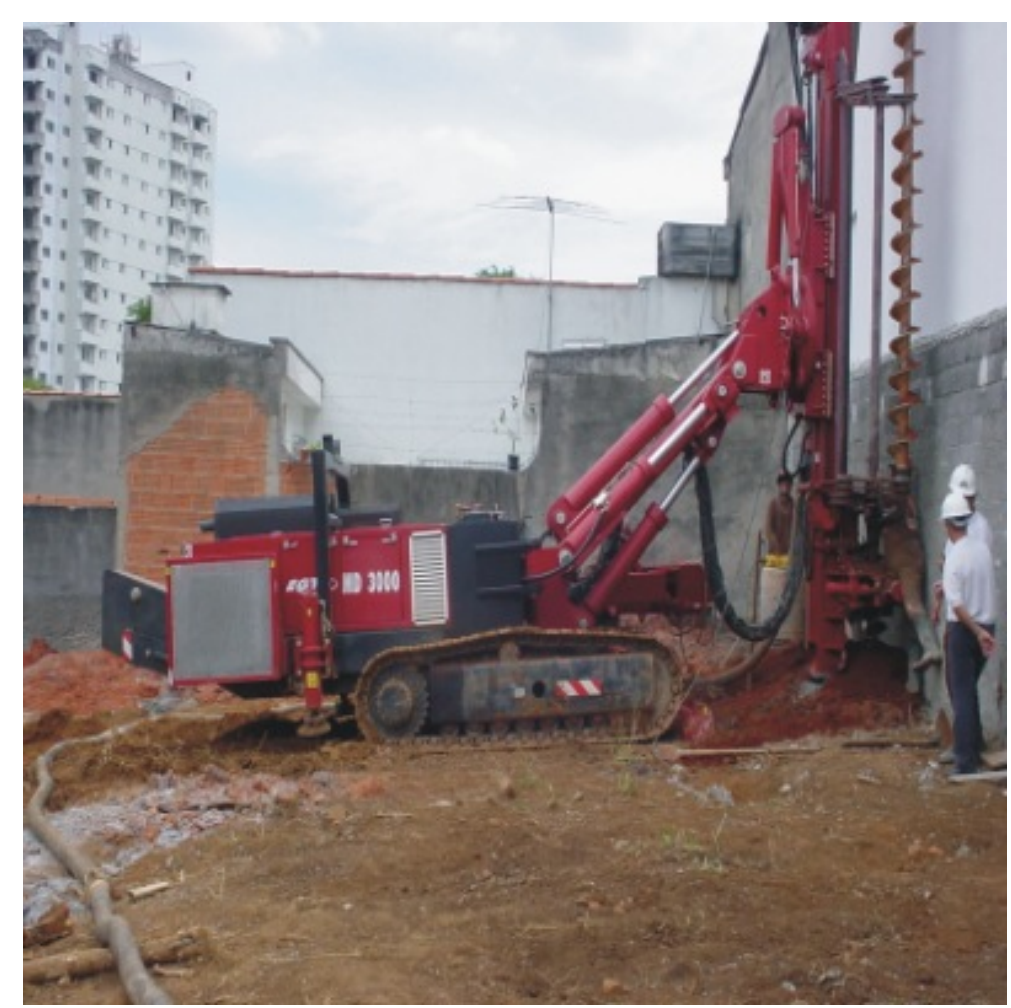

Figura 2.92 - Perfuratriz MD-3000 (EGTECHNOLOGY, 2002). 


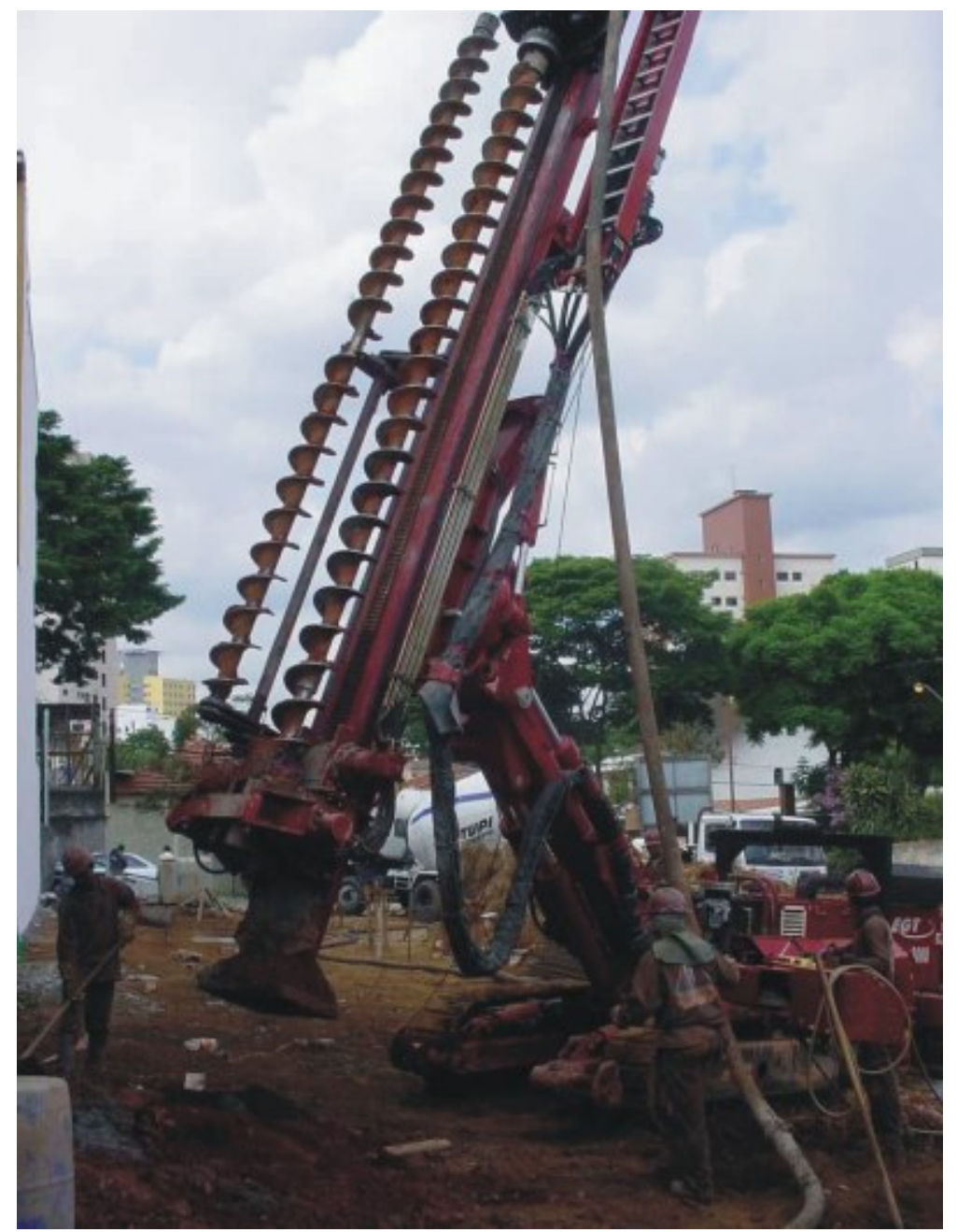

Figura 2.93 - MD 3000 - Mecanismo alimentador de trades segmentados (EGTECHNOLOGY, 2002).

\subsubsection{PROCESSO EXECUTIVO}

É semelhante ao processo utilizado para a execução de estaca hélice contínua convencional, sendo as seguintes as diferenças básicas entre os dois processos:

- Os trados são instalados no terreno em segmentos que são acoplados um a um, normalmente na vertical, formando um trado contínuo da superfície do terreno até a cota de apoio da estaca.

- Os segmentos são montados uns sobre os outros, para cada estaca que é executada, e um mecanismo denominado alimentador de trados pode ser utilizado para facilitar essa operação.

- A concretagem é iniciada logo após o término da escavação com a extração simultânea da hélice que na medida que vai sendo retirada, os segmentos são retornados para o mecanismo alimentador. 
O monitoramento eletrônico que os italianos estão usando é o mesmo que normalmente equipa os equipamentos convencionais de hélice contínua.

O desenvolvimento de equipamentos e a utilização das estacas hélice segmentada estão apenas iniciando.

Outros equipamentos e ferramentas para fundações são desenvolvidos e comercializados em diversas partes do mundo. A seguir são mencionados alguns dos fabricantes:

- HUGH WILLIAMS com sede no estado da Virginia, nos Estados Unidos.

- MORI s.r.l., empresa italiana instalada na Via Molino em Campofilone.

- BAUER Maschinen GmbH com sede na Alemanha.

- MAPER s.r.l., empresa italiana com sede em Osimo.

- EMDE, instalada na Alemanha.

- SEGOVIA s.l., com sede em Madrid.

- JUNTTAN com sede na Finlândia.

- Beretta Alfredo s.r.l., com sede na Itália.

- WIRTH Maschinen, com sede na Alemanha. 


\section{CAPÍTULO 3}

\section{CONSIDERAÇÕES GERAIS SOBRE O EQUIPAMENTO E PRINCIPAIS CONJUNTOS QUE O COMPÕE}

\subsection{CONCEPÇÃO}

O homem por ser eminentemente criativo, ao longo de sua existência tem inúmeras idéias. No entanto, em praticamente todas as áreas da atividade humana a materialização das idéias exige quase sempre, além de pessoas, a utilização de equipamentos adequados. No caso da engenharia geotécnica esse conceito também parece ser válido, já que o avanço dessa especialidade é dependente do desenvolvimento de novos equipamentos.

Este trabalho teve como objetivo básico o desenvolvimento de um equipamento para a execução de estacas hélice segmentada, estacas escavadas, tubulões e estacas com utilização de trados ôcos (Hollow-Auger). Optou-se pelo desenvolvimento de um equipamento multifunção com o objetivo de melhorar a relação "custo x beneficio" viabilizando a sua utilização em obras pequenas e médias.

A utilização da plataforma sobre pneus foi projetada com o intuito de diminuir custos em comparação com aquelas sobre esteiras, normalmente utilizadas nos equipamentos importados.

A utilização de trados segmentados apoiados em um sistema hidráulico de alimentação permitiu a redução da altura do equipamento se comparada com a altura necessária para a escavação na mesma profundidade máxima de 14,0 m com a utilização de trado contínuo.

O peso e dimensões reduzidos permitiram o acesso do equipamento a locais relativamente confinados, viabilizando a execução de estacas injetadas, sem a utilização de água no processo de escavação.

O equipamento produz estacas moldadas in loco, utilizando um processo que além de praticamente não provocar o desconfinamento do solo circundante, resulta em 
perturbações insignificantes às edificações vizinhas quando comparados com os equipamentos tradicionais que trabalham com processo percussivo.

O projeto do sistema de autocarregamento associado ao baixo peso do equipamento permitiu a utilização de caminhões comuns para o transporte, o que teve uma importante colaboração na queda dos preços para mobilização do equipamento.

A utilização de um misturador e de uma bomba de argamassa é interessante para a realização de obras em locais distantes de uma central de concreto e para obras de pequeno porte nas quais a utilização de concreto bombeável seria inviável do ponto de vista econômico.

O monitoramento das pressões de injeção com utilização de um manômetro digital ou analógico, torna o processo muito mais confiável com relação à integridade dos fustes das estacas. É, sem dúvida, um avanço tecnológico importante quando comparado, por exemplo, com as estacas do tipo strauss, em cujo processo se utilizam tubos de revestimento com ponta aberta (NBR 6122/96) inclusive abaixo do nível do lençol freático.

A geometria do equipamento associada à sua concepção permitiu o movimento da torre desde a posição horizontal até a posição vertical com todos os segmentos alojados no mecanismo alimentador de trados. Essa condição de projeto resultou em grande segurança nas operações de manobras, tendo em vista que as mesmas são feitas com a torre na posição horizontal ou levemente inclinada. Essa condição não é possível nos equipamentos de estacas pré-moldadas, nos equipamentos de estacas Franki e nos equipamentos de estacas hélice contínua, nos quais as manobras de uma estaca para outra são feitas com as torres na posição vertical ou próxima dela (ABEF, 1999).

A facilidade de manutenção associada ao menor custo dos componentes nacionais em relação aos importados e a característica multifuncional da perfuratriz, provavelmente resultará em grande interesse pelo equipamento, por parte das empresas executoras de fundações.

Nas obras pequenas e com cargas verticais nas estacas de até 300 kN, a redução do custo das fundações em relação a outros tipos de estacas, será um atrativo importante para as empresas construtoras.

A qualidade de condições no trabalho ficará privilegiada em relação a outros equipamentos já que tanto o operador quanto os ajudantes irão desempenhar suas funções em condições plenamente satisfatórias do ponto de vista de segurança e de conforto no trabalho. 


\subsection{CONSIDERAÇÕES SOBRE AS CARACTERÍSTICAS TÉCNICAS DO EQUIPAMENTO}

A plataforma da perfuratriz tem dimensões em planta de $2554 \mathrm{~mm}$ de largura e 6010 mm de comprimento quando os cilindros expansores (Figura 3.12) estão com as hastes recolhidas e $3602 \mathrm{~mm}$ x $6010 \mathrm{~mm}$ quando os cilindros expansores estão com as hastes na posição estendida. Essas dimensões tornaram-se viáveis do ponto de vista da estabilidade do equipamento, devido à sua altura de 9,695 m, com a torre na posição vertical.

O motor diesel utilizado, modelo TD 229-EC-6 da empresa MWM do Brasil fornece 92 kW (125 CV) a 1800 rpm. Trata-se de um motor muito utilizado em nosso país devido à facilidade de peças de reposição, além de sua qualidade inquestionável. Da mesma forma a maioria dos componentes utilizados, embora de empresas multinacionais, são fabricados em nosso país. Exemplos desses componentes são: aços planos, perfis metálicos, rolamentos, engrenagens, elementos de fixação, elementos de vedação, válvulas hidráulicas, tubos e conexões hidráulicas, mangueiras hidráulicas, filtros, bombas hidráulicas, cilindros hidráulicos, entre outros componentes.

$\mathrm{O}$ peso de aproximadamente $140 \mathrm{kN}$ faz da perfuratriz um equipamento muito atraente já que sendo autocarregável e leve, pode ser transportada em caminhões comuns.

A utilização de dois motores hidráulicos de pistões radiais de duplo deslocamento volumétrico (500 $\mathrm{cm}^{3} /$ rotação e $250 \mathrm{~cm}^{3} /$ rotação), combinados com duas bombas hidráulicas com deslocamento volumétrico de $105 \mathrm{~cm}^{3} /$ rotação, possibilitaram a oferta de três rotações no eixo de saída do cabeçote rotativo. A 28 rpm o torque é de $22 \mathrm{kNm}$, a $56 \mathrm{rpm}$ obtém-se $11 \mathrm{kNm}$ e a $112 \mathrm{rpm}$ o torque é de 5,5 kNm. A velocidade mais baixa é utilizada para a execução de estacas hélice segmentada nos diâmetros de $25 \mathrm{~cm}$ e $30 \mathrm{~cm}$ até $14 \mathrm{~m}$ de profundidade e estacões e tubulões com diâmetros de até 1,20 m e profundidade de até $22 \mathrm{~m}$. Na velocidade intermediária executam-se estacas escavadas de pequenos diâmetros até $22 \mathrm{~m}$ de profundidade e a velocidade mais elevada é utilizada para limpeza do trado (disparo) quando se escavam estacas ou tubulões.

O cilindro de empuxo axial instalado na torre trabalha normalmente com pressões variáveis de 100 a 140 bar e tem capacidade para aplicar nos trados até, $70 \mathrm{kN}$ de esforço axial de compressão (pull-down) e $150 \mathrm{kN}$ de esforço axial de tração (pullback). 


\subsection{PRINCIPAIS CONJUNTOS QUE COMPÕE O EQUIPAMENTO}

A perfuratriz desenvolvida é formada de diversos subconjuntos que serão denominados simplesmente conjuntos. Cada conjunto pode ser formado por subconjuntos ou por componentes (peças) ou ainda por componentes e subconjuntos. Os componentes podem ter sido desenvolvidos pelo autor desta dissertação ou adquiridos no mercado brasileiro ou estrangeiro. Os componentes disponíveis no mercado são normalmente chamados de componentes comerciais.

Um esquema do equipamento com a identificação dos principais conjuntos é apresentado na Figura 3.1, com o objetivo de facilitar o entendimento das descrições que se seguem.

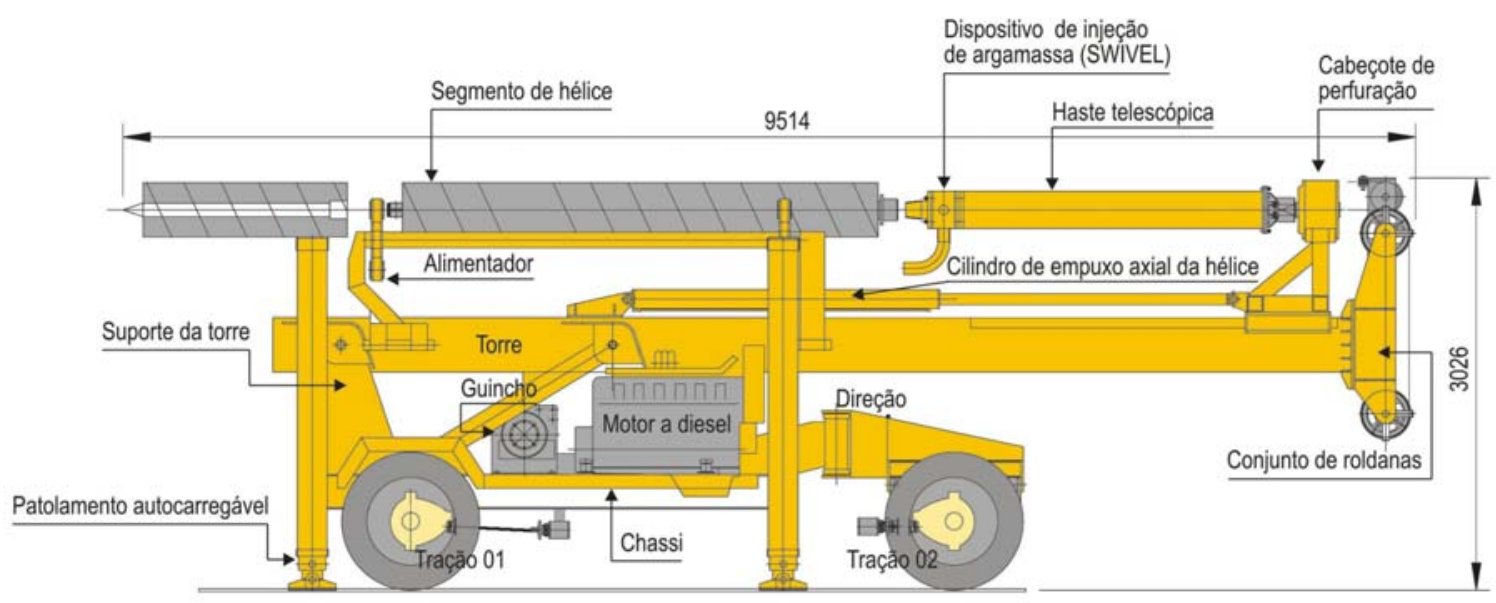

Figura 3.1 - Esquema da perfuratriz com torre na posição de manobra.

A seguir apresentam-se os principais conjuntos que formam a perfuratriz.

\subsubsection{CHASSI}

É constituído de uma estrutura metálica que se apóia na carcaça do diferencial veicular do sistema de tração (tração 01) e na mesa compensadora. No chassi são instalados o sistema de motorização, os comandos e bombas hidráulicas, os cilindros expansores, os cilindros de nivelamento (patolamento), o guincho principal, os reservatórios de óleo hidráulico e óleo diesel, os dois cilindros de giro da torre e a torre. A Figura 3.2 mostra uma vista do equipamento em que se vê a plataforma com os diversos conjuntos e componentes que sobre ela se apóiam. A plataforma é o nome dado ao conjunto composto pelo chassi, mesa compensadora, sistema de tração, 
cilindros de nivelamento e autocarregamento e cilindros expansores, sendo que cada um desses conjuntos será descrito neste capítulo.
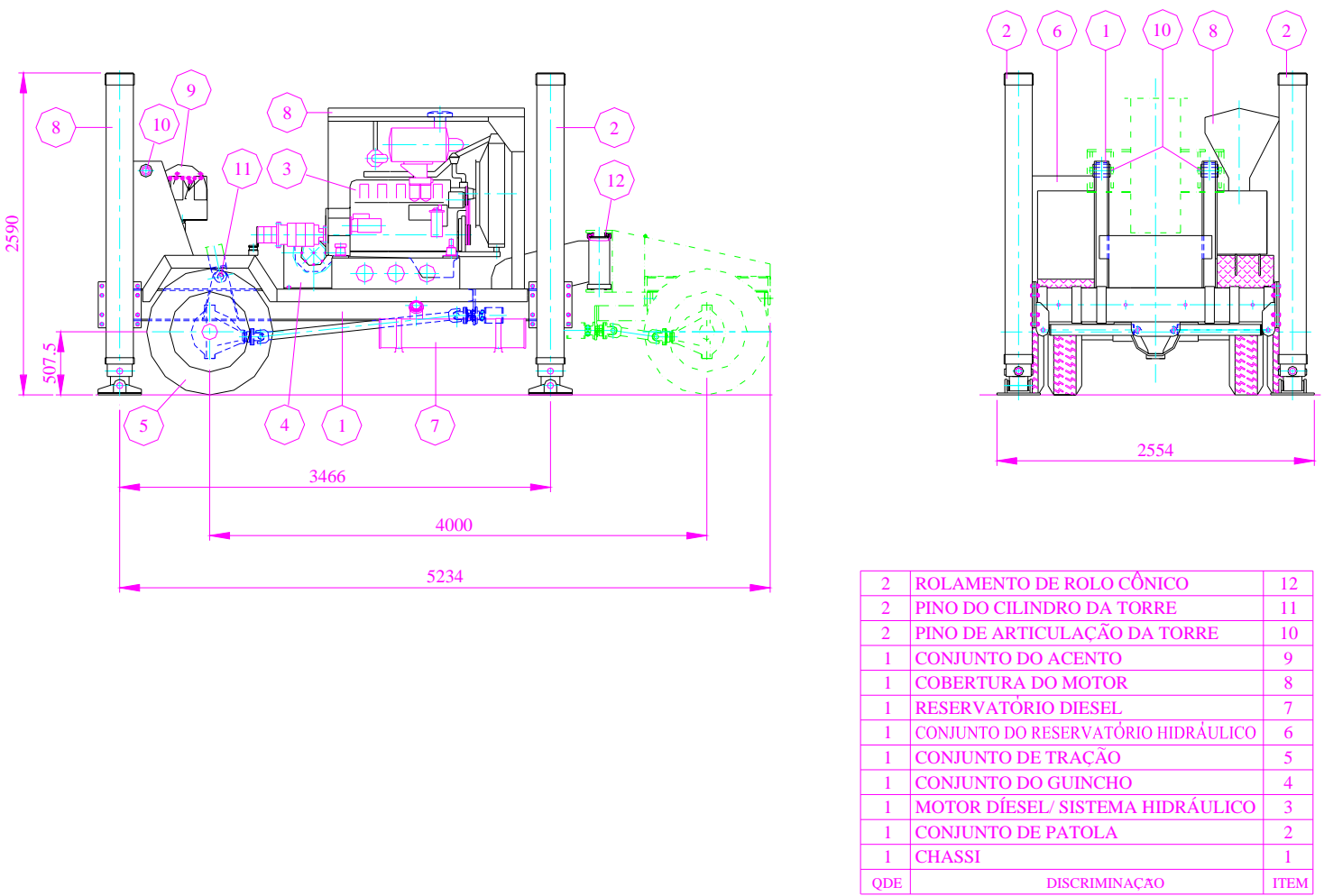

Figura 3.2 - Conjunto da plataforma.

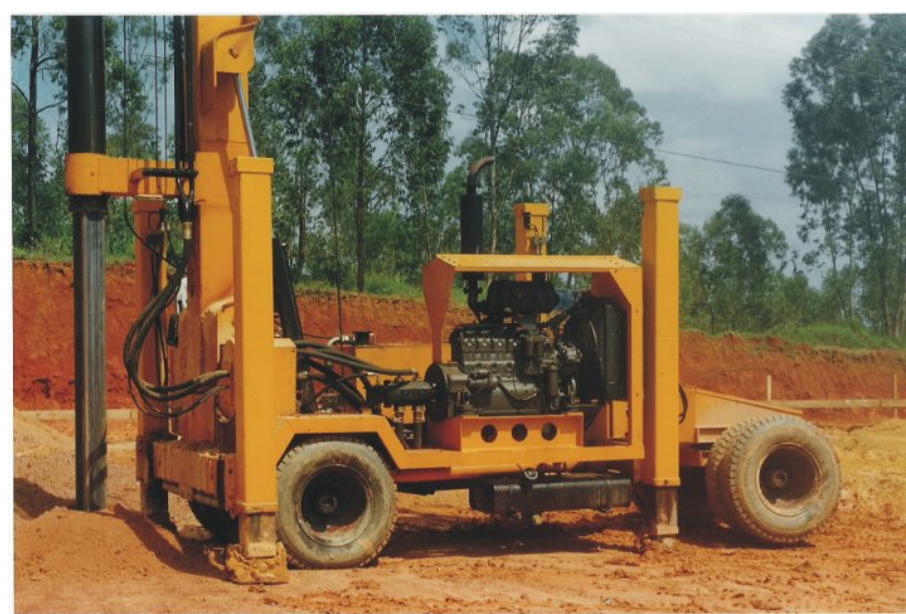

Figura 3.3 - Vista geral da plataforma.

A Figura 3.3 mostra uma foto da plataforma do equipamento.

\subsubsection{DIREÇÃO E MESA COMPENSADORA}

Este subconjunto é formado por uma estrutura metálica que se apóia no chassi e no sistema de tração posterior (tração 02). É ligado ao chassi por um sistema articulado que 
dá à plataforma a liberdade de movimento no plano horizontal. Tal movimento é conseguido com a utilização de dois cilindros acionados hidraulicamente. A estrutura metálica deste subconjunto pode ser basicamente dividida em duas partes:

a) a estrutura superior que é articulada ao chassi através de um pino vertical e à estrutura inferior através de dois pinos horizontais.

b) a estrutura inferior que se apóia no sistema de tração posterior (tração 02) e é articulada à estrutura superior.

A articulação da estrutura superior à inferior possibilita o movimento de rotação, no plano vertical, da estrutura inferior, a qual é fixa ao sistema de tração posterior (tração 02).

Como pode ser observado na Figura 3.4, a distância entre o eixo de articulação e o eixo do diferencial é igual a $866 \mathrm{~mm}$. Quando os pneus estão apoiados no solo e os cilindros da direção são acionados, o conjunto gira em torno dessa articulação vertical. A distância de $866 \mathrm{~mm}$, citada acima, é o valor da excentricidade das forças na articulação em relação ao apoio que é o solo sob os pneus do sistema de tração. A existência de atrito entre o solo e os pneus da tração 02 faz com que o chassi gire em torno da mesma articulação. Esse giro provoca um movimento do trado, no plano horizontal, facilitando o posicionamento da ponta do mesmo sobre a estaca a ser escavada.

As Figuras 3.4, 3.5 e 3.6 mostram, respectivamente, um desenho de conjunto da mesa compensadora, uma foto com detalhe do cilindro de articulação horizontal (direção hidráulica) e uma foto do sistema de articulação vertical.

O equipamento é autopropelido através de um sistema de tração constituído por dois diferenciais veiculares. Para cada diferencial um motor hidráulico é acoplado em seu eixo de entrada que quando acionado pela energia hidráulica, produz os movimentos, para frente e para traz, necessários às manobras do equipamento. Foram utilizados diferenciais de caminhão modelo 1313 da marca Mercedez Benz, sendo que em cada diferencial foram montadas 4 rodas com pneus. Como as bombas hidráulicas utilizadas são de vazões constantes, para uma determinada rotação, a velocidade de locomoção do equipamento é constante. Para a rotação de 1800 rpm, normalmente utilizada, a velocidade do equipamento é de aproximadamente $12,5 \mathrm{~m} / \mathrm{min}$. 

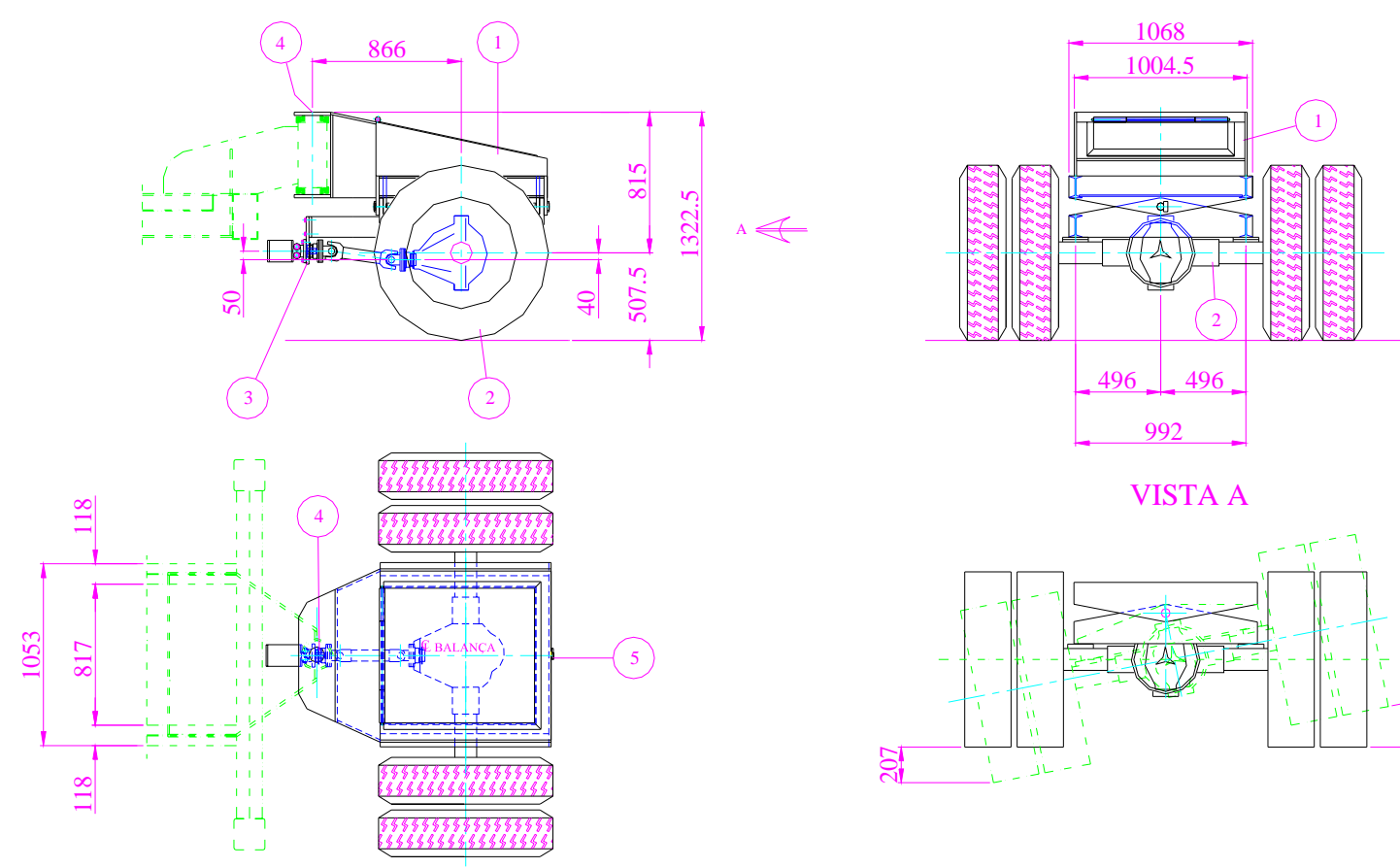

VISTA A

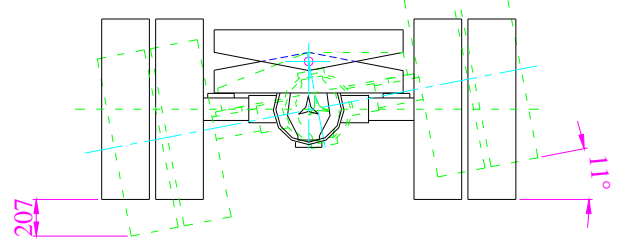

Figura 3.4 - Conjunto da mesa compensadora (balança).

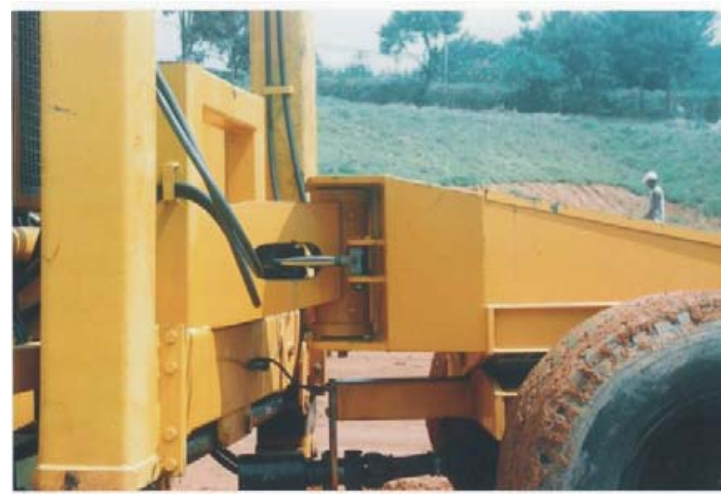

Figura 3.5 - Detalhe da direção hidráulica.

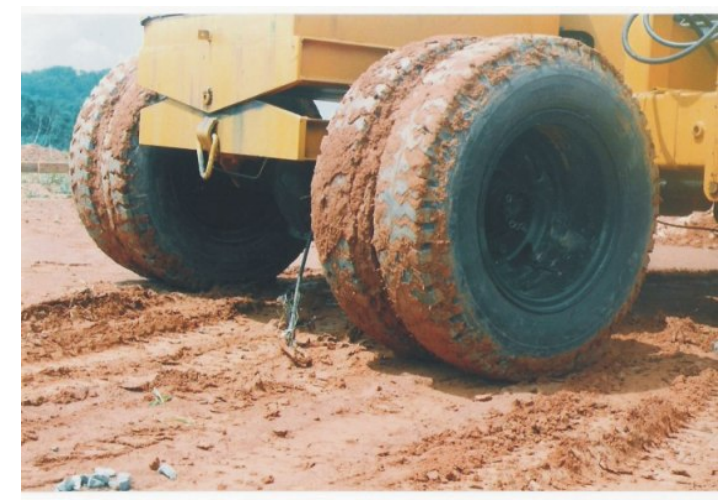

Figura 3.6 - Detalhe da articulação da mesa compensadora.

\subsubsection{SISTEMA DE TRAÇÃO}

Embora essa velocidade seja relativamente baixa, é suficiente para a movimentação da máquina de uma estaca para outra sem grande perda de tempo tendo em vista que normalmente os espaçamentos entre estacas não são muito grandes. Por outro lado, velocidades maiores não seriam recomendadas, pois poderiam comprometer a segurança durante as operações de manobra.

A Figura 3.7 apresenta um desenho do sistema de tração. 

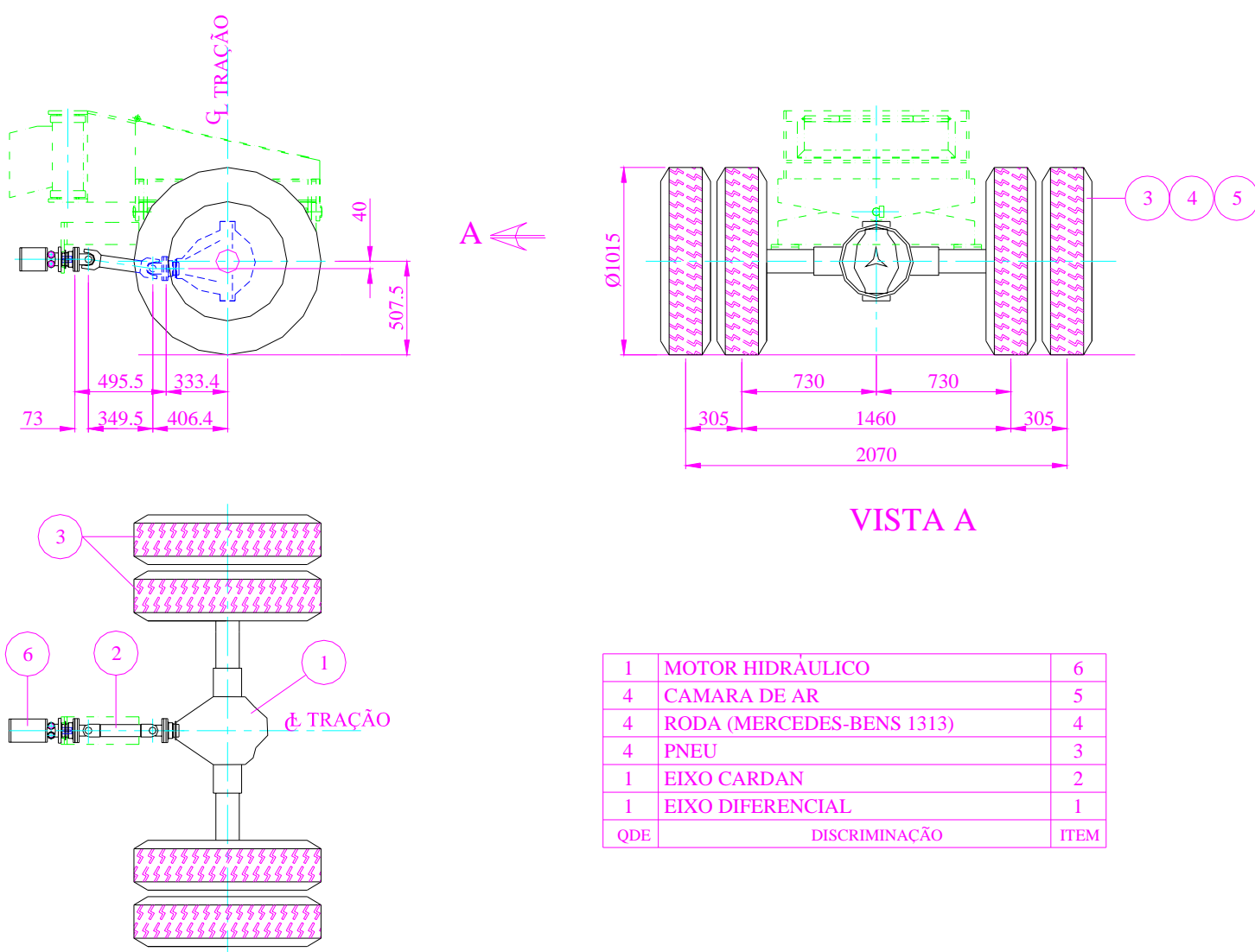

VISTA A

\begin{tabular}{|c|c|c|}
\hline 1 & MOTOR HIDRÁULICO & 6 \\
\hline 4 & CAMARA DE AR & 5 \\
\hline 4 & RODA (MERCEDES-BENS 1313) & 4 \\
\hline 4 & PNEU & 3 \\
\hline 1 & EIXO CARDAN & 2 \\
\hline 1 & EIXO DIFERENCIAL & 1 \\
\hline QDE & DISCRIMINAÇÃO & ITEM \\
\hline
\end{tabular}

Figura 3.7 - Conjunto de tração.

\subsubsection{SISTEMA DE NIVELAMENTO E AUTOCARREGAMENTO}

Oito cilindros, quatro verticais e quatro horizontais, formam o sistema de nivelamento que também servem para executar o carregamento do equipamento. Esse sitema é normalmente conhecido na prática da engenharia como "Patolamento hidráulico” (Figura 3.8). Cada conjunto de nivelamento é formado pelos seguintes subconjuntos:
a) Estrutura do cilindro vertical.
b) Cilindro vertical.
c) Cilindro horizontal.
d) Haste telescópica horizontal.
e) Chapa de patolamento.
f) Pino. 

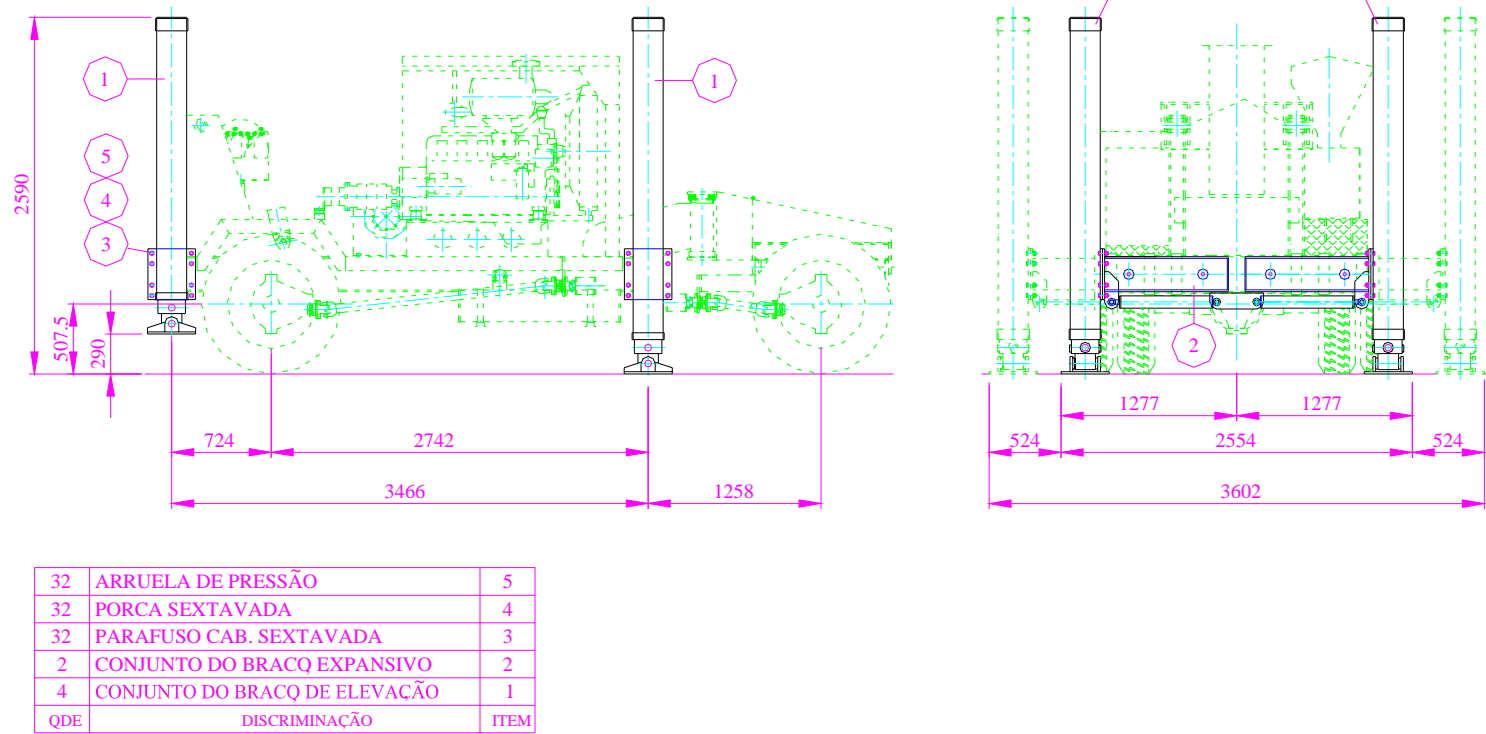

Figura 3.8 - Sistema de nivelamento e autocarregamento.

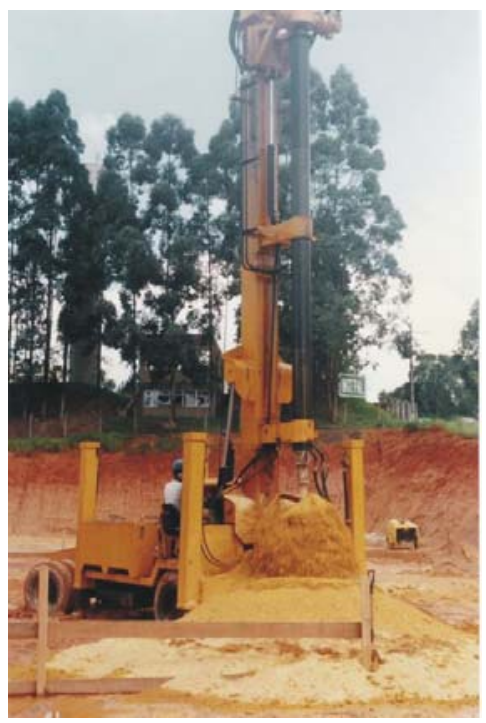

Figura 3.9 - Equipamento com os quatro apoiados cilindros apoiados no solo.

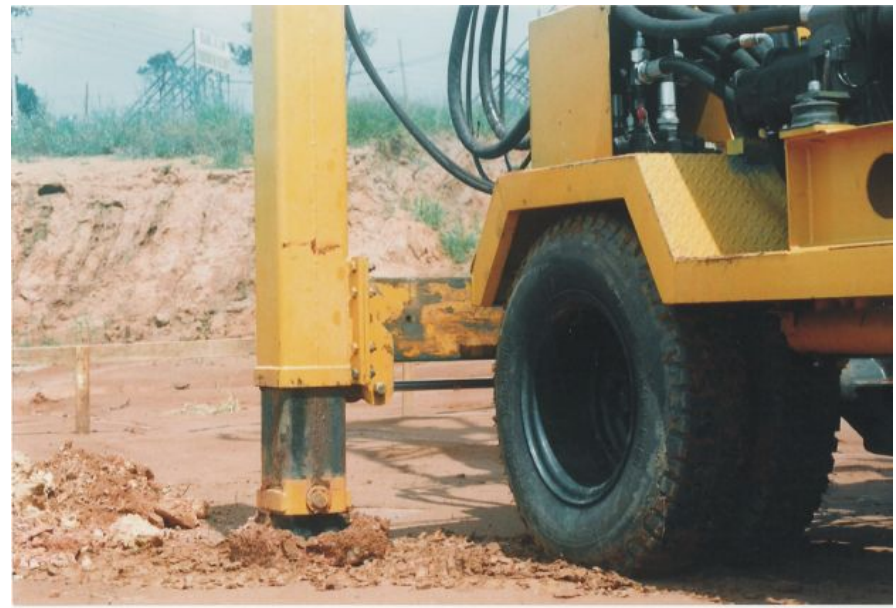

Figura 3.10 - Detalhe de um cilindro de nivelamento e autocarregamento.

Os quatro cilindros hidráulicos verticais fixados à estrutura da plataforma tem as seguintes funções:

a) Possibilitar o nivelamento do equipamento para o início da operação de escavação da estaca ou tubulão (Figuras 3.9 e 3.10).

b) Possibilitar o autocarregamento do equipamento (Figura 3.11). 


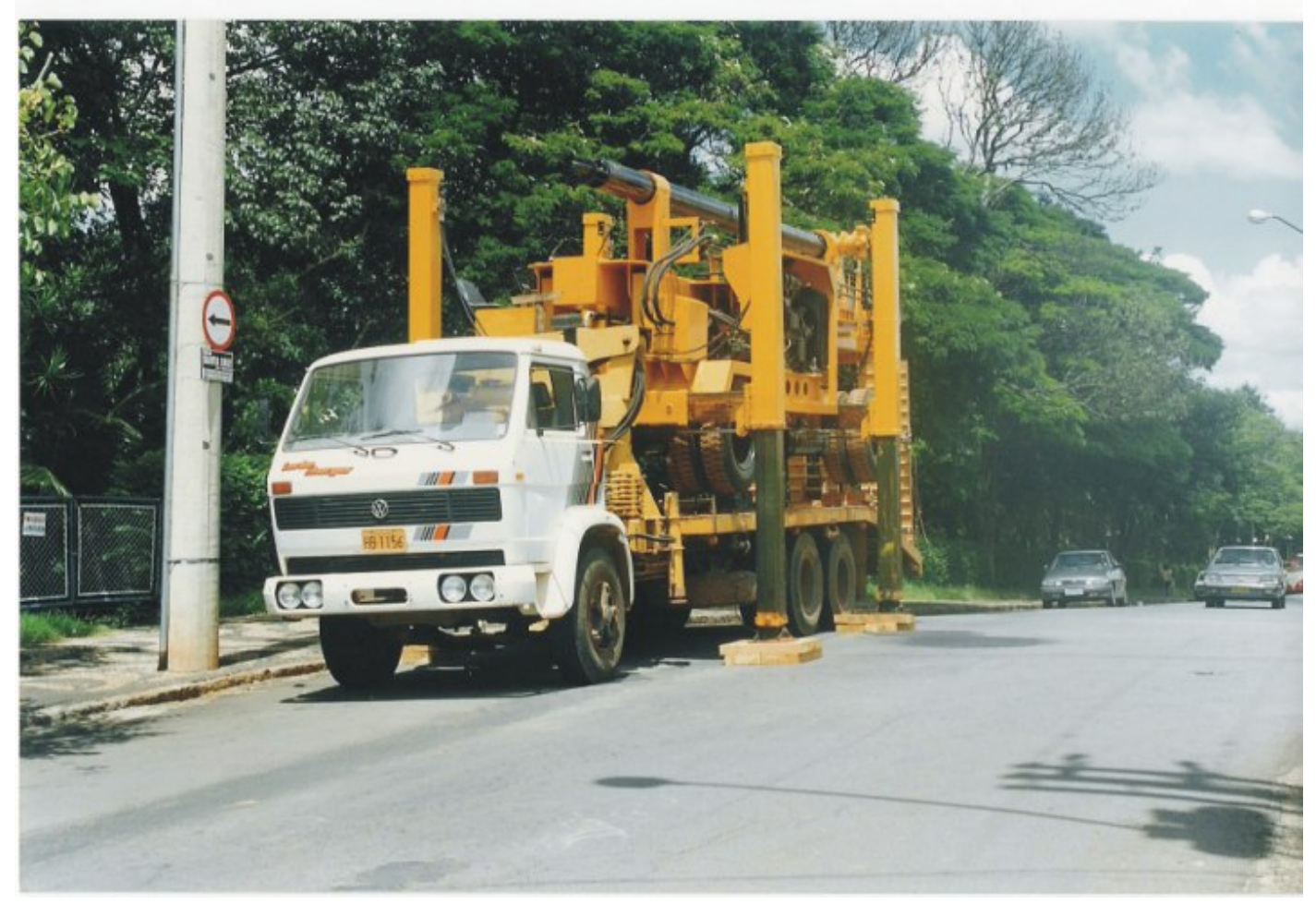

Figura 3.11 - Vista da perfuratriz durante a operação de autocarregamento.

c) Elevar um dos quatro pontos de apoio (pneus) para colocação de pranchas de madeira com o objetivo de facilitar as manobras na obra, em condições de muita lama e/ou solos superficiais de baixa resistência.

d) Elevar o sistema de direção e mesa compensadora de nível para possibilitar o giro desse conjunto que quando abaixado ocupa nova posição que com o acionamento dos cilindros da direção, ocorre um movimento circular (giro) da frente do equipamento, facilitando o posicionamento do trado sobre a estaca a ser escavada.

Os cilindros horizontais, também chamados de cilindros expansores, são cilindros de dimensões reduzidas que tem a finalidade de expandir, no plano horizontal, os cilindros de patolamento e autocarregamento. Essa expansão promove o aumento da distância entre centros das hastes dos cilindros de patolamento, medida no plano horizontal, o que aumenta a estabilidade do equipamento na obra e possibilita o seu autocarregamento.

Na Figura 3.12 dois cilindros expansores podem ser vistos sob o chassi do equipamento, na posição de haste estendida, para a operação de autocarregamento. 


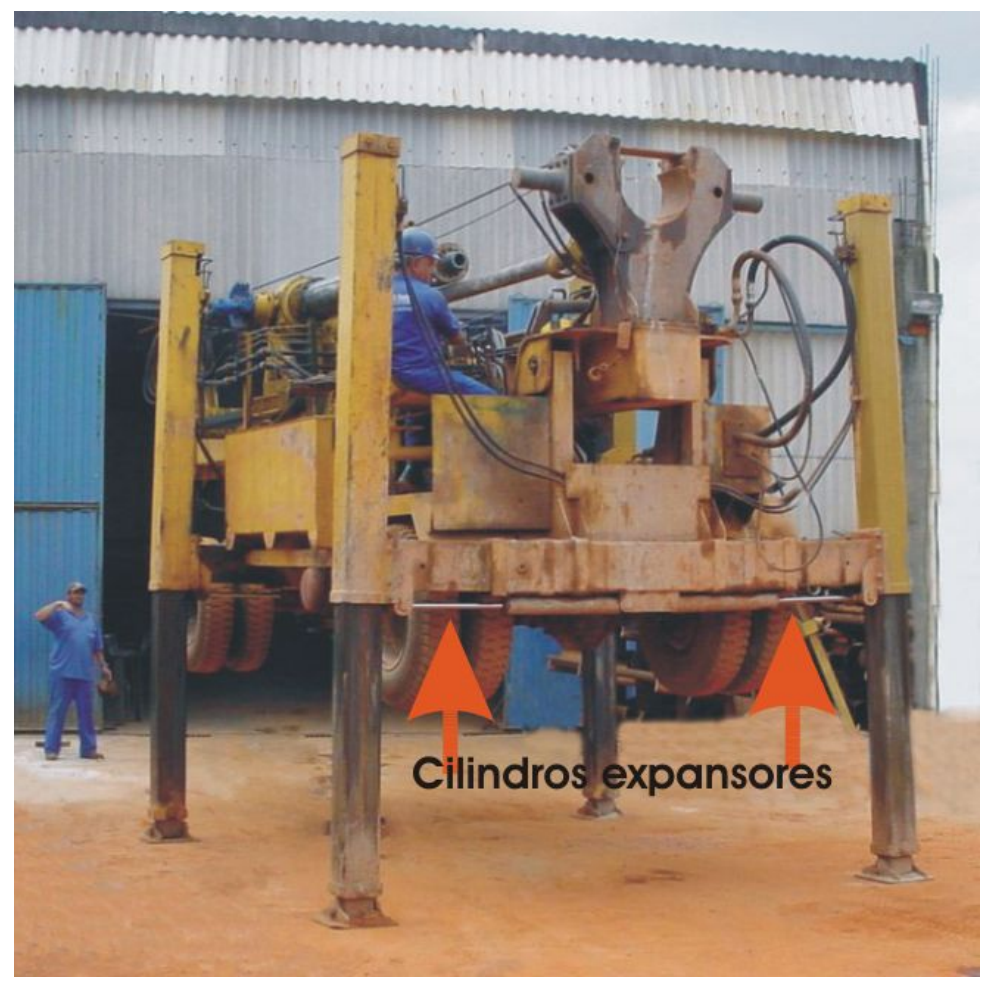

Figura 3.12 - Cilindros expansores.

\subsubsection{UNIDADE DE FORÇA}

A perfuratriz utiliza uma única fonte de energia. Utilizou-se um motor a diesel, turbo aspirado, marca MWM, modelo TD 229-EC-6, com potência nominal de 127 CV a 1800 rpm que é responsável pelo funcionamento de todos os mecanismos do equipamento. A Figura 3.13 mostra a geometria dos motores estacionários fabricados pela empresa MWM e a Tabela 3.1 fornece as dimensões principais de vários modelos.

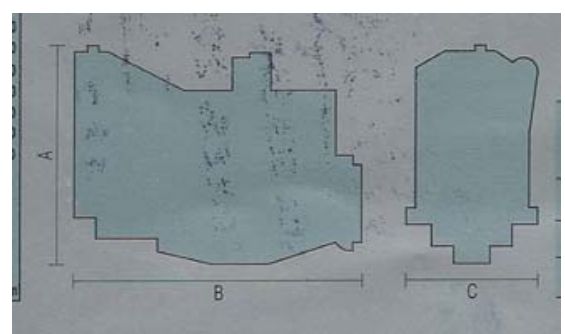

Tabela 3.1 - Dimensões principais dos motores MWM. (MWM, 1993).

\begin{tabular}{c|l|l|l|l|}
\hline \multirow{2}{*}{$\begin{array}{c}\text { DIMENSŌES } \\
(\mathrm{mm})\end{array}$} & \multicolumn{4}{|c}{ MODELO DO MOTOR } \\
\cline { 2 - 5 } & D 229-3 & D 229-4 & D 229-6 & TD 229-EC-6 \\
\hline A & 907 & 938 & 1059 & 1134 \\
\hline B & 964 & 1092 & 1351 & 1420 \\
\hline C & 680 & 680 & 680 & 680 \\
\hline
\end{tabular}

Figura 3.13 - Geometria dos motores MWM (MWM, 1993).

O modelo utilizado (TD 229-EC-6) teve a bomba injetora de combustível calibrada para rendimento máximo a 1800 rpm (Figura 3.14). Nesta condição ele fornece 92 kW(125 CV) que é a máxima potência contínua. Quando o motor é solicitado acima da potência máxima, a rotação cai e a potência máxima bloqueada atinge o pico de 101 
kW(137CV). Para operação em regime contínuo na potência máxima o consumo de combustível é de 224 g/kWh.

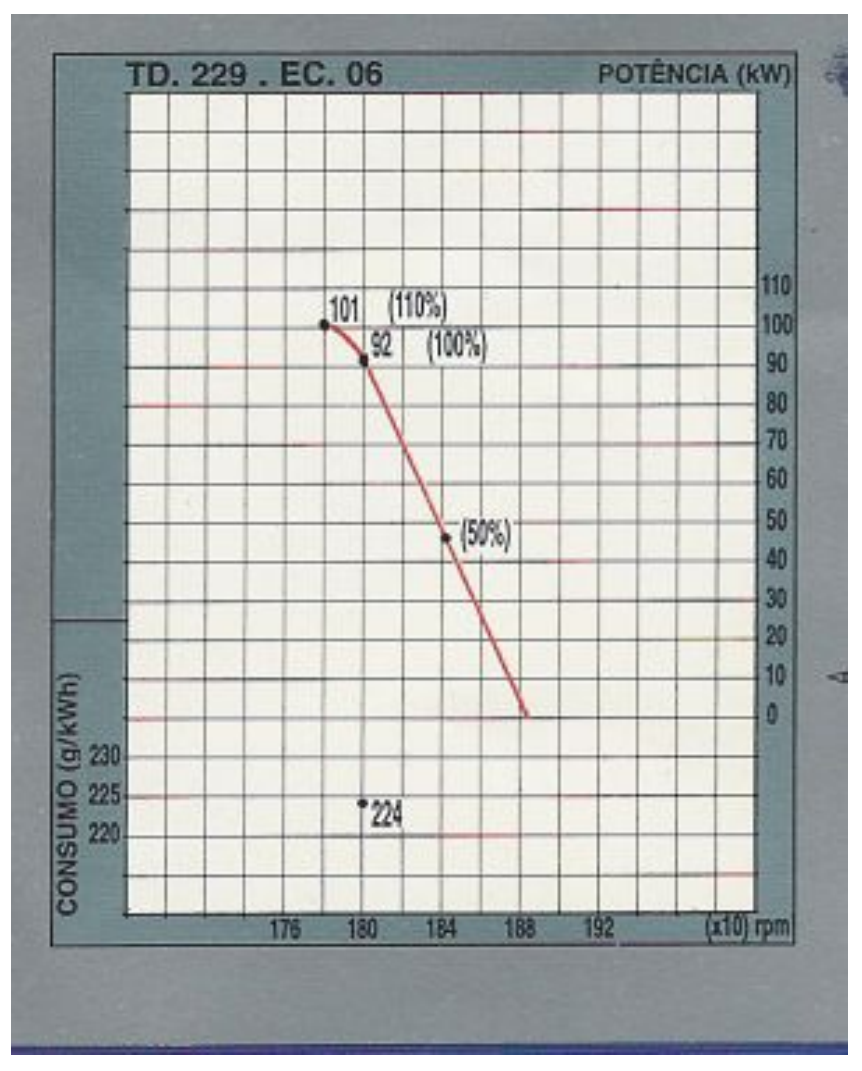

Uma bomba tripla de engrenagens é acoplada ao eixo de saída da unidade de força, para transformar energia mecânica em energia hidráulica.

Durante as manobras do equipamento pode-se utilizar rotações menores que a nominal de trabalho (1800 rpm), já que essas operações podem ou às vezes até necessitam ser mais lentas. Pode-se citar as seguintes situações onde tal fato normalmente ocorre: articulação da torre para as diversas posições desde a horizontal até a

Figura 3.14 - Curva de desempenho do motor MWM modelo TD229-EC-6 (MWM, 1993).

vertical, movimentação do equipamento em terrenos com declividade acentuada, utilização da direção hidráulica em espaços reduzidos, utilização do sistema de nivelamento. Nesses casos as duas bombas principais trabalham apenas circulando o óleo hidráulico pelo sistema, e portanto, a pressão hidráulica é apenas aquela necessária para vencer as perdas de carga responsável pelo transporte do óleo hidráulico ao corpo de admissão do comando auxiliar, trabalha com vazões abaixo da vazão máxima de projeto, já que a rotação também é menor que a nominal. Dessa forma a energia consumida nessas manobra é baixa o que resulta em baixo consumo de combustível.

A Figura 3.15 mostra o motor MWM modelo TD229-EC-6 instalado na plataforma da perfuratriz. Pode-se observar a bomba hidráulica acoplada à unidade motriz. 


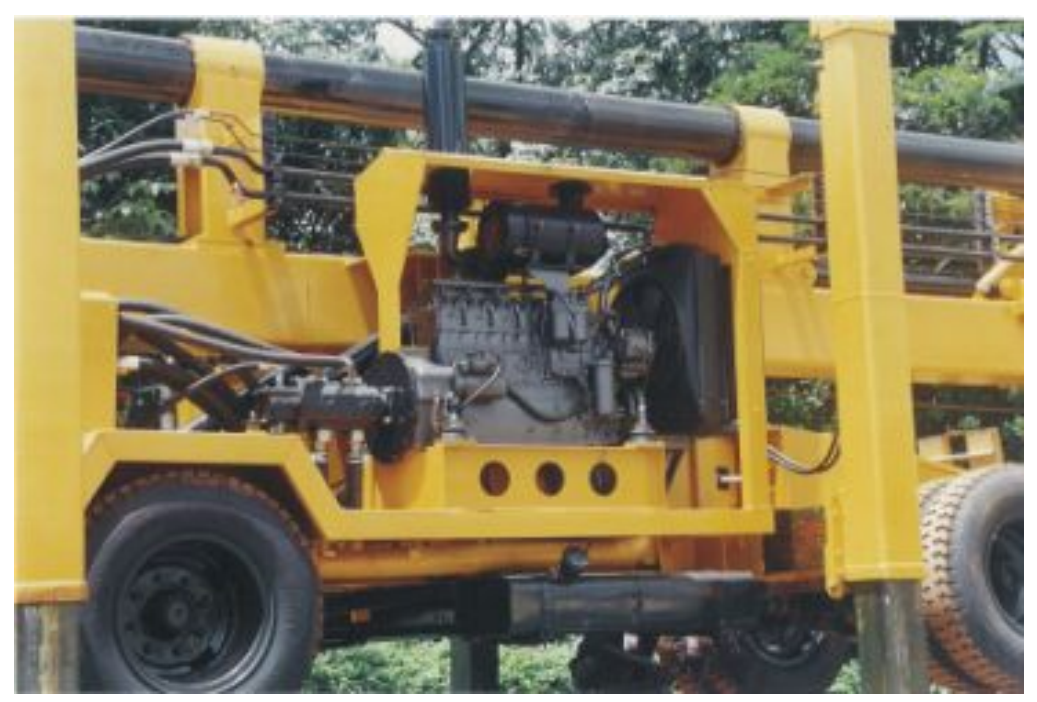

Figura 3.15 - Unidade de força instalada na plataforma.

\subsubsection{TORRE}

A torre da perfuratriz possui seção transversal quadrada, vazada, formada pela união, através de solda elétrica do tipo MIG, de dois perfis em “U”. É articulada em um suporte que fica fixo à plataforma do equipamento. Dois cilindros hidráulicos são utilizados para formar o segundo ponto de apoio e possibilitar o movimento de giro da torre que a coloca desde a posição horizontal, que é uma posição de manobra ou de transporte, até a posição vertical que é a posição de trabalho.

Para a execução de estacas "hélice segmentada”, os seguintes conjuntos são instalados na torre:

a) Mesa rotativa, também conhecida como cabeçote de perfuração.

b) Cilindro de empuxo axial (pull-down e pull-back).

c) Conjunto roldanas e suporte das roldanas.

d) Guincho auxiliar.

e) Conjunto alimentador de trados.

f) Trados segmentados.

g) Haste telescópica de dois elementos.

h) Morsa hidráulica.

Para a execução de estacas escavadas ou tubulões, alguns conjuntos são retirados e outros são instalados. São retirados os seguintes conjuntos: 
a) Conjunto alimentador de trados.

b) Trados segmentados.

c) Haste telescópica de dois elementos.

d) Morsa hidráulica.

E os seguintes conjuntos são instalados:

a) Haste telescópica de cinco elementos.

b) Trado curto.

A Figura 3.16 mostra a torre e os conjuntos que são montados sobre ela.

A morsa é montada na parte inferior da torre ao passo que o conjunto das roldanas fica na parte superior da mesma. Um segmento de hélice de $3500 \mathrm{~mm}$ fica sempre alinhado com o sistema de injeção (swivel), com a haste de prolongamento e com o eixo de saída do cabeçote rotativo. Três segmentos ficam no alimentador e são acoplados um sobre o outro na medida em que a estaca vai sendo escavada. Um segmento de $1500 \mathrm{~mm}$ é utilizado em conjunto com o segmento que permanece sempre na posição de trabalho para total aproveitamento do curso do cilindro de empuxo axial.
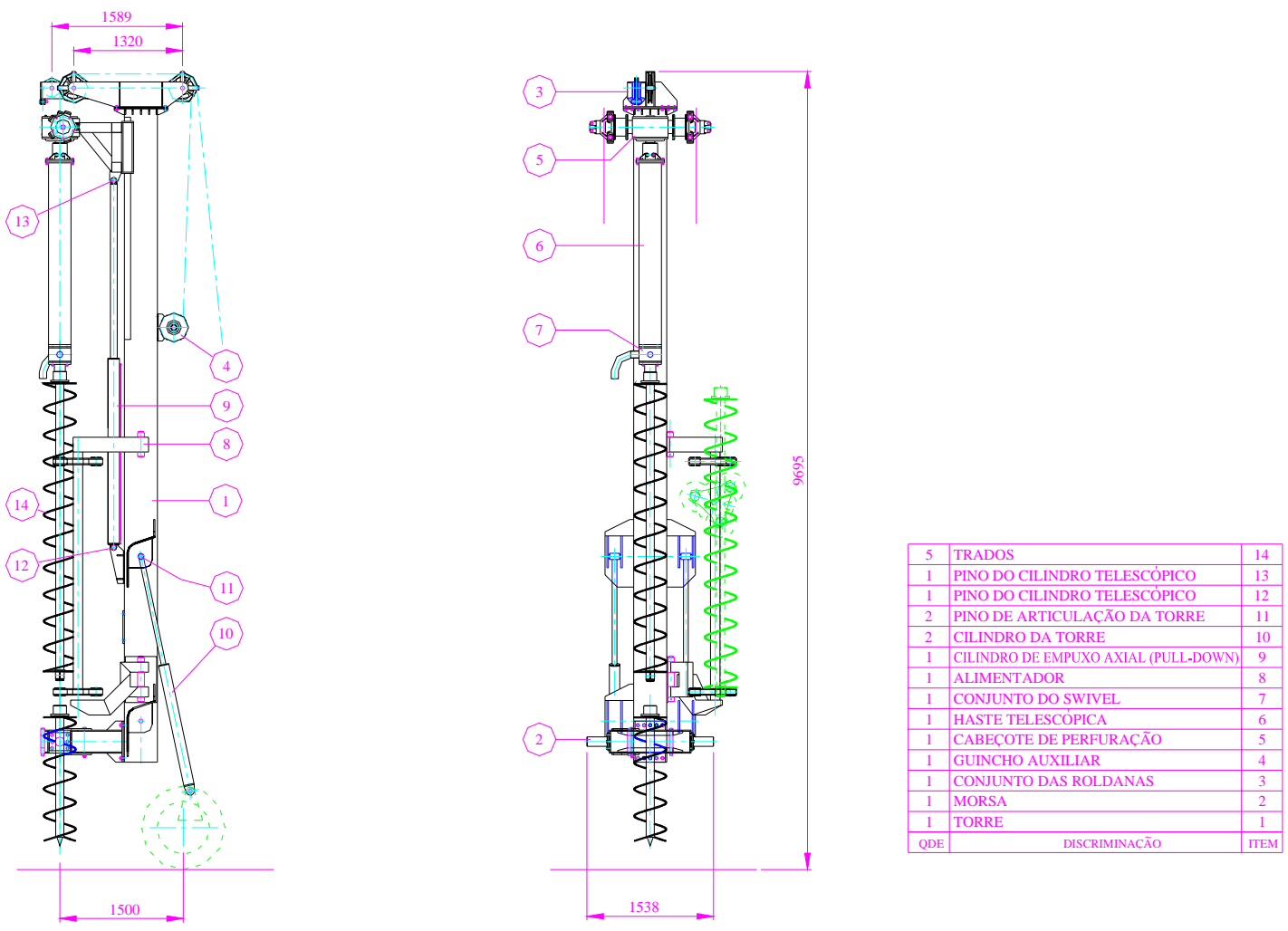

Figura 3.16 - Montagem dos conjuntos sobre a torre 
A operação de troca de conjuntos para possibilitar o uso multifunção do equipamento ocupa aproximadamente 1 dia de trabalho de 2 funcionários, que corresponde a aproximadamente 18 horas de um oficial em montagem mecânica. É comum nas empresas metalurgicas a utilização da unidade "homem hora" designada por "hh", embora ela não exista no sistema internacional de medidas.

A Figura 3.17 apresenta uma vista da torre sendo colocada na posição horizontal, para efetuar as manobras necessárias à execução do próximo tubulão. Nessa figura pode-se observar que está sendo utilizado um trado curto para a execução de estacas ou tubulões e um conjunto de hastes telescópicas longo. Como já foi mencionado esse conjunto de hastes telescópicas é formado por cinco elementos. A Figura 3.18 mostra o equipamento com a torre na posição vertical para a execução de uma estaca hélice segmentada.

Para a execução de estaca hélice segmentada utiliza-se uma haste telescópica mais curta, de dois elementos.

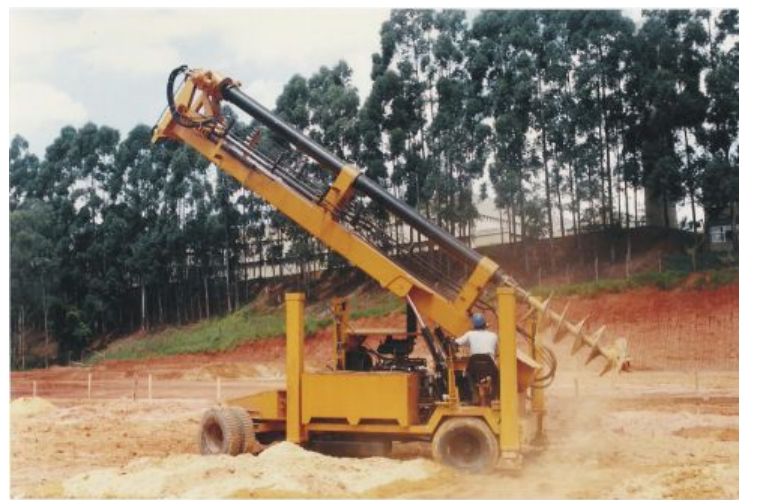

Figura 3.17 - Vista da torre com haste para estacas escavadas e tubulões.

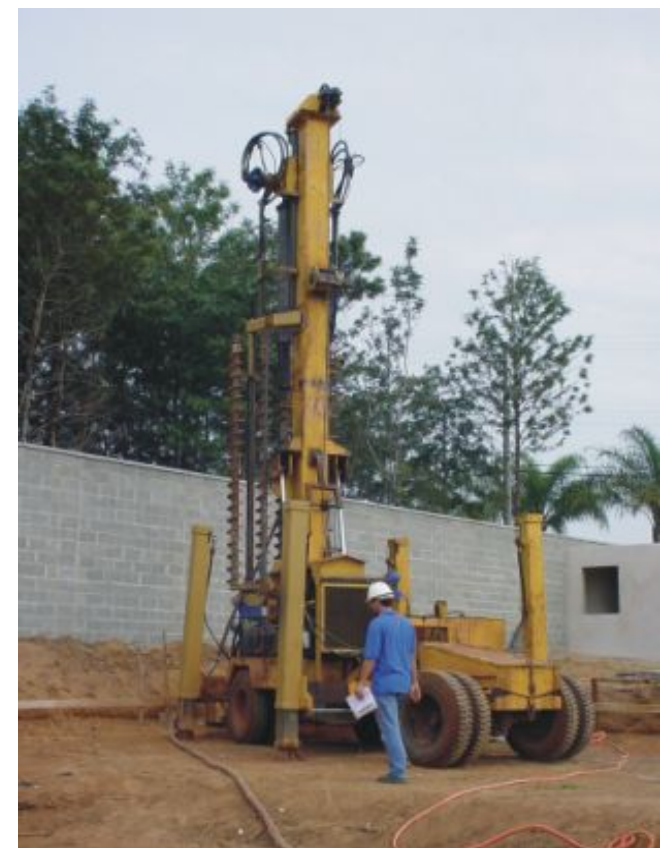

Figura 3.18 - Torre na posição de trabalho com montagem para estaca hélice segmentada

A Figura 3.19 apresenta uma vista geral da perfuratriz na qual pode ser vista a haste telescópica e a Figura 3.20 fornece uma vista em detalhe dessa mesma haste, também conhecida como haste de prolongamento ou prolonga.

No item 3.3.13 do presente capítulo, as hastes telescópicas serão abordadas mais detalhadamente. 


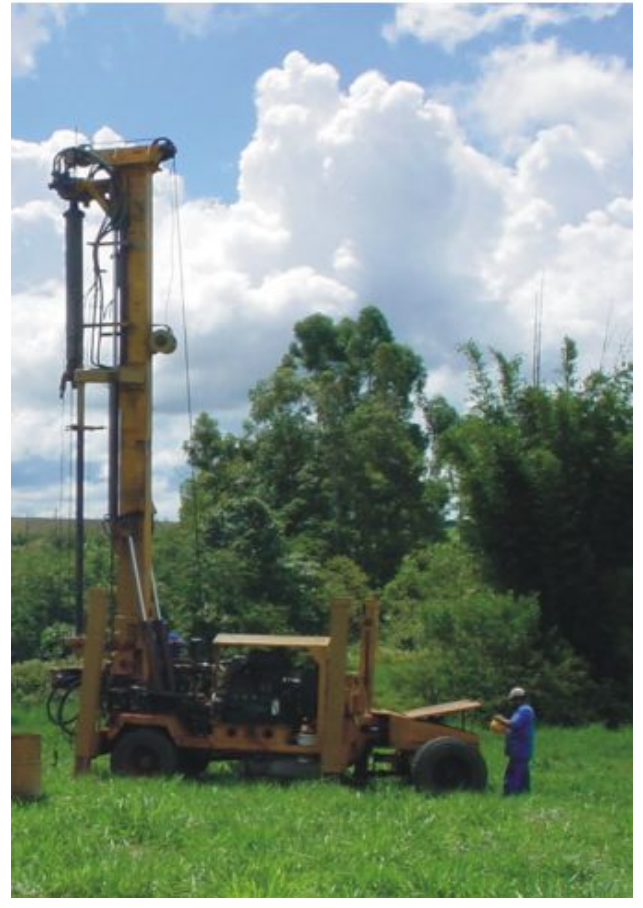

Figura 3.19 - vista geral da perfuratriz

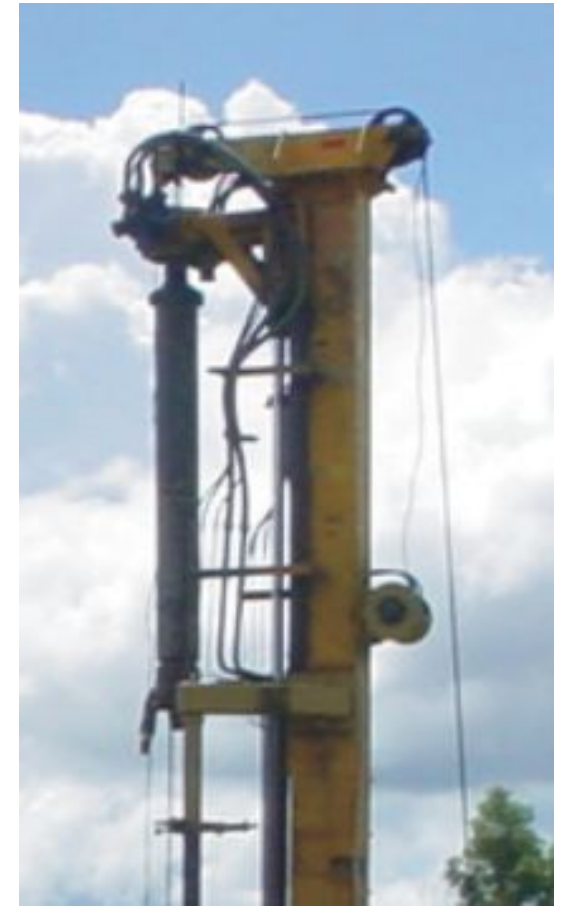

Figura 3.20 - Detalhe da prolonga

\subsubsection{CABEÇOTE ROTATIVO}

Este conjunto é também conhecido como mesa rotativa ou ainda cabeçote de perfuração. É constituido basicamente por uma carcaça metálica em cujo interior são montadas as engrenagens que formam um redutor de velocidade. No presente trabalho optou-se pela utilização de dois motores hidráulicos de pistões radiais de duplo deslocamento volumétrico (dupla cilindrada) que possibilita o trabalho com duas rotações no eixo de entrada do cabeçote rotativo. A transmissão do movimento é feita da seguinte forma:

Quando uma alavanca do comando hidráulico do cabeçote é acionada o óleo que vem da bomba hidráulica passa por esse comando e entra nos motores hidráulicos, provocando a rotação de seus eixos que estão acoplados aos eixos de entrada do cabeçote rotativo. Na outra extremidade de cada árvore de entrada existe uma engrenagem cônica (pinhão) que transmite o movimento a outra engrenagem maior denominada coroa que é fixada ao eixo de saída da mesa rotativa. Esse eixo de saída recebe um acoplamento que faz a ligação com a hélice segmentada.

Os motores hidráulicos são ligados por mangueiras e conexões hidráulicas, em paralelo, e fornecem aproximadamente $28 \mathrm{rpm}$ quando o comando da primeira bomba é acionado, 56 rpm quando duas bombas são utilizadas em conjunto e $112 \mathrm{rpm}$ quando um comando hidráulico de pilotagem dos motores hidráulicos é acionado. A pilotagem 
acontece basicamente da seguinte maneira: Quando a válvula direcional (válvula de comando) de pilotagem é acionada o óleo hidráulico pressuriza um cilindro interno do motor hidráulico responsável pela mudança de cilindrada do mesmo. Essa mudança de deslocamento volumétrico provoca a mudança da rotação do motor. A Figura 3.21 mostra um desenho esquemático do cabeçote rotativo.
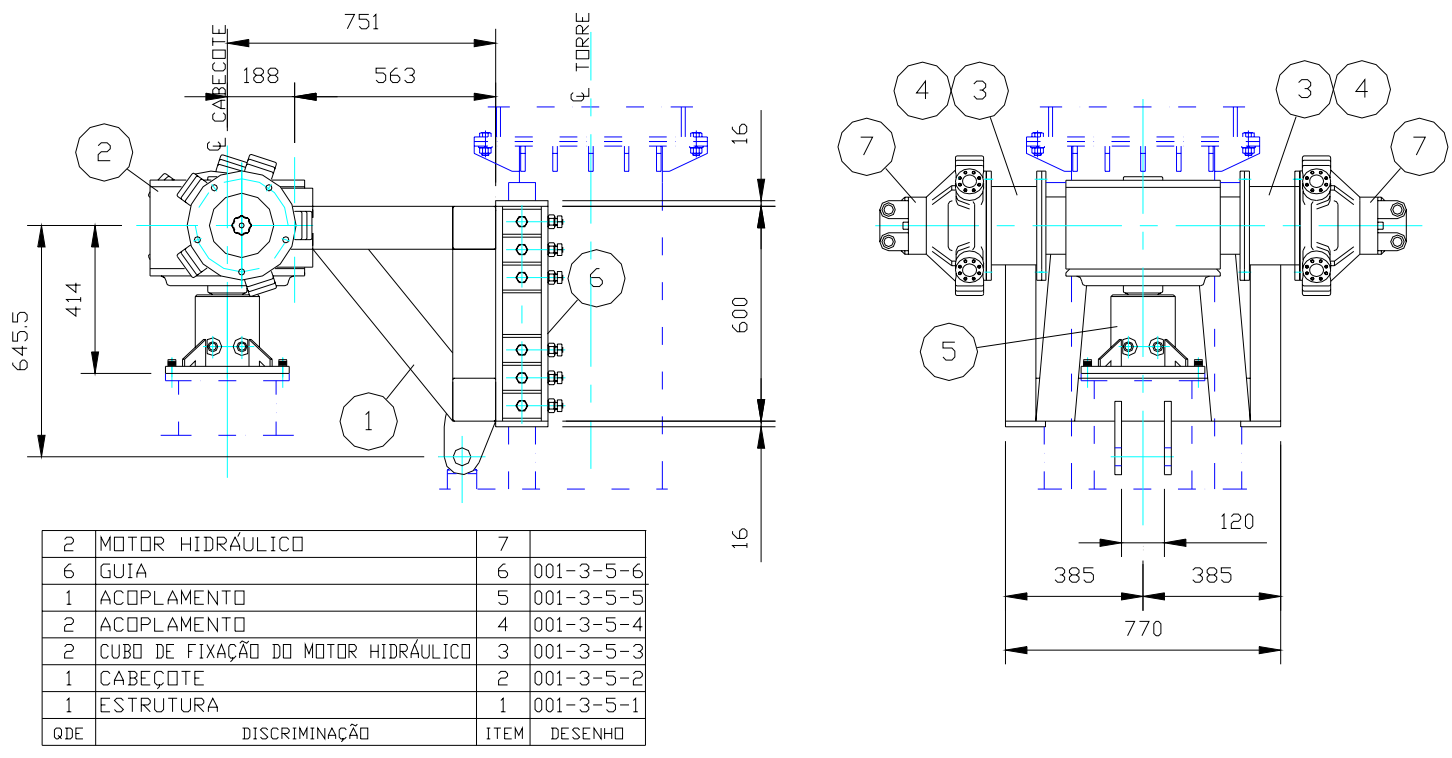

Figura 3.21 - Esquema do cabeçote rotativo.

Na Figura 3.22 pode-se ver o cabeçote rotativo instalado na torre, a qual encontra-se na posição horizontal, também chamada de posição de transporte. Como a vista é lateral, vê-se apenas um dos motores hidráulicos. Nessa posição o cilindro de empuxo axial (pull-down e pull-back) encontra-se com a haste recolhida.

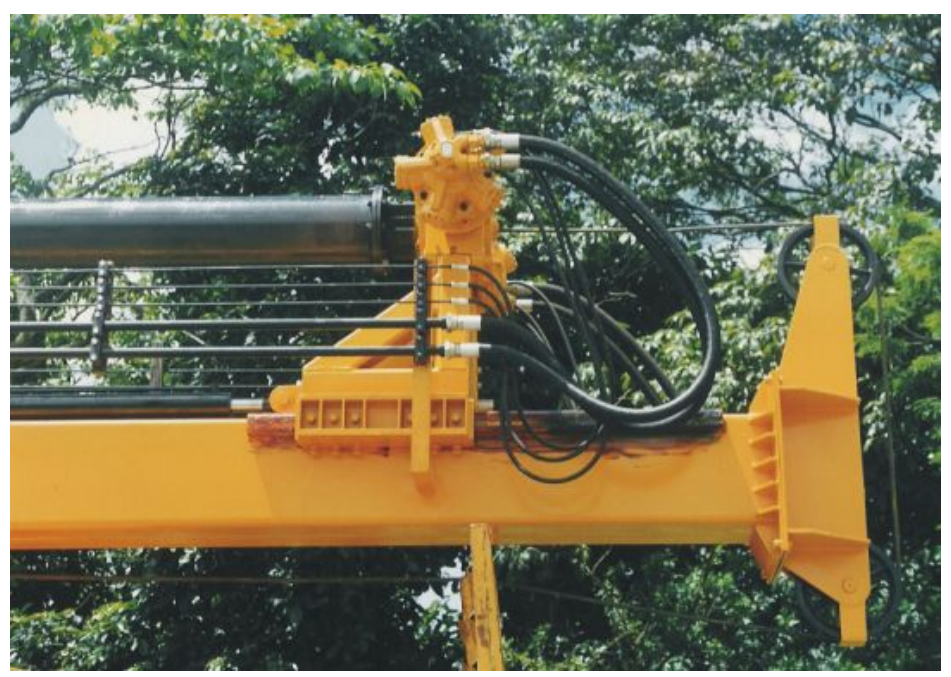

Figura3.22 - Vista do cabeçote rotativo. 


\subsubsection{GUINCHO PRINCIPAL}

É constituído por uma estrutura metálica na qual são montados o redutor e o tambor. Um motor hidráulico é acionado pelo óleo que vem de uma bomba hidráulica (bomba 02). A transmissão de movimento é semelhante à do cabeçote rotativo com a diferença que na árvore de saída é acoplado o tambor que tem a função de enrolar e desenrolar o cabo de aço que é fixado em um girador (swivel), o qual por sua vez é fixado por um pino à haste mais interna do conjunto de hastes telescópicas.

Utilizou-se o mesmo modelo de motor hidráulico do cabeçote rotativo, com o objetivo de maximizar a padronização de componentes comerciais.

A Figura 3.23 apresenta um desenho simplificado desse conjunto.
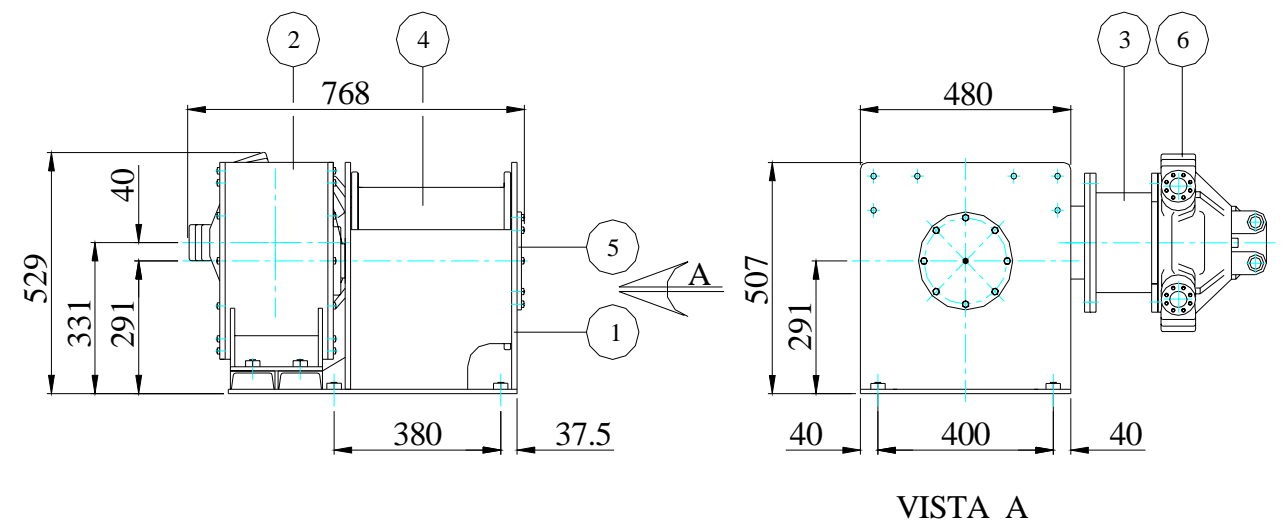

\begin{tabular}{|c|l|r|l|}
\hline 1 & MOTOR HIDRÁULICO & 6 & \\
\hline 1 & CONJUNTO DE MANCAL & 5 & $001-1-4-5$ \\
\hline 1 & TAMBOR & 4 & $001-1-4-4$ \\
\hline 1 & CUBO DE FIXAÇÃO DO MOTOR HID. & 3 & $001-1-4-3$ \\
\hline 1 & CONJUNTO DE REDUTOR & 2 & $001-1-4-2$ \\
\hline 1 & SUPORTE & 1 & $001-1-4-1$ \\
\hline QDE & ITEM & DESENHO \\
\hline
\end{tabular}

Figura 3.23 - Guincho principal

\subsubsection{GUINCHO AUXILIAR}

Projetou-se este guincho para o auxílio nas manobras tais como: retirada e instalação de segmentos de hélices no alimentador, colocação de armaduras nas estacas, auxílio na movimentação de mangueira da bomba de argamassa e outros serviços auxiliares de movimentação de cargas leves, eventualmente necessários.

O guincho auxiliar é dispensável para o funcionamento do equipamento e portanto é um conjunto opcional, porém, facilita consideravelmente o trabalho na obra (Figura 3.24). 

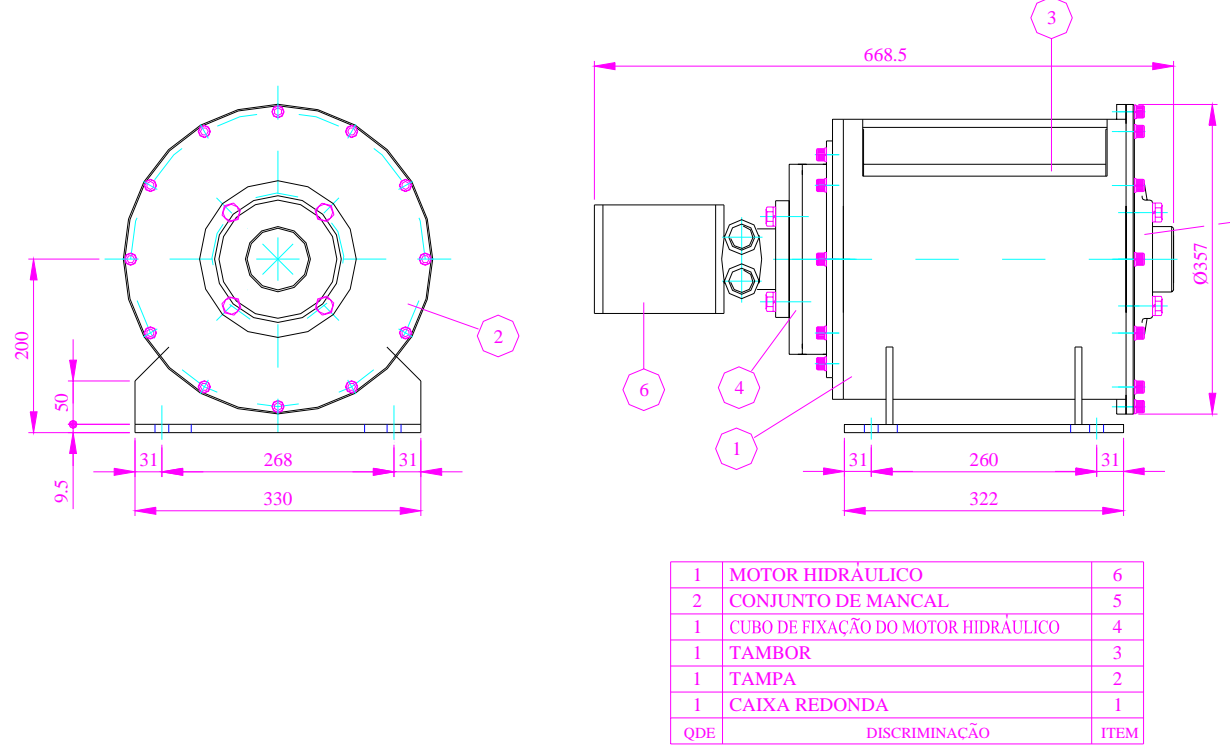

Figura 3.24 - Guincho auxiliar.

\subsubsection{CILINDRO DE EMPUXO AXIAL}

Os cilindros hidráulicos são atuadores lineares, uma vez que, as forças atuantes no sistema provocam movimentos retilíneos. Eles transformam energia hidráulica em energia mecânica. São normalmente aplicados em prensas, injetoras, perfuratrizes para solos e rochas, extrusoras, máquinas operatrizes em geral, guindastes escavadeiras e muitos outros equipamentos.

Basicamente, os cilindros podem ser de simples ação ou de dupla ação. O cilindro de simples ação permite o movimento por pressão hidráulica em apenas um sentido sendo que o retorno à posição anterior ao movimento pode ser feita por qualquer outro agente (mola, gravidade) que não o fluido hidráulico (Figura 3.25). No cilindro de dupla ação o movimento da haste é permitido em dois sentidos através da entrada do óleo hidráulico em qualquer um dos pórticos que ora funcionam como entrada e ora como saída do óleo (Figura 3.26).

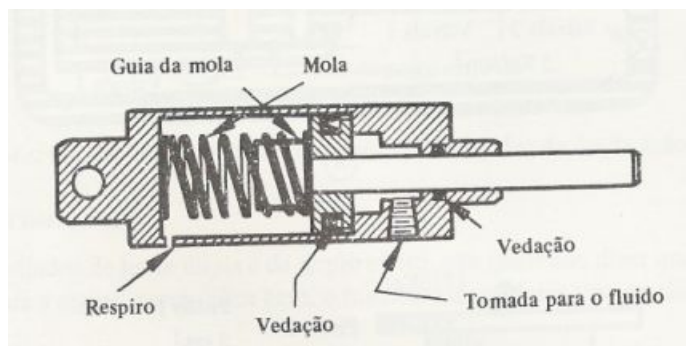

Figura 3.25 - Cilindro de simples efeito com retorno por mola (Palmieri, 1985).

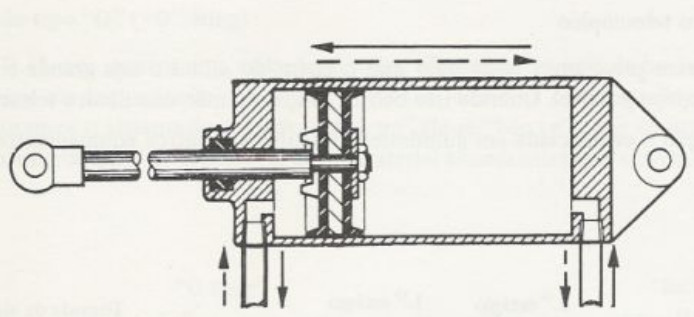

Figura 3.26 - Cilindro de duplo efeito (Palmieri, 1985). 
Palmieri (1985) também apresenta esquemas de algumas formas de aplicação dos cilindros hidráulicos (Figura 3.27).

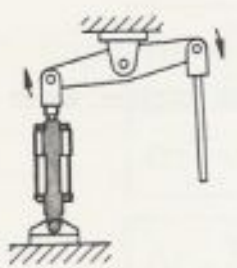

Alavanca

$10^{\circ}$ tipo

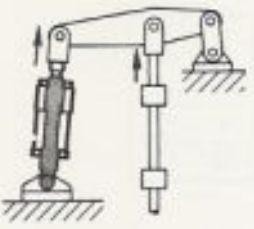

Redutor de trancos

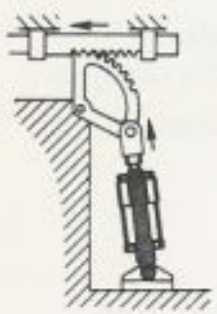

Movimento horizontal paralélo

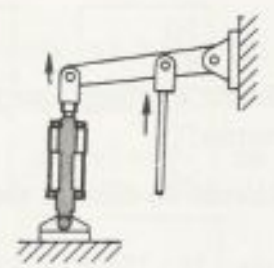

Alavanca 2. ${ }^{\circ}$ tipo
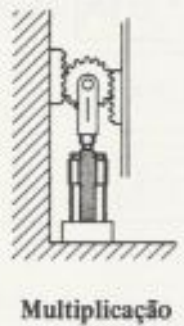
de velocidade

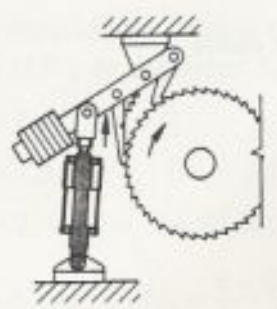

Movimento rotativo, praticamente contínuo

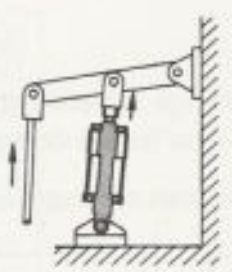

Alavanca

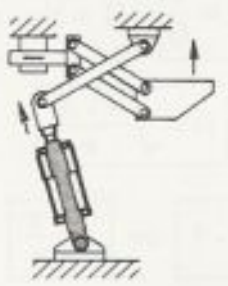

Movimento retilíneo em duas direçōes

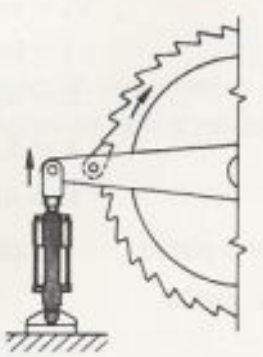

Catraca

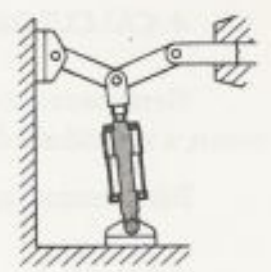

Joetho

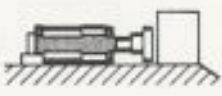

Empurrar ou puxar

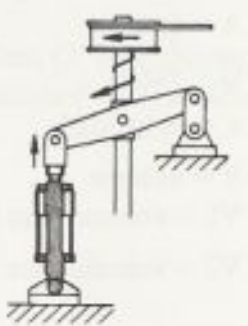

Movimento rotativo rápido, usando "sem-fins"
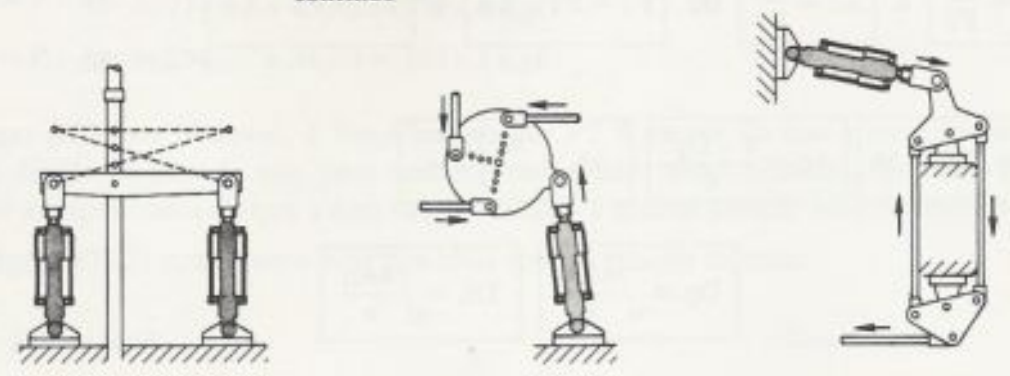

Quatro posiçōes

Taramela

Movimento transferido para um dois cilindros ponto distante

Figura 3.27 - Aplicações para cilindros (Palmieri, 1985). 
Um cilindro pode ter haste simples (Figura 3.28) ou haste dupla (Figura 3.29), ou ainda, hastes telescópicas (Figura 3.30).

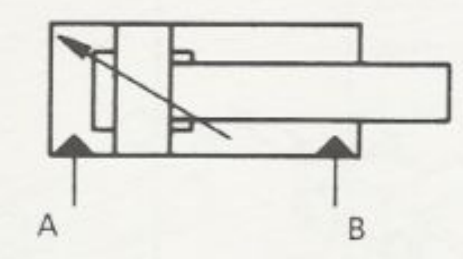

Figura 3.28 - Cilindro de haste simples e dupla ação (REXROTH, 1988).

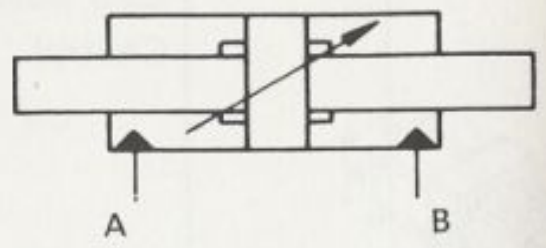

Figura 3.29 - Cilindro de haste dupla (REXROTH, 1985).

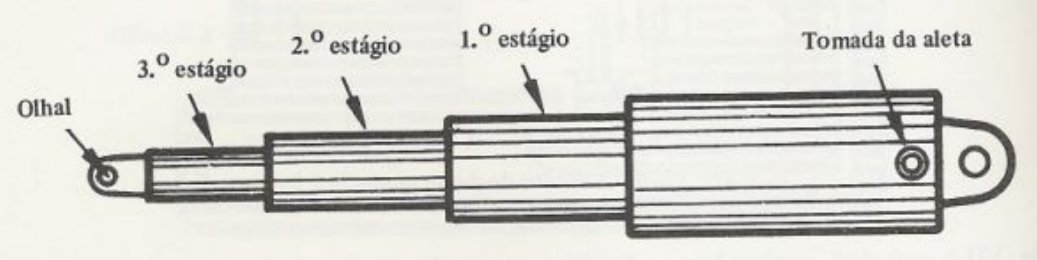

Figura 3.30 - Cilindro com hastes telescópicas (Palmieri, 1985).

No presente trabalho, para as operações de avanço (pull-down) e extração (pull-back) da hélice, utilizou-se um cilindro hidráulico de haste simples e dupla ação (Figura 3.31).

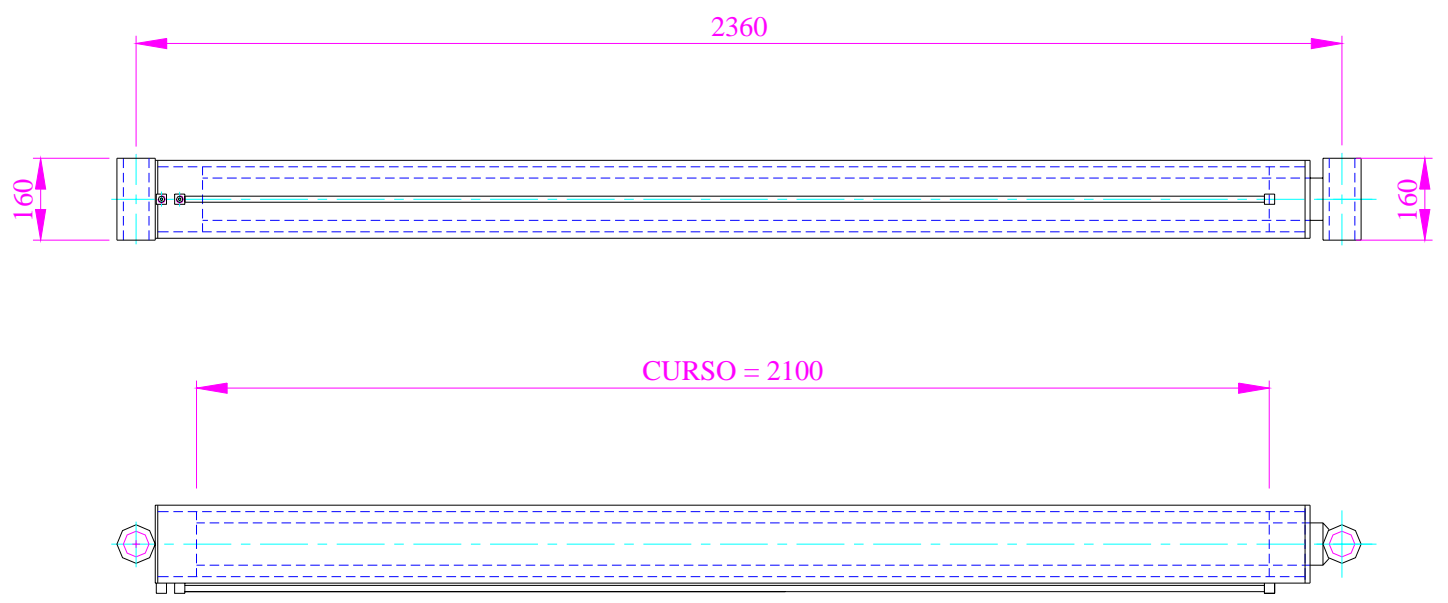

\begin{tabular}{|c|c|c|}
\hline 1 & CILINDRO DE EMPUXO AXIAL (PULL-DOWN) & 1 \\
\hline QDE & DISCRIMINAÇÃO & ITEM \\
\hline
\end{tabular}

Figura 3.31 - Cilindro de empuxo axial.

As Figuras 3.32 e 3.33 mostram o cilindro de empuxo axial montado na torre da perfuratriz com a haste para cima. Esta configuração de montagem resulta em esforços 
de extração da hélice (pull-back) maiores que os esforços de penetração (pull-down). Isto ocorre pelo fato de que para a penetração da hélice a pressão hidráulica é exercida em uma área que é igual a diferença entre a área da seção transversal da camisa do cilindro e a área da seção transversal da haste do mesmo, ao passo que para a operação de extração da hélice, a haste é extendida e, portanto, a pressão hidráulica é exercida sobre a seção transversal da camisa.

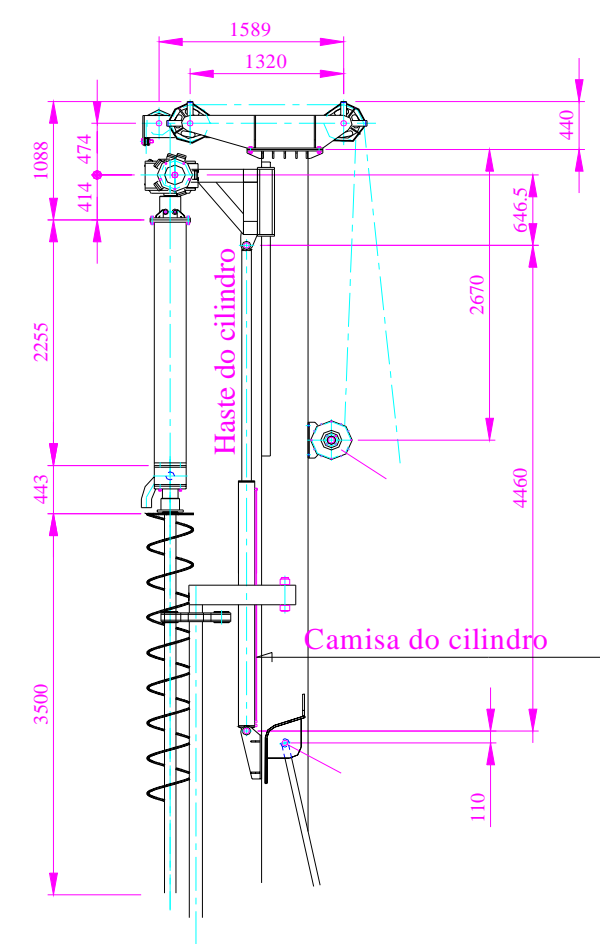

Figura 3.32 - Esquema de montagem do cilindro de empuxo axial.

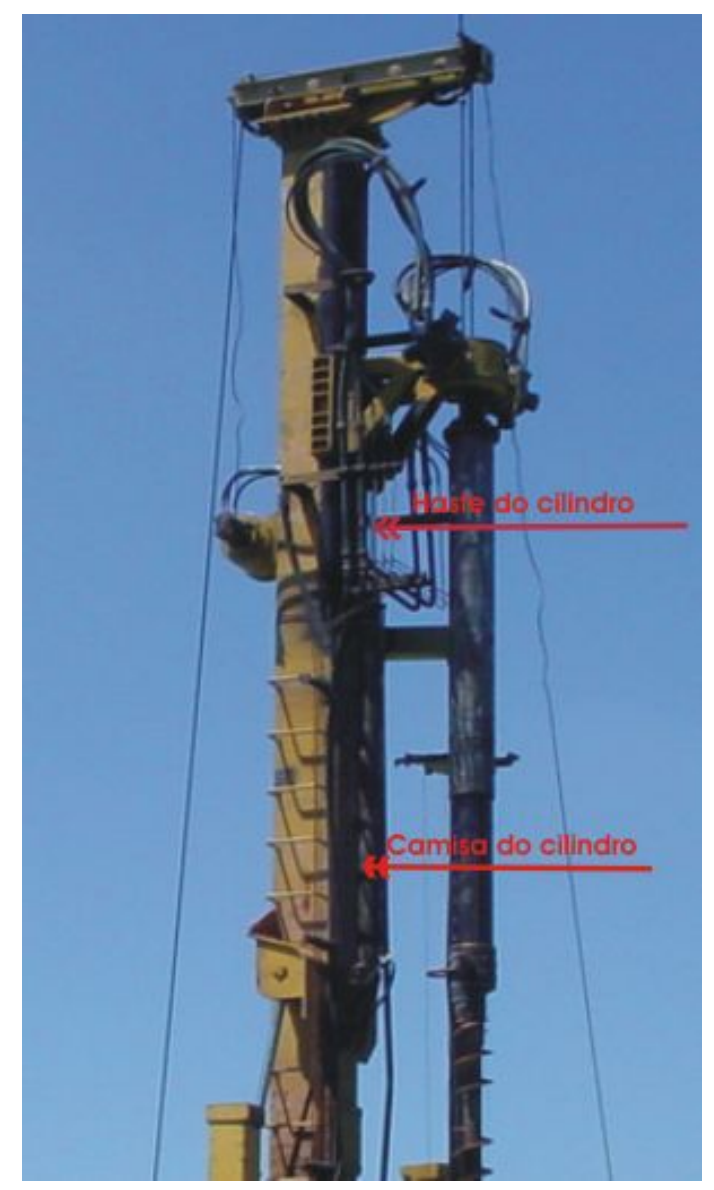

Figura 3.33 - Vista do cilindro de empuxo axial montado na torre.

Como pode ser observado nas Figura 3.32 e 3.33 o olhal da camisa é fixado na torre do equipamento enquanto que o olhal da haste é fixado no cabeçote rotativo.

\subsubsection{ALIMENTADOR DE HÉLICES SEGMENTADAS}

O conjunto alimentador de trados segmentados é basicamente constituído por uma estrutura metálica que se apoia na torre da perfuratriz através de duas articulações. Um 
movimento de rotação no plano horizontal é conseguido através do acionamento de um cilindro hidráulico, o que possibilita a instalação de um segmento sobre o outro. Até três segmentos de hélice podem ser colocados no alimentador.

A Figura 3.34 mostra um desenho do alimentador e na Figura 3.35 podem ser observados dois segmentos de hélice posicionados no alimentador durante uma operação de manobra da perfuratriz.
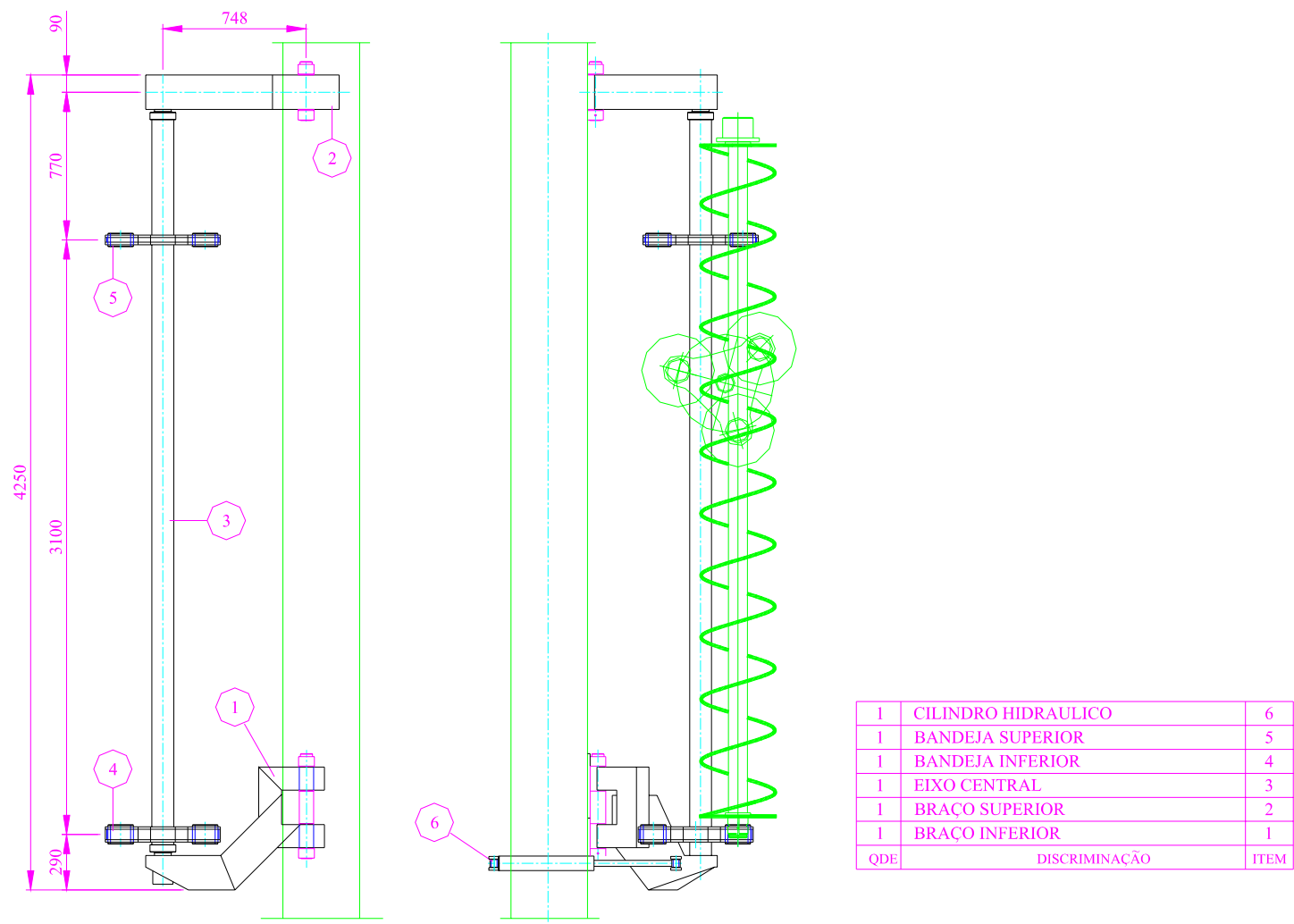

Figura 3.34 - Alimentador de trado segmentado.

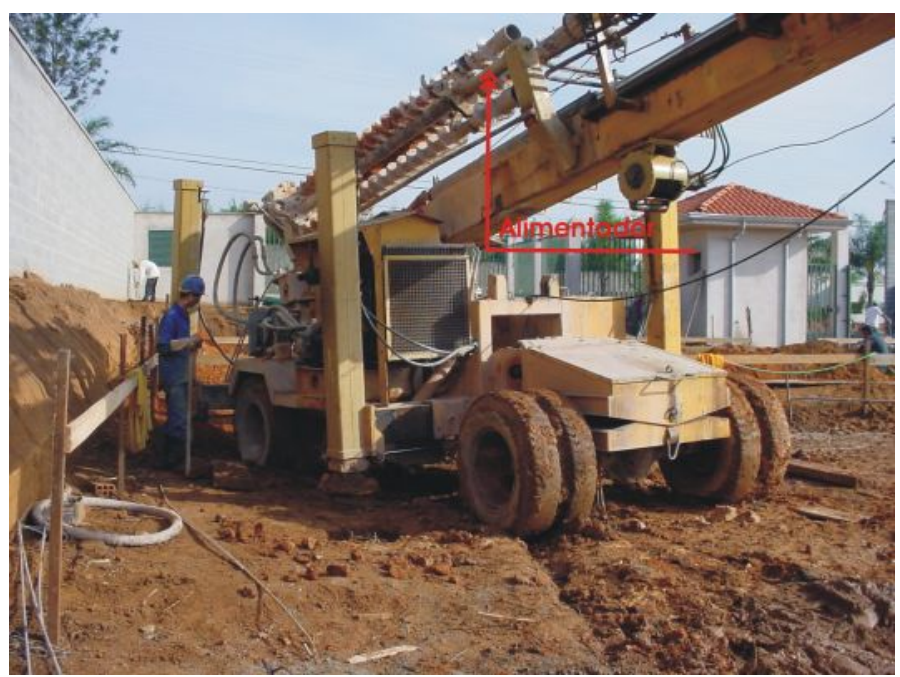

Figura 3.35 - Vista do alimentador de segmentos de hélice. 


\subsubsection{MORSA}

Este conjunto é formado por uma estrutura metálica e por dois cilindros hidráulicos que têm a função de fixar a composição da hélice durante as operações de instalação e de extração da hélice. A força de compressão dos cilindros contra o trado deve gerar forças de atrito capazes de impedir a rotação do mesmo no momento em que o cabeçote rotativo é acionado no sentido contrário ao da escavação, para soltar a rosca cônica do acoplamento que liga o cabeçote ao trado segmentado.

A Figura 3.36 mostra um desenho da morsa e a Figura 3.37 apresenta uma vista do mesmo conjunto, montado e fixado na torre.
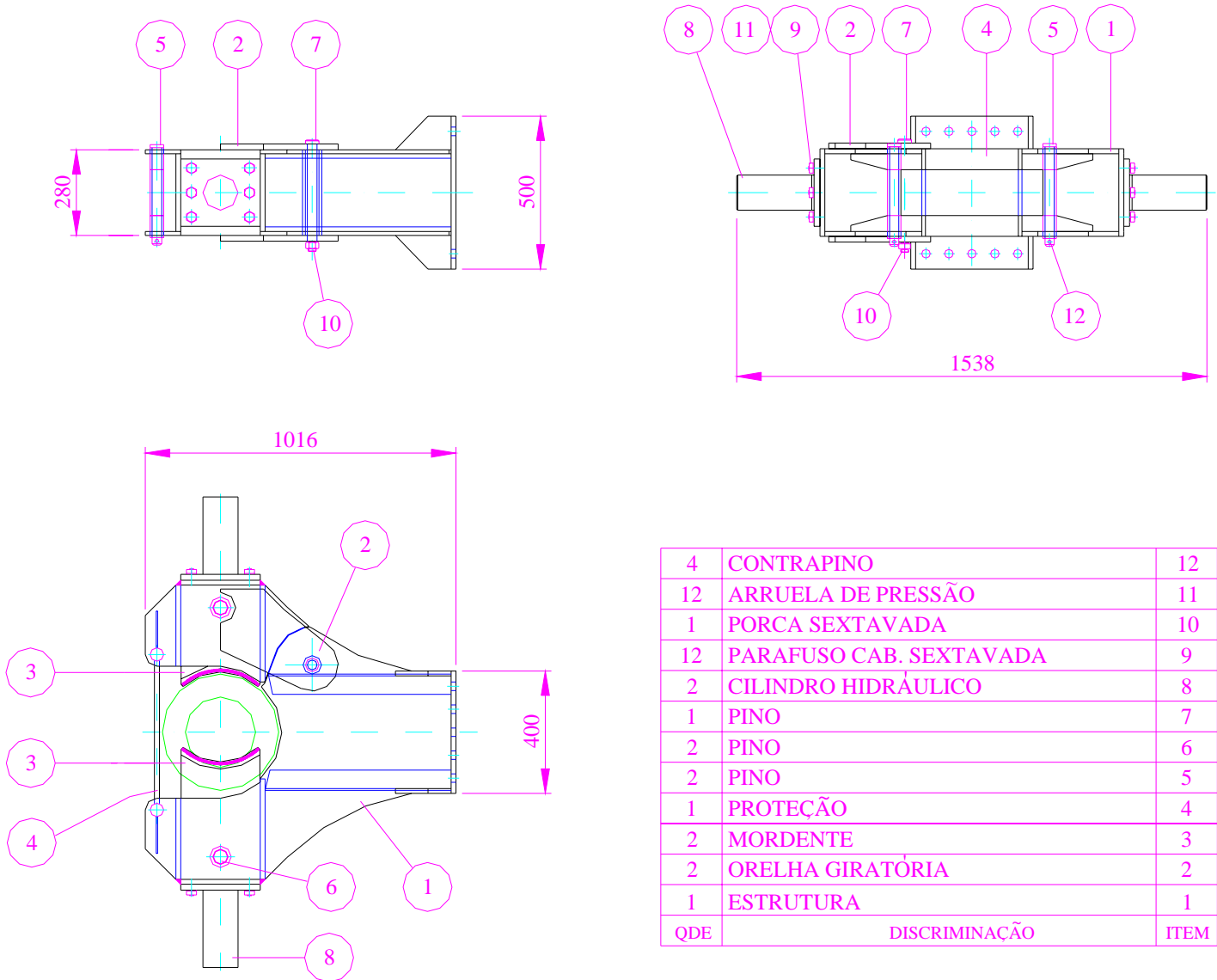

\begin{tabular}{|c|l|c|}
\hline 4 & CONTRAPINO & 12 \\
12 & ARRUELA DE PRESSÃO & 11 \\
\hline 1 & PORCA SEXTAVADA & 10 \\
12 & PARAFUSO CAB. SEXTAVADA & 9 \\
\hline 2 & CILINDRO HIDRÁULICO & 8 \\
\hline 1 & PINO & 7 \\
\hline 2 & PINO & 6 \\
\hline 2 & PINO & 5 \\
\hline 1 & PROTEÇÃO & 4 \\
\hline 2 & MORDENTE & 3 \\
\hline 2 & ORELHA GIRATÓRIA & 2 \\
\hline 1 & ESTRUTURA & 1 \\
\hline QDE & \multicolumn{2}{|c|}{ DISCRIMINAÇÃO } \\
\hline
\end{tabular}

Figura 3.36 - Morsa hidráulica. 


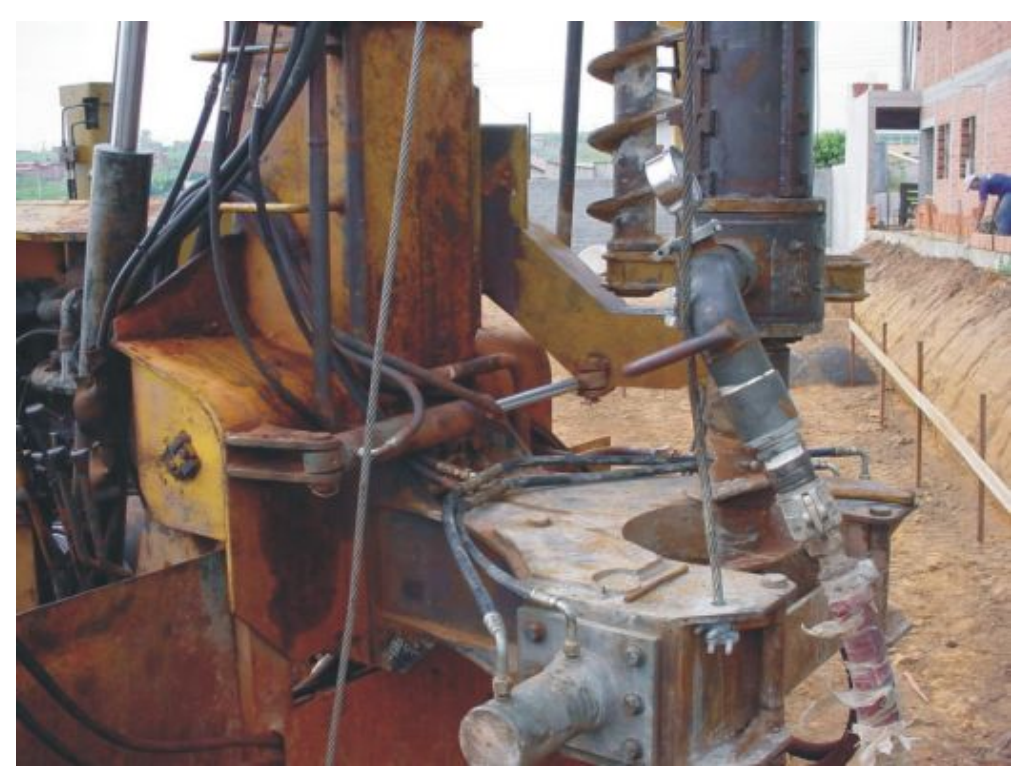

Figura 3.37 - Detalhe da morsa e cilindro do alimentador.

\subsubsection{HASTES TELESCÓPICAS}

Foram desenvolvidos dois conjuntos de hastes telescópicas. Um conjunto composto de cinco elementos, para a aplicação na execução de estacas escavadas, tubulões e estacas do tipo "hollow-auger" (Figura 3.38). Um outro conjunto composto de dois elementos, para a aplicação na execução de estacas do tipo "hélice segmentada” (Figura 3.39).

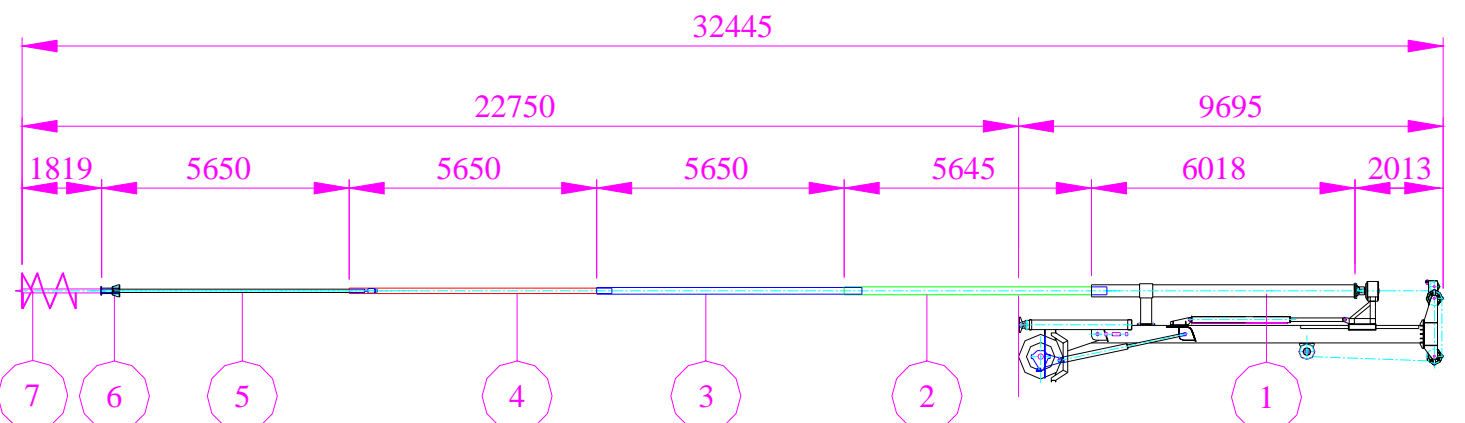

\begin{tabular}{|c|l|c|}
\hline 1 & TRADO & 7 \\
\hline 1 & APOIO DAS HASTES & 6 \\
\hline 1 & HASTE 1 & 5 \\
\hline 1 & HASTE 2 & 4 \\
\hline 1 & HASTE 3 & 3 \\
\hline 1 & HASTE 4 & 2 \\
\hline 1 & HASTE 5 & 1 \\
\hline QDE & DISCRIMINAÇ̃̃ & ITEM \\
\hline
\end{tabular}

Figura 3.38 - Haste telescópica de cinco elementos. 

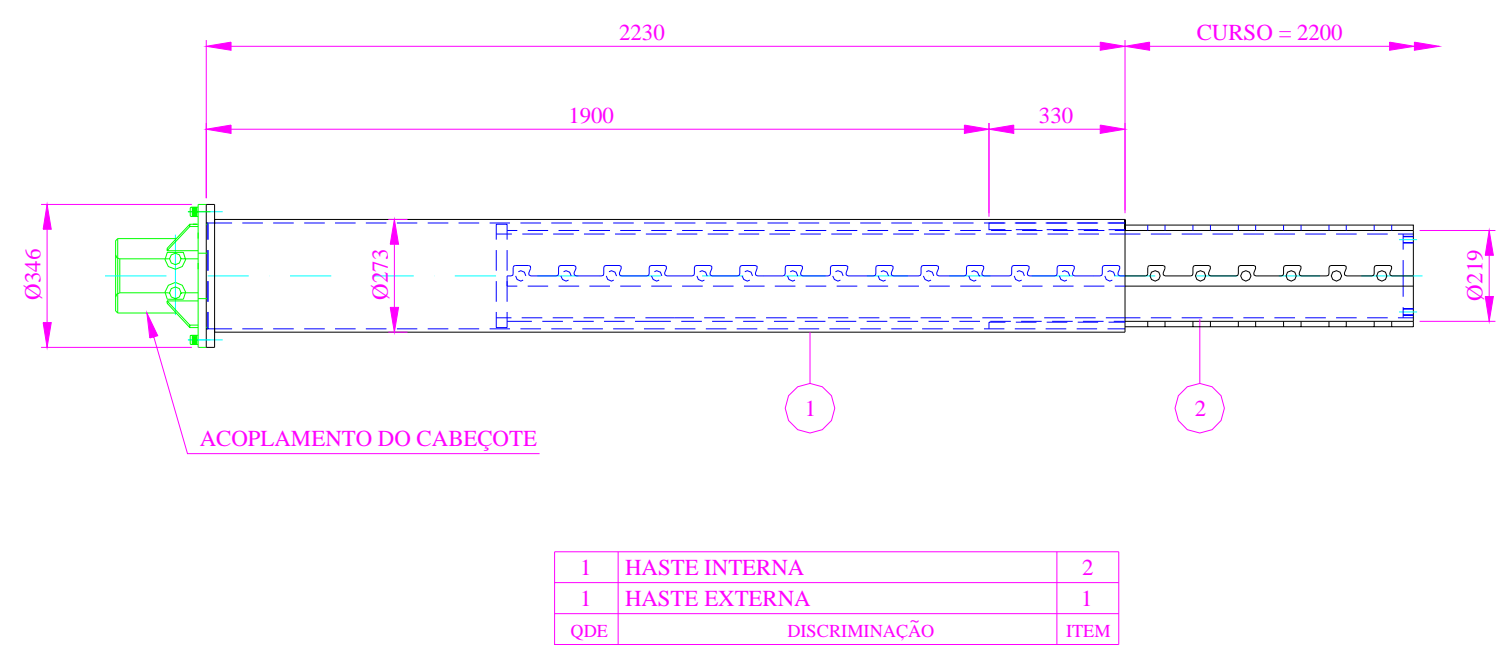

Figura 3.39 - Haste telescópica de dois elementos.

No conjunto telescópico de cinco elementos (Figura 3.40) a haste $\mathrm{n}^{\mathrm{o}} 01$ é quadrada e é maciça. Na extremidade superior desta haste é fixado o girador, também conhecido como "swivel” (Figura 3.43) e na outra extremidade (inferior) são fixados o trado (Figura 3.41) um acoplamento (apoio das hastes) que tem a função de conduzir as demais hastes quadradas para cima. Na Figura 3.42 pode ser visto o equipamento utilizando a haste de 5 elementos.

O conjunto telescópico de dois elementos (Figura 3.44) tem a função de auxiliar no processo de empuxo axial para baixo durante a etapa de escavação e para cima na etapa de extração da hélice. Como cada trado segmentado tem 3,50 m e o curso do cilindro de empuxo axial é de 2,00 m, a haste telescópica de dois elementos (prolonga) que tem curso de 2,20 m possibilita o trabalho de avanço e extração de trados segmentados de $3,5 \mathrm{~m}$.

O elemento interno é dotado de ranhuras que possibilitam o empuxo axial efetivo (Figura 3.45), ou seja, as forças de penetração e de extração da hélice não são dependentes do atrito entre as hastes mas sim da capacidade do cilindro hidráulico. 


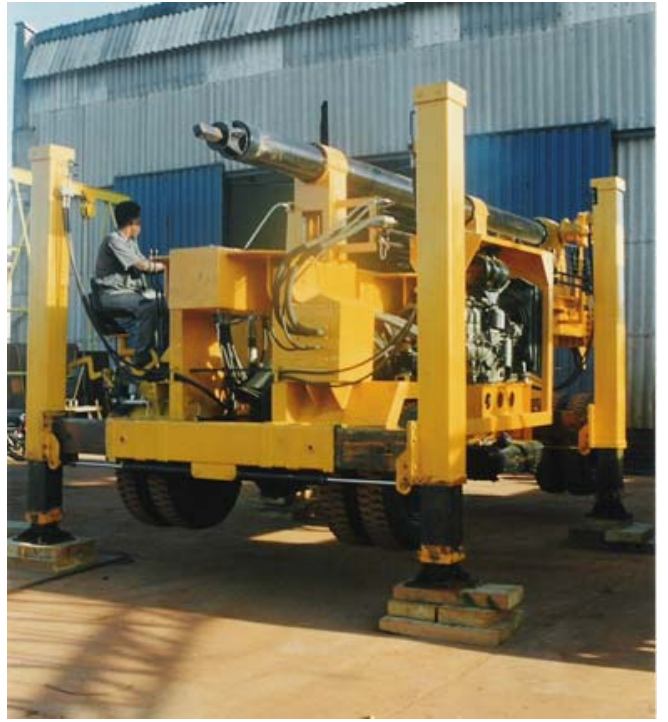

Figura 3.40 - Vista do equipamento com conjunto telescópico de cinco elementos.

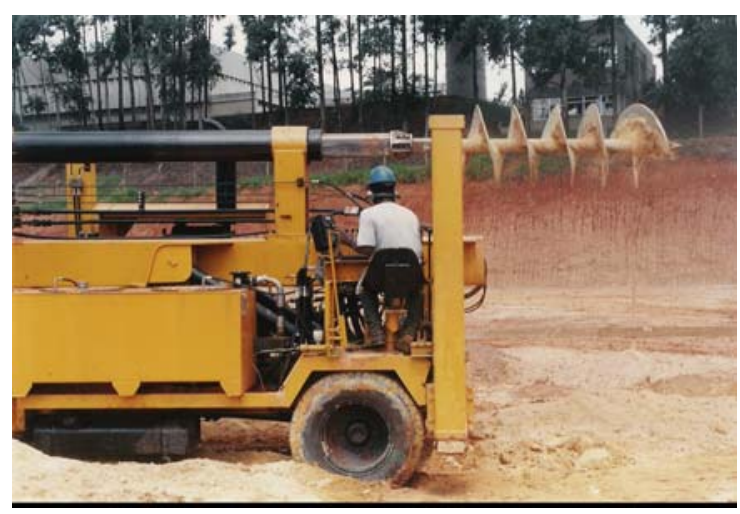

Figura 3.42 - Vista da haste $\mathrm{n}^{\mathrm{o}} 5$ (circular), $\mathrm{n}^{-} 4$ (tubo quadrado), $\mathrm{n}^{\mathrm{o}} 1$ (quadrado maciço) e trado.

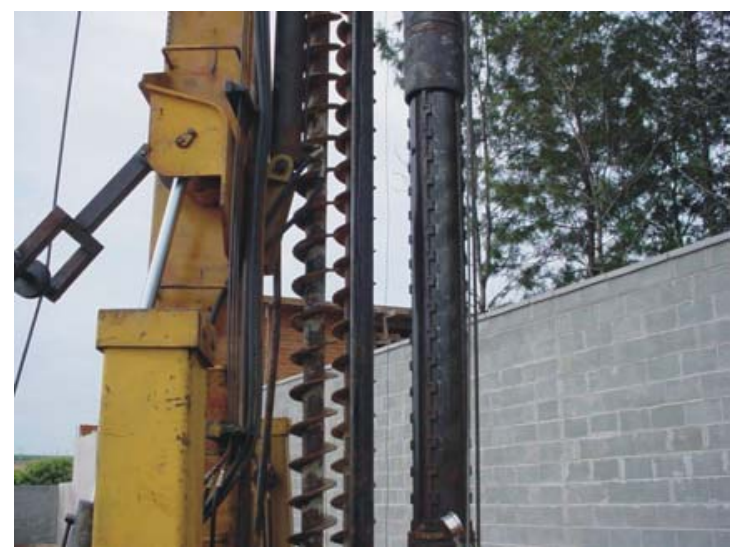

Figura 3.44 - Haste de dois elementos (prolonga).

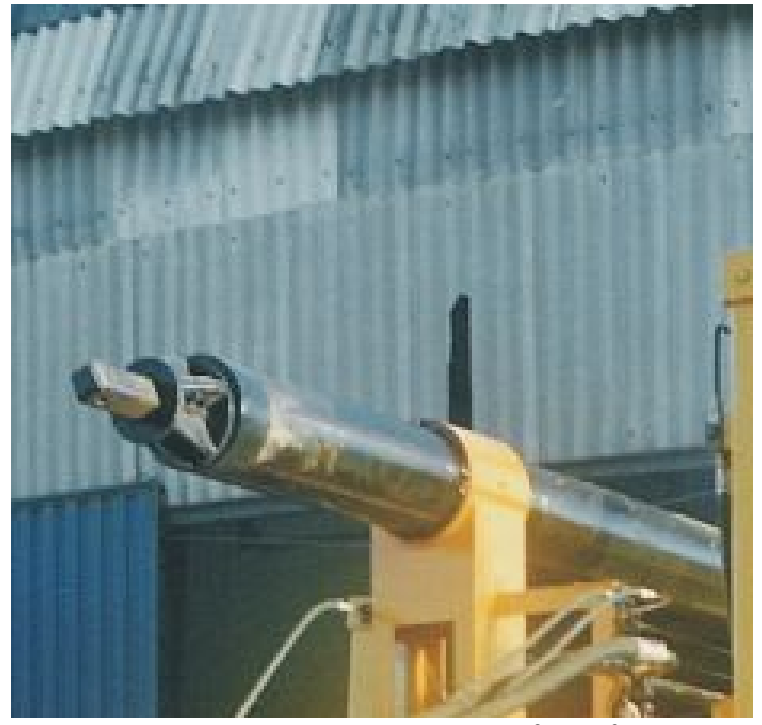

Figura 3.41 - Detalhe das hastes $\mathrm{n}^{\mathrm{O}} 1 \mathrm{e} \mathrm{n}^{\mathrm{o}} 5 \mathrm{e}$ do apoio das hastes.

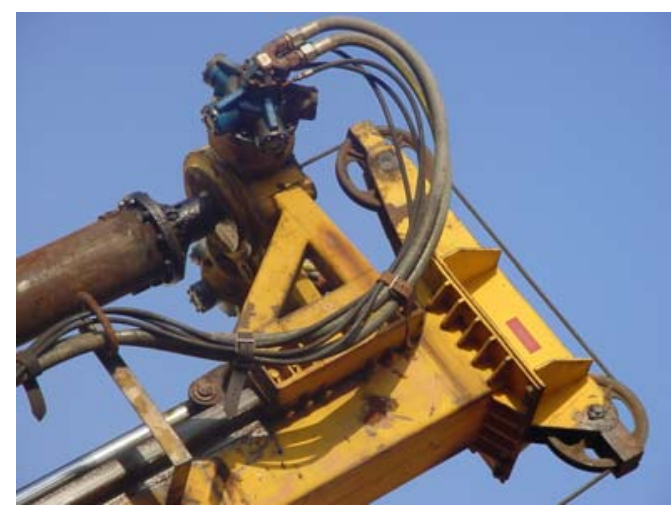

Figura 3.43 - Vista da parte superior do conjunto de hastes telescópicas.

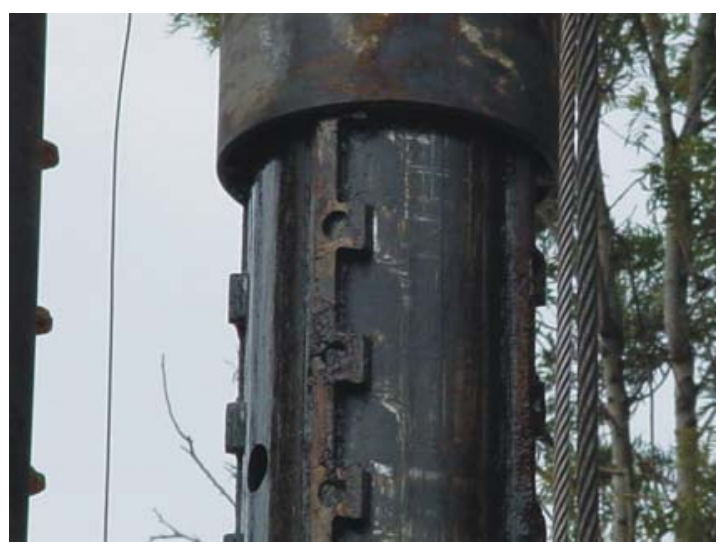

Figura 3.45 - Haste de dois elementos (detalhe das ranhuras na haste interna).

\subsubsection{DISPOSITIVO DE INJEÇÃO DE ARGAMASSA}

Esse conjunto conhecido como girador, ou ainda swivel, é composto basicamente por uma carcaça externa, que é fixa e um tubo interno ligado à haste telescópica de dois 
elementos. A mangueira de injeção é ligada a um tubo que por sua vez é fixado na parte externa do swivel (parte não rotativa). Nesse tubo, existe uma abertura com um flange adequado à fixação de um manômetro analógico ou digital responsável pela obtenção das pressões de injeção da argamassa. As Figuras 3.46 e 3.47 mostram respectivamente, um desenho e uma fotografia desse conjunto.

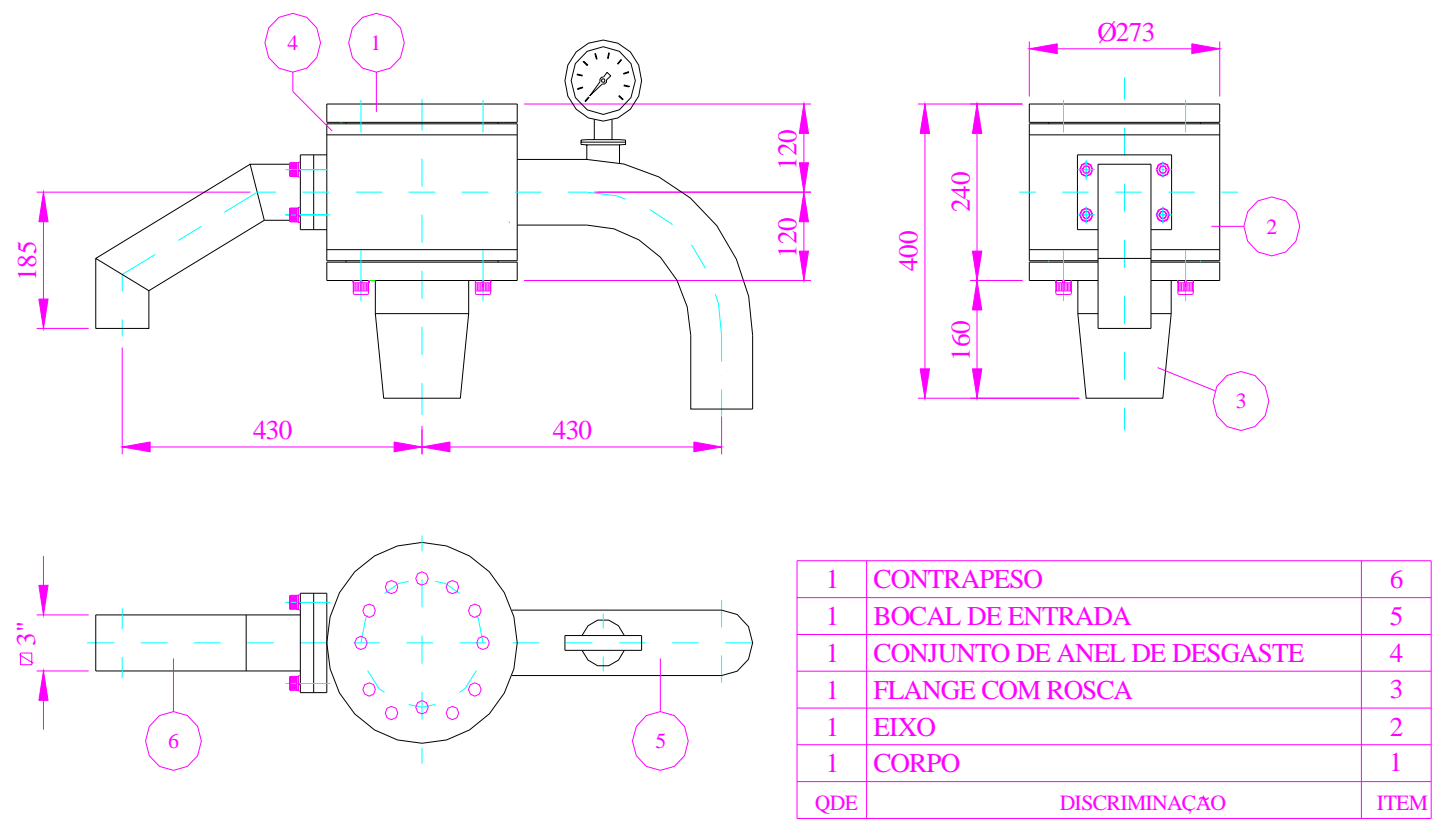

Figura 3.46 - Dispositivo de injeção de argamassa.

A abertura interna do swivel é em falsa elipse e a menor dimensão é igual a $75 \mathrm{~mm}$, o que possibilita a injeção de concreto com utilização de brita 0 (pedrisco) que é um dos agregados utilizados nos concretos aplicados nas estacas do tipo hélice contínua. Portanto, a aplicação de argamassa ou concreto, é uma opção a ser feita para cada caso de obra, levando-se em consideração as necessidades de produção e as condições econômicas e técnicas.

\subsubsection{SISTEMA DE MONITORAMENTO DAS PRESSÕES DE INJEÇÃO}

O monitoramento das pressões de injeção é feito pelo operador durante a fase de extração da hélice segmentada. O sistema pode ser analógico (Figura 3.48) ou digital (Figura 3.49). O manômetro analógico custa aproximadamente US\$200,00 enquanto o digital custa aproximadamente US\$500,00. No entanto, a utilização do manômetro digital é bem mais prática já que a leitura é facilitada pelo fato de que apenas o transmissor fica instalado no tubo de entrada do sistema de injeção e o receptor pode ser instalado em qualquer posição próxima do operador. 


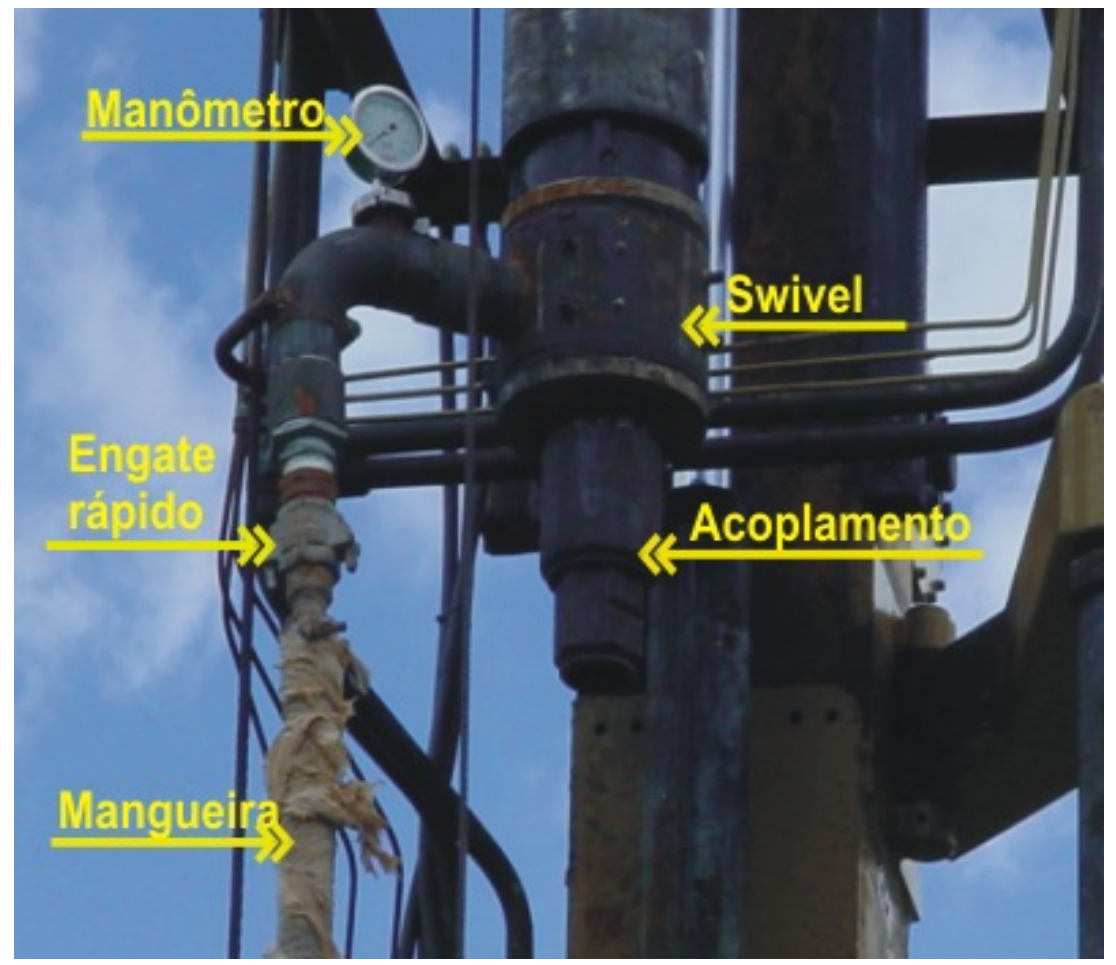

Figura 3.47 - Vista do swivel com manômetro analógico instalado na entrada da argamassa ou concreto.

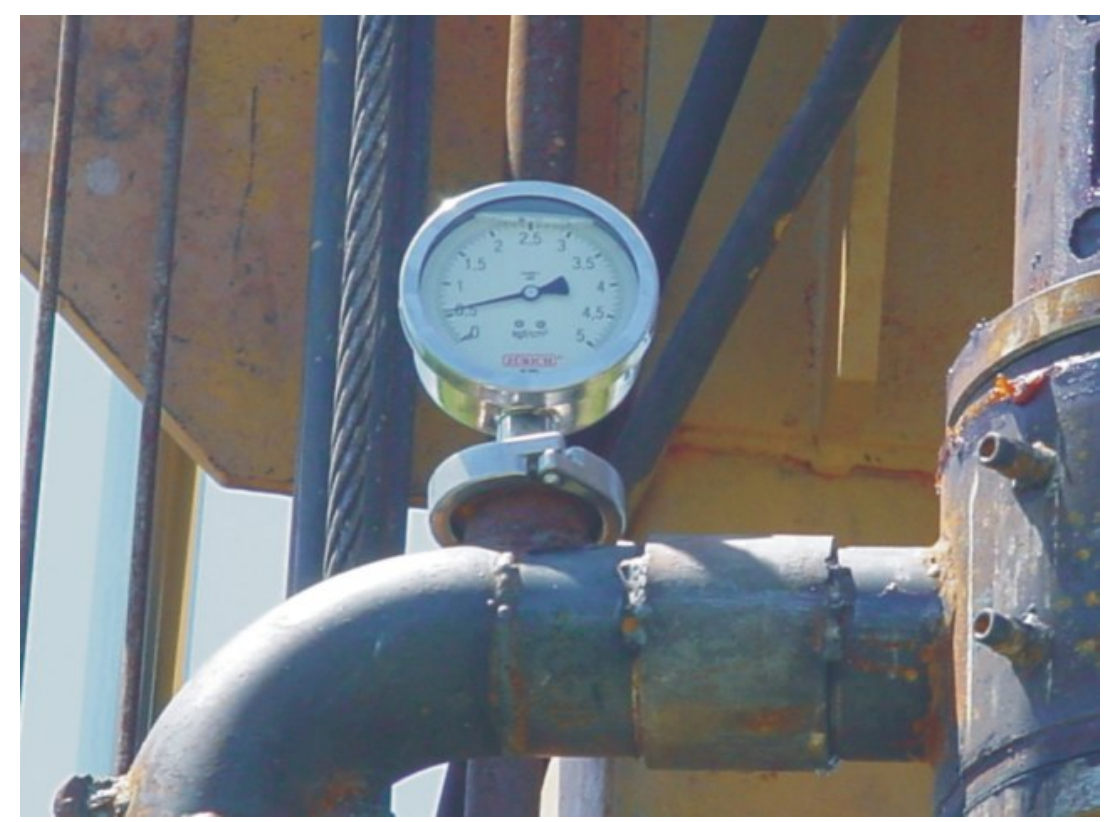

Figura 3.48 - Manômetro analógico.

O manômetro analógico tem fundo de escala igual a 5 bar sendo que a menor divisão desse instumento é de 0,20 bar. O manômetro digital tem precisão de 0,10 bar, faz leituras de até 10 bar e tem sistema de proteção contra sobrepressões de até 20 bar. 


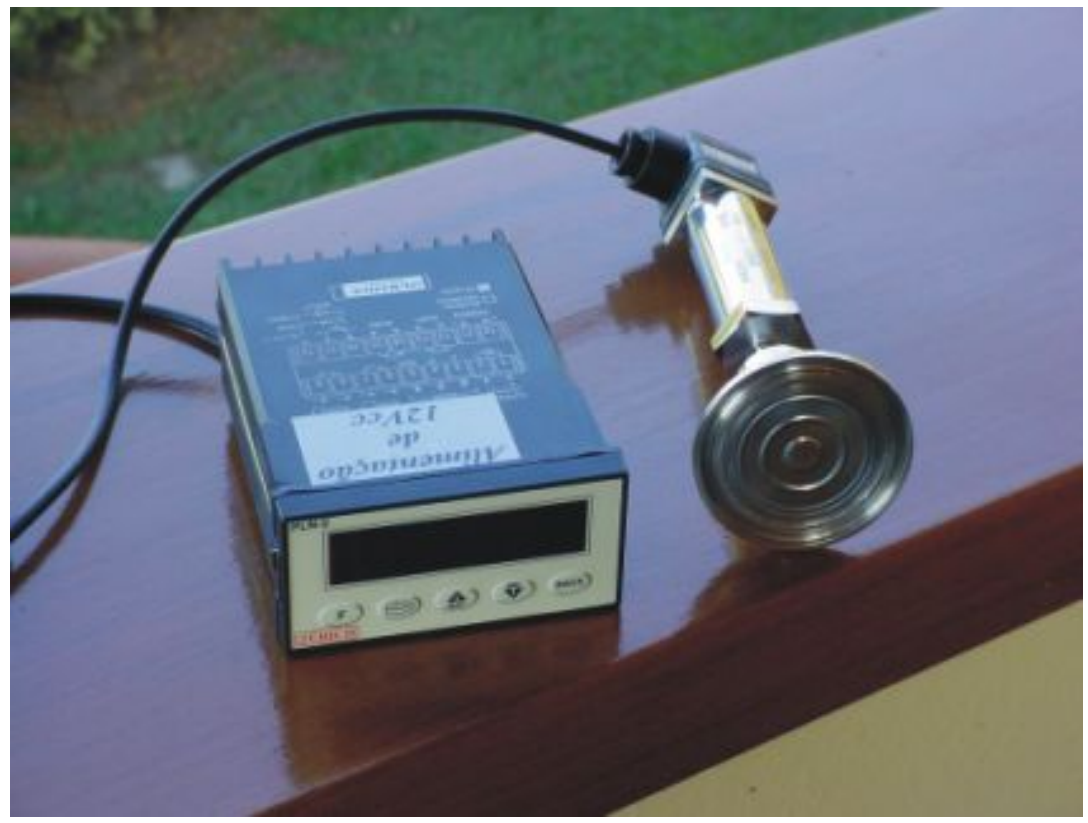

Figura 3.49 - Manômetro digital composto de um transmissor e um receptor.

\subsubsection{CONJUNTO DAS ROLDANAS}

Os guinchos, principal e auxiliar, foram projetados utilizando-se cabos de aço alojados em tubos de aço (rolos). Os cabos de aço tem a função de transmitir esforços de tração e normalmente passam por roldanas para possibilitar as mudanças de direção necessárias à aplicação desejada.

No presente trabalho desenvolveu-se um “conjunto das roldanas” constituído por uma estrutura metálica que pudesse receber as roldanas utilizadas pelo cabo do guincho principal e do guincho auxiliar. Cada roldana é dotada de dois rolamentos que se apóiam em um pino fixado à estrutura do conjunto.

Uma das roldanas utilizadas pelo cabo de aço do guincho auxiliar foi projetada com um avanço em direção à parte frontal da torre, para facilitar as operações de manobra (Figura 3.50). As roldanas necessárias à passagem do cabo de aço do guincho principal foram posicionadas de tal forma que a da parte frontal da torre propiciou a passagem do cabo em direção ao centro do eixo de saída do cabeçote rotativo e a da parte traseira da torre permitiu uma inclinação no cabo, responsável pelo aparecimento de uma força horizontal favorável, já que provoca um momento fletor contrário ao momento originado pela força de tração no conjunto de hastes telescópicas. A Figura 3.51 mostra 
uma vista do conjunto das roldanas já pronto e montado na extremidade superior da torre.
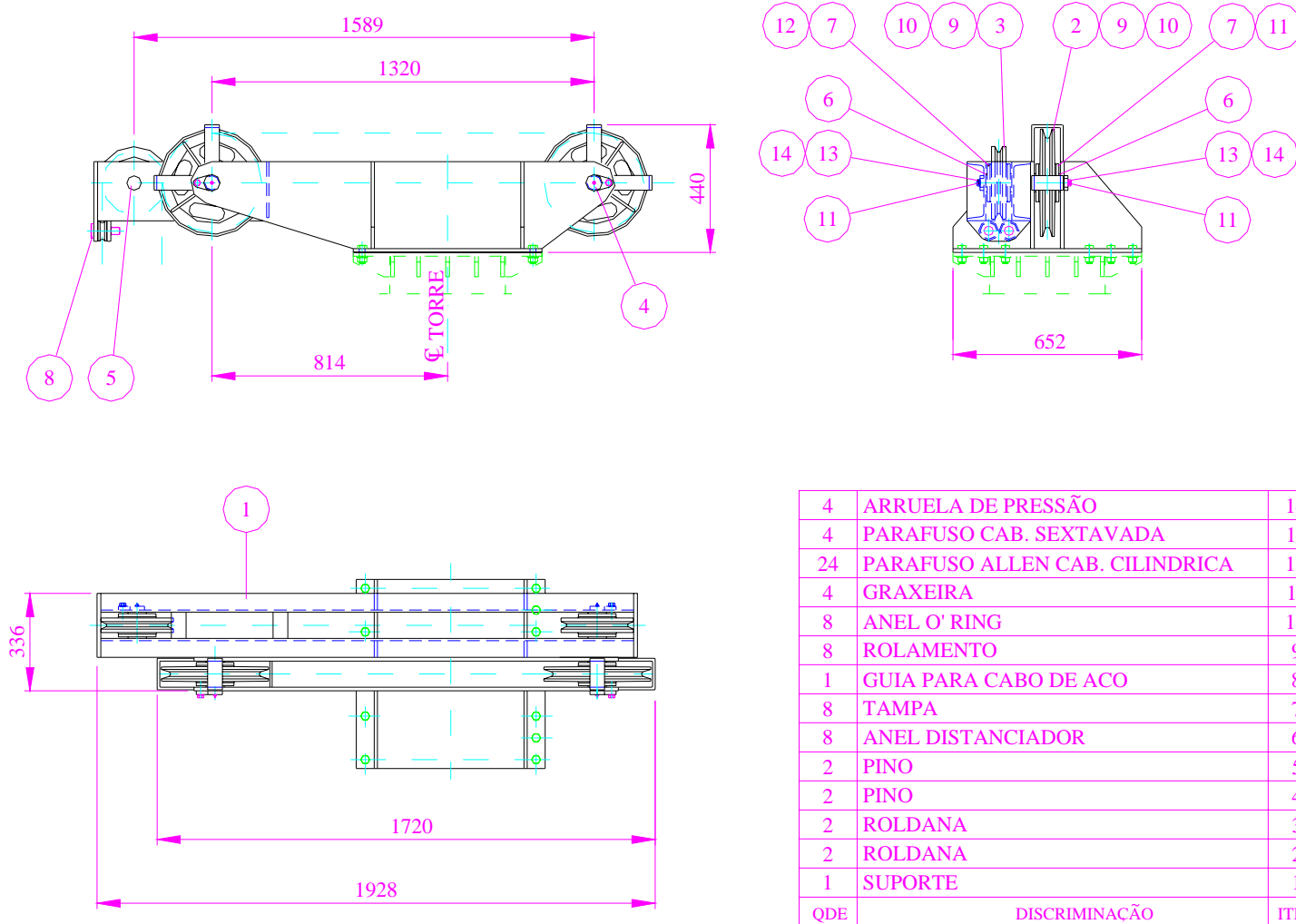

\begin{tabular}{|c|l|c|}
\hline 4 & ARRUELA DE PRESSÃO & 14 \\
\hline 4 & PARAFUSO CAB. SEXTAVADA & 13 \\
\hline 24 & PARAFUSO ALLEN CAB. CILINDRICA & 12 \\
\hline 4 & GRAXEIRA & 11 \\
\hline 8 & ANEL O' RING & 10 \\
\hline 8 & ROLAMENTO & 9 \\
\hline 1 & GUIA PARA CABO DE ACO & 8 \\
\hline 8 & TAMPA & 7 \\
\hline 8 & ANEL DISTANCIADOR & 6 \\
\hline 2 & PINO & 5 \\
\hline 2 & PINO & 4 \\
\hline 2 & ROLDANA & 3 \\
\hline 2 & ROLDANA & 2 \\
\hline 1 & SUPORTE & 1 \\
\hline QDE & & ITEM \\
\hline
\end{tabular}

Figura 3.50 - Desenho do conjunto das roldanas

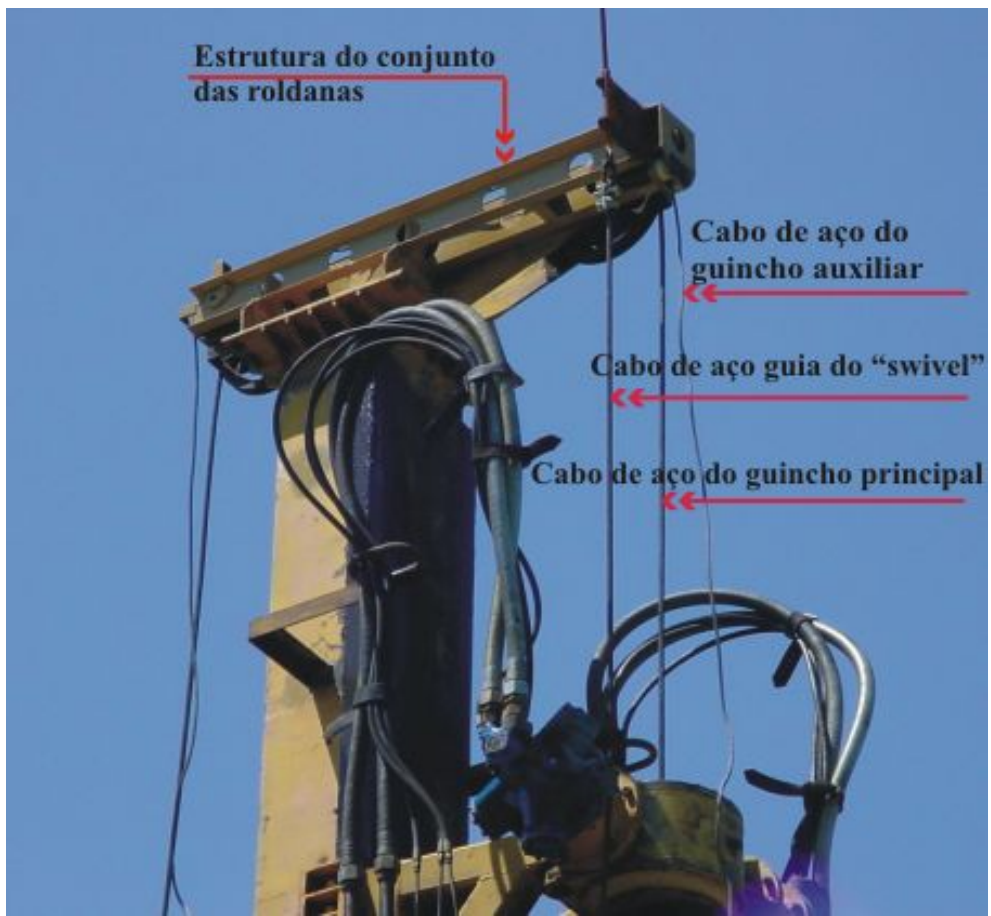

Figura 3.51 - Vista do conjunto das roldanas. 
A estrutura da perfuratriz, considerada estática, foi dimensionada respeitando-se a norma brasileira NBR 8800/1986: Projeto e execução de estruturas de aço de edifícios. Trabalhou-se com tensões de flexão entre 30 e $60 \mathrm{MPa}$, com o objetivo de garantir a rigidez do conjunto. De modo geral, os perfis de aço utilizados foram superdimensionados do ponto de vista dos esforços e normalmente dimensionados do ponto de vista da flexibilidade. Os elementos submetidos a esforços de cisalhamento foram dimensionados utilizando-se fatores de segurança entre quatro e seis, visando a segurança das pessoas envolvidas na obra.

\subsubsection{SISTEMA HIDRÁULICO}

Com o desenvolvimento de novos materiais e fluidos sintéticos, o uso da transmissão de energia através de sistemas hidráulicos tornou-se comum desde a aplicação em um simples sistema de frenagem em um automóvel até sistemas sofisticados como os utilizados nas aeronaves e mísseis (Palmieri, 1985).

Os sistemas óleo-hidráulicos transmitem força e movimento utilizando o óleo que sob pressão é praticamente incompressível. Os sistemas óleo-hidráulicos que utilizam pressões elevadas e baixas velocidades são conhecidos como sistemas estáticos e os que utilizam altas velocidades e pressões baixas são chamados cinéticos.

O equipamento objeto da presente dissertação de mestrado foi desenvolvido utilizando-se um sistema hidráulico onde as pressões de trabalho variam de 80 a 180 bar (8 a $18 \mathrm{MPa}$ ) e as velocidades do óleo variam de 2 a $5 \mathrm{~m} / \mathrm{s}$ nas linhas de pressão e 0,50 a $1,50 \mathrm{~m} / \mathrm{s}$ nas linhas de sucção (Rexroth, 87).

Usou-se na linha de sucção um tubo com diâmetro interno $\left(d_{i}\right)$ igual a $90 \mathrm{~mm}$ cuja área da seção transversal é igual a $0,00636 \mathrm{~m}^{2}\left(A_{t}=0,00636 \mathrm{~m}^{2}\right)$. A vazão total do sistema hidráulico é de $430 \mathrm{l} / \mathrm{min}\left(Q_{f}=430 \mathrm{l} / \mathrm{min}\right)$ que corresponde a $0,00717 \mathrm{~m} / \mathrm{s}$.

Sabendo-se que a velocidade de um fluido é definida pela expressão:

$$
V_{f}=\frac{Q_{f}}{A_{t}}
$$

$$
\text { tem-se: } V_{f}=\frac{0,00717}{0,00636}=1,13 \mathrm{~m} / \mathrm{s} \therefore \quad 0,50<V_{f}<1,50 \mathrm{~m} / \mathrm{s}
$$

Para a linha de pressão com vazão de 190 l/min adotaram-se tubos e mangueiras hidráulicas com diâmetros internos de no mínimo 31,8 $\mathrm{mm}$. Dessa forma obteve-se: 


$$
V_{f}=\frac{0,00317}{0,000794}=3,99 \mathrm{~m} / \mathrm{s} \quad \therefore \quad 2<V_{f}<5 \mathrm{~m} / \mathrm{s}
$$

Para a linha de pressão do circuito auxiliar, com vazão de $50 \mathrm{l} / \mathrm{min}$, adotaram-se mangueiras e tubos com diâmetros internos mínimos de 12,7 mm, obtendo-se a seguinte velocidade do fluido:

$$
V_{f}=\frac{0,000833}{0,0001267}=6,57 \mathrm{~m} / \mathrm{s}
$$

A velocidade de $6,57 \mathrm{~m} / \mathrm{s}$ está acima do valor máximo recomendado que é de $5 \mathrm{~m} / \mathrm{s}$, no entanto, foi aceito já que essa linha realiza trabalhos intermitentes quando a vazão é de $50 \mathrm{l} / \mathrm{min}$ sendo que na maioria das vezes as operações auxiliares tais como manobras, carregamento etc., são feitas com a rotação do motor diesel abaixo de 1800 rpm o que faz com que essa bomba trabalhe com vazão da ordem de $35 \mathrm{l} / \mathrm{min}$. Dessa forma têm-se:

$$
V_{f}=\frac{0,0005833}{0,0001267}=4,60 \mathrm{~m} / \mathrm{s}
$$

e que , portanto, é menor que a velocidade máxima recomendada, de $5 \mathrm{~m} / \mathrm{s}$.

Para cada motor hidráulico utilizado, calculam-se o torque e a rotação no eixo pela seguinte expressão:

$$
T_{m}=T_{e} p
$$

onde:

$T_{m}=$ Torque no eixo do motor hidráulico $(k N m)$.

$T_{e}=$ Torque específico do motor hidráulico, fornecido pelo fabricante $(\mathrm{kNm} / \mathrm{bar})$.

$p$ = pressão hidráulica na entrada do motor (bar).

E o torque de saída nos guinchos e no cabeçote rotativo é expresso por:

$$
T s=T_{m} \mu \eta
$$


em que: $T s=$ torque no eixo de saída do redutor $(\mathrm{kNm})$.

$\mu=$ relação de transmissão do redutor.

$\eta=$ rendimento do conjunto.

Para o cabeçote rotativo, por exemplo, tem-se:

$$
T_{m}=T_{e} p
$$

$T_{m}=0,00825.175=1,44 \mathrm{kNm}$

E para pressão de 200 bar tem-se:

$T_{m}=0,00825.200=1.65 \mathrm{kNm}$

$$
\text { Como: } T_{s}=T_{m} \mu \eta
$$

obtem-se para pressão de 200 bar:

$T_{s}=1,65 \cdot 0,96 \cdot 6,86=10,9 \rightarrow T_{s}=11 \mathrm{kNm}$

Para o cabeçote rotativo com dois motores hidráulicos obtem-se:

$T_{s}=22 \mathrm{kNm}$ que é o torque de pico oferecido no eixo de saída da mesa rotativa ou cabeçote de perfuração como também é denominado.

Para os outros conjuntos que utilizam motores hidráulicos os cálculos são feitos da mesma forma.

Para os guinchos, a força no cabo de aço é dada pela expressão:

$$
F_{c}=\frac{T_{e} \cdot p \cdot \mu \cdot \eta}{r_{t}}
$$

onde: $r_{t}=$ raio do tambor do guincho $(m)$.

$F_{c}=$ força no cabo de aço $(k N)$.

Para $T_{e}=0,00825 \mathrm{kNm} /$ bar; $\mathrm{p}=175$ bar; $\mu=6,86 ; \eta=0,96$ e rt $=0,16 \mathrm{~m}$, obtém-se:

$$
F_{c}=59,4 k N
$$

A seguir, apresentam-se os diversos circuitos hidráulicos do sistema projetado: 


\subsubsection{SUCÇÃO E BOMBEAMENTO}

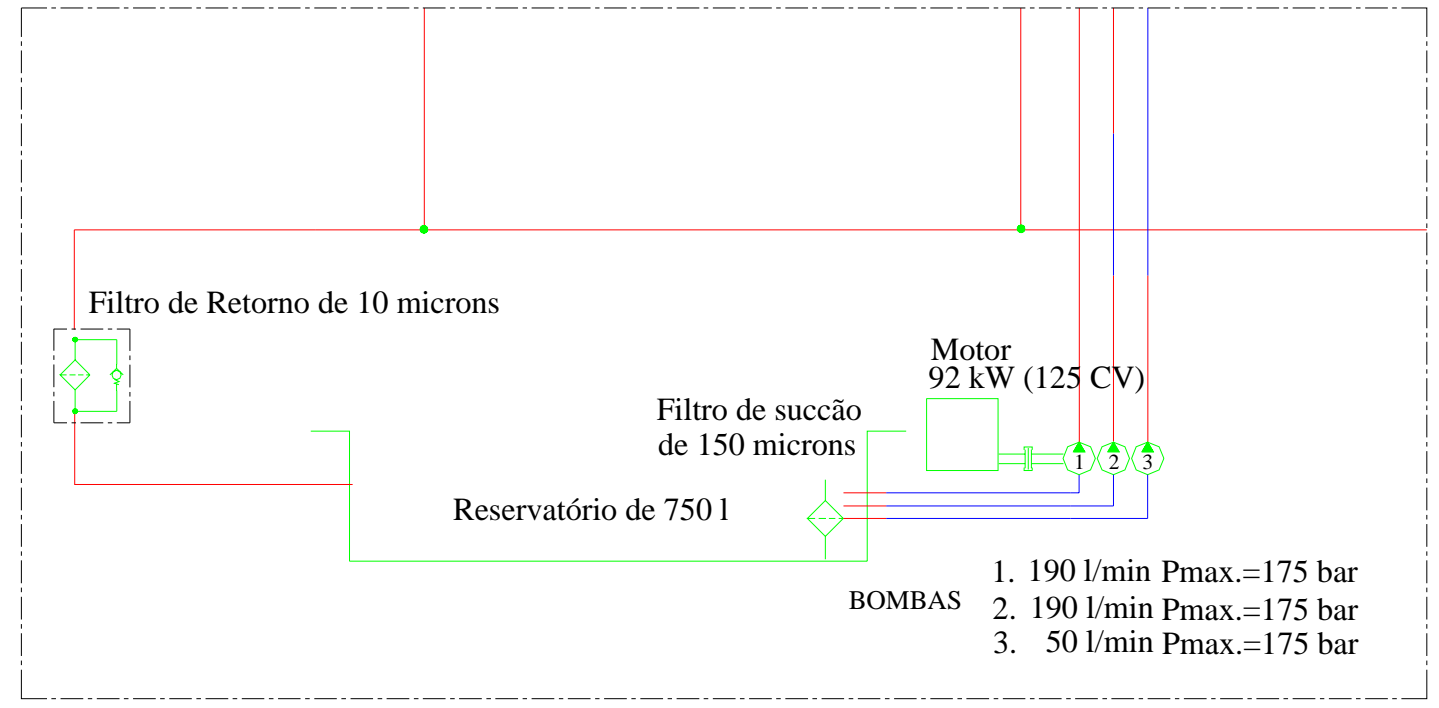

Figura 3.52 - Circuito hidráulico do sistema de sucção e recalque.

\subsubsection{ACIONAMENTO DA MESA ROTATIVA}

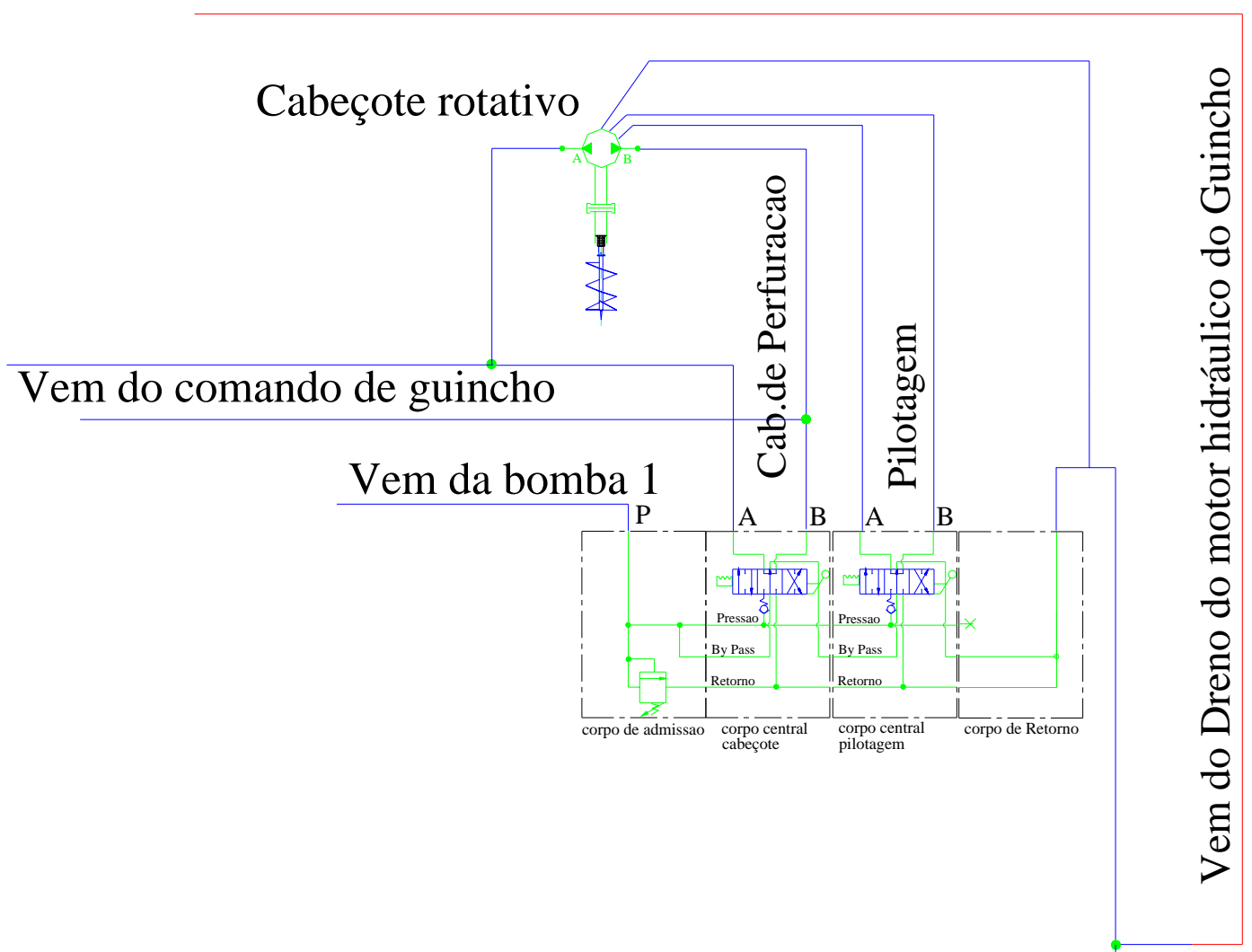

Vai para tanque

Figura 3.53 - Circuito hidráulico da mesa rotativa. 
3.3.17.3. GUINCHO PRINCIPAL

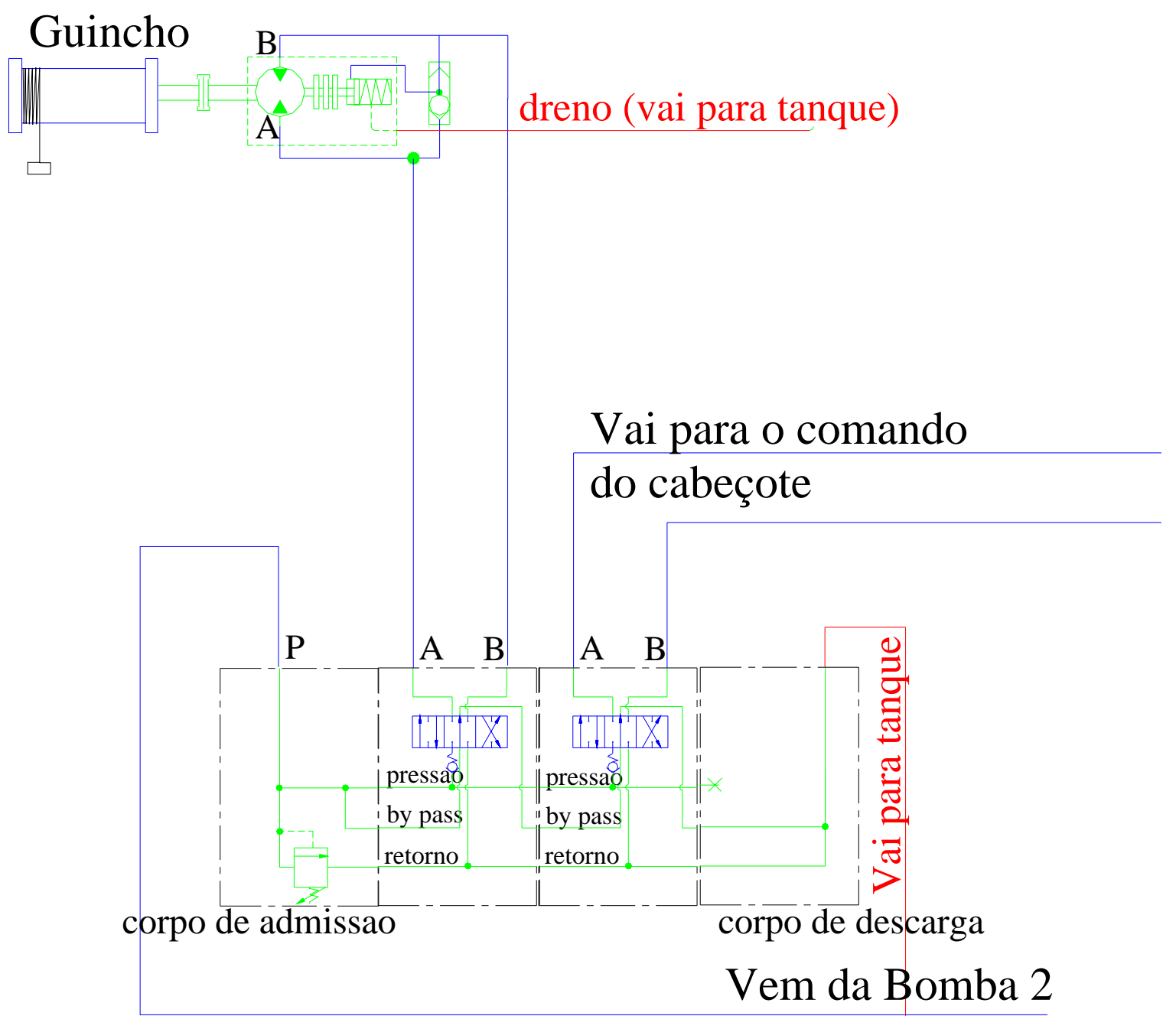

Figura 3.54 - Circuito hidráulico do guincho principal. 


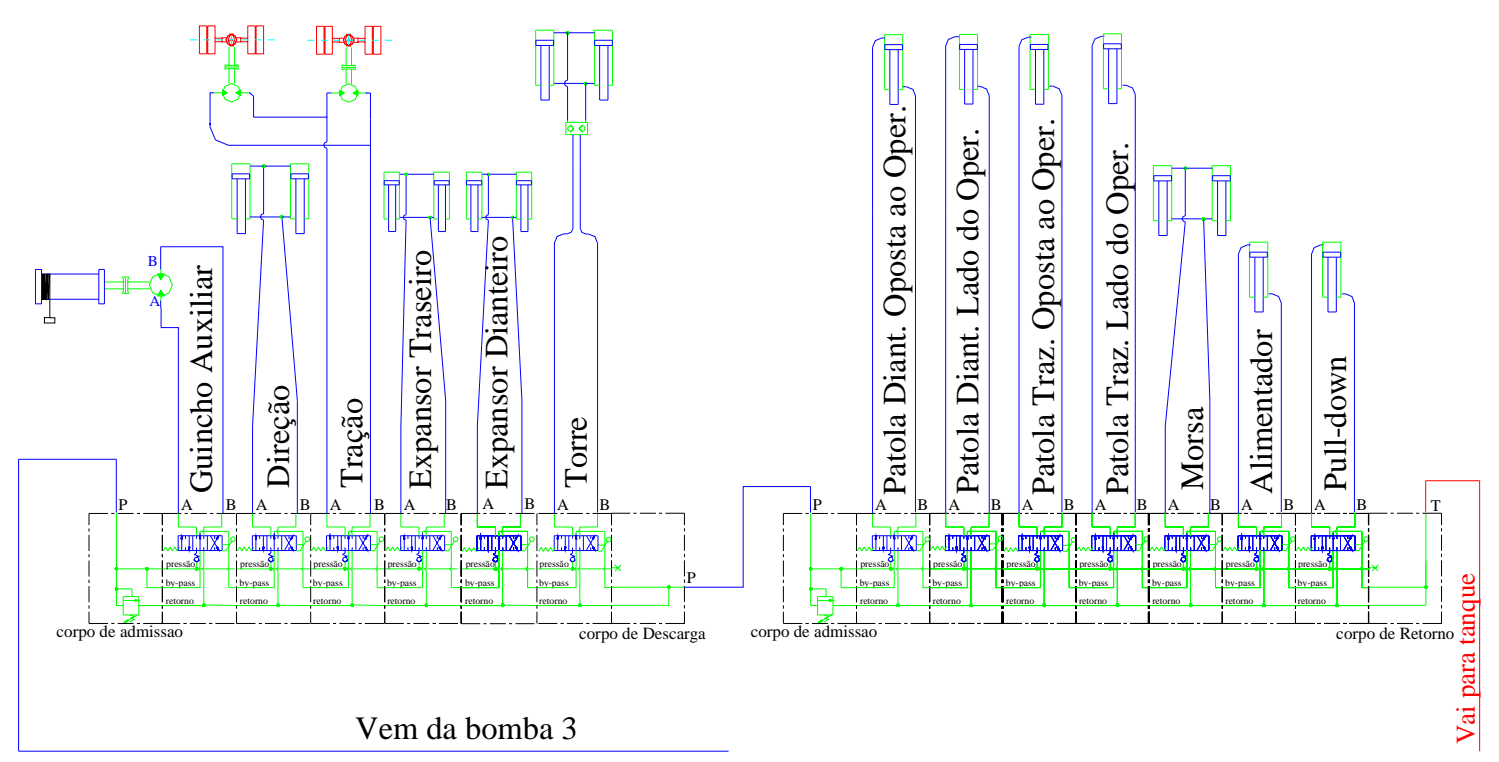

Figura 3.55 - Circuito auxiliar.

\subsubsection{TRADOS}

Desenvolveu-se um tipo de trado para a execução de estacas “hélice segmentada” um outro tipo para a execução de estacas escavadas e tubulões e ainda um último tipo para a execução de estacas do tipo "hollow-auger".

\subsubsection{TRADO SEGMENTADO}

Essa ferramenta foi desenvolvida em módulos de 3,50 m e 1,50 m e nos diâmetros de 0,25 m e 0,30 m (Figura 4.56). O sistema de emendas é semelhante ao utilizado nos trados em hélice contínua, porém, com dimensões reduzidas (Figura 3.57).
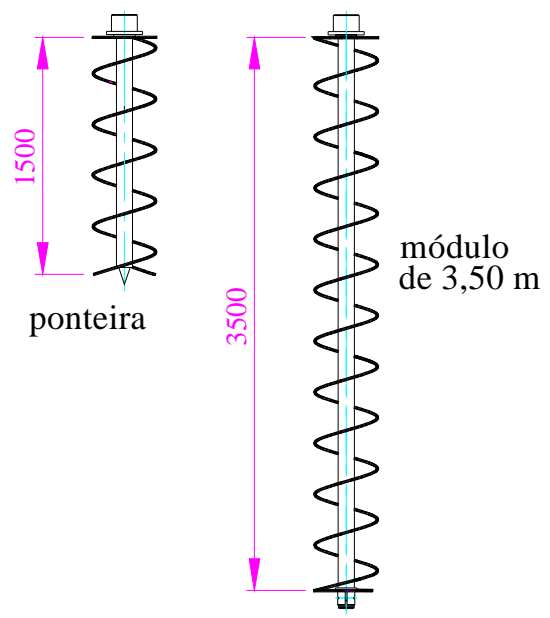

Figura 3.56 - Trados para a execução de estaca hélice segmentada 


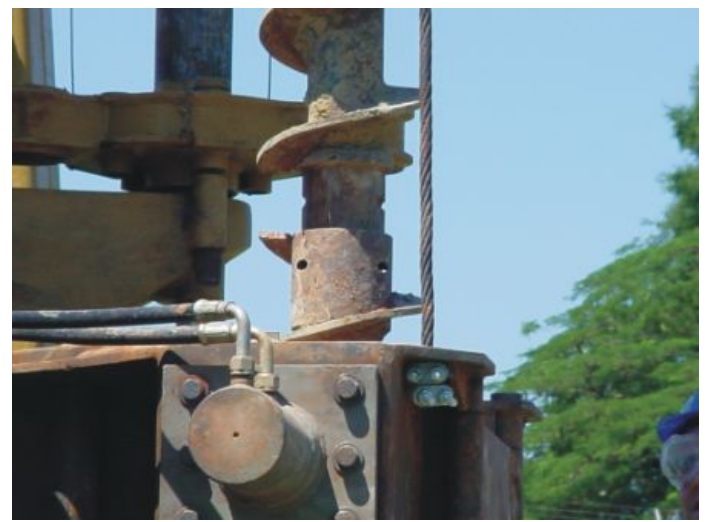

Figura 3.57 - Fase de início da emenda de um segmento de hélice.

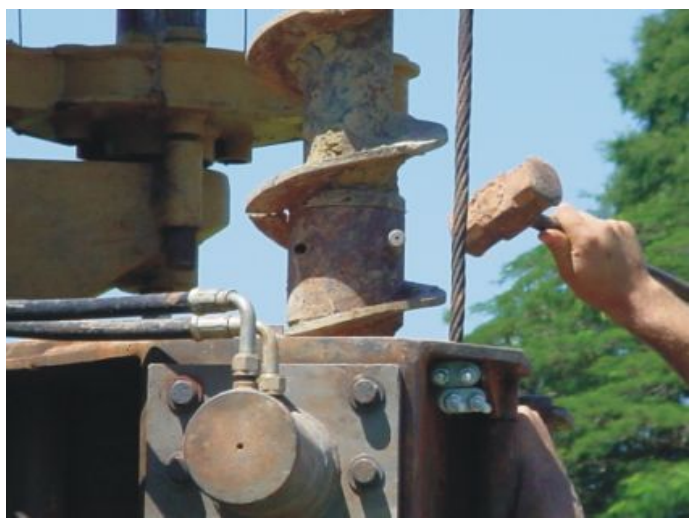

Figura 3.58 - Fase final da emenda de um um segmento de hélice.

O sistema de encaixe tipo "macho - fêmea” com geometria sextavada possibilita a transmissão do torque e os dois pinos com seus eixos longitudinais paralelos entre si e perpendiculares em relação ao eixo da hélice, são responsáveis pela transmissão dos esforços axiais necessários ao avanço e extração da hélice (Figura 3.58). Os pinos trabalham em cisalhamento sendo que para cada um, essa solicitação ocorre num plano vertical que contém o eixo longitudinal do pino.

\subsubsection{TRADO PARA ESTACAS ESCAVADAS E TUBULÕES}

Foi utilizado um trado conhecido na prática como "trado curto", o qual possui em sua extremidade inferior, um conjunto de ferramentas de corte normalmente composto de peças inclinadas (facas) e uma peça vertical conhecida como ponteira (Figura 3.59), e em sua extremidade superior um acoplamento (Figura 3.60) que tem a função de fazer a ligação através de um pino, com a haste quadrada maciça (haste $\mathrm{n}^{\mathrm{o}} 1$ ). $\mathrm{O}$ tubo central é envolvido por um helicóide fabricado em chapa de aço baixo carbono que serve apenas para efetuar o transporte do solo escavado. A Figura 3.61 mostra o equipamento operando com um trado curto na escavação de tubulões.

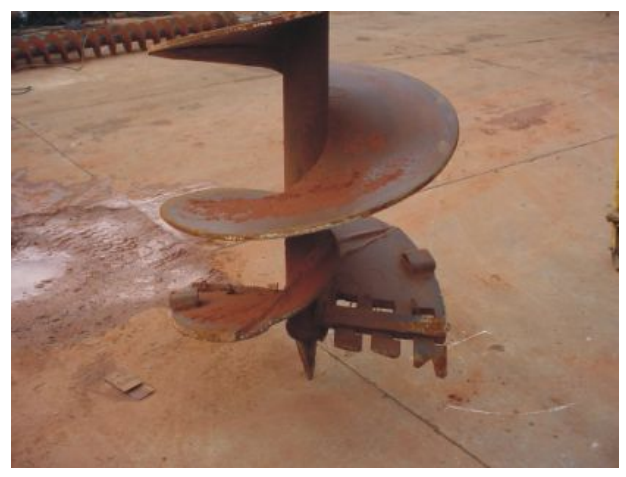

Figura 3.59 - Vista das ferramentas de corte e da hélice de um trado curto.

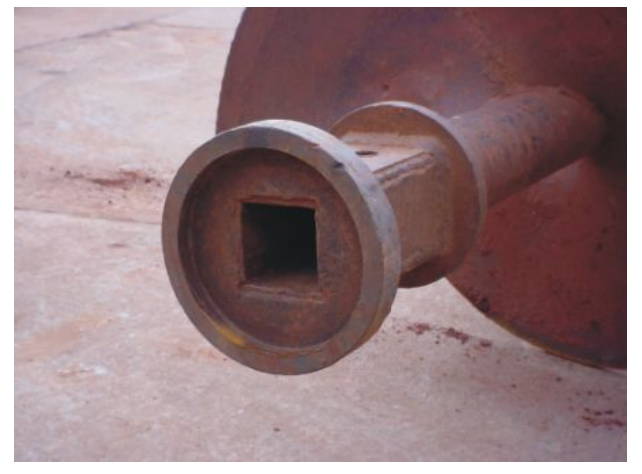

Figura 3.60 - Parte superior de um trado curto. 


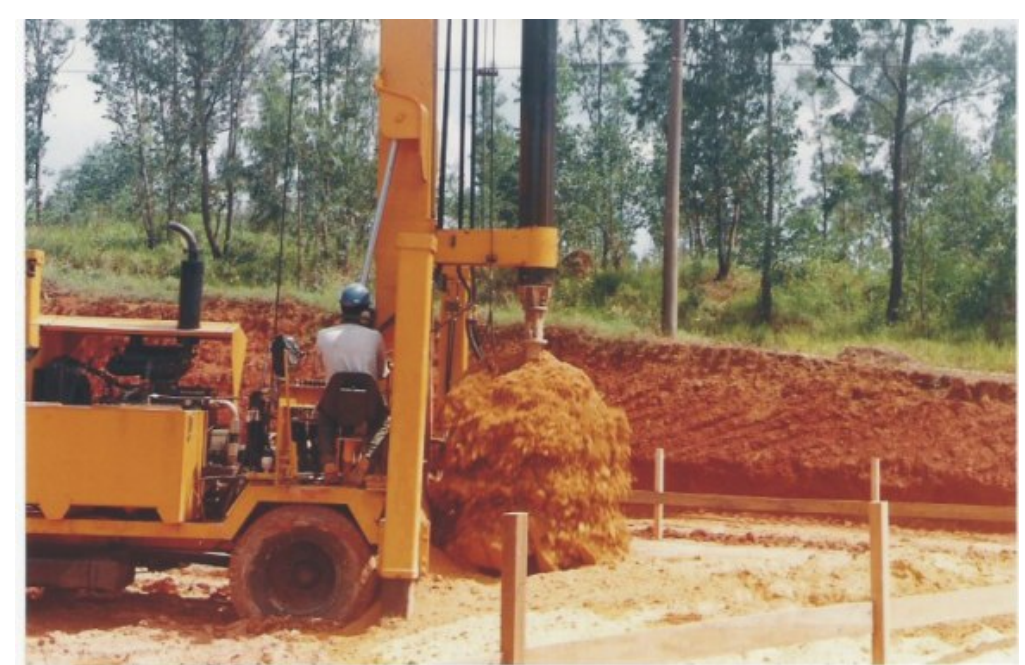

Figura 3.61 - Vista do equipamento escavando um tubulão.

\subsubsection{TRADO PARA ESTACAS “ HOLLOW-AUGER”}

As estacas do tipo "hollow-auger" diferem das estacas do tipo "hélice segmentada" nos seguintes aspectos:

a) Embora sejam utilizados trados segmentados, esses normalmente tem 1,50 m de comprimento, e portanto, são segmentos curtos (Figura 3.62).

b) O sistema de encaixe utiliza-se de chavetas para transmissão do torque e dois parafusos para a transmissão dos esforços axiais que ocorrem na fase de extração dos segmentos (Figura 3.63). Um anel de borracha (anel “O”) é utilizado para melhorar a vedação do conjunto quando instalado abaixo do nível d'água.

c) O diâmetro interno do tubo central é de $150 \mathrm{~mm}$ para trados de $250 \mathrm{~mm}$ e de 300 $\mathrm{mm}$, ao passo que para a hélice segmentada o diâmetro interno do tubo central é de $75 \mathrm{~mm}$.

d) A concretagem não é feita por processo de injeção mas sim lançando-se o concreto no interior do tubo central a partir da superfície do solo ou acima dela (Figura 3.64).

e) Os segmentos são extraídos em conjunto com a concretagem, e não se utiliza nenhum monitoramento mais sofisticado a não ser a observação visual do preenchimento do tubo central pelo concreto.

As Figuras 3.65 e 3.66 mostram o equipamento operando com o trado do tipo "HollowAuger”. 


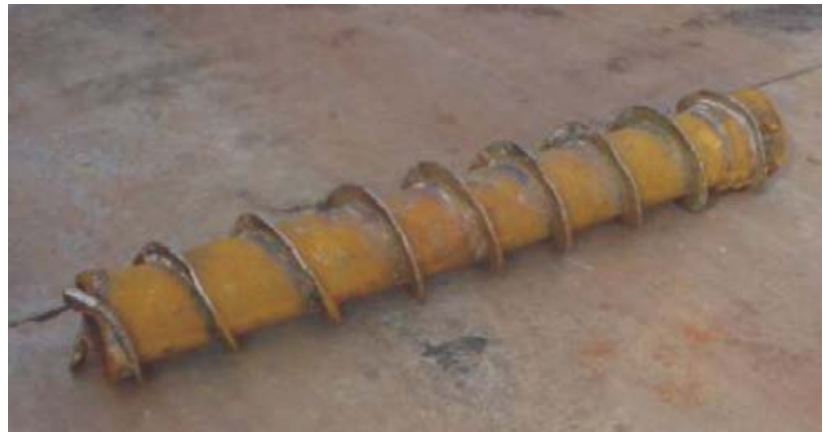

Figura 3.62 - Segmento de trado tipo “Hollow-Auger”.

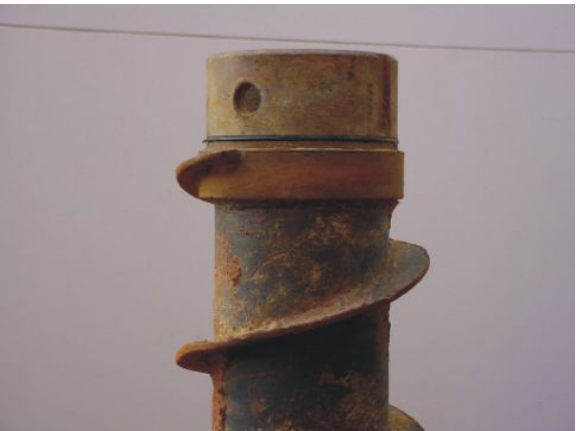

Figura 3.63 - Detalhe do acoplamento do Trado "Hollow-Auger".

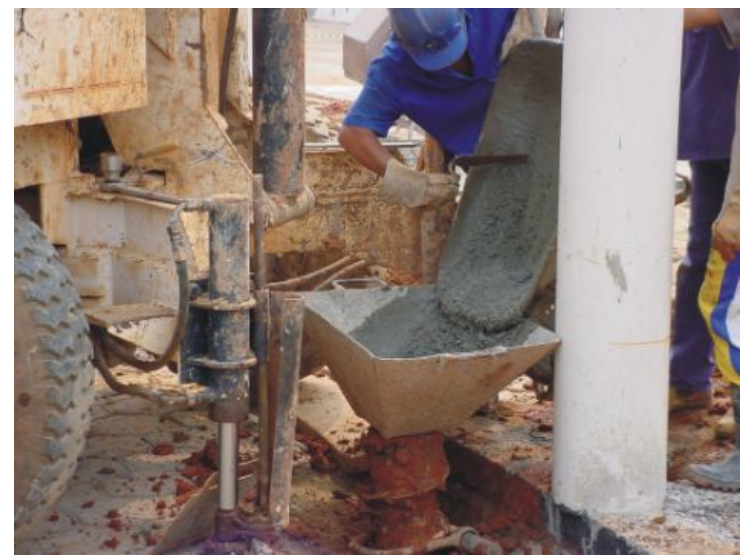

Figura 3.64 - Vista do lançamento de concreto em uma estaca do tipo "Hollow-Auger".

As Figuras 3.65 e 3.66 mostram o equipamento operando com o trado do tipo "HollowAuger”.

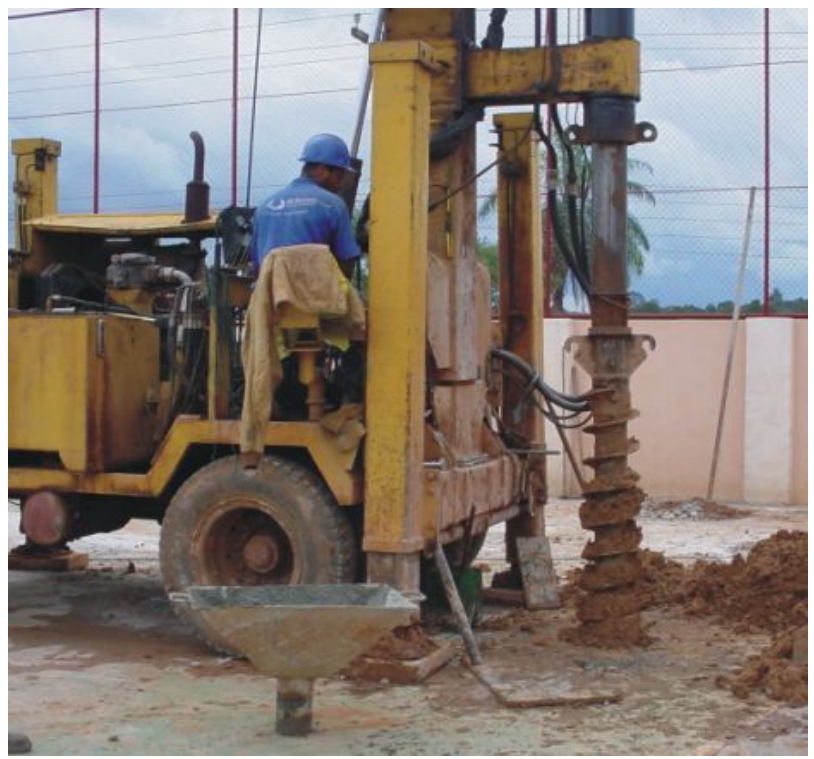

Figura 3.65 - Execução de estaca “Hollow-Auger” com o equipamento na posição de trabalho. 


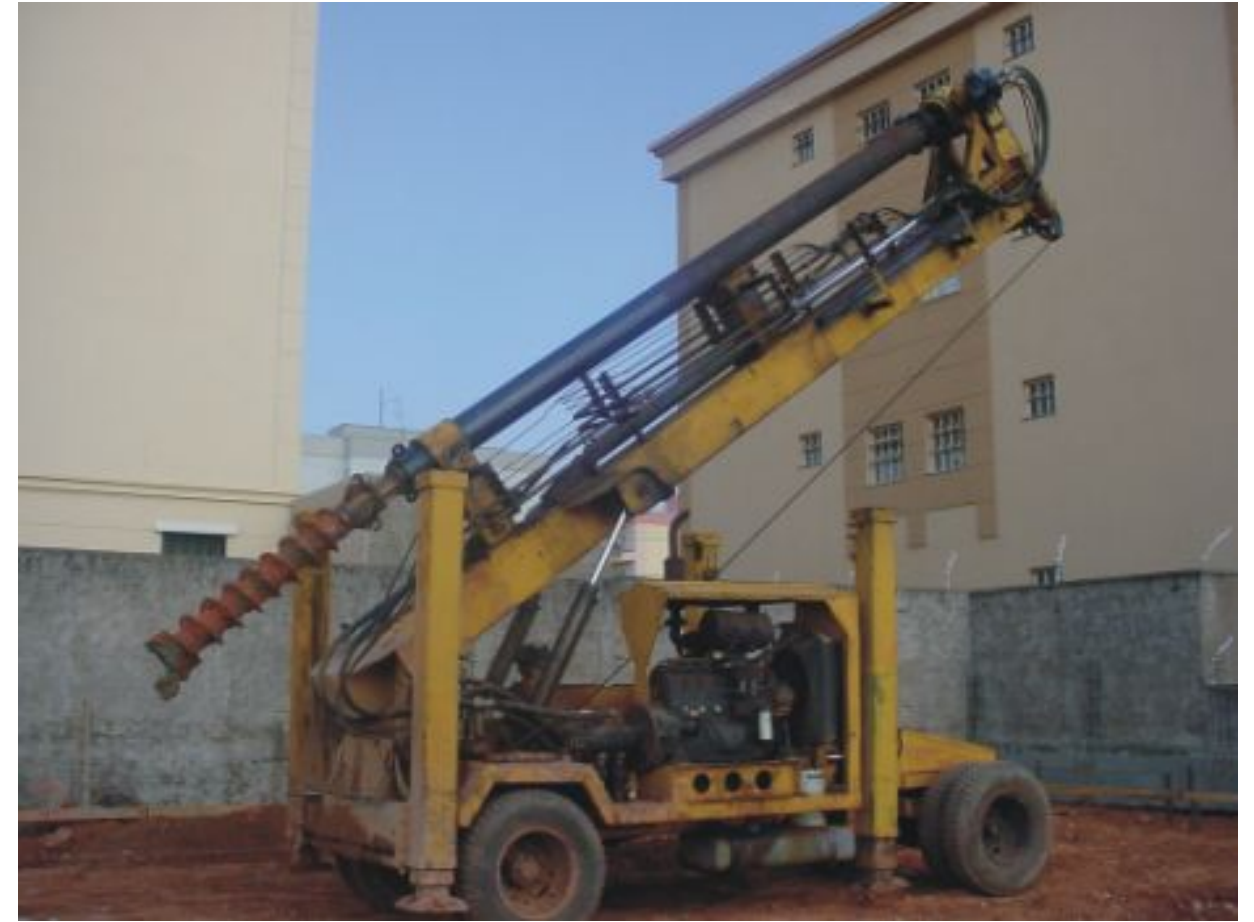

Figura 3.66 - Execução de estacas “Hollow-Auger” com abaixamento da torre para a posição horizontal (posição de manobra). 


\section{CAPÍTULO 4}

\section{PROCESSO EXECUTIVO DA ESTACA}

\subsection{DESCRIÇÃO GERAL}

A estaca hélice segmentada é moldada in loco utilizando um conjunto de trados segmentados os quais penetram no solo através de rotação combinada carga vertical aplicada por um cilindro hidráulico com empuxo axial de $70 \mathrm{kN}$ durante a fase de instalação da hélice (pull-down) e $150 \mathrm{kN}$ durante a fase de extração da mesma (pullback).

Atingida a cota de parada da estaca, a injeção de argamassa é feita através do tubo central utilizando-se uma bomba apropriada. A extração do trado é feita em conjunto com a injeção de argamassa.

O monitoramento das pressões de injeção é conseguido com a utilização de um manômetro especificado para medir pressões em meios abrasivos. Esse instrumento possibilita a manutenção de pressões manométricas maiores que zero, durante todo o processo de injeção. O termo “pressão positiva” já é comum entre os especialistas em estaca hélice contínua, quando se deseja mencionar pressão manométrica maior que zero. Pressões entre 50 e 200 kPa são comuns durante o processo de injeção.

Um segmento de 1,50 m (ponteira) e um trado segmentado de 3,50 m ficam constantemente instalados na posição de trabalho, ou seja, concêntricos com o eixo do cabeçote rotativo. Três segmentos de $3,50 \mathrm{~m}$ ficam alojados em um conjunto denominado “alimentador” o qual é responsável pela mecanização das emendas.

Apresenta-se a seguir a metodologia executiva de uma estaca hélice segmentada.

\subsection{FASE DE ESCAVAÇÃO}

Posiciona-se o equipamento com a torre no prumo e com a ponteira aproximadamente 0,20 m acima do piquete que indica o eixo da estaca (Figura 4.1). 
Nessa posição a haste do cilindro de empuxo axial está totalmente estendida e o cabeçote rotativo encontra-se na posição mais elevada possível. A composição formada pelo cabeçote rotativo, pela haste telescópica (prolonga) com a haste interna totalmente recolhida, por um módulo de hélice (3,5 m) e por um segmento de 1,50 (ponteira) foi projetada de modo que com o abaixamento de $0,20 \mathrm{~m}$ do cabeçote, a ponteira toca $\mathrm{o}$ solo.

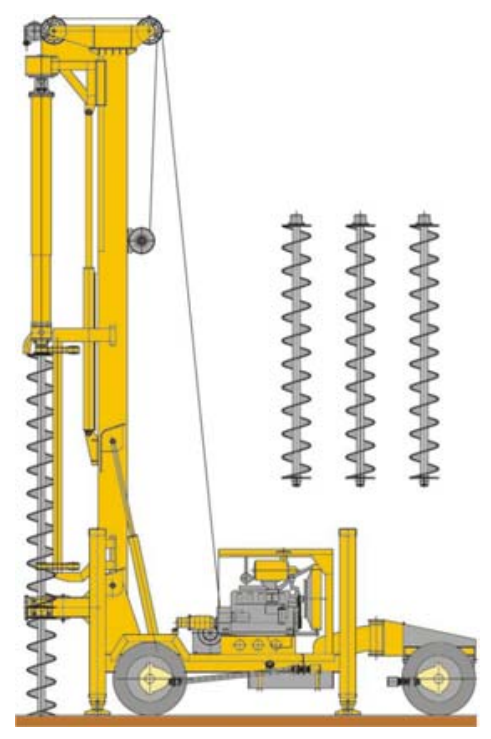

Figura 4.1 - Posição de início da escavação da estaca.

Nessa condição os três segmentos de 3,50 m estão alojados no alimentador de segmentos. Em seguida inicia-se o processo de escavação acionando-se simultaneamente o cabeçote rotativo e o cilindro de empuxo axial (pull-down) até que ocorra um avanço de 2,0 m que corresponde ao curso do cilindro. Nesse momento o movimento de rotação do cabeçote é paralisado e um giro no sentido anti-horário de aproximadamente $90^{\circ}$ destrava a haste interna do conjunto de hastes telescópicas e a haste externa é movimentada para cima com o acionamento do cilindro de empuxo axial que novamente passa a ter sua haste estendida. O cabeçote rotativo é novamente acionado no sentido horário em conjunto com o cilindro de empuxo axial promovendo a continuidade da escavação até completar 3,50 m de profundidade (Figura 4.2).

Os cilindros hidráulicos da morsa são acionados e prendem a hélice para que o acoplamento com rosca cônica que liga o cabeçote ao trado possa ser liberado da hélice e o cabeçote rotativo levado novamente para cima para que um espaço um pouco maior que 3,50 m entre a parte superior da hélice e a parte inferior do cabeçote possibilite a 
colocação na posição de trabalho, de um dos trados segmentados que estão alojados no alimentador.

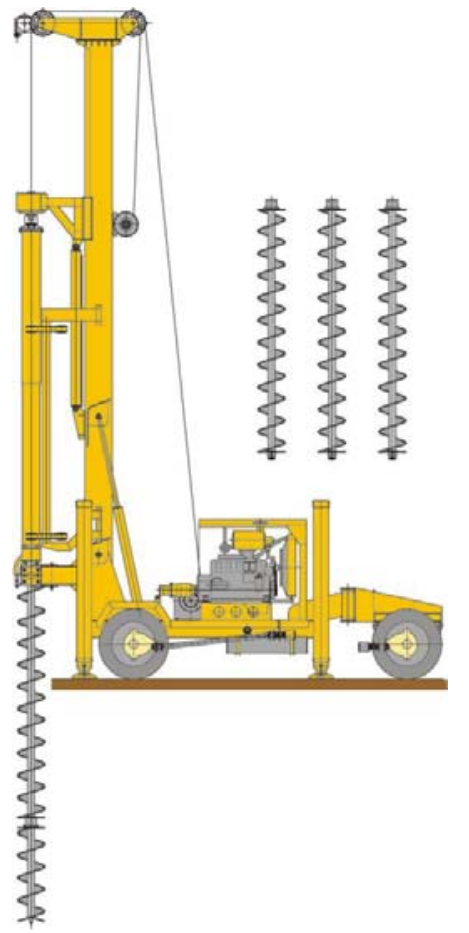

Figura 4.2 - Fase de escavação com instalação da ponteira e parte do trado segmentado.

O processo de avanço se repete para a instalação do próximo segmento (Figura 5.3).

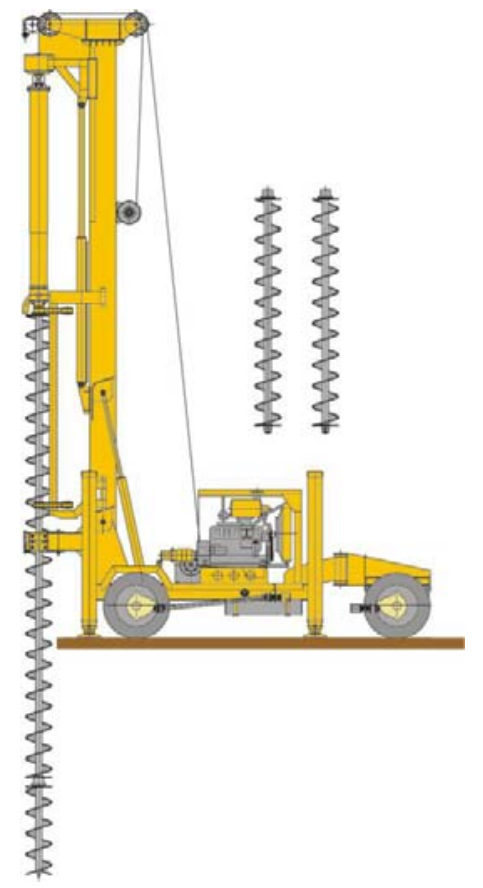

Figura 4.3 - Fase de instalação da hélice com a colocação de um segmento de trado do alimentador para a posição de trabalho. 
O processo de avanço continua até se atingir a cota de parada da estaca.

\subsection{FASE DE EXTRAÇÃO DA HÉLICE}

Atingida a cota de parada da escavação a composição é levantada aproximadamente 0,20 m para que a argamassa a ser injetada sob pressão possa expulsar a tampa da extremidade inferior do tubo central da hélice.

O processo de extração é iniciado simultaneamente à injeção de argamassa, desde que o manômetro utilizado indique pressões dentro da faixa de pressões préestabelecidas (Figura 4.4).

As hélices segmentadas vão sendo retiradas monitorando-se as pressões de injeção até que a ponteira volte a se posicionar acima da superfície do solo, indicando que toda a estacas foi preenchida pela argamassa (Figura 4.5).

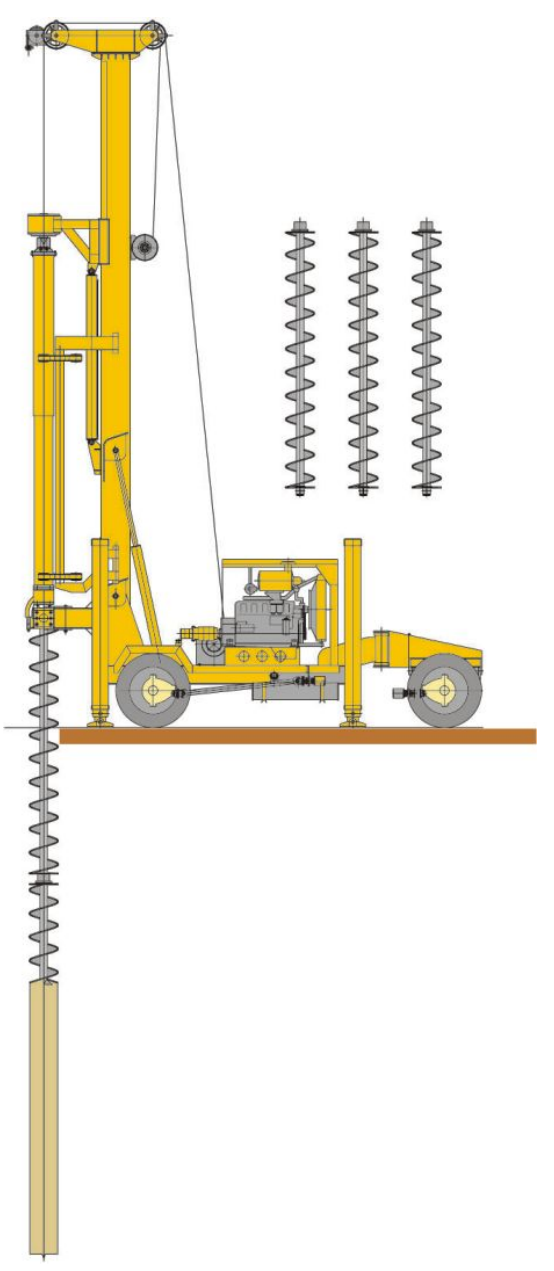

Figura 4.4 - Fase de extração do primeiro segmento de hélice. 


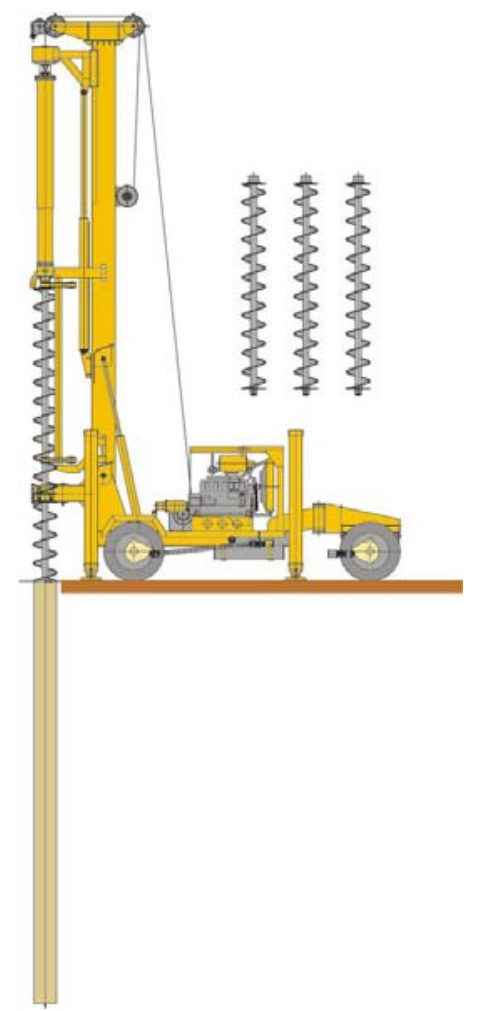

Figura 4.5 - Fase de extração com término da estaca.

Durante a fase de escavação um ajudante é suficiente para a remoção do material escavado que foi transportado para a superfície. O volume desse material é pequeno, já que o solo fica envolvido na hélice e será retirado na fase de extração (Figura 4.6).

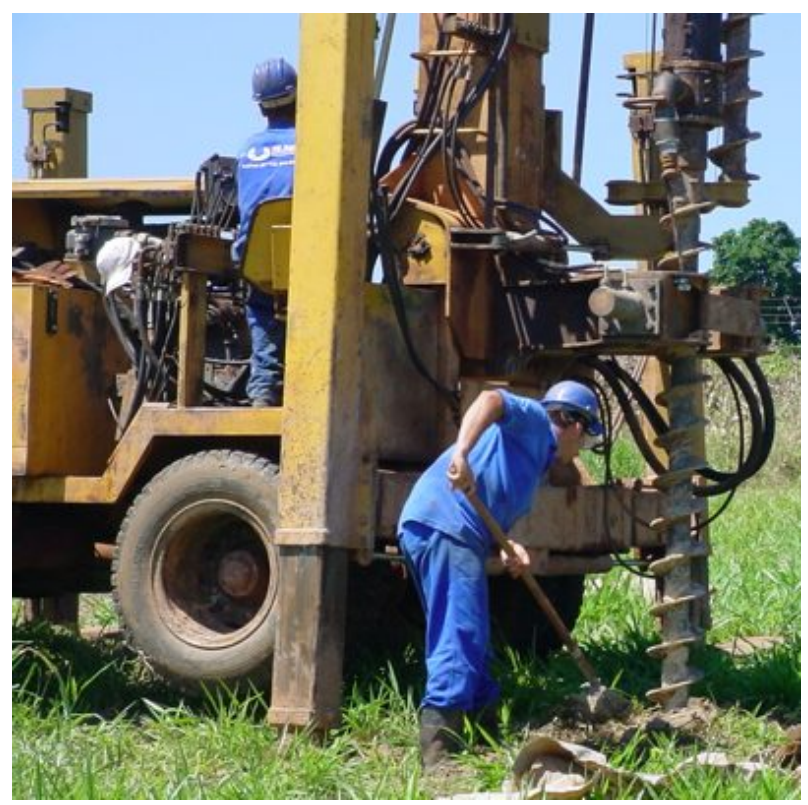

Figura 4.6 - Fase de escavação de uma estaca. 
Como o processo é relativamente lento, na fase de extração da hélice um ajudante também é suficiente para a limpeza do solo envolvido na hélice.

Durante a fase de extração é importante observar se os segmentos de trados apresentam-se com os espaços da hélice totalmente preenchidos pelo solo, já que essa é uma condição necessária para que não haja desconfinamento do solo circundante à estaca (Figura 4.7). É importante que a injeção de argamassa seja feita até o final da extração da hélice para garantir a continuidade do fuste da estaca até a superfície do terreno. Portanto, não se deve estabelecer cota de arrasamento abaixo da superfície do solo (Figura 4.8).

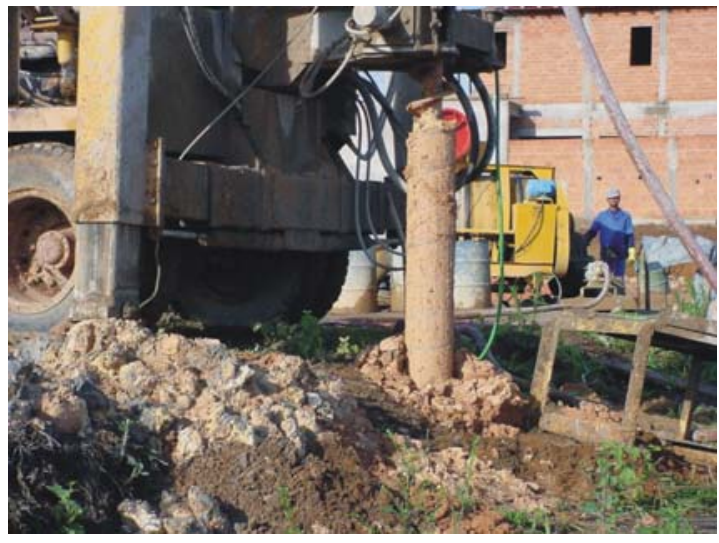

Figura 4.7 - Fase de extração da hélice com visualização do confinamento do solo.

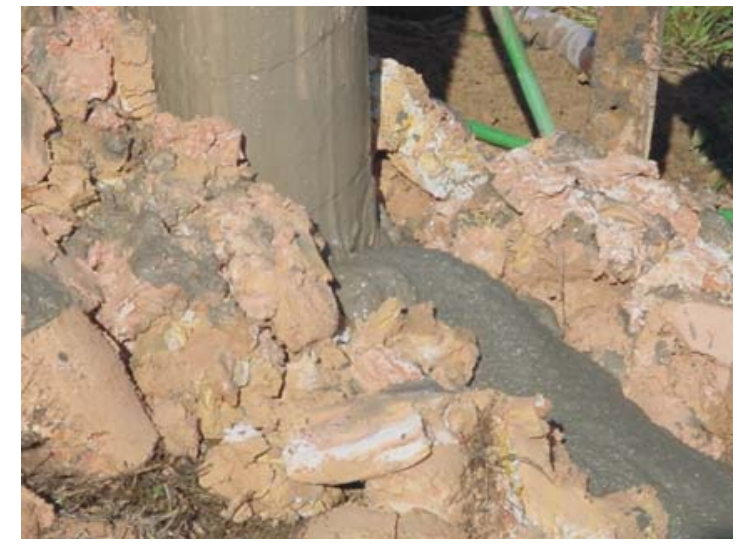

Figura 4.8 - Vista da expulsão de argamassa no final da extração da hélice.

Logo após a extração da hélice a torre do equipamento é colocada na posição horizontal ou com pequena inclinação em relação à horizontal (Figura 4.9), acionandose os dois cilindros hidráulicos de giro da torre. As manobras necessárias para o posicionamento na próxima estaca são feitas utilizando-se o sistema de tração disponível na perfuratriz. 


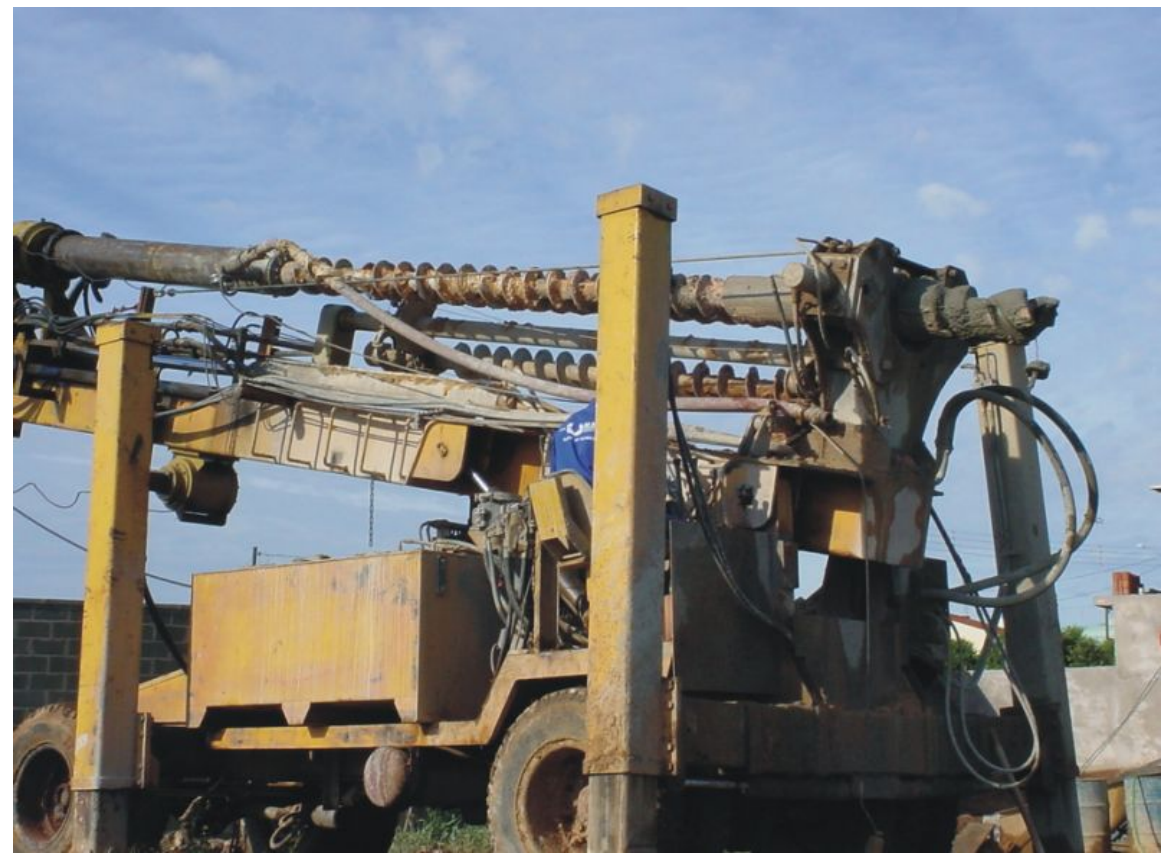

Figura 4.9 - Torre sendo posicionada na horizontal para a manobra do equipamento para outra estaca. 


\section{CAPÍTULO 5}

\section{EQUIPE DE COLABORADORES E EQUIPAMENTOS DE APOIO UTILIZADOS NA EXECUÇÃO DAS ESTACAS}

Além da fundamental participação da equipe de colaboradores, durante a execução das estacas são necessários equipamentos e acessórios que em conjunto com a perfuratriz, viabilizam a materialização das estacas. A seguir descrevem-se os itens mais importantes, de modo resumido.

\subsection{EQUIPE DE COLABORADORES}

Sabe-se que a participação do homem é de vital importância na maior parte de todos os bens que são por ele construídos. No presente trabalho, constatou-se que o pessoal envolvido na execução das estacas constituiu-se, sem nenhuma dúvida, no item de maior importância em todo o processo de execução das estacas.

Ao operador da perfuratriz compete:

a) Carregar e descarregar o equipamento com atenção, para que esta operação possa ser feita de forma segura.

b) Verificar os itens básicos do equipamento tais como:

- Nível de óleo do motor diesel.

- Nível de óleo do reservatório hidráulico.

- Vazamentos no sistema hidráulico.

- Nível de água do radiador do motor diesel.

- Temperatura do motor diesel durante a operação da perfuratriz.

- Temperatura do óleo hidráulico.

- Pressões nos pneus da perfuratriz.

- Condições gerais do equipamento (limpeza, pintura, etc).

c) Verificar as condições de segurança do terreno da obra tais como declividades, aterros, interferências aéreas, etc. 
d) Verificar se a locação foi feita com piquetes de material que não danifique os pneus da perfuratriz e que estejam cravados no solo de forma que não saia da posição locada caso a perfuratriz passe por cima dos mesmos. Os piquetes devem ficar no mesmo nível da superfície do solo ou alguns centímetros abaixo.

e) Verificar se o projeto das fundações está disponível no canteiro de obras.

f) Verificar se existe alguém da parte do cliente que possa liberar o início dos serviços e acompanhar a execução dos mesmos.

g) Preencher corretamente os boletins diários de obra, com todas as informações sobre as ocorrências, além das anotações normais tais como: identificação da estaca com seu respectivo diâmetro e comprimento.

h) Ser calmo, sem ser lento na operação do equipamento e ter consciência das responsabilidades que a empresa executora tem com relação à qualidade dos serviços executados.

i) Observar com muito rigor as pressões de injeção de argamassa ou concreto, durante toda a fase de extração da hélice segmentada, já que o monitoramento não fica registrado para posterior conferência das pressões de injeção.

j) Comunicar imediatamente ao engenheiro da empresa executora e ao engenheiro da obra qualquer ocorrência que não seja normal durante o processo de execução de determinada estaca.

k) Impedir que pessoas estranhas ou não treinadas se aproximem do equipamento em operação ou na fase de carregamento e descarregamento.

l) Nunca posicionar o equipamento nem aproximar ferramentas ou qualquer material de trabalho aos fios de alta tensão a distâncias inferiores a 3 metros, exceto quando a energia for cortada por pessoal habilitado da concessionária local de energia elétrica.

Ao engenheiro da empresa executora das fundações compete:

a) Verificar as condições de segurança do terreno da obra tais como declividades, aterros, interferências aéreas, etc. juntamente com o operador da perfuratriz.

b) Verificar se o projeto das fundações está disponível no canteiro de obras.

c) Verificar em conjunto com o operador, se existe alguém da parte do cliente que possa liberar o início dos serviços e acompanhar a execução dos mesmos.

d) Acompanhar o preenchimento dos boletins diários de obra, elaborados pelo operador ou trazer para si esta função caso seja residente na obra. 
e) Manter um diálogo saudável e proveitoso com o engenheiro da obra, com o engenheiro projetista e com os demais profissionais envolvidos para que os serviços sejam executados da melhor forma possível.

f) Conhecer perfeitamente o processo executivo da estaca.

g) Verificar, sempre que possível, as condições gerais dos equipamentos e acessórios envolvidos no processo de execução da estaca.

h) Fiscalizar e auxiliar no que for necessário os colegas envolvidos na obra de fundação.

Ao responsável pela execução da argamassa cabe:

a) Verificar as condições gerais do misturador e da bomba de argamassa mantendoos limpos e fazendo a manutenção básica.

b) Medir corretamente as quantidades dos materiais envolvidos no processo, conforme as orientações do engenheiro da empresa executora.

c) Colher corpos de prova para ensaios de resistência conforme as orientações do engenheiro da empresa executora ou do engenheiro da obra.

d) Conhecer perfeitamente o processo de execução da argamassa de cimento.

e) Cuidar em conjunto com o ajudante para que a bomba e mangueiras fiquem sempre limpos, de forma a evitar o entupimento da rede de injeção.

Ao servente da empresa executora das fundações cabe:

a) Ajudar na manutenção básica dos equipamentos, acessórios e ferramentas envolvidos no processo.

b) Manter limpos os equipamentos, acessórios e ferramentas.

c) Executar os serviços de limpeza do solo das hélices segmentadas durante a fase de extração das mesmas.

d) Executar as operações de colocação e retirada dos pinos de emendas dos trados segmentados.

e) Auxiliar nas diversas atividades necessárias à execução da obra sempre que solicitadas pelo operador ou pelo engenheiro de fundações da parte da empresa executora.

Observa-se pelo exposto acima, a importância dos quatro colaboradores na execução das fundações de uma obra, mesmo dispondo-se de um equipamento mecanizado. 


\subsection{MISTURADOR DE ARGAMASSA}

A argamassa de cimento pode ser produzida na obra ou em uma usina. Quando preparada na obra pode-se utilizar um misturador (Figura 5.1) ou uma betoneira comum ou ainda uma betoneira rotativa. No presente trabalho utilizou-se uma betoneira rotativa (Figura 5.2) com capacidade de $0,50 \mathrm{~m}^{3}$, acionada por um motor elétrico trifásico de 7,4 kW (10 CV) com tensão de 220 V ou 380 V. O misturador mostrado na Figura 5.1 é equipado com um mecanismo excêntrico que possibilita excelente homogeneização da argamassa (Figuras 5.3 e 5.4).

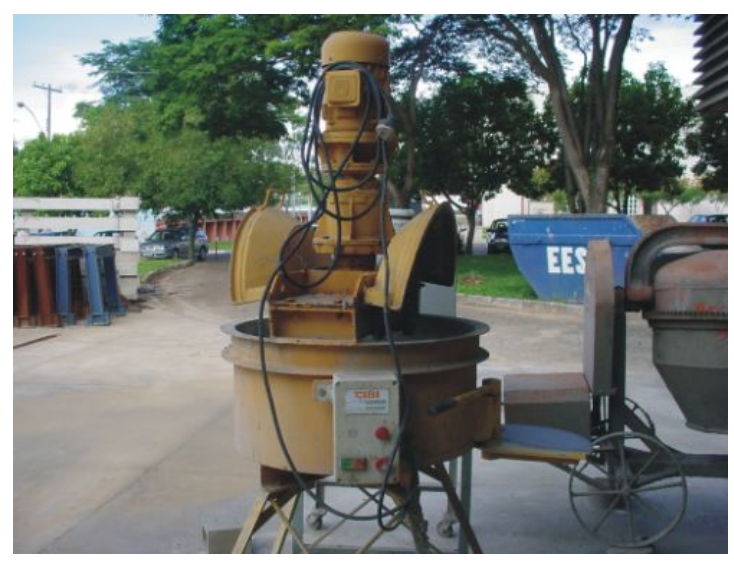

Figura 5.1 - Misturador planetário CIBI

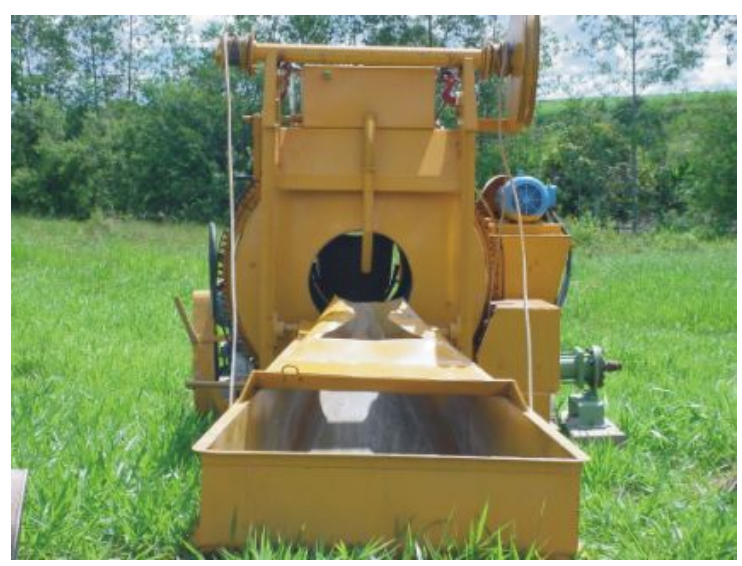

Figura 5.2 - Betoneira rotativa para 500 l.

Os misturadores mais simples, os quais tem as pás concêntricas com o eixo da caçamba do misturador, são os mais utilizados pelas empresas que executam estacas do tipo RAIZ (Figura 5.5).

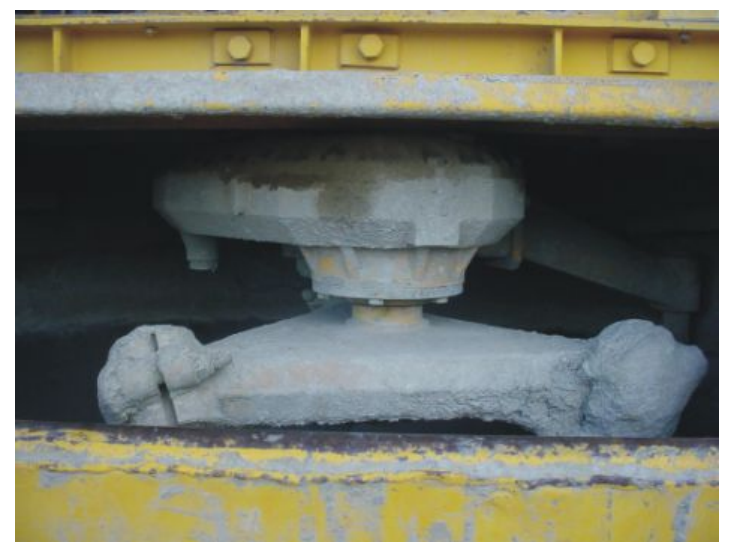

Figura 5.3 - Vista do sistema planetário no interior da caçamba do misturador marca CIBI.

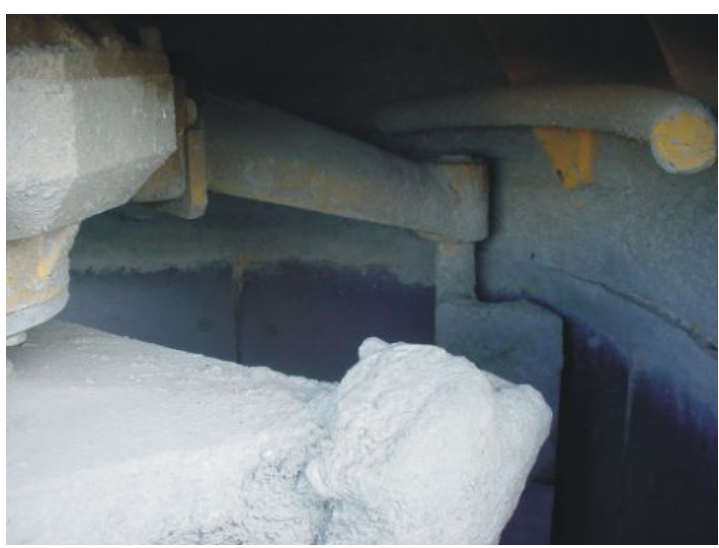

Figura 5.4 - Vista de uma pá do misturador planetário CIBI. 


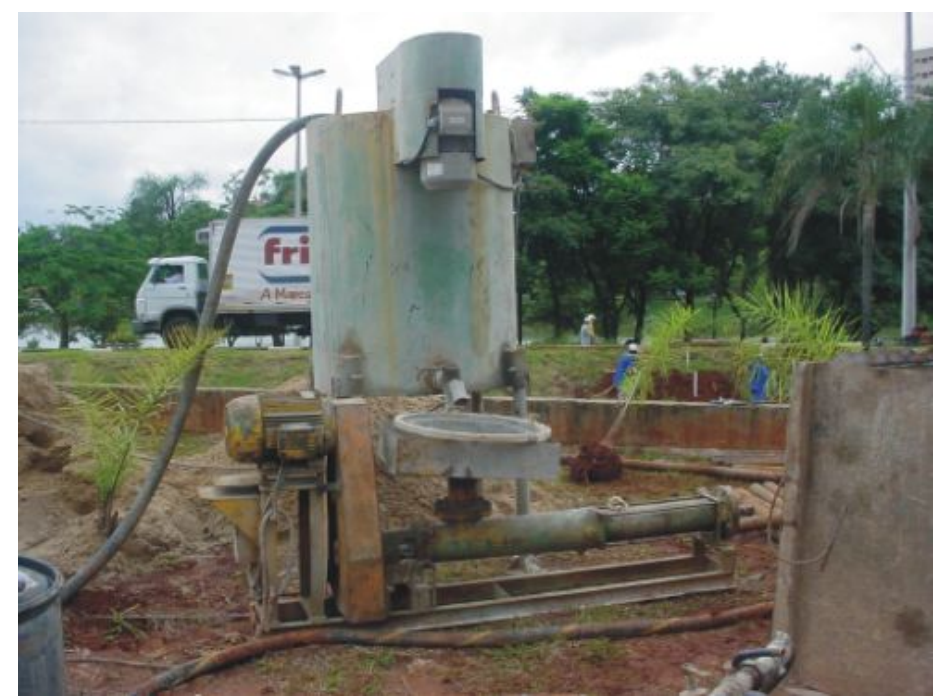

Figura 5.5 - Misturador com eixo de giro das pás concêntrico em relação à caçamba do misturador.

\subsection{BOMBA DE ARGAMASSA}

Este equipamento é basicamente composto de um motor elétrico, um conjunto de polias que reduzem a rotação e aumentam o torque no eixo da bomba, uma caixa feita de chapas onde a argamassa produzida no misturador é lançada, uma rosca transportadora com aproximadamente $300 \mathrm{~mm}$ de comprimento, uma estrutura metálica, um estator de borracha moldado em um tubo de aço e um rotor em aço liga tratado termicamente (Figura 5.6).

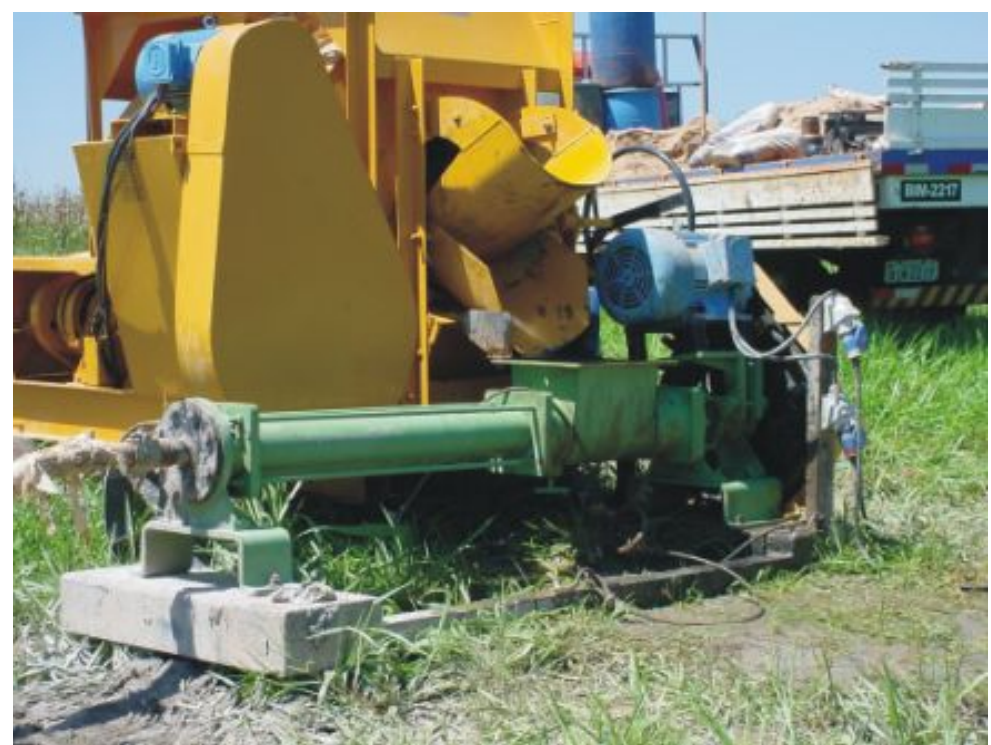

Figura 5.6 - Vista da bomba de argamassa e betoneira utilizadas nas estacas executadas, para posterior extração.

A areia utilizada não deve conter partículas maiores que 2,0 mm, para que a possibilidade de travamento do rotor da bomba seja minimizado, evitando a paralisação 
da injeção de argamassa. Por isso é conveniente executar o peneiramento de toda a areia fornecida na obra, com utilização de uma peneira \# 10.

Em geral as bombas de argamassa não devem permanecer paradas por um período maior que 15 minutos sem serem lavadas com água limpa. Deve-se proceder à lavagem da bomba até que a água saia completamente limpa em seu bocal de saída.

\subsection{MANGUEIRAS E TERMINAIS}

As mangueiras utilizadas para o transporte da argamassa devem ter diâmetros internos maiores que $38 \mathrm{~mm}$, não havendo vantagens práticas no uso de mangueiras com diâmetros internos maiores que $50 \mathrm{~mm}$.

A utilização de mangueiras longas tem a vantagem da economia de emendas (terminais), no entanto, tem a grande desvantagem da dificuldade de limpeza quando a mesma é feita já no início da cura da argamassa. No início dos testes foram utilizadas apenas duas mangueiras sendo uma de $6 \mathrm{~m}$ e outra de $12 \mathrm{~m}$. Posteriormente optou-se pela utilização de mangueiras com comprimento máximo de $6 \mathrm{~m}$ o que se mostrou mais prático não só quanto à questão da limpeza interna, mas também com relação à maior facilidade nas movimentações das mesmas na obra.

Com relação às emendas optou-se pela utilização de terminais com engates rápidos, que são normalmente utilizados em conjunto com os equipamentos e acessórios utilizados na execução das estacas do tipo raiz.

\subsection{OUTROS EQUIPAMENTOS E ACESSÓRIOS}

Além dos equipamentos descritos resumidamente acima, para a execução das estacas hélice segmentada são necessários os seguintes itens de apoio:

a) Guincho hidráulico montado sobre caminhão com capacidade de elevação mínima de 30 kNm.

b) Pá.

c) Enxada.

d) Marreta de $5 \mathrm{~kg}$.

e) Carriolas.

f) Baldes de $20 \mathrm{l}$.

g) Peneira \# 10.

h) Caixa com ferramentas básicas ( chaves de fendas, alicate, grifo, etc). 
i) Fita isolante.

\subsection{SEGURANÇA NO TRABALHO}

No passado, muitos acidentes poderiam ter sido evitados se as empresas tivessem desenvolvido e implementado programas de segurança e saúde no trabalho.

Atualmente, entre as normas regulamentadoras de segurança e saúde no trabalho, a NR 18 é a que trata das condições e meio ambiente de trabalho na indústria da construção. Em seu item 18.3 estão os requisitos a serem seguidos para a elaboração e cumprimento do PCMAT (Programa de Condições e Meio Ambiente do Trabalho na Indústria da Construção). Esse programa tem como objetivo:

a) Garantir a saúde e a integridade dos trabalhadores.

b) Definir atribuições, responsabilidades e autoridade ao pessoal que administra, desempenha e verifica as atividades que influem na segurança e que intervêm no processo produtivo.

c) Fazer a previsão dos riscos que derivam do processo de execução da obra.

d) Determinar as medidas de proteção e prevenção que evitem ações e situações de risco.

e) Aplicar técnicas de execução que reduzam ao máximo possível esses riscos de acidentes e doenças.

O PCMAT deve contemplar as exigências contidas na NR 9 - Programa de Prevenção e Riscos Ambientais (PPRA), pois para que as ações de melhoria das condições do ambiente de trabalho sejam implantadas é necessário conhecer os riscos provocados por agentes físicos, químicos e agentes biológicos.

Esses programas devem ser elaborados por profissionais especializados em engenharia de segurança e em medicina do trabalho (SESMT).

Apresenta-se a seguir orientações que poderão contribuir para a prevenção de acidentes no trabalho, não só quando da utilização do equipamento desenvolvido, como também de uma forma geral nas obras de construção civil:

a) Cada funcionário deve executar o seu serviço de forma a promover não só a sua segurança como também a de seus colegas de trabalho. 
b) Todas as pessoas envolvidas na obra devem pensar na segurança, portanto, qualquer observação de algo que possa constituir-se em risco de acidente deve ser imediatamente comunicado ao seu chefe ou ao responsável pela obra.

c) Fazer uso dos equipamentos de proteção individual (EPI's), que forem especificados pelo seu superiror. Os EPI’s mais comuns são: óculos de segurança, luvas, capacete, botas com biqueira de aço, protetor auricular e cinto de segurança.

d) Não utilizar chaves abertas ou gastas, pois uma chave que quebra ou escapa pode provocar um acidente em você ou nos seus colegas.

e) Um homem só não deve levantar com freqüência, cargas superiores a $550 \mathrm{~N}$. Para levantar uma carga, deve-se encolher as pernas mantendo o corpo o mais direito possível. Para levantá-la, utilizar somente os músculos das pernas, evitando flexão da coluna vertebral.

f) Cargas compridas e flexíveis como barras de aço, por exemplo, não devem ser transportadas de um local para outro da obra por um só homem. Os balanços e a flexibilidade da carga podem provocar acidente.

g) Todo trabalho em grupo deve ser planejado e coordenado por uma única pessoa, via de regra um chefe. Esse procedimento permite que o trabalho em conjunto se torne mais eficiente e seguro.

h) Deverá ser assegurado que cada funcionário esteja treinado para o correto desempenho de suas funções.

i) Todos os funcionários deverão estar cientes que a violação das normas de segurança constitui falte grave, suscetível à dispensa por justa causa.

j) Não devem ser permitidas brincadeiras ou discussões nos locais de trabalho, pois elas poderão implicar em falta de concentração na atividade que está sendo exercida, provocando acidentes.

k) A ingestão de bebidas alcoólicas ou drogas nunca deve ser permitida antes ou durante a jornada de trabalho.

l) Sempre devem ser respeitadas as normas de segurança de cada empresa contratante dos serviços.

m) Relógios de pulso, braceletes, roupas folgadas, anéis, correntes, etc, nunca devem ser utilizados durante o trabalho.

n) Jatos de ar comprimido ou água, nunca devem ser dirigidos contra si próprio ou contra outras pessoas, mesmo com o intuito de limpar ou secar. 
o) Não correr nas dependências da obra.

p) Trabalhar sempre com calçado adequado à atividade que está sendo exercida e às condições do local. Nunca trabalhar descalço ou de chinelos.

q) Isolar as áreas de risco com utilização de cordas, cones, etc.

r) Não jogar ferramentas ou materiais para um colega, passe-os de suas mãos para as dele.

s) O trabalho com cabos ou cordas exige sempre luvas.

t) Não transportar pessoas em aparelhos de elevação de cargas.

u) Antes de iniciar qualquer escavação deve-se ter conhecimento de possíveis interferências tais como canalizações, redes elétricas, galerias, etc. 


\section{CAPÍTULO 6}

\section{EXTRAÇÃO DE ESTACAS}

\subsection{CONSIDERAÇÕES GERAIS}

Com a finalidade de verificar a integridade dos fustes das estacas, foram executadas duas estacas hélice segmentada ( $E_{1}$ e $E_{2}$ ), com diâmetro nominal de $25 \mathrm{~cm}$, em área rural do município de Araras-SP (no sítio São José, bairro Caio Prado, de propriedade do Sr. Osni Zaniboni). Executou-se um furo de sondagem de simples reconhecimento do solo (SPT) de acordo com a norma NBR 6484/2001 (Figura 6.1).

Como pode ser observado no relatório de sondagem executada, o subsolo local apresentou uma camada de 0,80 $\mathrm{m}$ de areia fina argilosa marrom com manchas pretas, com presença de material vegetal e uma camada de 0,80 a 7,60 m de areia fina siltosa, pouco argilosa, fofa a medianamente compacta. A boca do furo de sondagem estava na cota 100,37 m e a investigação foi paralisada na cota 92,77 m, considerando como 100,00 m o RN adotado na face superior de um marco de concreto colocado próximo de um poste de energia elétrica.

A Figura 6.2 apresenta uma planta de locação do furo de sondagem e das estacas executadas.

O nível do lençol freático estabilizou-se na cota 99,77 m em relação ao RN adotado, que corresponde à profundidade de 0,60 m em relação à boca do furo de sondagem.

A sondagem foi dada por encerrada na cota 92,77 m devido à impossibilidade de avanço pelo processo de avanço por lavagem conforme recomenda a norma brasileira NBR 6484/2001. Por outro lado, tendo em vista a presença de água próximo à superfície e solo de baixa resistência, o local mostrou-se adequado à verificação da integridade dos fustes das estacas executadas, efetuando-se a extração das mesmas. Não era o caso de se executar estacas mais profundas já que não se dispunha de equipamentos adequados para a extração de estacas mais longas, e além disso, o objetivo da dissertação foi o 
desenvolvimento do equipamento para a execução de estacas e não a realização de provas de carga em estacas.

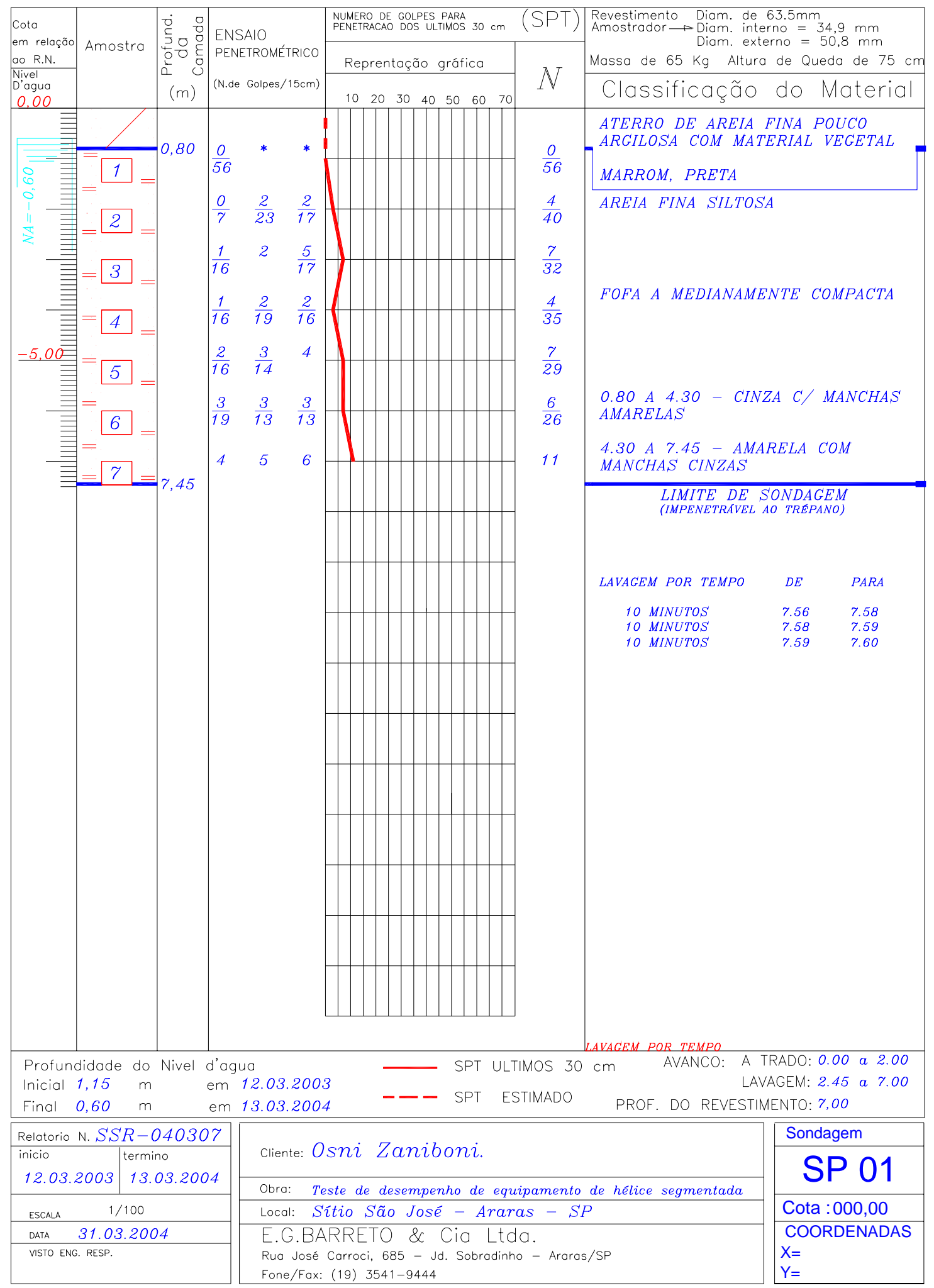

Figura 6.1 - Relatório de um furo de sondagem (SPT). 


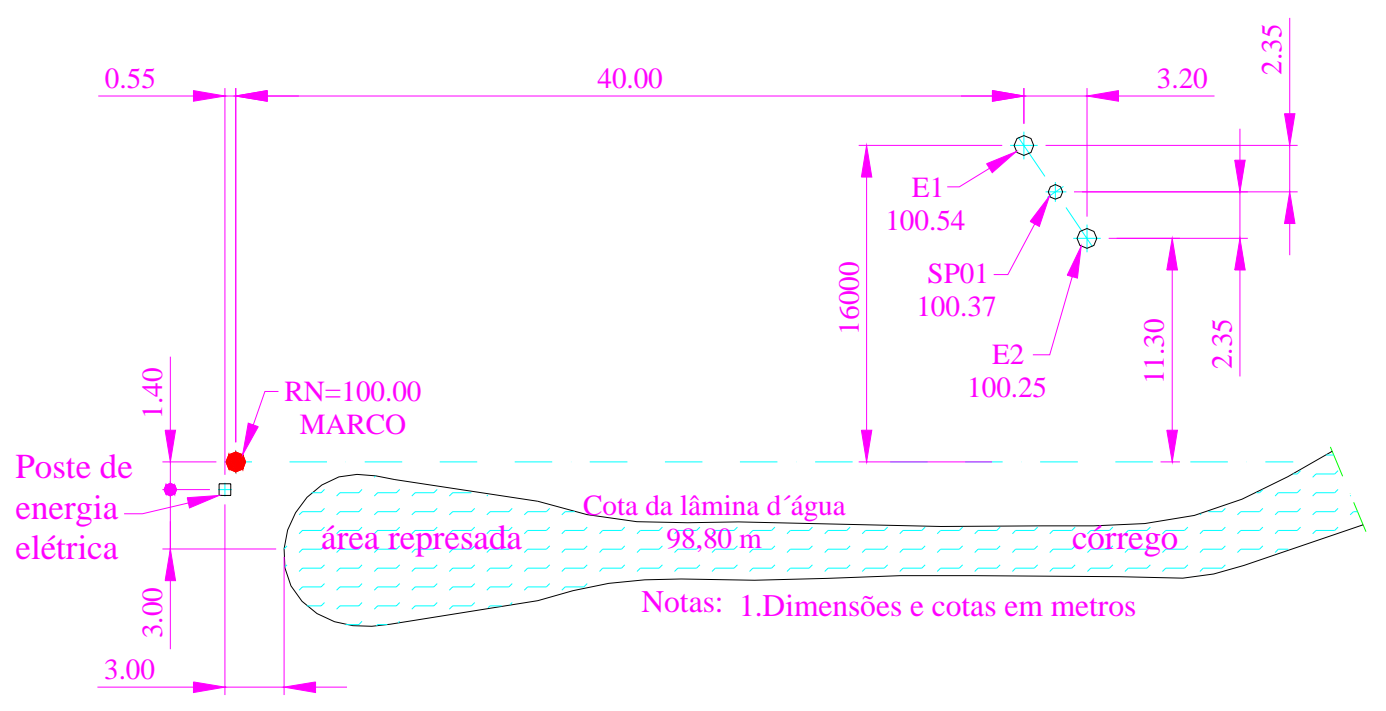

Figura 6.2 - Locação do furo de sondagem e das estacas $E_{1}$ e $E_{2}$.

A estaca $E_{1}$ teve a ponta assentada aproximadamente na cota 94,54 m e a injeção foi feita até a superfície do terreno. A ponta da estaca $E_{2}$ ficou aproximadamente na cota 94,25 m e a injeção foi paralisada na cota 97,25 m.

\subsection{TENTATIVA INICIAL DE EXTRAÇÃO DAS ESTACAS}

Após 8 dias da execução das estacas, tentou-se a extração da estaca $E_{1}$ utilizando-se um cilindro hidráulico com curso de 1,00 m, diâmetro interno de camisa de 88,9 mm, diâmetro externo da camisa de 101,6 mm e diâmetro da haste de 50,80 mm. O cilindro foi montado numa estrutura metálica composta por 4 tubos com diâmetro externo de 113,50 mm, diâmetro interno de 105,00 mm (norma DIN 2440) e comprimento de 4,50 m (Figura 6.3).

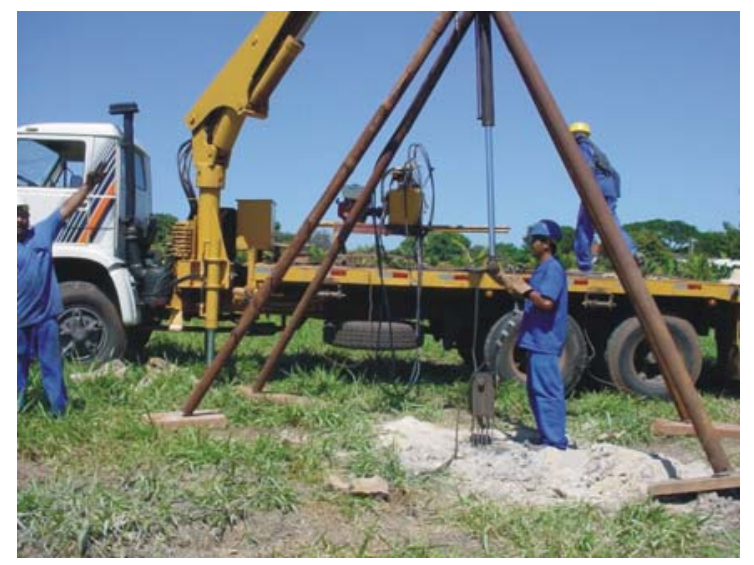

Figura 6.3 - Tentativa de extração de uma estaca com utilização de um cilindro hidráulico. 
Utilizou-se uma unidade hidráulica (Figura 6.4), composta de um motor a gasolina de 5,90 kW (8,0 CV), uma bomba hidráulica de engrenagens que fornece uma vazão (Q) de aproximadamente 20 l/min a 1800 rpm e pressão máxima de trabalho (pmáx) de 20 MPa (200 bar).

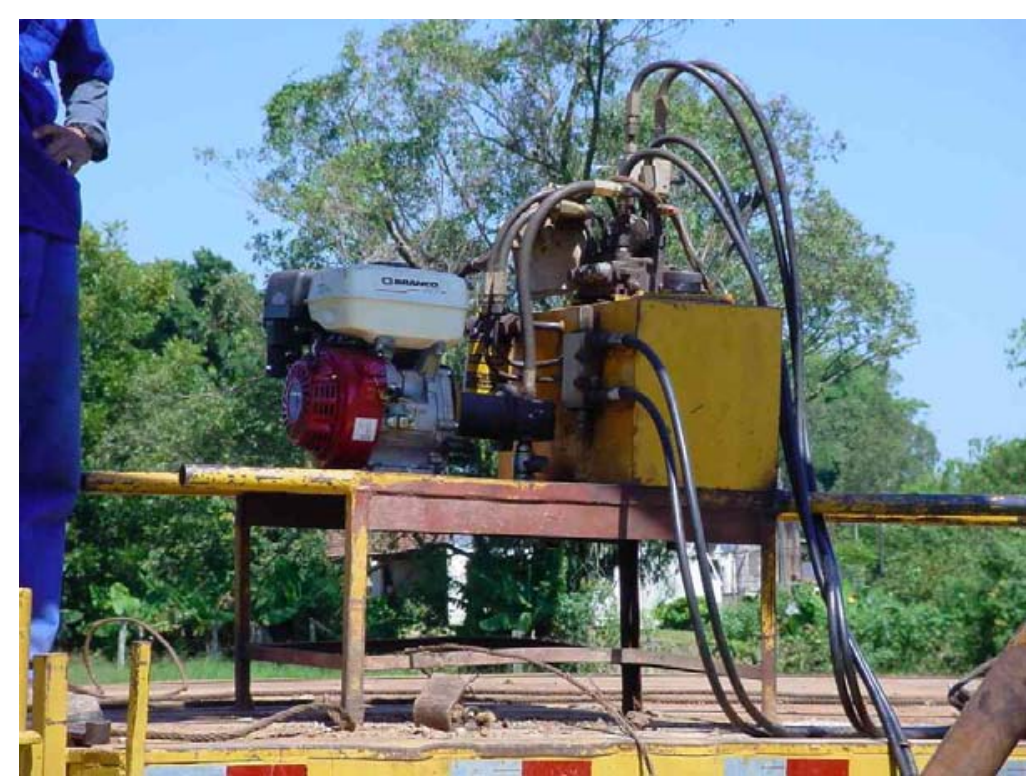

Figura 6.4 - Unidade hidráulica utilizada para acionamento do cilindro.

Tendo em vista que o cilindro foi montado na vertical e com a haste para baixo, a área a considerada no cálculo da força de extração foi igual à diferença entre a área da camisa e a área da seção transversal da haste do cilindro. Nesse caso tem-se:

$F_{h}=-\left(A_{c a}-A_{h}\right) \times p$

em que:

$F_{h}=$ Força na haste do cilindro em $\mathrm{kN}$.

$A_{c a}=$ Área da camisa do cilindro em $\mathrm{m}^{2}$.

$A_{h}=\quad$ Área da haste do cilindro em $\mathrm{m}^{2}$.

$p=\quad$ Pressão hidráulica em kPa.

Convencionou-se que o sinal negativo indica tração na haste do cilindro, já que a situação mais comum na prática é que as hastes de cilindros hidráulicos trabalhem em compressão. 
A força de tração na haste do cilindro, desprezadas as perdas nas mangueiras, foi:

$F_{h}=-((6,21 \mathrm{E}-3)-(2,03 \mathrm{E}-3)) \times 20000=-83,6 \mathrm{kN}$

Para essa força de extração, nenhum deslocamento da cabeça da estaca foi observado a olho nu.

\subsection{ESCAVAÇÃO DO SOLO CIRCUNDANTE ÀS ESTACAS}

Tendo em vista que a tentativa de extração da estaca $E_{1}$ com utilização do cilindro e da unidade hidráulica disponíveis não teve êxito, decidiu-se executar escavações mecanizadas em volta das estacas de forma a promover o desconfinamento do solo circundante (Figuras 6.5, 6.6 e 6.7).

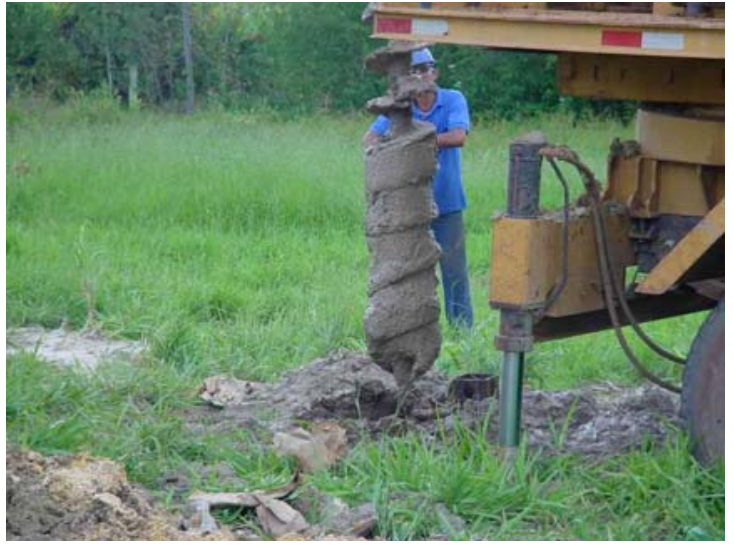

Figura 6.5 - Fase inicial da escavação mecanizada do solo circundante à estaca.

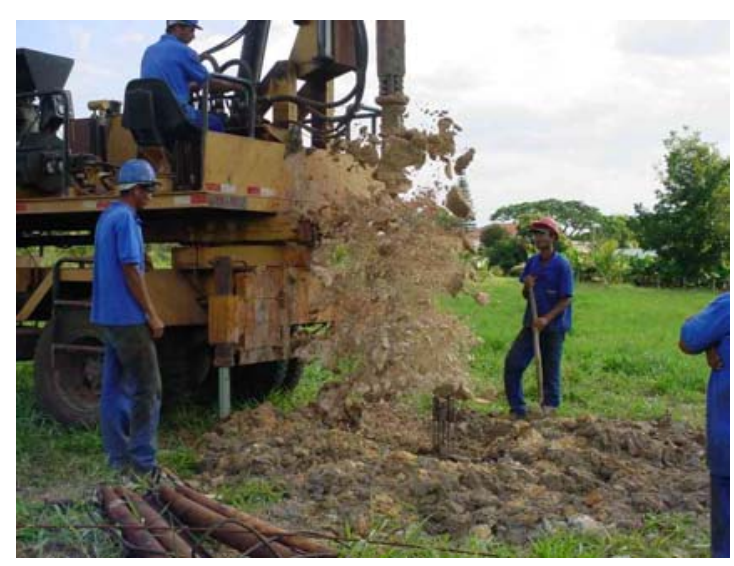

Figura 6.6 - Fase intermediária da escavação mecanizada do solo circundante à estaca.

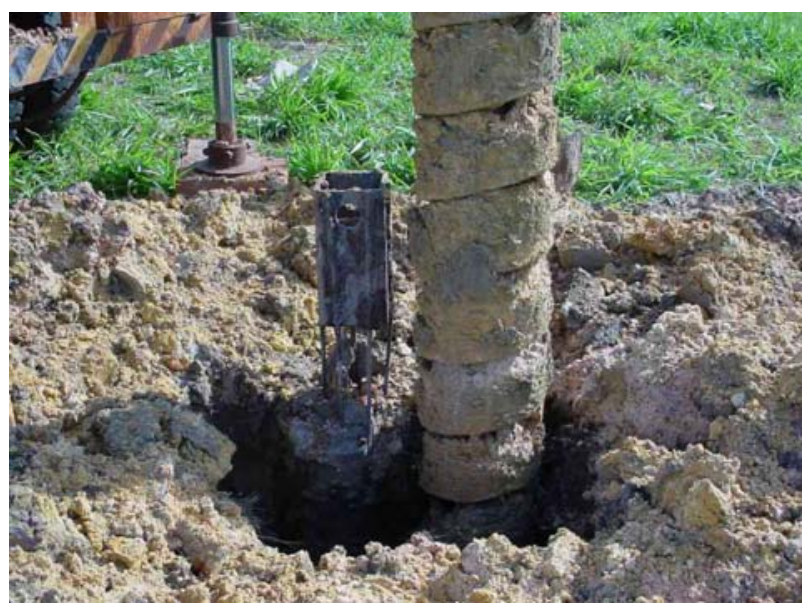

Figura 6.7 - Fase final da escavação mecanizada do solo circundante à estaca. 
Imediatamente após as escavações realizadas no contorno da estaca, a extração foi possível com a utilização de um guincho de $120 \mathrm{kNm}$. A primeira estaca extraída foi a $\mathrm{E}_{1}$ (Figura 6.8) e a segunda foi a $\mathrm{E}_{2}$ (Figura 6.9).

Para cada estaca foi providenciada uma armadura longitudinal composta de quatro barras $\phi 10 \mathrm{~mm}$ CA-50 com comprimento de 6,0 m, com estribos $\phi 5 \mathrm{~mm}$ CA-60 espaçados de $15 \mathrm{~cm}$.

$\mathrm{Na}$ estaca $\mathrm{E}_{1}$ a armadura penetrou apenas $3 \mathrm{~m}$ na argamassa e $3 \mathrm{~m}$ ficaram para fora da estaca. A solução dada foi instalar uma barra de 12,5 mm com comprimento de $6 \mathrm{~m}$ no centro da estaca para que a mesma pudesse ser posteriormente tracionada.

Quanto à estaca $E_{2}$ a injeção não foi feita até a superfície do terreno para que a armadura pudesse ser inserida até a ponta da estaca.

Mesmo com as escavações mecanizadas realizadas em volta das estacas o guincho hidráulico utilizado não obteve sucesso na primeira tentativa de extração da estaca $E_{1}$. A solução adotada foi aplicar esforços horizontais com um movimento de “vai-e-vem” do braço mecânico do guincho, combinados com esforços de tração. Dessa forma foi possível ter sucesso na extração, no entanto, a estaca rompeu-se exatamente no final da armadura que possuía estribos, sendo que a extração total do fuste só foi conseguida devido à barra adicional de $12,5 \mathrm{~mm}$ colocada no centro da estaca. Para a estaca $\mathrm{E}_{2} \mathrm{a}$ extração foi possível sem provocar fissuras ao longo do fuste, tendo em vista que a armadura foi colocada até a ponta da estaca. No entanto a parte superior da estaca $E_{2}$ ficou com a armadura exposta sem o preenchimento com argamassa. A Figura 6.9 mostra a uma seqüência de imagens da extração da estaca $E_{2}$.

A impossibilidade de instalação das armaduras em todo o comprimento das estacas deveu-se à relação água cimento (a/c) igual a 0,50 adotada para a argamassa. Posteriormente esse valor foi alterado para 0,56, aumentando-se o consumo de cimento de $450 \mathrm{~kg} / \mathrm{m}^{3}$ para $470 \mathrm{~kg} / \mathrm{m}^{3}$ de argamassa. A relação água-cimento igual a 0,50 também resultou numa argamassa difícil de ser bombeada.

Outras estacas executadas com o novo traço de argamassa de cimento não apresentaram problemas de colocação das armaduras e o bombeamento ocorreu de maneira satisfatória. 

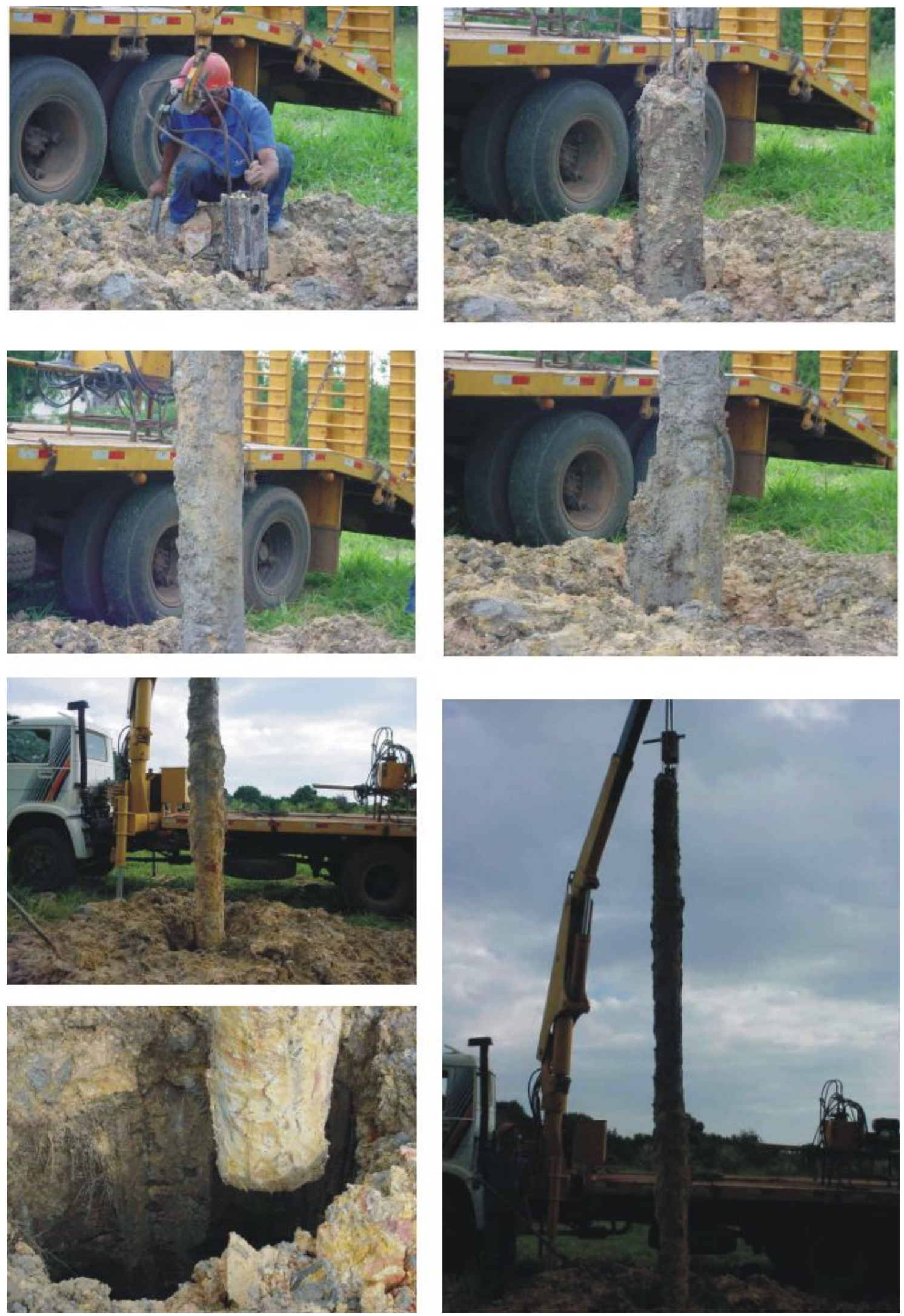

Figura 6.8 - Seqüência da extração da estaca $E_{1}$ com utilização de um guincho, após a escavação do solo circundante. 

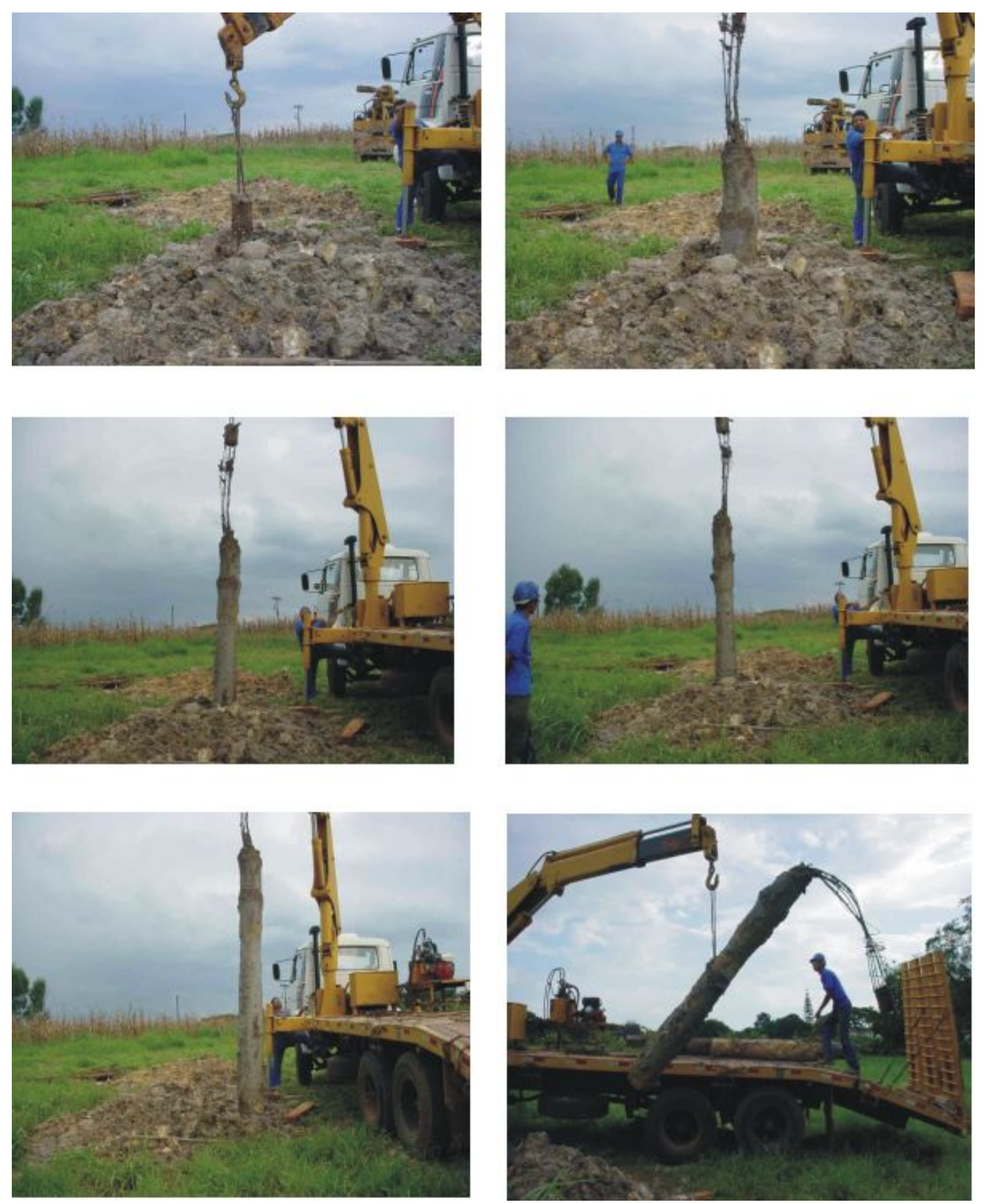

Figura 6.9 - Seqüência da extração da estaca $E_{2}$

Na Figura 6.10 a estaca $E_{2}$ encontra-se extraída e em fase de posicionamento na carroceria do caminhão. Mesmo com a concretagem parcial não foi possível realizar a extração com o guincho, sem executar as escavações no contorno da estaca. Pode-se observar o significativo aumento do fuste na parte inferior da estaca devido à aplicação de pressões de injeção da ordem $250 \mathrm{kPa}$ na região da ponta da estaca. 


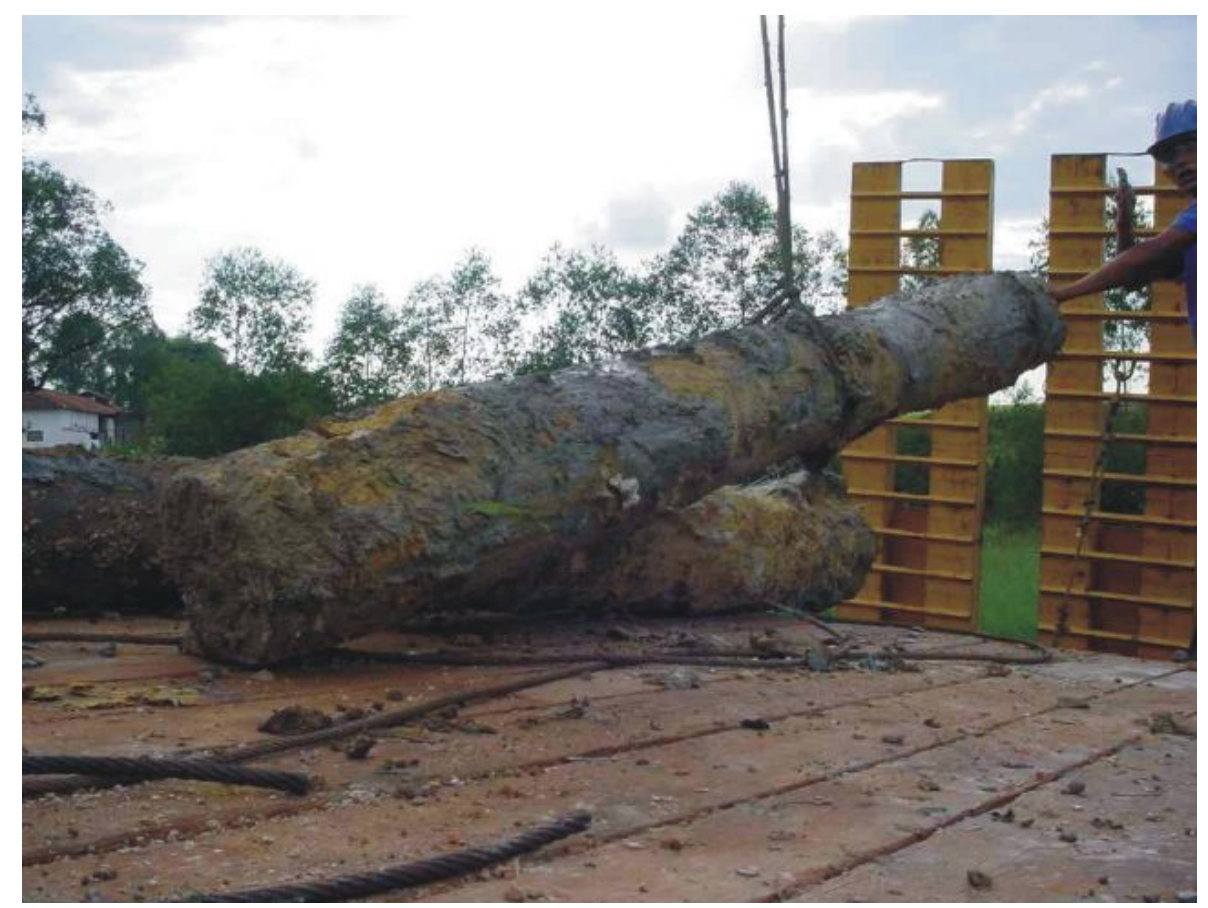

Figura 6.10 - Estaca E2 extraída e sendo colocada na carroceria do caminhão.

Após o transporte da estacas para um depósito, as mesmas foram lavadas e escovadas, o que possibilitou as seguintes constatações:

a) A integridade das estacas foi conseguida apenas com o monitoramento das pressões de injeção ao longo dos fustes.

b) Os aumentos nas seções transversais das estacas ocorreram devido à baixa resistência do terreno e à insistência do autor em conseguir pressões de injeção da ordem de $200 \mathrm{kPa}$ ao longo do fuste.

c) Houve um sobreconsumo de argamassa da ordem de $50 \%$.

d) Na ponta de cada estaca provavelmente formou-se um bulbo, devido às pressões de injeção da ordem de $250 \mathrm{kPa}$ e presença de solo que permitiu deformações nas direções perpendiculares ao eixo longitudinal da estaca. Esses bulbos romperam-se junto ao final das armaduras longitudinais durante a extração das estacas. Essa afirmação pôde ser feita após a observação da textura da argamassa nas seções transversais das pontas das estacas (Figuras 6.11 e 6.12$)$. 


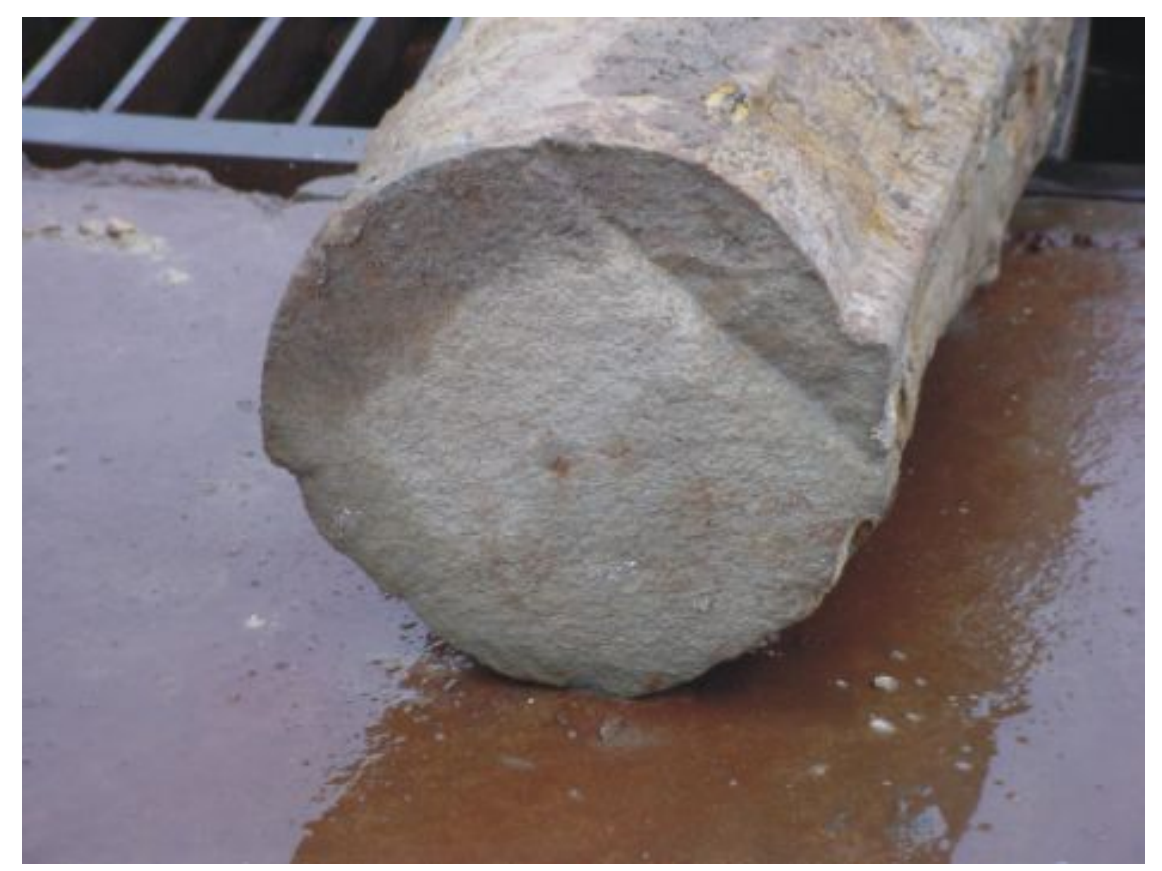

Figura 6.11 - Detalhe da ruptura ocorrida na ponta da estaca $E_{1}$.

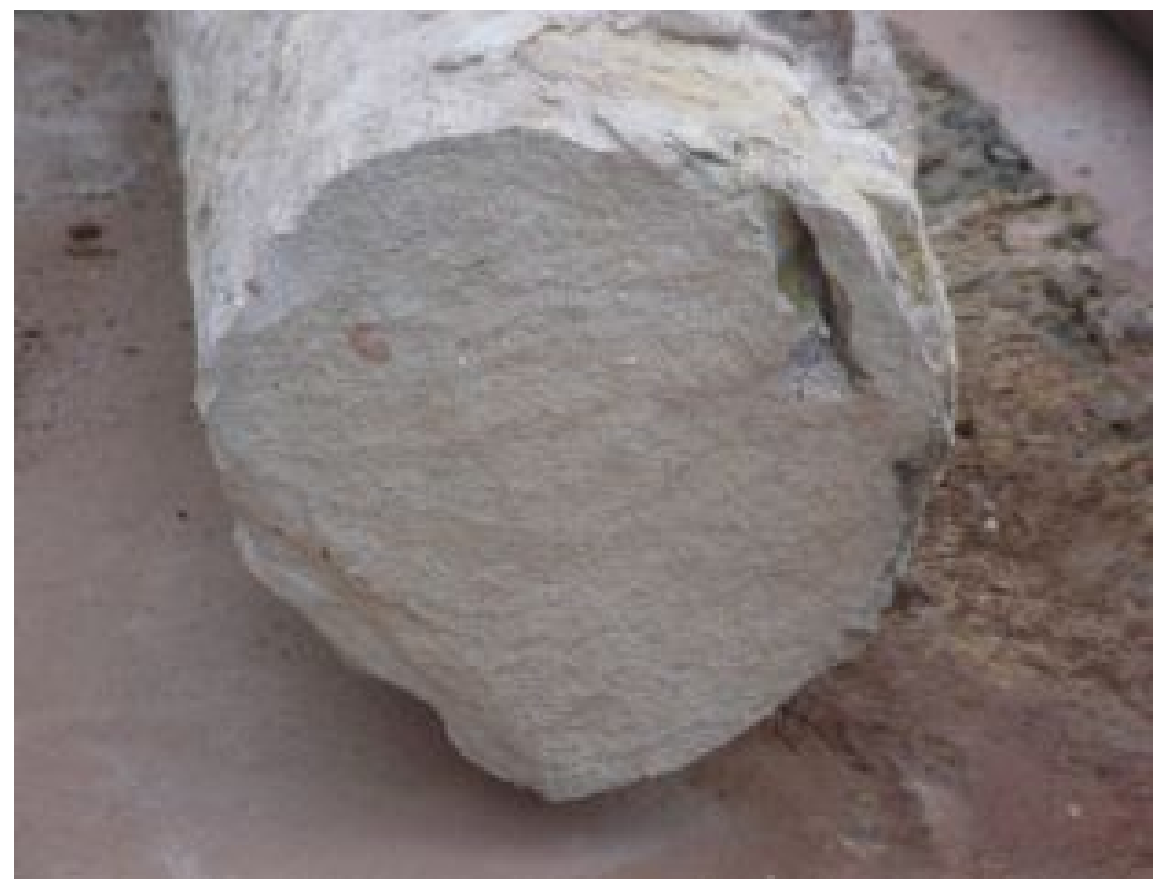

Figura 6.12 - Detalhe da ruptura ocorrida na ponta da estaca $E_{2}$. 


\section{CAPÍTULO 7}

\section{CONCLUSÕES E SUGESTÕES PARA OUTRAS PESQUISAS}

\subsection{CONCLUSÕES DA DISSERTAÇÃO.}

As principais conclusões da dissertação são:

a) A estaca hélice segmentada poderá ser uma opção viável em obras pequenas e médias, devido ao baixo custo quando comparada com outros tipos de estacas.

b) $\mathrm{O}$ menor peso do equipamento em relação aos equipamentos importados semelhantes, combinado ao sistema de autocarregamento viabilizam sua mobilização rápida e econômica, utilizando caminhões comuns com um eixo dianteiro e dois eixos traseiros, ou pranchas leves.

c) O monitoramento das pressões de injeção de argamassa utilizando-se um manômetro analógico mostrou-se eficiente nas duas estacas executadas, visto que as mesmas foram extraídas e apresentaram-se com fustes totalmente íntegros.

d) $\mathrm{O}$ monitoramento das pressões de injeção de argamassa utilizando-se um manômetro digital mostrou-se eficiente e mais prático que o analógico já que as leituras são feitas em um receptor instalado próximo ao operador.

e) A estaca hélice segmentada poderá representar uma alternativa interessante às estacas do tipo Strauss devido à grande vantagem na qualidade e com custos semelhantes.

f) A estaca hélice segmentada poderá tornar-se atrativa em obras onde as construções vizinhas possam sofrer danos devido à utilização de estaca de deslocamento.

g) Os equipamentos para estacas hélice segmentada poderão ser aperfeiçoados pelos brasileiros de forma a viabilizar exportações, além de diminuir as importações de equipamentos semelhantes, o que é interessante ao nosso país. 
h) A concepção do cabeçote rotativo que permite a execução de estacas próximas às divisas é interessante já que diminui a excentricidade da carga do pilar, possibilitando a utilização de vigas de equilíbrio com seções menores e menos armadura longitudinal, além de viabilizar a utilização do equipamento na execução de cortinas de contenção em divisas.

i) A utilização de argamassa de cimento mostrou-se interessante e econômico em obras com pequenas quantidades de estacas, já que não necessita da mobilização de caminhões betoneiras transportando pequenos volumes de concreto e locação de bombas de concreto.

j) A utilização de trados segmentados exige cuidado especial do operador no sentido de se manter, durante a fase de extração, uma coluna de argamassa no tubo central, com altura igual à distância da ponta da hélice até o nível da morsa hidráulica da perfuratriz. Essa coluna irá garantir a existência de pressão manométrica positiva (maior que zero), que é extremamente importante para a obtenção de fuste contínuo e integro. Caso essa condição não seja satisfeita poderá haver contaminação da argamassa pelo solo ou até mesmo o seccionamento do fuste da estaca.

k) A característica multifuncional do equipamento torna-o atratrivo já que pode ser utilizado para a execução de diversos tipos de fundações tais como: estaca escavada com trado mecânico, estaca do tipo "hollow-auger", tubulão mecanizado e estaca hélice segmentada.

\subsection{SUGESTÕES PARA OUTRAS PESQUISAS.}

a) Desenvolver pesquisas utilizando-se a perfuratriz, com o objetivo de reunir informações sobre o comportamento desse tipo de estaca sob diversas condições de carregamento, tais como: compressão, tração, flexão composta, cargas horizontais, etc.

b) Analisar a influência da execução de estacas hélice segmentada, com diferentes pressões de injeção, na capacidade de carga à compressão e à tração.

c) Executar provas de carga em estacas hélice segmentada comparando-se as resistências dos elementos isolados de fundação para estacas injetadas com argamassa e estacas injetadas com a utilização de concreto. 
d) Executar provas de carga em estacas do tipo hélice contínua e hélice segmentada comparando-se os resultados.

e) Desenvolver um equipamento com as seguintes implementações:

- Trados segmentados mais longos, que deverão resultar em aumento da produtividade da perfuratriz sem acréscimo significativo de custos.

- Cabine para o operador, com sistema adequado de iluminação e ventilação.

- Proteção do motor diesel para diminuição de ruídos.

- Prumo eletrônico para maior precisão no controle da verticalidade da escavação, durante o processo de escavação.

- Indicador eletrônico que forneça informações sobre as condições de estabilidade do equipamento em função das inclinações da torre em diversos planos, inclusive com emissão de sinal sonoro em casos limites de estabilidade. 


\section{REFERÊNCIAS BIBLIOGRAFICAS}

ABEF. (1999). Manual de Especificações de Produtos e Procedimentos. ABEF, São Paulo, 282p.

ABNT (1996). Projeto e execução de fundações. NBR 6122, Rio de Janeiro, 33p.

ABNT (2001). Sondagens de simples reconhecimento com SPT. NBR 6484, Rio de Janeiro, 17p.

ALONSO, U.R. (1993). Reavaliação do dimensionamento estrutural de estacas raiz face à exigência do ensaio MB-3472 da ABNT. Solos e Rochas, v.16, n.1, p.41-44.

ALTLAS COPCO (1999). Catálogo de Equipamentos de perfuração para geotecnia. Brasil, 6p.

ALBUQUERQUE, P.J.R.; MASSAD,F.; CARVALHO,D.; FERREIRA, M.A.M. (2001). Comportamento à Compressão de Estacas Escavadas, Hélice Contínua e Hélice tipo Omega, em solo Residual de Diabásio. UNICAMP- Parceria com EPUSP, FAPESP, CNPQ, ABMS, FUNDESP, 198p.

BAUER MASCHINEM GmbH (2003). Catálogo de produtos. Alemanha, 20p.

BAUER MASCHINEM GmbH (2003). Folheto de apresentação de equipamentos e acessórios de perfuração. Alemanha, 4p.

BAUER MASCHINEM GmbH (2003). Folheto de apresentação de algumas obras executadas com utilização dos equipamentos fabricados pela empresa. Alemanha, 6p.

BERETTA ALFREDO s.r.l. (199_?). Catálogo da perfuratriz T 45. Itália, 2p.

BERETTA ALFREDO s.r.l. (199_?). Catálogo da perfuratriz T 50. Itália, 6p.

BRASFOND FUNDAÇÕES ESPECIAIS S.A. (2001). Catálogo de apresentação da empresa, equipamentos e obras. Guarulhos-SP, 54p.

B.S. TUBOS E BOMBAS LTDA (200-?). Catálogo geral de diversos equipamentos e ferramentas. Betim-MG, 4p.

B.S. TUBOS E BOMBAS LTDA (200-?). Catálogo da perfuratriz BS 1200, 2p.

CHUGH, C.P. (1985). Manual of Drilling Technology. A.A.Balkema/Rotterdam, 1985. 567p. 
CLÓ ZIRONI ORGANIZAÇÕES LTDA. (2002). Catálogo do equipamento CD12. Belo Horizonte -MG, 5p.

CLÓ ZIRONI ORGANIZAÇÕES LTDA. (2001). Catálogo do equipamento CFA60. Belo Horizonte -MG, 4p.

CLÓ ZIRONI ORGANIZAÇÕES LTDA. (200-?). Catálogo do equipamento CA80. Belo Horizonte -MG, 4p.

CLÓ ZIRONI ORGANIZAÇÕES LTDA. (200-?). Catálogo do equipamento CR18. Belo Horizonte -MG, 2p.

CLÓ ZIRONI ORGANIZAÇÕES LTDA. (200-?). Catálogo do equipamento CD30. Belo Horizonte-MG, 6p.

CLÓ ZIRONI ORGANIZAÇÕES LTDA. (199-?). Catálogo da perfuratriz CD17. Belo Horizonte -MG, 2p.

CLÓ ZIRONI ORGANIZAÇÕES LTDA. (199-?). Catálogo de diversos equipamentos. Belo Horizonte-MG, 4p.

CLÓ ZIRONI ORGANIZAÇÕES LTDA. (200-?). Catálogo da perfuratriz CA40. Belo Horizonte-MG, 4p.

CLÓ ZIRONI ORGANIZAÇÕES LTDA.(199-?). Catálogo da perfuratriz CL07. Belo Horizonte-MG, 2p.

CLÓ ZIRONI ORGANIZAÇÕES LTDA.(199-?). Catálogo de perfuratriz CD20. Belo Horizonte-MG, 4p.

CLÓ ZIRONI ORGANIZAÇÕES LTDA.(198-?). Catálogo de perfuratriz CD27. Belo Horizonte-MG, 2p.

CLÓ ZIRONI ORGANIZAÇÕES LTDA. (2002). Catálogo de perfuratriz CD20-P; CD20-PR. Belo Horizonte-MG, 4p.

CLÓ ZIRONI ORGANIZAÇÕES LTDA. (200-?). Catálogo de perfuratriz montada em chasi CA60. Belo Horizonte-MG, 2p.

CLÓ ZIRONI ORGANIZAÇÕES LTDA. (200-?). Catálogo de perfuratriz rotativa sobre guindaste CZ80 A-1 \& CZ80 A-2. Belo Horizonte-MG, 3p.

CLÓ ZIRONI ORGANIZAÇÕES LTDA. (200-?) Catálogo de perfuratriz hidráulica sobre caminhão CD30-R. Belo Horizonte-MG, 2p.

CLÓ ZIRONI ORGANIZAÇÕES LTDA. (200-?). Catálogo de perfuratriz rotativa hidráulica CA42. Belo Horizonte-MG, 1p 
CLÓ ZIRONI ORGANIZAÇÕES LTDA (200-?). Drilling Rigs Perforadoras. Belo Horizonte-MG, 2p.

CMV GROUP (200-?). Hydraulic Piling Rig. Catálogo de equipamentos TH10/25. Itália, 6p.

CMV GROUP (200-?). Hydraulic Piling Rig. Catálogo de equipamentos TH10/30. Itália, 6p.

CMV GROUP (200-?). Hydraulic Piling Rig. Catálogo de equipamentos TH14/35. Itália, 6p.

CMV GROUP (200-?). Hydraulic Piling Rig. Catálogo de equipamentos TH16/50. Itália, 6p.

CMV GROUP (200-?). Hydraulic Piling Rig. Catálogo de equipamentos TH18/75. Itália, 6p.

CMV GROUP (200-?). Hydraulic Piling Rig. Catálogo de equipamentos TH22/75. Itália, 6p.

EGTECHNOLOGY (200-?). Folheto representativo de desenho da perfuratriz VD500 CFA. Parma, Itália. 2p.

EGTECHNOLOGY (200-?). Folheto de desenho e especificações da perfuratriz VD500 CFA. Parma, Itália. 2p.

EGTECHNOLOGY (200-?). Catálogo do equipamento HULTIPOPOSE DRILL. Parma, Itália, 4p.

EGTECHNOLOGY SRL. (200-?). Catálogo de equipamento VD500 CFA. Itália, 3p.

E.G.BARRETO. (1987). Foto da perfuratriz modelo M 500. 1 fotografia, color; $10 \mathrm{~cm} \mathrm{x}$ $15 \mathrm{~cm}$. Brasil.

E.G.BARRETO. (1993). Foto da perfuratriz modelo H 800. 1 fotografia, color; $10 \mathrm{~cm} \mathrm{x}$ $15 \mathrm{~cm}$. Brasil.

E.G.BARRETO. (1994). Foto da perfuratriz modelo H 800. 1 fotografia, color; $10 \mathrm{~cm} \mathrm{x}$ $15 \mathrm{~cm}$. Brasil.

E.G.BARRETO. (199-?). Foto da perfuratriz modelo H 1000. 1 fotografia, color; $10 \mathrm{~cm}$ $\mathrm{x} 15 \mathrm{~cm}$. Brasil.

E.G.BARRETO. (1995). Foto do início da obra da cervejaria KAISER na cidade de Araraquara. 1 fotografia, color; $10 \mathrm{~cm} \mathrm{x} 15 \mathrm{~cm}$. Brasil.

E.G.BARRETO. (1996). Foto do término da obra da cervejaria KAISER na cidade de Araraquara. 1 fotografia, color; $10 \mathrm{~cm} \mathrm{x} 15 \mathrm{~cm}$. Brasil. 
E.G.BARRETO. (1996). Foto da perfuratriz modelo MH 500. 1 fotografia, color; $10 \mathrm{~cm}$ $\mathrm{x} 15 \mathrm{~cm}$. Brasil.

E.G.BARRETO. (1997). Foto da perfuratriz modelo HT 710.1 fotografia, color; $10 \mathrm{~cm}$ x $15 \mathrm{~cm}$. Brasil.

E.G.BARRETO. (1997). Foto da perfuratriz modelo HC 9 18. 1 fotografia, color; $10 \mathrm{~cm}$ x $15 \mathrm{~cm}$. Brasil.

E.G.BARRETO. (1999). Foto da perfuratriz modelo HC 920.1 fotografia, color; $10 \mathrm{~cm}$ $\mathrm{x} 15 \mathrm{~cm}$. Brasil.

E.G.BARRETO. (1999). Foto da perfuratriz modelo HT 9 16. 1 fotografia, color; $10 \mathrm{~cm}$ x $15 \mathrm{~cm}$. Brasil.

E.G.BARRETO. (2001). Foto da perfuratriz modelo HC 9 16. 1 fotografia, color; $10 \mathrm{~cm}$ x $15 \mathrm{~cm}$. Brasil.

E.G.BARRETO. (2003). Foto da perfuratriz modelo HT 18 22A. Execução de estacas escavadas com utilização de trado oco "Hollow-Auger".1 fotografia, color; $10 \mathrm{~cm} \mathrm{x} 15$ $\mathrm{cm}$. Brasil.

EMDE INDUSTRIE - TECHNIK (2001). Catálogo de ferramentas de perfuração. Alemanha, 8p.

FUNDESP- Fundações Especiais Ltda. (2001). Apresentação da Empresa, equipamentos e obras. Jandira-SP, Brasil, 62p.

HACHICH, W; FALCONI, F.F; SAES, J.L.; FROTA, R.G.Q; CARVALHO, C.S.; NIYAMA, S. (1996). Fundações Teoria e Prática. ABMS/ABEF/PINI. (1996), capitulo 08 p.265.

HARTIKAINEN, J; GAMBIM, M.P. Deep fonundations with soil escavation: bored piles, root piles, CFA piles, slurry trench walls. In: Pile and Deep foundations. $4^{\text {th }}$ International conference. 1991. Stresa - Italy. Proceeding... Stresa, 1991, v2.

HUGH WILLIAMS (1988). Catálogo das perfuratrizes modelos EZ210, EZ216, EZ218 e EZ230, montadas sobre caminhão. Virginia - USA, 4p.

HUGH WILLIAMS (1988). Catálogo de ferramentas de perfuração. Virginia - USA, $12 \mathrm{p}$.

I.M.T. Industria Meccanica Trivelle (1995). Catálogo do equipamento AF12. Itália, 8p.

I.M.T. Industria Meccanica Trivelle (1995). Catálogo do equipamento AF16. Itália, 4p.

I.M.T. Industria Meccanica Trivelle (1995). Catálogo do equipamento IMT AF10 Drilling Rig. Itália, 16p.

IMT. (199- ). Catálogo das Perfuratrizes AF6, AF12 e AF16. Itália, 24p. 
JEAN LUTZ S.A.(200- ). Catálogo de equipamentos. França, 4p.

JUNTTAN (2001). Catálogo de apresentação de produtos. Finlândia, 8p.

MAIT S.p. A Macchine Industriali Trivellatrici (200- ). Catálogo de Produtos Fabricados pela empresa. Itália, 16p.

MAIT S.p. A Drilling Rigs (1998). Catalogo do equipamento HR240. Itália, 2p.

MAIT S.p. A Drilling Rigs (1998). Catálogo do equipamento HR200. Itália, 2p.

MAIT S.p. A Drilling Rigs (1998). Catálogo do equipamento HR160. Itália, 2p.

MAIT S.p. A Drilling Rigs (1998). Catálogo do equipamento HR130. Itália, 2p.

MAIT S.p. A Drilling Rigs (1998). Catálogo do equipamento HR110. Itália, 2p.

MAIT S.p. A Drilling Rigs (1998). Catálogo do equipamento HR45. Itália, 2p.

MAIT S.p. A Drilling Rigs (1998). Catálogo do equipamento EB12. Itália, 2p.

MAIT S.p. A Drilling Rigs (1998). Catálogo do equipamento CFA24. Itália, 2p.

MAPER s.r.l. (200_?). Catálogo de ferramentas de perfuração. Itália, 6p.

MORI s.r.l. (200_?). Catálogo da perfuratriz M 60. Itália, 4p.

NR 18. (1978). Condições e Meio Ambiente de Trabalho na Indústria da Construção. Portaria 3214 de 8 de Julho de 1978. Ministério do Trabalho.

PALMIERI, A.C. (1985). Manual de hidráulica básica. Racine Hidráulica Ltda. 5.ed. Porto Alegre. p.77-129, p.293-294.

PENNA, A.S.D.; CAPUTO, A.N.; MAIA, C.M.; PALERMO, G.; GOTLIEB, M; PARAÍSO, S.C.; ALONSO, R,U. (1999). Estaca Hélice - Contínua A Experiência Atual. ABMS/ABEF. São Paulo, 162p.

REXTROTH HIDRÁULICA LTDA. (1988). Catálogo geral. São Paulo, p.B4.

SEGOVIA s.l. (200_?). Folheto de equipmento e acessórios para perfuração. Espanha, 2 p.

SOILMEC Drilling and Foundation equipment. (1995). Catálogo do equipamento R-208. Italia, 4p.

SOILMEC Drilling and Foundation equipment. (1995). Catálogo do equipamento CM-48. Italia, 8p.

SOILMEC Drilling and Foundation equipment. (1995). Catálogo do equipamento 
R-622. Italia, 4p.

TOMLINSON, M.J. (1994). Pile Design and Construction Practice.E \& FN Spon. p. 7- 97.

VELLOSO, D.A.; LOPES, F.R. (2002). Fundações. COPPE-UFRJ.,v2. Rio de Janeiro, p.1- 69 .

VAN IMPE, W.F. (1998). Deep Foundations on Bored and Auger Piles. Proceedings of the International Geotechnical Seminar on Deep Foundations on Bored and Auger Piles, $3^{\text {nd }}$, Ghent-Belgium. Proceeding... Rotterdam: A.A.Balkema, 1998. 524p.

WIRTH LATINA S.A. (19--?). Catálogo de perfuratrizes e ferramentas. São Carlos, 12p.

WIRTH MASCHINEN. (2003). Catálogo da série de perfuratrizes ECODRILL 40. Alemanha, 6p. 